\title{
The Myth of
}

Piers Plowman

Constructing a

Medieval Literary Archive

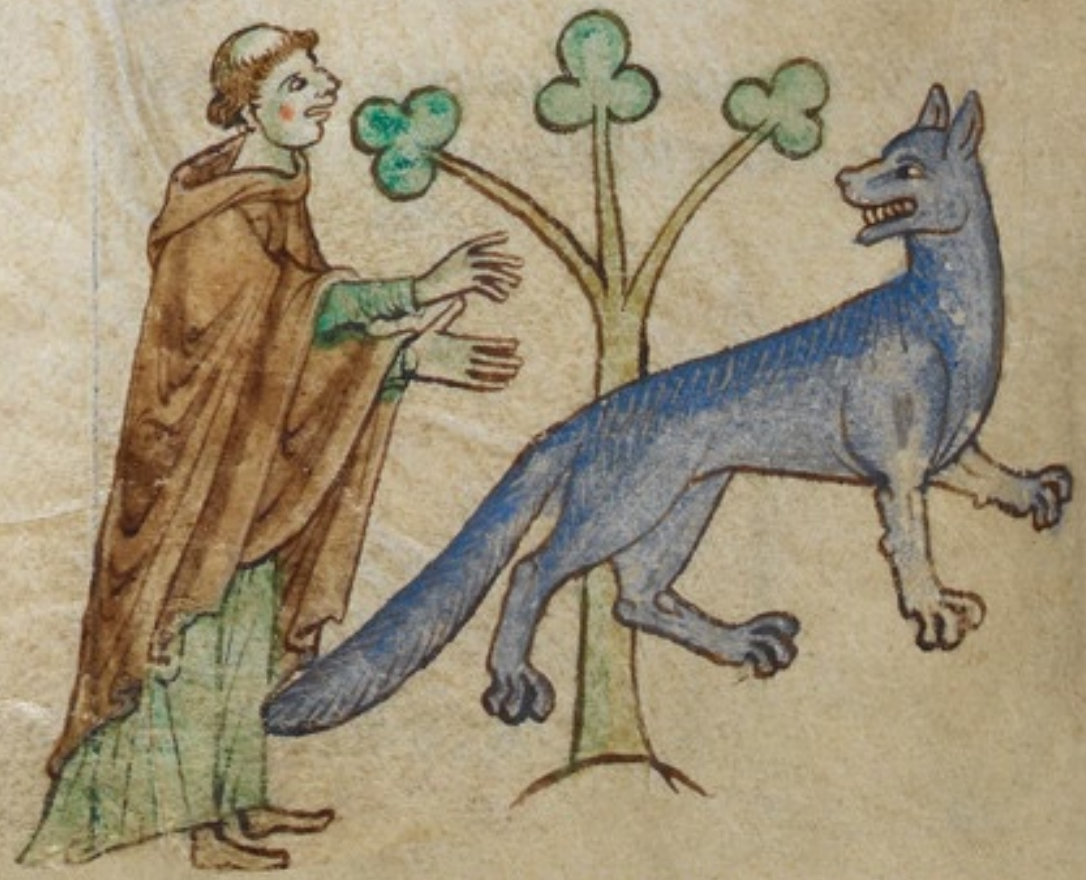

LAWRENCE WARNER 



\section{THE MYTH OF PIERS PLOWMAN}

Addressing the history of the production and reception of the great medieval poem, Piers Plowman, Lawrence Warner reveals the many ways in which scholars, editors, and critics over the centuries created their own speculative narratives about the poem, which gradually came to be regarded as factually true. Warner begins by considering the possibility that Langland wrote a romance about a werewolf and bear-suited lovers, and goes on to explore the methods of the poem's localization, and medieval readers' particular interest in its Latinity. Warner shows that the "Protestant Piers" was a reaction against the poem's oral mode of transmission, reveals the extensive eighteenth-century textual scholarship on the poem by figures including the maligned Chaucer editor John Urry, and contextualizes its first modernization by a literary forger inspired by the I790 Shakespeare controversies. This lively account of Piers Plowman challenges the way the poem has traditionally been read and understood.

LAWRENCE WARNER is Senior Lecturer in Medieval English at King's College London and Director of the International Piers Plowman Society. His book, The Lost History of Piers Plowman: The Earliest Transmission of Langland's Work (2OII), received Honorable Mention for the 2013 Richard J. Finneran Award of the Society for Textual Scholarship. 


\title{
CAMBRIDGE STUDIES IN MEDIEVAL LITERATURE
}

\author{
GENERAL EDITOR \\ Alastair Minnis, Yale University \\ EDITORIAL BOARD \\ Zygmunt G. Barański, University of Cambridge \\ Christopher C. Baswell, Barnard College and Columbia University \\ John Burrow, University of Bristol \\ Mary Carruthers, New York University \\ Rita Copeland, University of Pennsylvania \\ Roberta Frank, Yale University \\ Simon Gaunt, King's College London \\ Steven Kruger, City University of New York \\ Nigel Palmer, University of Oxford \\ Winthrop Wetherbee, Cornell University \\ Jocelyn Wogan-Browne, Fordham University
}

This series of critical books seeks to cover the whole area of literature written in the major medieval languages - the main European vernaculars, and medieval Latin and Greek - during the period c.IIOO-I5OO. Its chief aim is to publish and stimulate fresh scholarship and criticism on medieval literature, special emphasis being placed on understanding major works of poetry, prose, and drama in relation to the contemporary culture and learning which fostered them.

RECENT TITLES IN THE SERIES

Antony J. Hasler

Court Poetry in Late Medieval England and Scotland: Allegories of Authority

Shannon Gayk

Image, Text, and Religious Reform in Fifteenth-Century England

Lisa H. Cooper

Artisans and Narrative Craft in Late-Medieval England

Alison Cornish

Vernacular Translation in Dante's Italy: Illiterate Literature

Jane Gilbert

Living Death in Medieval French and English Literature

Jessica Rosenfeld

Ethics and Enjoyment in Late Medieval Poetry: Love after Aristotle

Michael Van Dussen

From England to Bohemia: Heresy and Communication in the Later Middle Ages Martin Eisner

Boccaccio and the Invention of Italian Literature: Dante, Petrarch, Cavalcanti, and the Authority of the Vernacular

Emily V. Thornbury

Becoming a Poet in Anglo-Saxon England

A complete list of titles in the series can be found at the end of the volume. 


\title{
THE MYTH OF PIERS PLOWMAN
}

Constructing a Medieval Literary Archive

\author{
LAWRENCE WARNER
}




\section{CAMBRIDGE \\ UNIVERSITY PRESS}

University Printing House, Cambridge Св2 8BS, United Kingdom

Published in the United States of America by Cambridge University Press, New York

Cambridge University Press is part of the University of Cambridge.

It furthers the University's mission by disseminating knowledge in the pursuit of education, learning and research at the highest international levels of excellence.

\section{www.cambridge.org \\ Information on this title: www.cambridge.org/9781107043633}

(C) Lawrence Warner 2014

This version is published under a Creative Commons Attribution-No Derivatives licence.

This licence allows the content to be redistributed, as commercial or non-commercial products, as long as it is unchanged and the entire content, and attribution credited to the original.

To view a copy of this licence, visit http://creativecommons.org/licenses/by-nd/3.o/.

First published 2014

Printed in the United Kingdom by Clays, St Ives plc

A catalogue record for this publication is available from the British Library

Library of Congress Cataloguing in Publication data

Warner, Lawrence, I968-

The myth of Piers Plowman : constructing a medieval literary archive / Lawrence Warner. pages $\mathrm{cm} .-$ (Cambridge studies in medieval literature ; 89)

$$
\text { ISBN 978-I-IO7-04363-3 (Hardback) }
$$

I. Langland, William, I330?-I400?-Criticism and interpretation. 2. Langland, William, I330?-I400?-Authorship. 3. Langland, William, I330?-I400? Piers Plowman-

Criticism, Textual. I. Title.

PR2OI5.W37 2014

$$
82 \mathrm{I}^{\prime} . \mathrm{I}-\mathrm{dc2} 32 \mathrm{OI} 3033226
$$

ISBN 978-I-I07-04363-3 Hardback

Cambridge University Press has no responsibility for the persistence or accuracy of URLs for external or third-party internet websites referred to in this publication, and does not guarantee that any content on such websites is, or will remain, accurate or appropriate. 
For my father, Seth L. Warner, and in memory of my mother, Emily Rose Warner 



\section{Contents}

List of figures

page viii

Acknowledgments

List of abbreviations xiii

A note on citations xiv

Introduction: archive fever and the madness of Joseph Ritson I

I William and the werewolf: the problem of William of Palerne 22

2 Localizing Piers Plowman C: Meed, Corfe castle, and the London Riot of 1384

3 Latinitas et communitas Visionis Willielmi de Langlond 53

4 "Quod piers plowman": non-reformist prophecy, c.1520-1555 72

5 Urry, Burrell, and the pains of John Taylor: the Spelman MS, I709-1766 87

6 William Dupré, fabricateur: Piers Plowman in the age of forgery, $c .1794-\mathrm{I} 802 \quad 106$

Conclusion: Leland's madness and the tale of Piers Plowman I29

Notes

Bibliography $\quad 187$

Index of manuscripts, early printed books, annotated books, and portraits

General index 


\section{Figures}

I Ritson's list of difficult words and "memorable particulars." Lehigh University Library 82I.I L265p I550 [Endmatter 4]. Special Collections, Lehigh University Libraries, Bethlehem, Pennsylvania, USA.

2 Ritson's transcription of Harley 3954's final lines. Lehigh University Library 82I.I L265p I550 [Endmatter 6].

Special Collections, Lehigh University Libraries, Bethlehem, Pennsylvania, USA.

3 Lines of transmission of the two C-text MS families.

4 Latin lines following on from the MS's Piers Plowman. Oxford, Bodleian MS Ashmole I468, p. 378.

5 Latin lines from Piers Plowman transcribed in a Crowley. New Haven, Beinecke Rare Book and Manuscript Library, Yale University, ID L 26 550c, sig. $4^{\mathrm{v}}$.

6 "Two monks' heads" prophecy in The Winchester Anthology. London, British Library, Additional MS 60577, fol. $212^{\mathrm{r}}$.

(C) The British Library Board, ADD 60577 f2I2r.

7 Ownership inscription in The Winchester Anthology. London, British Library, Additional MS 60577, end pastedown.

(C) The British Library Board, ADD 60577 (back inside).

8 Another "Davy the dykar" poem. London, British Library, MS Sloane 2578, fol. $27^{\mathrm{r}}$. (C) The British Library Board, Sloane $2578 \mathrm{f} 27 \mathrm{r}$.

9 Ownership inscriptions at the opening of Piers Plowman. San Marino, Huntington Library, MS Hm II4, fol. $\mathrm{I}^{\mathrm{r}}$. This item is reproduced by permission of The Huntington Library, San Marino, California.

IO Urry's reference to the Spelman MS in his transcription of Crowley's preface. Oxford, Balliol College 525.a.I, verso of title page. 
II Urry's comparison of Piers Plowman to Homer. Oxford, Balliol College 525.a.I, sig. B.ii ${ }^{\mathrm{v}}$.

I2 Burrell's collations of Cr with the Spelman and Harley MSS. Oxford, Bodleian Library $4^{\circ}$ Rawlinson 272 , sig. I.iv ${ }^{r}$.

I3 Burrell's transcription of $\mathrm{C}_{5}$.I-27 (omitting 2I) from the Spelman MS. Oxford, Bodleian Library $4^{\circ}$ Rawlinson 272, flyleaf after sig. E.iv .

I4 Vertue's engraving, taken from the Chandos portrait. London, National Portrait Gallery, NPG D25488. (C) National Portrait Gallery, London.

I5 From Duprés modernization of Piers Plowman. Oxford, Bodleian Library MS Douce 323, fol. iv.

I6 Douce's notes on Dupré and the pilgrim. Oxford, Bodleian Library MS Douce IO4, opening at fols. $33 \mathrm{a}^{\mathrm{v}}-33 \mathrm{~b}^{\mathrm{r}}$. 


\section{Acknowledgments}

I begin by acknowledging three scholars I have met or corresponded with only in passing, but who in effect created the field to which this book contributes, and who, if I might wear my hat as Director of the International Piers Plowman Society for a moment, deserve the deepest gratitude of the Langland community: John Alford, Vincent DiMarco, and Charlotte Brewer. The smallest of their contributions to this book were Professor Alford's invitation for me to be respondent to the Piers Plowman Electronic Archive panel at the 1999 Asheville Langland conference, which changed my life; Professor DiMarco's characteristically cheerful help regarding a small bibliographical problem; and Dr. Brewer's generous responses to queries about, and provision of copies of, the editorial work on the poem in London in the I920s.

Among those who responded to portions of this book in draft form, I am especially grateful to Emily Steiner, who read all of it just as she was completing Reading Piers Plowman. That is true dedication, and her deep knowledge of the poem, and ear for tone the equal of Brian Wilson's, helped me improve it greatly. Others who provided generous feedback on portions of this book are A. S. G. Edwards, David Matthews, R. Carter Hailey (scholar and gentleman, who in many ways inspired me to undertake the second half of this book), and Simon Horobin, who also provided hospitality at Magdalen College and the University of Oxford, and urged me to continue looking into the identity of "Mr. Dupré" even after he had independently made his own initial inquiries. Over the years I have presented much of this material at conferences and seminars, and would like to acknowledge in particular, for their rigorous feedback and conversation, the audiences of the Piers Plowman Electronic Archive Seminar, Los Angeles, 2009; the London Old and Middle English Research Seminar, March 20II (thanks to Ruth Kennedy and Cath Nall); and the Fifth International Piers Plowman Society conference, Oxford, April 20II. 
For helping me figure out who all the people who populate this book were, and what they were writing, annotating, printing, and doing, thanks to a pleasingly diverse body of scholars: Michael J. Bennett, Tekla Bude, Megan Cook, Rebecca Davis, John H. Farrant, Alexandra Gillespie, Michael Johnston, Eileen Joy, Sarah Kelen, Paul Patterson, Tom Prendergast, Macklin Smith, and Neil Vickers. Let me single out Ian Cornelius, who consulted all the Crowley and Rogers copies at Harvard and Yale on my behalf, and alerted me to Latin interests of one owner. And, again, Andrew Cole and Fiona Somerset have been the truest and best of Langland friends, both as co-editors of $Y L S$ and as wicked smart advisors and founts of learning.

I am happy to record my thanks to the archivists and librarians who provided access to, images of, and advice about the many manuscripts and early printed books that feature here, in particular the staffs of: Balliol College Library, Oxford, especially Jeremy Hinchliff and Seamus Perry; the Beinecke Library of Yale University; the Bodleian Library, Oxford; the British Library, especially Bevan Blanchard and Giles Mandelbrote; the Huntington Library, San Marino, especially Mary Robertson; Lehigh University Library, Pennsylvania, especially Lois Black and Ilhan Citak; and the National Portrait Gallery, London, especially Matthew Bailey; all of whom kindly granted permission to reproduce materials from their collections. I also quote from or refer to materials from other libraries: thanks to Magill Library, Haverford College, Pennsylvania, especially Ann Upton; the University of Michigan Library, especially Peggy Daub and Sarah Rentz; and the State Library of Victoria, Melbourne, especially Jan McDonald. Two owners of Crowley editions, Professor Toshi Takamiya and the collector who now owns the copy inscribed by Alexander Pope and Thomas Warton, were generous in sharing information.

The University of Sydney Faculty of Arts and Department of English provided research support and study leave in 20II, during which much of this book came together. I am especially grateful to Will Christie and Paul Giles, and, for advice and friendship, to all my colleagues there and across Australia, especially Dan Anlezark, Geraldine Barnes, Mark Byron, Margaret Clunies Ross, Louise D’Arcens, Stephanie Downes, Huw Griffiths, Nick Riemer, the force of life called Stephanie Trigg, and Andrea Williams. I acknowledge the Menzies Centre for Australian Studies for awarding me an Australian Bicentennial Fellowship, which I spent at the English Department at King's College London, spring 20II. Clare Lees, not for the first time, was a wonderfully supportive mentor at King's; she joined Chair of Department Jo McDonagh, Sarah Salih, and Beatrice 
Wilford in making me feel most welcome - so welcome that I returned permanently in 2013. I acknowledge the Department of English and the School of Arts and Humanities of King's for providing support of the production costs of this book. Among my new London colleagues I would like to thank Isabel Davis and Alfred Hiatt in particular for their friendship.

Linda Bree, Anna Bond, Fiona Sewell, and Vania Cunha have been exemplary editors at Cambridge University Press, where, happily, my distant cousin and close friend Lynn Hieatt worked so long and well. I am also grateful to series general editor Alistair Minnis and to the two anonymous readers whose trenchant feedback was very helpful.

A portion of the Introduction originally appeared in The La Trobe Journal, published by the State Library of Victoria Foundation; I am grateful to its editor John Arnold. Chapters I and 4 are heavily revised versions of essays originally published in Viator and The Yearbook of Langland Studies. Thanks to Simon Forde and Guy Carney of Brepols; Andy Kelly and Blair Sullivan of the UCLA Center for Medieval and Renaissance Studies; and the anonymous readers of those earlier chapters (two of whom, John M. Bowers on Langland and William of Palerne and R. Carter Hailey on the sixteenth-century Piers Plowman, identified themselves). Much of the Conclusion was published in The Chaucer Review 48.I (20I3): II3-28; I am grateful to the Pennsylvania State University Press for permission to reproduce it here.

Janice Marjoribanks and the late Kevin Marjoribanks have been unstintingly supportive. I am in awe of Jan's willingness to go along for the ride. My beautiful wife Genevieve and delightful children Sebastian and Eloise: I will always think of this as our London book, which we all lived together, and laughed about, from our Islington headquarters, waiting for a taxi to take us to the London Eye and to the rest of the world. (Sebastian, there are plenty of candidates in here for you to dress up as next Book Day. I'd go with the werewolf.) I love you forever. Finally, my deepest thanks go to my parents, Seth L Warner and the late Emily Rose Warner, for the enduring example, love, and support they have always provided. One of my cherished possessions is the copy of the hardback Riverside Chaucer they gave me to commemorate Kalamazoo, 1990: an early sign that they would not mind seeing where this obsession with Middle English might take me. This book, which I dedicate to them, is a small way to repay them for everything. 


\section{Abbreviations}

\begin{tabular}{|c|c|}
\hline BL & British Library \\
\hline$B P$ & Joseph Ritson’s Bibliographia Poetica \\
\hline $\mathrm{Cr}^{\mathrm{I}}, \mathrm{Cr}^{2}, \mathrm{Cr}^{3}$ & $\begin{array}{l}\text { Robert Crowley's first, second, and third editions of } \\
\text { The Vision of Pierce Plowman }\end{array}$ \\
\hline CUL & Cambridge University Library \\
\hline EETS & Early English Text Society \\
\hline ELH & English Literary History \\
\hline$J E G P$ & Journal of English and Germanic Philology \\
\hline$M A E$ & Medium Avum \\
\hline$M P$ & Modern Philology \\
\hline$N \mathscr{H Q}$ & Notes \& Queries \\
\hline$O D N B$ & Oxford Dictionary of National Biography \\
\hline$P M L A$ & $\begin{array}{l}\text { Publications of the Modern Language Association of } \\
\text { America }\end{array}$ \\
\hline PPEA & Piers Plowman Electronic Archive \\
\hline RES & Review of English Studies \\
\hline$Y L S$ & Yearbook of Langland Studies \\
\hline
\end{tabular}




\section{$A$ note on citations}

In citing Middle English and Latin, I standardize $\mathrm{i} / \mathrm{j}$ and $\mathrm{u} / \mathrm{v}$ and sometimes silently depart from editorial punctuation. For sixteenth-century texts, I alter "ye" (i.e., thorn and e) to "the" silently, but for eighteenthcentury texts I leave it as is. Quotations from editions of Piers Plowman are presented in what seems most likely to be its poet's language: those from $\mathrm{C}$ are from George Russell and George Kane, eds., Piers Plowman: The $C$ Version (London: Athlone Press, 1997); those from A and B adopt the substantive readings and follow the line numbering of George Kane, ed., Piers Plowman: The A Version, rev. edn. (London: Athlone Press, 1988), and George Kane and E. Talbot Donaldson, eds., Piers Plowman: The B Version, rev. edn. (London: Athlone Press, 1988), but present the language in the form of the text of the $\mathrm{C}$ edition. I do not reproduce editorial brackets. See my discussion in The Lost History of Piers Plowman: The Earliest Transmission of Langland's Work (Philadelphia: University of Pennsylvania Press, 20II), xv-xvii. 


\section{Introduction: archive fever and the madness of Joseph Ritson}

"We will always wonder what, in this mal d'archive, he may have burned": thus, in remarking on the effects of Freud's "archive fever," does Jacques Derrida speak to the dilemma inherent in literary scholars' relationship with the concept of the archive. Freud was "burning with the desire to know, to make known, and to archive the very thing he concealed forever": the archive is both the repository of those remnants of the past from which history can be written and an indelible reminder, precisely on account of its selectivity, of how much must be excluded, burned, if it is to exist at all. ${ }^{1}$ Derrida points out that "the meaning of 'archive,' its only meaning, comes to it from the Greek arkheion: initially a house, a domicile, an address, the residence of the superior magistrates, the archons, those who commanded," but that home is not open to all: "The archons are first of all the documents' guardians. They do not only ensure the physical security of what is deposited and of the substrate. They are also accorded the hermeneutic right and competence."

A pertinent question for modern literary scholars, says David Greetham, is whom we are to recognize as those Derrida calls the archons. ${ }^{3}$ Its pertinence derives in large part from the fact that the work of these guardians is the foundation for any concept of the author, on which so much literary research is still based. Michel Foucault famously pushed the question to the limit by imagining a limitless authorial archive: "But what if, in a notebook filled with aphorisms, we find a reference, a reminder of an appointment, an address, or a laundry bill, should this be included in his works? Why not? These practical considerations are endless once we consider how a work can be extracted from the millions of traces left by an individual after his death." ${ }^{4}$ Foucault's questions are intended to bring about recognition of just how fragile are the concepts at the heart of literary study. "The Author" and "the Work" are arbitrary figments, not securely identifiable entities. And so they are. But if the exclusionary practices of the archive are the basis for such assertions, Middle English 
scholars, at least, have more pressing worries. ${ }^{5}$ Would that we had the laundry bills of William Langland, the address book of Margery Kempe! The Chaucer Life-Records volume is a substantial exception to the absence and loss that are our era's most striking characteristics, yet it hardly leads anyone to fret over whether Troilus and Criseyde is a work, or Chaucer its author. ${ }^{6}$ Medievalists tend to see themselves as guardians only, protecting from any further destruction what has survived the assaults of fire, neglect, Cromwell, and so many other powerful forces.

Yet this sense allows for a much more fine-tuned assessment of the forces behind the creation and maintenance of the literary archive at large, whether or not those forces entail the death drive and the pleasure principle, than do the archives of more modern eras. For Derrida's diagnosis of the "trouble" of the archive remains partial in its very gesture toward comprehensiveness: it is, he says, "the trouble of secrets, of plots, of clandestineness, of half-private, half-public conjurations, always at the unstable limit between public and private, between the family, the society, and the State, between the family and an intimacy even more private than the family, between oneself and oneself." This whole list might well ring true for students of modern, especially modernist, literatures. Scholars of Joyce's life and works are always coming up against some powerful combination of these forces. Yet most medievalists would encounter only the final item in this catalogue, by far the most important: those secrets at the unstable limit between oneself and oneself. This is the case because for the most part the medieval literary archive is relatively transparent and well defined. A working definition of the Langland archive as generally accepted, the focus of this book, would be the collection of the fifty-plus extant manuscripts of Piers Plowman; the history of the poem's reception and criticism; and those more abstract beliefs that have attained the privileged status as near facts, external guarantees, as it were, of other interpretations, such as statements regarding the authorship, localization, and political valence of Piers Plowman. Once in a while, to be sure, the other forces Derrida identifies do come to the fore. An important early manuscript, formerly owned by the duke of Westminster, for instance, is now in anonymous private hands, and has been on deposit at the University of York (Borthwick Institute for Archives, Additional MS 196) - but only on the strictest of conditions. This situation pushes the unstable limit of public and private to the breaking point.

Yet the relative absence of such dramas from Langlandians' engagement with the medieval literary archive to date offers them no promise of exemption from the questions Derrida and others have raised, or modernists 
exemption from considering the challenges of the medieval archive. For as The Myth of Piers Plowman will argue, this seeming tranquillity highlights our own role as the archive's archons, those guardians of knowledge whose interpretations create rather than emanate from a study of the archive. Derrida himself recognizes, if at one remove, that it is in the modern confrontation with the distant past that the mal d'archive presents itself most acutely. His final case study is a novel, Jensen's Gradiva, contemporary with Freud, one indeed that fascinated him, but whose protagonist, Hanold, is an archivist trying to bring the ancient past to life via his occupation as classical archaeologist. Hanold, writes Derrida, dreams of "reliving the singular pressure or impression which Gradiva's step [pas], the step itself, the step of Gradiva herself, that very day, at that time, on that date, in what was inimitable about it, must have left in the ashes." In Derrida's account, the dream turns out to be bibliographical in nature:

He dreams this irreplaceable place, the very ash, where the singular imprint, like a signature, barely distinguishes itself from the impression. And this is the condition of singularity, the idiom, the secret, testimony. It is the condition for the uniqueness of the printer-printed, of the impression and the imprint, of the pressure and its trace in the unique instant where they are not yet distinguished the one from the other, forming in an instant a single body of Gradiva's step, of her gait, of her pace (Gangart), and of the ground which carries them. ${ }^{8}$

It does not take much of a stretch to see that Piers Plowman, too, fits this description, perhaps even more interestingly than Jensen's novel does. Derrida obsesses over the pas; Langland, over his poem's passus, the same term, here denoting the "steps" that the dreamer, or the reader, takes en route to the conclusion. Hanold's Gravida is Will's St. Truth or Conscience's Piers the Plowman, an elusive figure who leaves behind traces, impressions, footsteps. And as Emily Steiner has argued, "Piers Plowman reveals the conditions of God's contract with humanity as the unpacking or unfolding of an archive of redeeming texts": Meed's charter, Truth's pardon, Moses's maundemaunt, and so forth. ${ }^{9}$ The need for a contract between God and humanity, which is the need for Piers Plowman in its author's mind, arises from the division of unity into plurality. This is what instills in Hanold and Will, and in their readers, the desire for that moment, that unique instant, in which the separation has not yet occurred. The fall generates the work in the first place.

The dilemma is replicated in more secular form in literary studies, especially of the pre-print era. Dozens of medieval manuscripts of Piers 
Plowman survive, but they almost never provide the basis of literary studies of the poem. Critics instead opt for editions, reproducing them down to the letter, out of a desire, it would seem, to recreate that instant before the author's words were distinguished from their representation by later scribes. More transparently with Middle English literature than anything later, the process of literary interpretation is the archaeological enterprise Derrida and Foucault, the latter in The Archaeology of Knowledge, pronounce it to be. Indeed, given its extraordinarily complicated textual history, Piers Plowman has a fair claim to be the work that most intensively puts the status of the archive to the test. What is the relationship between the texts attested in the surviving manuscripts and the author's original? How many authors were there? How did original audiences respond to early forms of the poem, and how did the poet in turn revise the work? It would be difficult to imagine any interpretative approach to Piers Plowman that is not somehow implicated, often quite deeply, in certain answers to these questions. And given the poem's historical importance in its day, whether in the Rising of I38I, its influence on Chaucer, or engagement by the Lollards, certain interpretations of the Langland archive underpin a substantial amount of scholarship into late medieval English culture, religion, and politics.

When Derrida indulges in one of those lists intended to encompass everything - "the trouble of secrets, of plots, of clandestineness, of halfprivate, half-public conjurations, always at the unstable limit between public and private, between the family, the society, and the State, between the family and an intimacy even more private than the family, between oneself and oneself" - the "work" itself, say, Freud's Delusion and Dream in Jensen's Gradiva, is merely one of the constitutive items of that archive, rather than the contested product of its interpretation. The constitution of the Langland archive, then, is no less fraught and contested, and no less subject to the powers of the archons, than is, say, the Freud or Joyce archive. Major differences lie in the facts that where the moderns might anguish over whether Joyce's laundry bills would undermine Ulysses's status as a "work," medievalists almost never have access to any authorial document; and that the archons, who determine the definition and users of the archive, are for Langlandians identical to those doing the interpreting: there is no unstable limit to speak of between the public and private, between the individual researcher and the State or the estate.

The most powerful archons of the Langland archive have been its editors, whose interpretation of the textual evidence as attesting three (or four) versions of Piers Plowman, A, B, and C (and possibly Z), all 
by a single poet, has been accepted wholesale as the single issue on which every critic must have a judgment. In my previous book I argued that certain assumptions about the archive predetermined the results of such investigations, with devastating results. ${ }^{\mathrm{IO}}$ The particular debate in which I there engaged suggests that the main argument of the current book holds true even at the most fundamental level: our field is engaged not in a negotiation between the transparent archive of historical facts and the ingenuity of the modern interpreter, but rather in the continual production of that archive in the first place. But the process plays itself out over and over, as is seen quite precisely where the terms of the debate seem to present themselves as straightforward questions of how we are to interpret the factual data constituted by the Langland archive.

It might thus be more accurate to say that literary scholars "fabricate," rather than "constitute" or "construct," the archive. Any of these terms would acknowledge that archives do not come into being of themselves, from which point they merely await consultation and interpretation. But literary history has easily appealed only to those archival materials that in turn support its assumptions, a circularity that justifies the less innocent connotations of the term "fabricate," which will appear in various guises throughout this book. My point is not that criticism has somehow engaged in fraudulent behavior, but that in general it has not subjected the archive to the sort of intensive examination that it applies to just about everything else. In this sense, the only true fraud, if a fascinating and appealing one, discussed in this book, the early-nineteenth-century literary forger William Dupré, renders visible, simply if extremely, the modern archon's role in fabricating, creating, the archive.

But if this book does not see the archive as a retreat from theory into a supposed repository of transparent facts, neither does it urge some postmodern abandonment of the archive as a positivist fantasy. That would result in intellectual paralysis, or, at best, the easy and implicit endorsement of the fabrications that have produced current paradigms, within rather than against which it would operate. Instead, I will advocate the incorporation of a self-aware, historically responsible study of the processes of archive formation into any attempt to interpret the archive. Among the particular projects such an approach would entail are a rigorous analysis of all the agencies behind stages of the text, including the authorial, scribal, readerly, and editorial; a nuanced definition of the text, which accommodates not just the manuscripts upon which editions are based, but also the lively traffic in excerpts and the evidence of oral transmission; the bracketing of received narratives that have taken on the veneer of fact 
(e.g., Langland wrote the $\mathrm{C}$ version in the site where its "best" manuscripts are localized) so as to follow the evidence; and an appreciation of the ways in which the histories of literary production and the rise of institutional archives created the circumstances in which we work today.

The rest of this Introduction will lay the groundwork for this book's pursuit of such questions by treating three episodes in the history of Piers Plowman's production and reception, together, crucially, with the modern construction of the frame of reference that has granted, or obscured, the episode's meaning. The basic point is that these two seemingly separate realms are indivisible: it is not just the rather banal fact that the archives are subject to competing interpretations, but that they are to greater or lesser degrees determined by those interpretations in the first place. Literary scholars cannot help but fabricate the archive to some degree, whether in the term fabricate's neutral or negative connotations. To tip the balance more favorably toward the neutral, we need to recognize the degree to which what we have taken to be interpretations of the received archive have been involved as well, or instead, in its fabrication.

\section{The melancholy of Joseph Ritson}

The element of the Langland archive that has, together with the authorship controversy, proved most contentious over its critical history is the issue of versions: $\mathrm{A}, \mathrm{B}, \mathrm{C}, \mathrm{Z}$, ur- $\mathrm{B}$, and so forth. With this topic any division between the manuscripts themselves (the foundational archive) and the modern study of them dissolves: the versions are what Langland wrote; the versions are the results of the modern interpretation of the evidence. Both have reasonable claims to be true, which is why critics addressing the questions of how many versions and/or authors there were must also confront the history of those very questions: must confront the archive of Piers Plowman criticism, which is what renders the archive of Piers Plowman texts comprehensible.

The figure cited most frequently as the first to identify in print the existence of three authorial versions is Joseph Ritson (I752-1803), whose reputation as an "impudent libeller" and "abominably conceited and impudent writer" (the hardly disinterested judgment of the Shakespearean scholar Edmond Malone, among Ritson's prime targets) has put him on the outskirts of British literary history. ${ }^{\text {II }}$ But Ritson's centrality to Langland studies is cemented by what George Kane has called his "radical insight," in the Bibliographia Poetica (1802), into the nature of the poem's manuscript variation: "it appears highly probable that the author had 
revised his original work, and given, as it were, a new edition." ${ }^{\text {"2 }}$ This conclusion is the result of his grouping of the witnesses to Piers Plowman into, first, the "printed copys, and (in substance) the Harleian MSS. 3954, 875, and 604I; the Vernon MS. in the Bodleian, Hales, in Lincolns-inn, and others" - that is, B and A, whose versions of Prol.I-IO all agree; and second, those with our C.Prol.I-II, which appear in the "MSS. Vespasian B.xvi, Caligula A [xI], [Royal] I8 B xvi[I], Harleian, 2376, Mr. Douce's and others."

Given its subsequent reputation, it would be easy to imagine this announcement as a major claim, worthy of special attention. In fact the comment appears only in a footnote in one of the many entries in Ritson's large-scale bibliographical survey of pre-I60o British literature, on which he had been collaborating with the antiquarian Francis Douce. "Have the goodness to look over the inclosed, \& make as many additions, alterations, corrections, remarks, \&c. as you possiblely [sic] can," Ritson wrote to Douce in December 1798; and Douce's additions and corrections in red ink dot the pages of Ritson's notebook, BL Additional MS IO285. ${ }^{\text {I4 }}$ This collaboration had collapsed in acrimony in early I8OI, when "a little girl who was in the room" as the staunch vegetarian Ritson was lunching on bread and cheese in Douce's home "very innocently looked up in Ritson's face and said 'La! Mr. Ritson, what a quantity of mites you are eating!' Ritson absolutely trembled with passion - laid down his knife, - and abruptly quitted the room!"'I5 Their relationship was irrevocably severed. In the Advertisement of the Bibilographia Poetica Ritson acknowledges "the kind attention, and literary exertions, of a very learned and ingenious friend," whom it is left for Douce to identify in his copy: "Originally F.D. but he afterwards cancelled the name from a bit of spite." Any hopes for reconciliation were dashed when Ritson died a year later, in the grip of madness in his chambers at Gray's Inn, where he was attempting to burn all his papers. The mal d'archive had claimed another victim.

The footnote regarding the "two editions" was enough to guarantee Ritson's importance to the history of Piers Plowman criticism. But there is more to the story, for many modern critics have preferred to look to what they take to have been his earlier musings, in that notebook with Douce's red annotations (BL Additional MS I0285), on the textual state of the poem: "The difference as well between the printed copies on the one hand and most if not all the MSS. on the other, as between the MSS. themselves is very remarkable. Of the latter indeed there appears to be two sets, of which the one has scarcely 5 lines together in common with the other" $\left(\right.$ fol. $\left.247^{v}\right)$. E. Talbot Donaldson influentially interpreted this as providing 
"evidence for supposing that Ritson had at one time" - that is, before the depressing final chapter of his life - "distinguished three forms of the poem." ${ }^{\text {" } 8}$ In this rendering, Ritson first gathers the printed copies and those B manuscripts that agree with them, then divides them from the remainder of the manuscripts, and finally finds "two sets" of "the latter," which means that the "second sentence must be a reference to the differences between the A- and C-Versions." later abandoned this insight has never been explained, ${ }^{20}$ but the seeming fact that he did has been supported as well by an appeal to the materiality of the archive: Vincent DiMarco says that the notebook entry is "written on paper which elsewhere in the manuscript bears a watermark of 1795 ," that is, as many as seven years before his published comments. ${ }^{2 \mathrm{I}}$

But a new entry to the Langland and Ritson archives reveals this to be just sloppy syntax rather than critical insight: Ritson only ever identified two, not three, "editions" of the poem. ${ }^{22}$ This is his copy of the first of Robert Crowley's three 1550 editions (known as sigil $\mathrm{Cr}^{\mathrm{I}}$ ), now Lehigh University Library 82I.I L265p I550, available in facsimile on that library's website, which includes substantial annotations on the opening and closing flyleaves. Its final entry reads: "There is such a difference between Cal. A.xI \& 604I (both ancient MSS.) that there are scarcely 5 lines together the same in any part of the poem: of which, in fact, there appears to be 2 sets. The P.CC. agree with 604I." ${ }^{33}$ The phrases that received so much attention in the notebook appear in identical form here: "scarcely 5 lines tog"; "there appears to be 2 sets." The printed copies are unambiguously included with the sets, not separated from them as previously assumed: "The P.CC. agree with 604I." And while Ritson certainly did enough work on his own to confirm this reading of the situation, his conclusion and even its wording had already appeared in a catalogue he consulted, that of Cambridge Corpus Christi manuscripts by James Nasmith, who says that MS 293, a C text, "differs greatly from Roger's [sic] edition of 156I (the only one that I have seen) the orthography is much more antique, and the variation so numerous that I seldom found three lines together the same in both," followed by a printing of its Prol.I-I3. ${ }^{24}$

Neither is there any possibility of any substantive gap between Ritson's inscription and the Bibliographia Poetica. ${ }^{25}$ At all stages of his engagement with Piers Plowman Ritson distinguished two editions, as it were, and never three. Yet it is still worth looking more closely at the context of this annotated $\mathrm{Cr}^{\mathrm{r}}$, which illuminates chapters of the poem's critical history that are much more interesting than the one that has occupied attention to date. As the sale catalogue of Ritson's books says, this copy contains 
"MS. notes and Index, and specimens of the various MSS. of Pierce Plowman's Vision; likewise mentioning where they are deposited, and accounts of the different printed Editions." ${ }^{26}$ These features together offer a comprehensive and representative picture of Langland scholarship c.I80o: musings on the poem's authorship (Ritson denies ascription to either Robert Langland or John Malvern, the two main candidates; see Conclusion); a survey of its history in print (he deems $\mathrm{Cr}^{2}$ superior to $\mathrm{Cr}^{\mathrm{I}}$ ); a judgment regarding the correct reading of Prol.I (Crowley's "set" vs. MS "soft," discussed by just about all eighteenth-century critics); ${ }^{27}$ a bibliography of Piers Plowman criticism; and, most remarkably, two indexes, one a list of nearly 300 words, and the other, just beneath it, a briefer list of "memorable particulars," from Ale to Waltrot (see Figure I). Such lists pervade the annotated copies of the sixteenth-century editions (the three by Crowley, plus that by Owen Rogers in 1561, taken mainly from $\mathrm{Cr}^{3}$ ). The best example appears over four front flyleaves of the copy of $\mathrm{Cr}^{\mathrm{I}}$ that is now Cambridge University Library (CUL) Syn. 7.55.I2, which, like Ritson's list, is arranged alphabetically, listing fifteen items beginning with "A" alone, from Absolucyoun to Averice. Others, such as the $\mathrm{Cr}^{3}$ that is now Duke University D.9 L282V, are a bit shorter and proceed sequentially through the text rather than alphabetically.

Among all this material in Ritson's copy, the most extravagant and valuable are the inscriptions from the manuscripts on which basis he distinguished the two groups: "The MSS. marked B agree with the PCC," he explains, with the excerpts from all the $\mathrm{A}$ and $\mathrm{A} / \mathrm{C}$ splices thus marked; those marked "A," by implication, our C manuscripts, are set apart. ${ }^{28}$ The Bibliographia Poetica already shows that Ritson collated the opening passage of the Prologue, whose versions in these copies are included here something we now know was first done in print by Nasmith thirty-five years earlier. The new information is that Ritson also transcribed the final seven lines of those manuscripts he deemed complete (A MSS being described as "imperfect"): C 22.380-6 (beginning five lines earlier for Harley 2376), and, for Harley 3954, the six-line conclusion comprising two unique lines followed by received A II.3I2-I3 and the explicit (see Figure 2). ${ }^{29}$ Ritson attempted faithful transcriptions of the manuscripts, preserving original orthography and abbreviations. ${ }^{30}$ This is the activity that eventuated in the analysis presented in the Bibliographia Poetica.

Like all great textual scholars, Ritson also recognized and spoke eloquently of the literary and historical merit of the literature under discussion. In the same notebook page that includes his famous classification of the manuscripts, he observes that the poem's satirical passages 
Hetterly. Hitterly. Hyne.4,6. Hohe. 85, 6 .

tronnes. 15:

Hopen. $8 \%, 6$.

Forthe. $9^{2}, 6.94$. Wynen pyne. 20,6. Wyfhen.83.

Nye.92.92,6.106. tiytte. 5 : Garne. ss, c. Geme.g\% yemb. oo: gepely. 80. gere figeftis. 40,6 . Yeane. $18,6.27,3,5,6,1144$. ged. 92,6. Goten. 70 .

Memorabe particulaus.

Ale. $2.3,6.35,6.82,110$.

Bifleopor in pactibind. \$5, 6.

Pooking. 35, 35,6.65,6.66, 84, 6. 33, 6, 34.

Pries of sondorn. Al.

Ponglable of the cowtell. 42.

Doremow. K4, 6 .

Din +76rit, 1300. 68, 6 .

Foturne myfoes. 53,6.

gecre in havacft. 82 .

Longiv. 98.

Mafionct. 33,6 .

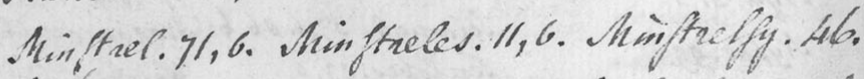

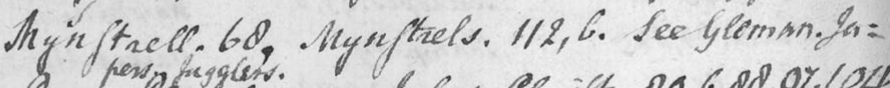

Sieice Slowghinan - fefres Cheift. 80,6.00,9\%, 104.

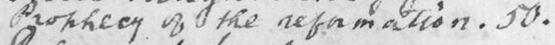

hormoinde.60, 6.

Shout oytch. 109,6 .

Waltrot, a take di. 99 .

Figure I Ritson's list of difficult words and "memorable particulars." Lehigh University Library 821.I L265p I550 [Endmatter 4] 


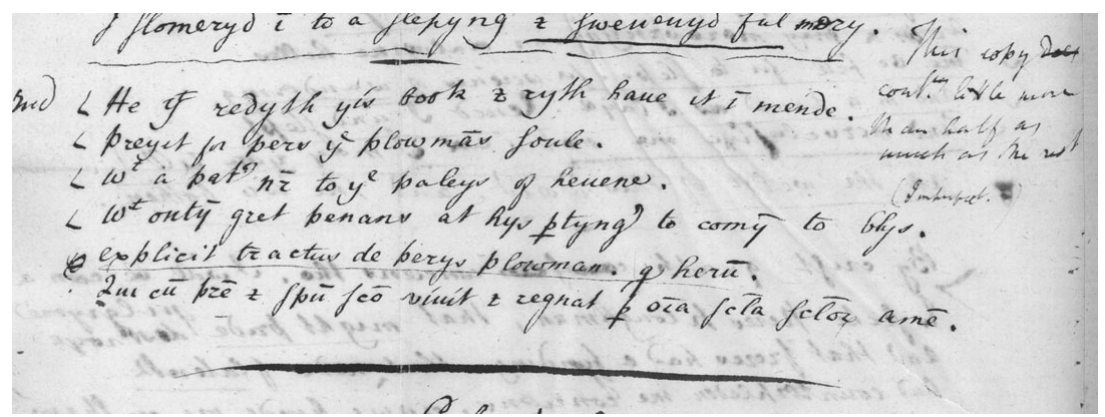

Figure 2 Ritson's transcription of Harley 3954's final lines. Lehigh University Library 82I.I L265p I550 [Endmatter 6]

concerning the clergy "are the most curious, not only on account of their poetical merit, but from the insight they afford into the manners \& customs of those times." But it turns out that he was of the C. S. Lewis school of Piers Plowman criticism: "It must be confessed, however, that excepting particular instances, the work is but a dull performance and scarcely merits the care of a modern impression." ${ }^{11}$ Perhaps if he had looked elsewhere than the opening and closing lines and noticed the extensive textual variation, that would have been enough to tip the balance. Seeing Ritson as a constituent rather than, or in addition to, interpreter of the Langland archive alters not just his story, but the field's.

\section{The gentleman's Piers Plowman: John Mitford and the authorship controversy}

The decades following Ritson's work on Piers Plowman would witness the dawn of the modern editorial era. Our next case, like Ritson's, shows how the printed sixteenth-century editions served as the foundations for the more widely recognized published scholarship on the poem - here, in an important piece never brought to light. While Ritson is less of an innovator than previously assumed, the gentleman scholar to whom we now turn merits a notable place in critical genealogy of Langland criticism. The story begins with an apposite observation from the April 1843 issue of The Gentleman's Magazine:

To the lovers of English poetry a more acceptable present could scarcely be made than a careful and critical edition of the Vision of Piers Ploughman ... The poem is among the earliest and the most curious in the language; it is, in fact, the earliest original poem in English, - it appeared nearly thirty years before the Canterbury Tales of Chaucer - it became excessively popular, as 
the numerous manuscripts attest; subsequently several editions of it appeared, - it was referred to by the early writers in our language, it was subsequently submitted to critical examination by Warton, Percy, and other critics, but it still was cased in its rough and almost impenetrable doublet of black letter,

until, that is, the editor whose volume is here under (anonymous) review, Thomas Wright, exercised his "courage and good taste" to change black letter "for a more appropriate and commodious form." ${ }^{2}$ Thomas Whitaker's I8I3 edition was of a quality to prompt its reviewer for The Gentleman's Magazine - again, not identified in the text, but now known to be Thomas Wright himself - to take on the "invidious" and "unpleasant" task of concluding that "the text which Dr. Whitaker has published, is not one with which we can be satisfied." ${ }^{33}$ No wonder the appearance of a proper new edition of this important poem was seen to constitute such a welcome present to the lover of English literature in 1843 .

The review of Wright's own edition just quoted was by the Rev. John Mitford (I78I-I859), and has never been known to historians of Langland's editing and reception. This is on account of its absence from Vincent DiMarco's invaluable Reference Guide, the catalogue-of-record for the Langland archive, probably on account of its absence in turn from the index volumes of The Gentleman's Magazine. ${ }^{34}$ Mitford, too, annotated his Crowley, a second edition, in which he signed his name and inscribed two dates, "I806" and "December I825," and which is the only sixteenthcentury copy of Piers Plowman known to have made its way to the southern hemisphere, where it is now in Melbourne's State Library of Victoria. The Oxford Dictionary of National Biography paints a picture of a man whose marriage was unhappy, and whose membership of the priesthood ill suited him. Instead, he "gratified his love of shrubs and books by planting a great variety of ornamental and foreign trees, and by forming an extensive library, mainly of English poetry": in sum, as Charles Lamb put it, Mitford was "a pleasant layman spoiled." 35 He produced the first serious edition of Thomas Gray, and between I830 and I839 edited numerous poets (Spenser, Milton, Dryden, Swift, et al.) for the Aldine edition. All of this made him well placed to take on the editorship of The Gentleman's Magazine in January i834, shortly before it published Wright's review of Whitaker.

Mitford, like Ritson a few years before him, used the flyleaves of his Crowley as a compendium of Piers Plowman scholarship, ranging from the sixteenth-century literary historian William Webbe (read in a reprint), who believed "Piers Ploughman" to be the poet (and "a very fitting" one, if harsh and obscure), to Ritson's rejection of Langland's or Malvern's 
authorship of the poem. There is also some room to make this copy a celebrity scrapbook, in the form of a pastedown of the catalogue entry for the Rogers owned by Alexander Pope (and, after him, Thomas Warton), which is found in other copies as well. ${ }^{36}$ The final front flyleaf adds a few more items from scholarly authorities, but also enlivens things with excerpts concerning Piers the Plowman from two of George Gascoigne's poems.

The appearance of Wright's edition in 1842 finally enabled Mitford to put these materials to good use in the public arena. Indeed his "review" is more an overview of the poem with supporting scholarly apparatus, most of which appears in the flyleaves of his Crowley, than an engagement with Wright's editorial procedures.

Its appearance in The Gentleman's Magazine guaranteed the review's influence, despite the lack of much original thought. Yet the Crowley edition contains other marks of Mitford's engagement with the poem that are not replicated in the review. For one, like so many others of this era, especially the protagonists of Chapters 5 and 6, he sporadically crossreferenced this volume with another text, in this case Whitaker's I813 edition of what we now call the $\mathrm{C}$ version. Most often he signals where the equivalent passage appears in Whitaker, but sometimes he records variant readings, such as at sig. Dd.iii" (B I9.238), "And some he taught to tyllye, diche and to hegge," where he writes "v. Whit. ed. p. 378. "leche, and to coke'." As in Ritson's copy, the back flyleaf contains a list of items that caught Mitford's attention, keyed to folio, from "Walsingham" (ii) to "Brybors, Pylors, and Pikehennes" (cxvi).

Mitford's engagement with Piers Plowman was taking shape just as recognition of the wild textual variation in its manuscripts was entering critical consciousness. Prior to Whitaker's I8I3 edition, the informed general reader could know from Tyrwhitt that some manuscripts seemed to differ from the Crowley text, which was so corrupted, he wrote, "that the Author, whoever he was, would find it difficult to recognize his own work," ${ }^{37}$ or, as we have seen, from Nasmith that scarcely three lines together are found between Corpus Christi MS 293 and Rogers's edition, or from Ritson that the variant forms of a few passages indicate "that the author had revised his original work, and given, as it were, a new edition." Whitaker's text confirmed that sense for most readers, and Richard Price, in his I824 revision of Warton's History of English Poetry, announced the existence of a "third version" of the poem. ${ }^{38}$ In his review, Mitford's own take on the textual variation found in the manuscripts of Piers Plowman (if it is indeed his - the bulk of his review is sourced from 
elsewhere, but I have not found the following in these sources) differs quite significantly:

From a comparison of the readings of the different manuscripts of this poem, it is our opinion that they are far too various and remote from each other to have proceeded by way of revision from the original author; but we consider that the poem was so popular, and so much in demand, as to lead persons of talent and leisure to make important variations in their transcripts. ${ }^{39}$

Although it is buried in a note, far from the focus of Mitford's energies, and never mentioned by subsequent scholars of the poem's reception, this is an important item in the history of Piers Plowman textual scholarship. Wright, too, had speculated that a single poet was not responsible for both his and Whitaker's texts (Wright seems not to have known of Price's "third version"): "it is my impression that the first [i.e., text printed by Crowley] was the one published by the author, and that the variations were made by some other person, who was perhaps induced by his own political sentiments to modify passages, and was gradually led on to publish a revision of the whole." ${ }^{40}$ Although this comment probably influenced Mitford, he goes much further, seeming to posit, quite accurately, the existence of more than two textual states, and certainly suggesting, in the phrase "persons of talent and leisure," that more than the two authors identified by Wright were responsible for this massive variation from Crowley's text.

Such a belief would become quite prominent in the first half of the next century, when debate raged over whether Piers Plowman was "the work of one or of five." ${ }^{\text {II }}$ While no advocate of multiple authorship ever cited the Gentleman's Magazine review of Wright's edition, it does seem to have had an impact on an important scholar who would figure in that controversy: George P. Marsh, the American philologist, environmentalist, and diplomat who by this point, I862, had been appointed United States Minister to Italy by President Abraham Lincoln, and who wrote of Piers Plowman:

The number of early manuscripts of this work which still survive proves its general diffusion; and the wide variations which exist between the copies show that they had excited interest enough to be thought worthy of careful revision by the original author, or, as is more probable, of important modification by the numerous editors and transcribers under whose recension they subsequently passed. ${ }^{42}$

John M. Manly, who had instigated the authorship controversy in 1906, cited this in support of his cause, noting in his 1916 essay "The Authorship of Piers the Plowman" "that Marsh's views are much more precise and 
definite than those of Thomas Wright, and contain in effect, though not in detail, the conclusions for which I have contended. I am glad to have the support of an independent utterance from a scholar so distinguished for soundness of taste and sanity of judgment as was Mr. Marsh."

Subsequent critics have seen Marsh's comments as signs of his indebtedness to Wright, ${ }^{44}$ but Manly is quite correct to point out that some differences separate the two, ones that suggest that Marsh had the Gentleman's Magazine review of Wright at hand as well. Wright's remark that "as might be expected in a popular work like this, the manuscripts in general are full of variations" certainly lies behind the similar remarks of both later scholars; ${ }^{45}$ but where he proceeds to isolate "two classes of manuscripts which give two texts that are widely different from each other," ${ }^{46}$ Mitford and Marsh instead identify "important variations in their transcripts" by "persons of talent and leisure," and "important modification by the numerous editors and transcribers," respectively. This attribution of the variant texts to multiple, conscious agencies rather than scribal corruption (as in Tyrwhitt's analysis) is a new idea, one that Manly attributed to Marsh alone, but which at least belongs first to Mitford as chronologically prior, and probably as source of his successor's idea. It is unlikely that someone as well informed and intelligent as Marsh would not have consulted the review of Wright's edition in The Gentleman's Magazine, and there are no other known sources for the idea until Manly resurrected it the following century.

\section{The Piers Plowman Electronic Archive: how many manuscripts?}

If Mitford saw Wright as a worthy archon after earlier missteps, many of today's critics would prefer none at all. Thus the editors of the Piers Plowman Electronic Archive (hereafter PPEA), launched in 1990, played the heroes of Charlotte Brewer's book on their kind because they intended "to make accessible to their users the essential data which underlies a critical edition but is usually obscured by it: facsimiles and transcriptions of all the individual manuscripts, and the reconstructed archetypes of A, B, and C." ${ }^{47}$ This is among the generation of projects that has breathed new life into the concept of "the archive." No longer does the Modern Language Association give a prize for best bibliography: now it is for a bibliography, archive, or digital project, a shift in which the PPEA played a prominent role. ${ }^{48}$

In light of its reputation for presenting "each manuscript unmediated by predetermined assumptions," in a more recent critic's judgment, ${ }^{49}$ the 
PPEA's original aims are easy to forget: "We can promise readers of Piers Plowman a text substantially better, more true to what the poet wrote than any of the editions now available." ${ }^{\circ \circ}$ Perhaps sensing a change in the wind, the project's editors now do not even mention the poet in their recent revision to the website. Authority is now vested in its users, who are provided "with unprecedented access to each manuscript we edit," and allowed "to decide for themselves how to interpret the complexity of the raw data, while also giving users the option of approaching the poem with a more traditional editorial apparatus." ${ }^{.51}$ What remains missing is any clear definition of "the archive," the "raw data" to which the project intends to provide wide access. The qualifier in the first sentence above - "each manuscript we edit" - hints at a process of selection, of the omission, the burning, on which Derrida muses. But all the other rhetoric here suggests quite the opposite, that "we" edit all the manuscripts. Thus the project's list of manuscripts includes three items left out of A. V. C. Schmidt's equivalent list, ones that he says "have no textual value": "the sixteenthand seventeenth-century transcriptions and excerpts in Bodleian mss James 2, Wood donat. 7, the BL ms Sloane 2578." 52 Since the PPEA is not bound by such notions as "textual value," that is, the need for any manuscript to have the potential to provide independent witness to the authorial text, it pursues the more democratic aim of offering all users access to the "raw data" of even such productions, which are worthwhile in their own right as witnesses not to the author's text but instead to "the richness and complexity of the textual tradition of William Langland's Piers Plowman," which can be gained "by providing a transcription of the text of each manuscript."

The sticking point is the phrase "each manuscript." For Schmidt and other author-based editors, the entity would comprise those witnesses of potential textual authority (hence the inclusion of one non-manuscript, Crowley's text, also included in the PPEA's list). But once those limits are gone, and items omitted by Schmidt on those grounds are now included, what can "each" mean? The PPEA editors do not mention the fourth item Schmidt explicitly excludes: Cambridge, Gonville and Caius MS 20I/I07, a complete MS of the B version, copied from Rogers's 156I edition - which is also missing. ${ }^{53}$ And this just scratches the surface. There are also:

- Cambridge, Trinity College MS R.2.36, a complete MS of the C version; ${ }^{54}$

- BL Additional MS 29490, another complete MS of the C version;

- the list of Piers Plowman's Latin lines in a fifteenth-century hand immediately after the conclusion of an A-text MS; 
- the same (a different selection, hand $c$.I2O years later) on the blank page facing the first page of text in a $\mathrm{Cr}^{2}$;

- the single line on a flyleaf of Bodley 85I (not taken from the "Z-version" text elsewhere in the volume);

- the line in a margin of a Canterbury Tales manuscript;

- Prol.I-4 at the conclusion of Huntington MS Hm I43; ${ }^{55}$

- four lines at the top of a page after the end of the main text of London, Society of Antiquaries MS $687 ;^{56}$

- any of the lines added to the extant MSS by the "other hands" mentioned throughout the Athlone apparatus;

- the completion of defective BL Additional MS 10574 in the hand of Dr. Adam Clarke (I760-1832), probably copied from Huntington Hm I28 (this will probably be included in the PPEA edition of that MS: but other than its location it is of equal status to the following, which will not be); ${ }^{57}$

- the completion of any number of defective printed editions (e.g., Southern Methodist University 00712; Boston Public Library G.406.32; UCLA PR2OIo Ar 1550) via manuscript facsimiles;

- Joseph Ritson's transcriptions as discussed above;

- the transcriptions, by other eighteenth-century figures, like Thomas Tyrwhitt, John Urry, Frederick Page, and William Burrell, of lines and passages from other MSS in their printed copies.

On the one hand, there is no evidence that the PPEA editors even knew, or know, of any of this material, all of which is discussed somewhere either in footnotes here or elsewhere in this book. On the other, any project that identifies itself as "the Piers Plowman archive," one unconstrained by the strictures of former archons, might seem obliged to fulfill its promise first and foremost via the definition of that archive, by seeking out all manuscript witnesses to that tradition's richness. As it stands, the criteria behind these exclusions, if such they are, are difficult to identify, and inconsistently applied. If date is important, the cut-off lies somewhere in a 220-year period (between $c .1647$ and I867), for no stated reason; textual authority does not matter in the case of James 2, Wood donat. 7, and Sloane 2578, and cannot if the rhetoric of inclusiveness is to be taken at face value, but seems to be silently all-powerful in excluding the items in this list; proximity with other items already counted as "manuscripts" somehow matters, given that one Prol.I-4, jotted in a late-fifteenth-century account book (Kew, National Archives Eıor/516/9), is in while another, earlier Prol.I-4 is out; and on and on. And when we consider that the same applies to all medieval literary texts, especially Chaucer's (and a previously 
unknown MS line from the Romaunt of the Rose in a print copy of Langland will come to light here, joining ones from Gower and "John of Bridlington" I discovered earlier in a Langland MS), ${ }^{58}$ the assumption that statements like the following relay an "archive of factual evidence" cannot easily stand: "The fact that enough manuscripts survive for Piers Plowman - 59, including fragments and extracts - to make it the third-ranking Middle English poem after Prick of Conscience (over II5) and the Canterbury Tales (82, including fragments and extracts), can no longer be construed solely as a function of aesthetic tastes detached from other cultural factors." 59

Such appeals to the number of "surviving manuscripts" pervade medieval literary scholarship, but I have rarely seen anyone explain what meanings one hopes to extract from them. These statistics seem to be used as indications of the relative popularity of given works. As such they rely on a faith that the ratio of surviving-to-lost manuscripts is consistent across different works and eras. ${ }^{60}$ That problem aside, it remains unclear why only the extant manuscripts are included. If there is no question that, say, MSS R and F of the B version descend from a now-lost copy, why not add that copy to the tally? Why not the rest of the now-lost but securely identifiable manuscripts? And to get to the fundamental issue, what is the value accorded a "manuscript" as opposed to a printed copy? The PPEA editors do include the Crowley editions (if not their extant copies) on account of their textual authority, a reminder that such lists are not usually of "manuscripts" at all, but of witnesses. But if these are no longer necessarily witnesses to authoritative texts (hence the inclusion of James 2 etc.), it is unclear to what entity they bear witness. If that entity is "the richness and complexity of the textual tradition of William Langland's Piers Plowman," then the question of why the excerpts written out by MS James 2 merit consideration, where those printed by James Nasmith in his catalogue of Corpus Christi MSS do not, calls for explication.

Now, if the editors had been as true to their stated purpose as they might have, they would never have started on the project or received any funding for it. I am not at all saying they should have, and I am full of admiration for the project and its aims. My edition of National Library of Wales MS ${ }_{733} \mathrm{~B}$ will be part of the project soon. What I am urging is, first, a more serious approach to the concept of "the Piers Plowman archive" than that project (which had the opportunity to take up that challenge) or anyone else has pursued, and second, a broader recognition of what these heroic practitioners already know, that the archons are creating the archive to which they devote their energies, and that the collection of data they present is not, and could never be, raw and unmediated. 


\section{The fabrication of Langland}

The cases of Ritson, Mitford, and the PPEA are especially instructive in that each of these interpreters of the archive is both its creator and, no less, its constituent. Each case shows that the recreation of the instant before the foot left behind its trace entails the interrogation as well of the means of our recreation. Doing so no doubt ensures the futility of any hope not just for direct access, but even for any reliance on the transparency or integrity of the archives apart from our desires. It is my contention that this aspect of the literary archive is clearest where there are by far fewer other archons at whose feet to lay any charges of distortion, that is to say, in the medieval literary archive, within which the Piers Plowman event offers the best hope for a clear recognition of the situation.

In setting out the case in detail, The Myth of Piers Plowman will treat all the major components of the production and reception of a literary work: questions of authorship, oeuvre, localization, oral transmission, editorial history, forgery, and translation play equal roles in the story I will tell. The first half focuses on the pre-print era, before modern modes of editing become prominent. Chapter I instantly queries the absolute dominance of Piers Plowman as governing principle of this sizable proportion of the Middle English archive, asking why critics have been so content to identify that poem's author so completely with the poem itself. To put it another way, a slight shift in our identification of the archival evidence - paleographical, linguistic, historical, and prosodic - brings the fanciful romance William of Palerne, with its werewolf and lovers in bear-suits, into the picture as a potential piece of Langlandian juvenilia.

The idea was first mooted by George Kane, and has begun to be taken seriously in some quarters, but the Langland archive, so I argue, will have to shift much more fully from the demonstrative to the subjunctive as its dominant mood if it is to maintain its integrity as the foundation for studies of the works and productions closely associated with its namesake. This chapter presents the flip side, as it were, to C. David Benson's interrogation of "The Langland Myth," the treatment of Piers Plowman "as a record of an individual poet's life and views." ${ }^{11}$ Benson's discussion of the dangers of such an approach is apt, but the replacement of the single author "William Langland" with a single title, "Piers Plowman," incurs its own set of risks. What Chapter I inaugurates is similar in spirit, if not in the particulars of its approach, to Benson's questioning of the creation of our field of study: it is no surprise that the concept of "myth," which he 
defines as "a narrative that explains what is unknown and perhaps unknowable," features so prominently in both studies. ${ }^{62}$ The main difference is that my focus is on how "the unknown" so often turns out merely to be "the unlooked for" or "unconsidered," such as the idea that Langland could have composed William of Palerne.

Where Langland wrote has long loomed about as large as what he wrote: and as with the concept of authorship, it is both the foundation for and product of the interpretation of the Langland archive. Few literary works invite localization more persistently than does Piers Plowman, which in so many ways suggests that its meaning is to be found not only in its words and manuscripts, but also in the site of its composition and early circulation. Among Chapter 2's central claims is that the surviving manuscripts of Piers Plowman embody no "evidence," per se, whether in their dialects or the sites of production, for the location of the poet when he was writing. But their words still might, a possibility I follow up in proposing a previously unnoticed reference to the London riots of 1384 in the $\mathrm{C}$ version. Chapter 3 turns to the murky ground between the authorial and the scribal in the production of Piers Plowman: a ground most clearly signaled wherever Latin tags that could easily stand apart from the poem appear. It was the poem's Latinity, precisely because of its status as the lingua franca of the literate, that enabled a substantial proportion of its audience most directly to come to terms with its message. The poem was to them not so much a brilliant poet's vision as a site open to audience contributions not found elsewhere in the canon of major medieval English poetry.

The second half of the book concentrates on the era in which the modern "Piers Plowman" came into being, beginning with the sixteenth century. Chapter 4, "'Quod piers plowman': non-reformist prophecy, c.1520-1555" begins with a six-line sixteenth-century excerpt of "the hunger prophecy" from B passus 6 , in the staunchly Catholic/recusant Winchester Anthology, which is among the six independent productions, together constituting the great bulk of sixteenth-century witnesses to the B version, that juxtapose or draw particular attention to two of the poem's "prophecies," and that have a character similar to that of the detachable Latin of the manuscripts: both part and not part of "Piers Plowman," especially in failing to fit within the standard narrative of "Piers Protestant." The Langland archive has mistaken as the mainstream a mode that in fact constituted a rearguard attack on the predominant approach.

The era between 1550 and Whitaker's first modern edition of $18 \mathrm{I} 3$ is commonly assumed to be "a comparatively fallow period for Piers 
Plowman textual scholarship." ${ }^{63}$ Not at all, Chapter 5 shows. Using the fortunes of San Marino, Huntington Library MS Hm II4 as its focus, it uncovers extensive evidence of collation, and of the movement of items in and out of collections and libraries. These items' resistance to any accommodation by the historians and fabricators of the Langland archive only underscores the imperative not to write them out of our story. Chapter 6 brings the concept of "fabrication" to the forefront of the book, here literalized in the career of the first translator of Piers Plowman into modern English, who came of age during the controversies surrounding the Shakespeare fabrications of the 1790 , in the realms of both portraiture and document.

The Conclusion brings together the main strands of the book by tracking the creation of the previously unnoticed belief that Chaucer wrote Piers Plowman. Both in its formation and in its effects, this belief underscores the fact that the archive is our fabrication. Michel Foucault asserts that we must recognize that such concepts as the "oeuvre," the "book," and even "literature" "may not, in the last resort, be what they seem at first sight. In short, that they require a theory, and that this theory cannot be constructed unless the field of the facts of discourse on the basis of which those facts are built up appears in its non-synthetic purity." ${ }^{64}$ While by no means rejecting Foucault's insistence on the imperative to theorize, The Myth of Piers Plowman urges an empirical application of such theorizing, a testing of the case, which will certainly confirm that the categories we have inherited are not quite what they seem at first sight, but are still within view, even if only via the footsteps and traces they have left behind for us to follow. 


\section{William and the werewolf: the problem of William of Palerne}

The establishment of the corpus is the foundation of any author's literary archive, one so important that it is usually taken as a given before the work of scholarship begins. Any challenges to a set corpus, such as the attributions of The Lover's Complaint to Shakespeare or the French poems of "Ch" to Chaucer, usually take place on the borders of scholarly interest. ${ }^{\mathrm{I}}$ Even the discovery of new works, such as those recently discovered vitae by the fifteenth-century monk Osbern Bokenham, usually does little to change the overall picture of the author's work. ${ }^{2}$ The proportion of women's lives in Bokenham's oeuvre is now different, but in all fundamental ways the works discovered alter its size, not its character. There are no real equivalents to any of this with regard to the Langland oeuvre. Debates used to rage over whether Piers Plowman was the work of one or of five, and have more recently centered on the status of "the $\mathrm{Z}$ version" and on the order of the received versions, but either way, the only thing ascribed to Langland is that work, however many letters it might comprise. $^{3}$ Yet, as this chapter will argue, the peculiarities of the Middle English alliterative tradition render the issue of Langlandian attribution much different.

The case in hand took shape before October 15, 136I, the date on which Humphrey de Bohun, the sixth earl of Hereford and fifth earl of Essex, died. Humphrey had at some point commissioned one "William" to translate the fanciful French romance Guillaume de Palerne, "For hem pat knowe no Frensche, ne never underston" (552I, 5533). ${ }^{4}$ The result is no doubt the oddest duck within the corpus of formal Middle English alliterative poetry, and perhaps its earliest surviving instance (depending on when Winner and Waster was written). ${ }^{5}$ While Piers Plowman, the Parliament of the Three Ages, Sir Gawain and the Green Knight, and the rest of this group focus their energies on expounding the nature of penance, William of Palerne strikes a much more jejune tone, telling of a werewolf, a boy who makes love to his pillow, and, most prominently, 
lovers dressed in bear- and deer-suits. ${ }^{6}$ Did its author go by the last name "Langland," or perhaps, as suggested by the ascription in Dublin, Trinity College MS 212, "Rokele"?

If such a question is reasonable, the consequences for the Langland archive are substantial, and enable literary scholars to see what happens when questions of attribution move from the periphery to the center of discussion. Such questions affect the very character of the archive, rather than just rearranging its borders. Attribution of William of Palerne to Langland would both double the number of titles in that archive and produce a dramatically different picture of the poet of the dream vision, and perhaps of that work itself. It would put the inscription of authorial identity, so central to a few passages of Piers Plowman, and thus to much modern criticism, in a new light. The emphasis on atonement in the later work might connect to the poet's earlier career. So too would French occupy a much larger place in Langland's history. While it is commonplace to state that Piers Plowman is among a group of Middle English poems that show "considerable influence from French love narrative and Piers ..., in particular, from the dream device that is prominent in the French tradition," and perhaps from the tradition of the Grail romances, few have connected him with such romances as Guillaume de Palerne. ${ }^{8}$ If Langland began his career by translating a long French (non-dream vision) poem it would bring him into much closer communion with his peers Chaucer, Gower, and the Gawain-poet.

The idea probably seems new to most readers. In 1988 David Lawton observed that, even in the wake of Angus McIntosh's proposal that "the innovatory work of a single individual" might account for the peculiarities of the alliterative corpus, "lovers of Piers Plowman have been stupendously silent about any slight chance that [the William of Palerne poet's] surname was Langland." Since then there have been a few stirrings: George Kane, if only in an endnote to a belatedly published essay, nominates William of Palerne as the best candidate for the "earlier apprenticeship" that, "because the A version of Piers Plowman is altogether accomplished writing," he presumes for Langland, ${ }^{\mathrm{IO}}$ Andrew Galloway has called such speculation as that in which I engaged in an earlier version of this chapter "intriguing," and A. V. C. Schmidt says the possibility "deserves to be carefully examined, as the lexical and metrical evidence of affinity from all four versions is very suggestive." ${ }^{\text {I2 }}$ Even so, no one has taken up the cause in earnest, most likely because the notion that Piers Plowman is in effect a synonym for "William Langland" is so firmly entrenched. Even the earliest external testimony about the career of the poem's putative maker, John But's 
explicit statement that Will wrought Piers Plowman and works other than that poem as well, has been taken to refer to Piers Plowman alone. ${ }^{\mathrm{I}}$ This chapter pursues the case, even though it reaches no firm conclusion. On the one hand, there are reasonable, if not very compelling, objections to the idea; on the other, though, the historical, linguistic, and cultural indicators are strong enough to force a shift from the demonstrative to the subjunctive as scholarship's dominant mood. That is why the case is worth pursuing: for any comprehensive history of Langland's career, or of Middle English alliterative poetry, must come to terms with the centrality of the phrase "if William of Palerne is by Langland ..." to its quest.

\section{The question of evidence}

Who wrote Piers Plowman? There are other major literary works that have resisted attribution as forcefully - Beowulf, the poems of Cotton Nero A.x yet none of them has generated anything like the "authorship controversy" discussed in the Introduction, or has seemed to thematize the very question, to the extent that Langland's poem has. The very name "Langland" is as much a convenient alternative to "anonymous" as a likely surname of our poet; and whether or not the author of Piers Plowman used it in real life, as is suggested by a fifteenth-century note appended to one manuscript, he seems to have inscribed it - and thus the very topic of the poet's social identity - in what appears to be a reverse acrostic, "Ich have ylyved in londe,' quod Y, 'my name is longe wille'" (B 15.152). ${ }^{\text {I4 }}$ Whatever the poet was called, the question of his name is a key to the status of the dreamer's identity, and perhaps even to the meaning of his visions. In light of the prominence criticism accords this authorial self-inscription, it might be tempting to question the attribution of William of Palerne to Langland on the grounds that it treats authorship as something external rather than a driving theme. Yet so does the A version of Piers Plowman.

In the absence of any compelling reason to dismiss the possibility out of hand, at least on the grounds of an interest in authorship, a substantial list of historical factors and coincidences renders the possibility worthy of serious attention. In 195I Kane wrote of Piers Plowman, "The earliest version, the A-text, is certainly not the work of a beginner; in fact it shows great poetic assurance in its author," with only William of Palerne, Alexander A, and Alexander and Dindimus resembling it "both in the nature of its use of the alliterative long line and in the ability with which this appears to have been used." I5 The assumption that Langland wrote something in the aa/ax mode prior to Piers Plowman, whether A or Z, only 
stands to reason. By the same token, the existence of William of Palerne, a poem very accomplished in its own right, for which at most only one formal metrical model survives, would be less astounding if its author was imaginative and innovative enough to go on to produce Piers Plowman. Both poets seem to have been called William, though I will not go so far as to find a reverse acrostic of the author's name in William of Palerne's lines "And with lordesse of pat lond pat him long hade missed. / And William wi3tli" (4539-40) in the manner that Langland's critics do with the B I5 acrostic quoted above. ${ }^{16}$ The terminus a quo of Piers Plowman, the great storm of January I5, I362 (A 5.I3-I4), is three months after the romance's terminus ante quem. ${ }^{\mathrm{I7}}$

None of that would matter if the two poems did not share so many linguistic similarities. The William-poet's dialect, according to its most recent editor, was "possibly one belonging to southern Worcestershire or Warwickshire, not very far from the area where Langland acquired his linguistic habits," which, given the fact that William of Palerne still "presents the most difficult dialectal problem of all the alliterative poems owing to the peculiar mixture of forms," in the early and still valid judgment of J. P. Oakden, is as close a relationship between two works with entirely separate histories of transmission as anyone could expect to find, even if common authorship were not in doubt. ${ }^{18}$ The textual features of the Piers Plowman manuscripts BL Harley 2376 and Cambridge, Trinity College B.15.17, for instance, are much more distinct from one another than are those of the putative authorial Piers Plowman and William of Palerne, yet no one attributes those texts to separate authors. ${ }^{19}$ And Langland exhibits the "easy familiarity with French" and "awareness of the fluid and shifting relationship between French and native English" that the poet of William of Palerne must have had as well. ${ }^{20}$

Attributionists satisfied that the proposal is worth pursuing would at this stage usually apply tests, but none is of any use in this case, at least. Lexical frequency might have been worth comparing were it not for the wildly divergent subject matters of the two poems on the one hand and the conventional nature of alliterative verse on the other. ${ }^{2 \mathrm{I}}$ William of Palerne's use of the term "pas" to denote a section of the poem (I6I) looks promising in light of the prominence of its Latin equivalent, passus, in the later poem, but this usage "became well established in alliterative poetry," appearing as well in The Wars of Alexander and The Siege of Jerusalem. ${ }^{22}$ Some attributionists look for "certain unconscious features of expression that characterize the style of the individual writer," such as the distribution of unstressed syllables or the use of terms like and or but at the beginnings of lines, ${ }^{23}$ but 
as Kane remarks, "to identify such data effectively one would have to know the answer to the problem." ${ }^{24}$ In any case, even if Schmidt's judgment that the linguistic evidence is "very suggestive" of common authorship is off base, any fundamental differences between William of Palerne and Piers Plowman would be easily accounted for by Kane's "apprenticeship" proposal. $^{25}$

"What is the evidence to suggest it?" ${ }^{26}$ Thorlac Turville-Petre's challenge to those who wonder whether Langland wrote William of Palerne is apt. On the one hand, the answer is "none," insofar as all these potential indicators are explicable by other means. On the other, though, their quantity and quality are such as to make the proposal difficult to dismiss out of hand. To maintain silence about the possibility is to come up against the inverse question: on what grounds should the possibility be ignored? There are all sorts of reasons to reject the attribution of William of Palerne to every poet in the history of English literature, save Langland alone: on what grounds should we reject that attribution, too?

Christine Chism has called for "a critical change in direction" in which we "beg temporarily the etiological questions traditionally asked of fourteenth-century alliterative poetry as a group: 'how did it come about? who wrote it? where and in what dialect? and move to more blatantly interpretive questions. Do these poems share common interests? Do the worlds they create resonate with each other?" ${ }^{27}$ The answer to these interpretive questions as applied to William of Palerne and Piers Plowman, once we beg the question of authorship, is "yes" - an answer that itself undermines the willingness of criticism to assume that authorship is a question that must be begged if we are to engage in interpretation. In the absence of a secure Langland archive that either includes or excludes William of Palerne, it seems appropriate, perhaps imperative, to see what happens if we bring the two poems into such conversation as Chism urges. This will result not in an archive any more secure than it is at this stage of our investigation, but, at the least, in a recognition of the inevitability of such insecurity. The arbitrary nature of any sense that Langland equals Piers Plowman unless his authorship of other works is proved beyond reasonable doubt will become much clearer. So will the benefits such insecurity can reap in our continual negotiation of the medieval literary archive.

The next section will delineate these poems' common interests not to argue positively for common authorship, which would be rash, but to show that the common belief that these poems "share none of the same concerns and possess none of the same qualities" is not quite right, ${ }^{28}$ 
indeed, to suggest that these concerns are in fact central to both poems. The later poem itself might well comment on the authorship of William of Palerne in a way that accounts precisely for the differences that have led to these poems' occupation of such different places in the critical discussion.

\section{Sheepskins, bearskins, and the topos of regret}

If the translation of Guillaume de Palerne served as Langland's apprenticeship, then the relationship between animal skins and identity established in the opening lines of the dream vision is no longer the major problem it has long been:

In a somur sesoun whan softe was pe sonne

Y shope me into a shroude as y a shep were;

In abite as an heremite, unholy of werkes,

Wente wyde in this world wondres to here. (A Prol.I-4)

"The expression needs further study," says Turville-Petre about line 2, immediately after having dismissed William of Palerne from consideration:

What does it mean for Will to say he dressed as a sheep? One might suppose that such an arresting characterization would reverberate through the poem, with flocks of biblical and agricultural sheep lost, or grazing in pastures, or for the slaughter. But in fact there is not one other reference to sheep in the Athlone B text! It is, as Holmes should have said, the dog that did not bark in the night. ${ }^{29}$

The poet of William of Palerne would have had plenty to say about the problem. As Skeat observed, the "curious fancies" of the werewolf and animal skins in William of Palerne "form the true groundwork of the story, and no doubt, at the time, attracted most attention," even if they test modern readers' patience. ${ }^{30}$

The initial appearance of its interest in the theme of deceitful, beast-like appearances comes in the figure of the benevolent werewolf, Alphouns, son of the king of Spain, transformed by his wicked stepmother's evil spell. ${ }^{3 \mathrm{I}}$ The theme gets still more outrageous when the heroine, Melior, is about to be forced into a royal marriage, prompting her attendant, Alisandrine, to help her to escape with her lover, William, by putting her into the suit of a white bear, "Pat no man upon mold mi3t oper parceyve / But sche a bere were to baite at a stake" (1722-3). In the French, by contrast, she looks not as if she were a bear, but "Ensi comme ele estoit vestue / De ses garnemens les millors" ("Just as if she were dressed / In her best garments" [3076-7]). ${ }^{32}$ 
"Am I noust a bold best, a bere wel to seme?" Melior goes on to boast to Alisandrine (I728); a minute later William joins the fun by dressing in his own bear-suit, eliciting mock-terror from his companion: "So breme a bere ze beseme a burn on to loke, / Pat icham agrise, bi God pat me made, / To se so hidous a si3t of youre semli face!" (1742-4). Again, the French is quite staid by comparison: Melior just asks how she looks ("Bele, que te samble de moi?" [308I]), and tells Guillaume only that her heart trembles because he seems so fierce ("li cuers me tramble, / Quant vos esgart, si samblés fier" [3098-9]).

This common interest in animal disguises suggests the possibility that Will's disguise "as a sheep" alludes to the earlier work, whose relative frivolity prompts his atonement in a form of "disguise" that has now become a sign of its wearer's penance. Admittedly, this idea runs up against what nearly all critics have taken to be the "obvious sense" of Will's sheepskin: that he is a "wolf in sheep's clothing." ${ }^{33}$ But that interpretation, as Dee Dyas has commented, is "dangerously misleading" in that the passage contains neither any wolf nor the corrupted clergymen who have cure of souls, for whom medieval authors reserved the appellation, says David Lyle Jeffrey, "almost exclusively." 34 An alternative that sidesteps those problems would have it that Will's hermit, sheep-like dress represents not his unsanctified works themselves - "unholy of werkes" means "'without holy works to his credit' (but not, because of that, necessarily a man of sinful works)" 35 - but rather his repentance of them. The b-verse of line 3, "unholy of werkes," would here be subordinate to the $Y$ of line 2's "Y shope me," which, crucially, is necessarily understood as well as the subject of line 4: "I, unsanctified of works, dressed myself in garments as if I were a sheep: in this hermit's habit, I went wide in this world." 36

The historical foundation for this reading, too, is much more solid than for the received one. The sheepskin or goatskin of monks "signifies that having destroyed all wantonness of carnal passions they ought to continue in the utmost sobriety of virtue," explains John Cassian, fifth-century monastic theorist, "and that nothing of the wantonness or heat of youth, or of their old lightmindedness, should remain in their bodies." ${ }^{" 37}$ As David Lawton has commented, "Penance, both on the individual and the social level, is Langland's primary concern in Piers Plowman"; a reader thus might well expect this concern to be established in the opening lines of the poem..$^{38}$ It certainly recurs when the dreamer describes himself as "Wollewaerd" (B I8.I), meaning "with the body towards wool" or "dressed in wool only," as was "often enjoined in times of superstition, by way of penance," in R. A. Nares's quaint explanation. ${ }^{39}$ 
One question the opening lines immediately prompt is: what are the "works" that are unsanctified, "unholy"? The standard approach to the lines assumes they are sinful ones in general, no need to specify. But the rest of Piers Plowman suggests that they are something quite particular: Will's writings, a usage we find in Will's pugnacious observation that the "werkes" of Aristotle and Solomon did not save them from eternal pain (B IO.392-4), and John But's reference to Will's writings besides Piers Plowman as "oper werkes" (A I2.IOI). ${ }^{40}$ To date there has been little alternative but to assume that passages of auctorial self-awareness in the poem, especially the apologia pro vita sua of C 5.I-IO4, constitute Piers Plowman's dramatization of attacks upon Piers Plowman against which Piers Plowman then defends Piers Plowman. That is possible; but other sorts of such "work" make Will very irritated, and given his attack on frivolity it is certain that if he had written something like William of Palerne, no matter how much others might enjoy and admire the results, it would have eaten at his conscience: "Japares and jangleres, Judas childrene, / Founden hem fantasyes and foles hem make, / And han wytt at wille to worche yf hem lust" (A Prol.35-7).

Thirty lines before this "janglers" passage, just after donning his sheepskin, Will had said, "Y was wery forwandrit and wente me to reste" (A Prol.7), a line that directly echoes one such fantasy: William of Palerne, whose protagonists were "Al wery for walked, and wold take here reste" (2236). ${ }^{4 \mathrm{I}}$ That parallel might well be conventional, but the one between the romance's "but sche a bere were," pertaining to its most memorable characteristic, and the dream vision's "as y a shep were" cannot be thus explained. If Langland had translated Guillaume de Palerne, Will's taking on of the penitential state by becoming sheep-like would seem to recollect, for the purpose of correction, "the wantonness or heat of youth" as manifested in his romance about the two young lovers. In this scenario the benevolent werewolf, guardian of Melior and William, would be transformed into the errant beasts both of the poet's own past and of those external threats (usually, the friars) that show the results of such psychical disorder within both the individual and society's institutions. ${ }^{42}$ As a sheep, Will would now be a penitent, but also a potential victim of such wolves, no longer the noble protectors they were in William of Palerne.

If the opening lines of Piers Plowman do constitute the first instance of Langland's series of retractions or apologies throughout the poem in all its versions, they participate in two prominent strategies by which medieval authors distanced their works from earlier, potentially sinful ones. First is 
"the topos of regret" described by Olive Sayce: "it is extremely common for an author to begin a religious work by repenting of the folly of his youth, the misuse of his talents and more specifically of his sinful worldly writings." ${ }^{43}$ Thus does Alcest enjoin "penaunce" upon Geffrey, in the Prologue of Chaucer's Legend of Good Women, for the works he made "Whil he was yong" (Text G, 469, 400). ${ }^{44}$ For a Langland who had written William of Palerne, this topos would have been especially appropriate in light of the second such strategy, which targeted works of its genre in particular: "A long sequence" of English poems of the Edwardian period (c.I270-I370), "all of them sober religious writings, begins with a rejection of romances," observes Ralph Hanna. "The poems propose other identity models, other ways of becoming, and provide variously alternative histories." 45

My proposed reading of the Prologue's opening, in sum, directly addresses the problems of line 2 that remain in particular need of explanation; accords with the poem's continual emphasis on penance; and suggests concrete ways in which Langland's great work invokes important strands of medieval poetics. None of this is evidence that Langland wrote it, but it does show that the refusal even to wonder whether William's surname was Langland, on the grounds that these poems have nothing in common, is misguided.

\section{Revelation and Atonement}

Disguise comes to the fore again in the poem's subsequent dramatization of the Atonement, which likewise invokes the romance tradition, in a way that reinforces the role of the archive in humanity's salvation. Emily Steiner establishes an important and useful context for Piers Plowman's narrative of the Atonement: the Ancrene Wisse's allegorization of Christ the King's wooing of the soul of humanity via a "progression of documents" that "closely follows a common late twelfth-century practice in which English and French kings negotiated peace treaties and marriages by dispatching envoys with oral messages and letters close. These letters protected the envoys and attested to their reliability." ${ }^{46}$ In this popular early-thirteenth-century guide for anchorites, Christ sends the patriarchs and prophets to his soul with "leattres isealet" (letters close), and then follows them up by coming himself with "leattres iopenet" (letters patent) in the form of the gospels. ${ }^{47}$ So too does Piers Plowman dramatize such a progression in B passus $17-18$, beginning when Spes (Moses) seeks the knight who "toek me a maundement upon pe mont of synay" and who 
"hath pe seel to kepe" for Spes's unsealed writ (17.2, 5), and including Love's sending the New Testament as letters patent to Lady Peace: "Loo! here pe patente" (I8.I86). ${ }^{48}$

William of Palerne is among the list of romances that employ such motifs. Here they are not allegorical. Near the conclusion of the poem, William commands "menskful messageres, ... pe grettest lordes of pat land" to bear "loveli letteres" that will invite the emperor of Rome to the wedding of William and the emperor's daughter Melior (4808-9, 48I2). Upon hearing their message, the emperor excitedly calls for a clerk, who then "undede po letteres, I And fond as pe messageres hade munged before" (4846-7). ${ }^{49}$ As in the historical practice allegorized in the Ancrene Wisse, these sealed letters testify to the reliability of the bearers of the spoken message: "Panne wist pemperour wel pat pei were treuwe" (4850), the narrator remarks in a statement with no equivalent in the French (Guillaume 8460f). ${ }^{50}$ This episode, in emphasizing the dramatic role of the letters close, suggests a parallel between the material properties of these letters and the spiritual state of the poem's actors in a very Langlandian way. The unsealing of the letters effects the revelation of a lifetransforming truth that enables an atonement of sorts: "And whanne pemperour hade herd how hit ferde" with his daughter, "He was gretteli gladed and oft God ponked / Of pe fortune bifalle of so faire an hende" $(487 \mathrm{I}-3) .^{\text {II }}$ This connection between the unsealing of the letters close and the act of revelation, broadly conceived, is fundamental to the operations of both the French and English poems. Guillaume de Palerne opens with the claim that "bien repont son sens et pert / Qui nel despont apertement / En la presence de la gent" ("he truly conceals and wastes his knowledge, / When he does not reveal it openly / In the presence of the people" [4-6]), a sentiment that, even if William did not translate it (these lines would have been in the now-lost opening of his English text), he definitely took to heart.

In William of Palerne animal skins hide the protagonists' human nature; in Piers Plowman it is human nature itself that hides Jesus's own given nature, his divinity, in its stunning dramatization of the Atonement. This disguise effects the redemption, and makes manifest the incipient role of disguise in the documentary poetics of these passus. Just as Christ the King's message to humanity remains hidden until the New Testament makes it patent, so does his true nature remain unknown to the devil until the Harrowing of Hell reveals it to devastating effect. "This Jesus of his gentrice wol jouste in Pers armes," explains Faith (Abraham): 
In his helm and in his haberion, humana natura;

That Crist be nat yknowe here for consummatus deus

In Pers paltok the plouhman this prikiare shal ryde,

For no dynt shal hym dere as in deitate patris. (B I8.22-6)

This reference to Christ's "arms of human nature," which prevent others from recognizing his divinity, sets the stage for the ensuing episodes both of his joust with the blind Jew, Longeus, who, when Jesus's blood "unspears" his eyes, immediately repents his actions (18.78-86), and of the Harrowing of Hell, in which the conqueror taunts Lucifer that "in liknesse of a lede" he has beguiled the beguiler (I8.356). The theological issue at stake is the notion of the "devil's rights" over humanity, gained when Adam ate the apple, but in Langland's poem forfeit now that Jesus's disguise has fooled the devil into jousting with him and thus into attempting to claim the soul of God himself..$^{52}$

As Wilber Gaffney says, "Christ is here represented as following the custom fairly well known in the Middle Ages - at least in the chivalric romances - according to which a renowned and formidable knight rides to a tourney in disguise so that his adversaries will not recognize him and consequently decline to encounter him in the lists." ${ }^{33}$ But that custom does not extend to the invocation of the "devil's rights," which is unique to Piers Plowman. Medieval explanations of this theory of the Atonement, after all, usually employed the sorts of images we might expect in a story of trickery, as in this figure by Augustine: "The cross of the Lord became a mousetrap for the Devil; the death of the Lord was the food by which he was ensnared." 54 It is quite a leap from mousetraps to armor. ${ }^{55}$ If Langland had written William of Palerne when he turned to this portion of his poem, though, things begin to fall into place. Romance and disguise are the stuff of the unsanctified works for which the poet himself seeks atonement; the centrality of disguise to the "devil's rights" theory, and of romance to the Christ-knight motif, led him to pull all these strands together in his own treatment of the Atonement. The Christ-knight's disguise might not be a fishhook or mousetrap, but, if my speculations are right, it served Langland's purpose quite well by recalling William of Palerne's own stories of disguise and chivalry.

This romance, whoever wrote it, looks forward in interesting ways to Langland's depiction of the Christ-knight, developing its emphasis on identity and disguise by exploiting the dramatic possibilities presented by the military characteristics of the romance tradition. In their waning moments in deer costumes, the lovers wonder why a hart that they find 
close by in the park does not flee. Melior assumes it must be asleep, while William takes its stillness as evidence that their disguises have succeeded: "Wist it wisli whiche bestes we were, / It wold fle our felaschip for fere ful sone" (3118-I9; Guillaume 5200-2). The hart is actually the queen of Palermo, William's mother, come in disguise to bring the lovers into her community so that they can help defend her city against the onslaughts of Spain. Friend and foe alike subsequently know William only by his shield of gold painted with a werewolf (32II-24, 3433-7, 3570-6), "But witterli what he was wist non of alle," as the narrator says about the people of Palermo, a remark very close to William's about the strange hart (3327; Guillaume 5586). The king of Spain even wonders whether "It is sum devel degised" who is slaying his men (3888; Guillaume 6724-5 does not refer to "disguise"), which reverses, some decades in advance, Piers Plowman's depiction of Jesus in human disguise when battling the devil. Only after the war does Alphouns, now disenchanted of his werewolf's body, point out that, although "pis kud kni3t with his clene strengpe" has in effect liberated the city, "3it wot non wiseli wennes he come" (46I2, 46I5; Guillaume 8084). Alphouns proceeds to unveil William's identity (that is, his parentage), showing that he has just helped the warrior's mother, and enabling the sequence of romance-concluding marriages and their attendant epistolary exchanges to proceed.

These parallels do not provide evidence for common authorship. But if common authorship is assumed for a moment, they do render newly intelligible a number of problematic episodes of Piers Plowman. The sheepskin of its opening lines would be an epitome of the most memorable portions of that romance, when Melior and William look like bears or deer; the dream vision's procession of documents would allegorize the romance's secular, narrative version of atonement via letters patent; and the Christknight of its later passus would invoke the climactic battle scenes of the earlier poem, after which things become one again within its aristocratic and chivalric world. Perhaps William of Palerne is not needed to explain any of these episodes taken alone, but Langland's authorship of the romance would elucidate both the otherwise jarring roles of disguise in the poem's working through of penance and the connection these passages forge between disguise and atonement, and between each other.

\section{Conclusion: prominent patrons and poetic models}

This possibility should prompt fresh attention to certain historical circumstances regarding the milieu(x) of the William(s). If indeed Langland wrote 
William of Palerne, the example of John Audelay, another penitential poet from the West Midlands, who might himself have read Piers Plowman, helps to fill out his social milieu as a young man. ${ }^{56}$ On Easter Sunday I4I7, as Michael Bennett has discovered, Audelay was implicated in a notorious assault by his patron, Richard Lestrange, on an enemy in London's parish of St. Dunstan's-in-the-East; in his later years, having become a chantry priest at Lestrange's Haughmond Abbey, he put together a compilation of his penitential poetry, which seems both to respond to this traumatic experience and to be intended to replace whatever youthful secular poetry he had written, just as the poet who, so I speculate, wrote the opening penitential lines of Piers Plowman ${ }^{57}$ Still more pertinent is Bennett's point that, "In the study of the poets of the West Midlands fuller acknowledgement is going to have to be made to the remarkable cohesiveness of the upper échelons of English society at this time, and to the extraordinary mobility manifest among all the sections of the community." ${ }^{8}$ Langland was intimately familiar with communities of the West Midlands and London regions. Audelay's career as a chantry priest who dabbled in pious verse in his advanced years, and had traversed England from London to Shropshire as a younger man, might well have been foreshadowed a few decades earlier by, and perhaps even modeled upon, the older poet's career.

Langland had a similarly itinerant career under the auspices of a powerful family. Robert Adams has pursued this probability furthest, proposing as the poet's most likely patrons Thomas Beauchamp, eleventh earl of Warwick (1314-69), and then his son, also Thomas, the twelfth earl (d. I4OI), who travelled to Brittany in 1368 in the company of one "William Rokele." 59 Adams identifies "complex, interlocking relationships" among the Beauchamps, Rokeles, and Despensers, ${ }^{60}$ but of course that probably applies to all aristocratic families in fourteenth-century Britain. For what it is worth, then, we can add that the elder Thomas Beauchamp was third cousin of the man who commissioned William of Palerne. Indeed the Bohuns, as holders of earldoms, had much more in common with the Beauchamps than did the Rokeles. The respective fathers of Thomas and Humphrey, and second cousins to each other, were Guy de Warwick and Humphrey de Bohun, fourth earl of Hereford, two of the three barons who kidnapped Piers Gaveston and oversaw his execution in 1312. ${ }^{61}$ Thomas himself was a founding member of the Order of the Garter in 1349, and was joined almost immediately by William de Bohun, Humphrey's older brother. ${ }^{62}$ Their common ancestor was Humphrey de Bohun, second earl of Hereford (d. 1275). ${ }^{63}$ It is not 
difficult to imagine scenarios that could have brought the poet William, if under Thomas Beauchamp's patronage, to the attention of his cousin Humphrey before 136r.

The connection with one or both of these households is intriguing in light of another, explosive discovery by Bennett: that one "Willelmus vocatus Longwyll" is among the dozen men who in 1385 stood accused of aiding and abetting the murder, by the half-brother of Richard II, of Sir Ralph Stafford, son and heir of the earl of Stafford. ${ }^{64}$ This occurred as men from all over England were gathering at York in preparation for the king's expedition to Scotland, including Thomas Beauchamp, twelfth earl of Warwick, who led a retinue. Indeed the murder victim was Thomas's nephew. ${ }^{65}$ While Bennett allows that there must have been many "Long Wills" in fourteenth-century England, he speculates that this is Langland on the grounds that "Long Will" is how the poet signals his authorship of Piers Plowman (B I5.152) and, crucially, that this name is accepted by the men making a formal record of a serious crime involving two important noblemen. If this is our man - another big "if," to be sure - it is intriguing to note that among the eleven who joined Long Will on the list was Warin Waldegrave, whose brother Sir Richard, prominent member of Parliament, spent most of his life in the service of the Bohuns (and who will reappear in Chapter 2). ${ }^{66}$

Adams's and Bennett's proposals regarding the identity of Langland are squarely in the subjunctive mood: either, both, or neither might be true. But such uncertainty is no cause not to keep wondering. Whether they explain how the poet of William of Palerne came into contact with Humphrey de Bohun, that poet would have found in him much both to irk and to inspire. Langland and Audelay are "orthodox critics of ecclesiastical covetousness, whose principal target is the friars," while Humphrey, by contrast, was among England's greatest benefactors of the Austin friars, in whose London church he would be buried. ${ }^{67}$ Among the members of his household were an Austin friar who went on to oversee the production of "the most important group of English illuminated manuscripts of the second half of the fourteenth century," 68 and perhaps John Erghome, another Austin friar, bibliophile, and author of a commentary on John of Bridlington's Prophecy (c.1363). Although this work is dedicated to Humphrey's nephew and heir Humphrey, seventh earl (who was patron of Richard Waldegrave), it seems probable that the sixth earl himself probably commissioned it. ${ }^{69}$ Erghome witnessed the catalogue of the Austin York library in 1372, to which he would eventually donate much of his enormous collection of books, a library with which one copy of Piers Plowman, 
now in CUL MS Dd.i.I7 (c.1400), should perhaps be associated. ${ }^{70}$ His commentary shares with Piers Plowman a propensity for the Oxford-style intellectual riddling of the late fourteenth century. ${ }^{71}$ One wonders, given all these associations, potential and real, with Erghome and the Austin friars, whether Langland might have been thinking of himself as something of an Austin friar - of, that is, the order of the Friars Hermits - in the opening lines' reference to his dress as a hermit. ${ }^{72}$

Any connection of Langland to this milieu, or to those of the Beauchamps and Waldegraves, is of course very speculative. Yet any discussion of an entity called "Piers Plowman B" with wide readership in the 1380 s is just as speculative, but less willing to recognize as much. This is the entity at the heart of Langland studies for well over a century, despite the absence of any manuscripts from that era, evidence of minimal copying then, and powerful evidence that the archetype from which all copies descend took on many readings and passages from the $\mathrm{C}$ version of $c .1390 .{ }^{73}$ Attribution is not confined to authorship, or speculation to the murky ground covered in this chapter. So too, as the next two chapters will argue, the assumption that everything found in the archetypal traditions, or in the "best text" of any of them, is authorial unless mangled is a gesture of faith not intellect, an act of speculation no less than is any well-reasoned conjectural emendation.

Recognition of those circumstances might not lead to the large-scale embrace of the notion that William's last name was Langland, but it will at least lead to a fairer assessment of the place of attribution and speculation in the assessment of the Middle English archive. This chapter has implicitly touched on the question of where the poet of William of Palerne undertook his project; as we will now see, the question of localization is intimately connected to the sorts of questions regarding the fabrication of the Langland archive raised by this analysis of attribution. Localization is in effect a substitute for authorial attribution, one that finds the external authorization of meaning in place rather than an individual mind, and as such just as thoroughly implicated in circular reasoning as is the attempt to distance the poet of Piers Plowman from anything so undignified as the story of William and the werewolf. 


\section{Localizing Piers Plowman C: Meed, Corfe castle, and the London Riot of 1384}

"Liminal, emotional, and indeed erotic": few constituents of the medieval literary archive, certainly not authorial attribution, can hope to be described in the terms that David Wallace assigns to place, an entity to which are attached "heightened states of emotion: the pleasures of being fully in place; the pains and travails of being out of it." While Langland is neither a celebrator of hearth and home nor a follower of Mandeville, he is particularly attuned to other of the pleasures and pains specific to place, especially as it determines the nature of the individual's quest for St. Truth. Take Wit's invective against the restlessness of the religious, in lines unique to $\mathrm{A}$ :

Y have lerned how lewid men han lered here children
Pat selde mosseth pe marbil pat men ofte treden,
And riht so be romeris pat rennen aboute
Fro religioun to religioun, recheles ben pei evere;
Ne men pat conne manye craftes, clergie it tellep,
Thrift oper thedom with tho is selde yseyen:
Qui circuit omne genus in nullo genere est. (A I0.IO3-8 $\alpha$ )

This inversion of the cliché that it is the rolling stone that gathers no moss reinforces the near-eroticism of place: here, it is the stationary marble that stays clean, an image that evokes in the reader a tactile, pleasurable sense that no reference to a monastery or guildhouse could easily have provided, even if it is what Wit had in mind.

Place's role in the production of Piers Plowman, too, has long determined, or at least reflected, its meaning in the eyes of its modern readers. The A version's content and form are somewhat tentative, rendering its extant manuscripts' localization to the hinterlands unsurprising and appropriate. $\mathrm{B}$ is the urbane and bold one: it belongs to London, where indeed that version's earliest and most important manuscripts were produced. And the great nineteenth-century editor Walter W. Skeat asserted as a "fact" the 
notion that "the poet grew more conservative in his ideas and more careful in his expressions as he grew older," which well fit his proposal that Langland retired to his home region of Malvern to compose the final, $\mathrm{C}$ version. ${ }^{2}$ A modern articulation of this thesis appears in Steven Justice's influential identification of the "principled evasion" of C's politics in the wake of the Rising of I38I. ${ }^{3}$ The fact that the "best" C-version manuscripts, those of the so-called $i$-group, "form a dialectally cohesive South-West Midland group," as M. L. Samuels concluded in an influential study, has supported this claim, ${ }^{4}$ while the more recent localization of those copies' production to London has led to the converse conclusion, "that Langland remained resident in London during this process, and that his holograph was released to the London book trade rather than to a number of local Worcestershire scribes."

To correlate certain of the extant manuscripts with the poet himself is to believe that the archive has already interpreted itself, as it were. Yet those copies of Piers Plowman embody no "evidence," per se, for the location of the poet when he was writing. The only manuscripts that might have done so - the holographs - are gone, and even they might not have provided any clues. If the archival support for the localization of Piers Plowman C, upon which this chapter focuses, is absent, then we need to turn to the poem itself: likewise the product of assumptions that include the notion that Langland had retreated to Malvern in the wake of the Rising to write a clearer, perhaps duller, certainly safer poem. These assumptions, I will suggest, have prevented recognition of what otherwise would have appeared to be clear responses to the explosive events that rocked the London streets in February I384. Thus, while one of my major goals is to argue positively for London as site of the production and earliest transmission of the $\mathrm{C}$ version, this chapter will also be advocating the more fundamental point that our methods of localization to date, including those that happen to result in a London localization for $\mathrm{C}$, have been circumscribed by a commitment to other beliefs that in effect answer the question before it is asked. However much we want the archive to serve as an external guarantor of, or a check on, our response to the poem itself, subjective acts of literary interpretation must at the least accompany, perhaps trump, the supposedly sounder archival approach on which professional academic scholarship since the days of Skeat has rested its claims.

\section{In London and upon London}

One reason for the particular interest in the localization of $\mathrm{C}$ is that Reason, Conscience, and Will himself are heavily invested in the topic as 
well, the latter answering the former two interrogators, as most readers have it, with the assertion "And so y leve in London and opelond bothe," "in London and the country too." This phrase, perhaps more than any other in Piers Plowman, has served as a touchstone for modern scholarship of the poem in all its versions, of the poet, and even of the alliterative corpus at large. It both generates and is the culmination of Steven Justice's account of Langland's "principled evasion" of the urban evils associated with $\mathrm{B}$ to the conservatism of $\mathrm{C}$ and the West Midland countryside (see note 3); is central to Anne Middleton's argument that the apologia pro vita sua dramatizes an interrogation under the 1388 Statute of Laborers, and as such is at the core of all recent discussions of C's dating: "Will's reply thus appears to be an effort to defeat the statute's most fundamental premise: that everyone ultimately belongs to a single local habitation"; 7 serves as the main title of Simon Horobin's study of the production of some C manuscripts; and provides the conceit of Christine Chism's claim that the alliterative romances at large "imaginatively claim dual citizenship of 'London and opelond bothe'.'

Yet the chances are that fewer than one in four medieval readers of $\mathrm{C}$ encountered it, if extant manuscripts are representative of that version's life: four of seventeen $\mathrm{C}$ witnesses, $\mathrm{XYJU}$, read opelond, while the remaining thirteen, comprising the majority P-group manuscripts, attest: upon londoun $\mathrm{KGN}$; on londen PRVAQS; in londone $\mathrm{E}$; by londoun $\mathrm{F}$; out of londone $\mathrm{M}$; up pe londe D. ${ }^{9}$ As George Russell and George Kane say, "either of the main variants would pass muster if unchallenged." ${ }^{\text {IO }}$ Endorsing Skeat's interpretation of the P-group reading - "'I live in London, and upon London,' i.e. upon the work which London affords" ${ }^{\text {"I }}$ - they propose as Langland's original up london, which could easily have generated the scribal alternative for the very reasons that it appeals to modern critics as well: "Assuming originality of upon or up london, uplond, 'in the country,' might suggest itself as in balance with preceding in london; or knowledge of the poet's actual circumstances; or the suggestion that he 'moved about' in 49-5I following might have prompted substitution." "I2 Fortunately, users of editions, unlike editors of hard-copy volumes themselves, need not decide either way.

It is appropriate that a single contested phrase about the dreamer's location has determined so much thought about the whole poem's localization. This serves as a reminder of how reliant such large claims often are on relatively insecure beliefs about local issues, as it were. The set of assumptions that issues in opelond's centrality has its origins, as does so much in Langland studies, in the work of Skeat, who based his belief that Langland retreated to Malvern to engage in his final, "conservative" 
revision on three indications. The only one to retain its power is the South West Midlands dialects of the "best," $i$-group manuscripts of the $\mathrm{C}$ tradition, ${ }^{\mathrm{I}}$ forging a connection between any extant manuscripts and the author that over the past few years has only grown stronger, with such claims as that Huntington Hm I43, MS X, has "some direct connection to the author" proliferating. ${ }^{\mathrm{I}}{ }^{4}$ Such affiliations of certain surviving copies with the poet and his locale have moved from Skeat's impressionistic tone to an almost scientific one in the wake of the publication of the Linguistic Atlas of Later Medieval English in 1986, which signaled the arrival of dialectology as one of most powerful tools of Middle English studies. ${ }^{\text {I5 }}$ Using securely localizable texts as their anchors, practitioners are able to determine with a fair degree of certitude the region in which the text of a given manuscript's language was formed. That site is not necessarily where the text was copied, since both authors and scribes traveled.

So much is clear enough, and sophisticated tools enable critics to distinguish the various layers of dialects in texts far removed from their origins. The difficulty arises in determining the extent to which scribes left the marks of their own language on their texts, as opposed to faithfully reproducing the language of their exemplars even where that language is in an unfamiliar dialect. Samuels, assuming that scribes left heavy traces as a matter of course, believes it would be "very strange indeed if each C-MS (if written in London) had found a south-west Midland scribe"; ${ }^{16}$ while Horobin finds evidence of the contrary, and thus locates the $i$-group manuscripts to a circle of London scribes who were careful to transmit their copies' West Midlands dialect, a claim that has led advocates of Samuels's earlier, supposedly "well established" localization of C to Malvern to recant that position: the suggestion "is not well founded."

In such dialectal studies, some distinctions are constantly, and appropriately, identified and maintained: those between authorial and scribal dialects, and between the sites of linguistic formation and of the production of later manuscripts. But that level of care has not extended to two other, no less important sites, which are collapsed as a matter of course in this Malvern vs. London debate: the site of the work's original production and that of its later dissemination. The culprit is the concept of textual "superiority." For both proposed sites of C's production, Malvern and London, are the result of the determination of the localization of "the 'better' $i$-group" as opposed to that of "the inferior p-group." "T The logic, although never articulated as such, seems to be that "that the C-text copies, too" - that is, the "better" ones - "were almost certainly first released in London," as Andrew 
Galloway has said, "their western dialect a sign of a shorter and perhaps more explicitly authorized London textual history than the A or B copies."

Still lacking is any explanation of why a manuscript's "quality" serves as an index to the location in which its original ancestor was produced. Perhaps those who assume such a correlation believe that the P-group “'is sophisticated and given to expansion,' and on comparison with the other groups proves to be lower down the chain of transmission and therefore furthest from the author's original," as Bessie Allen believed (here summarized by Charlotte Brewer). ${ }^{20}$ But Russell and Kane have now shown that "there are about 520 family errors in P as against 470 in $\mathrm{X}$," which means, first, that the X-group is only about Io percent "better" than the P-group, and second, that both groups introduced many errors from the start: the latter is not "lower down the chain of transmission," that is, an offshoot of the X-group, at all. ${ }^{21}$ Both groups' ancestors made copies of the $\mathrm{C}$ archetype. And in any case the earliest surviving manuscripts of both the $\mathrm{X}$ - and $\mathrm{P}$-groups are roughly seven generations of copying removed from the holograph. In Figure 3, in Russell and Kane's analysis, are the lines of transmission. ${ }^{22}$ The earliest A copies, too, are separated from that version's holograph by seven generations, which is about double the number between the earliest $\mathrm{B}$ copies and that version's holograph. ${ }^{23}$

Yet the belief that the quality of MS X shows it to be closer to Langland than was even the ancestor of the P-group, its own greatgreat-great-great-uncle, has become the foundation for all discussion of

\begin{tabular}{|l|l|}
\hline $\mathrm{X}$-family subarchetype & Pangland's C holograph \\
\hline$i$-group (branching away from $\left.\mathrm{TH}^{2} \mathrm{Ch}\right)$ & P-group ancestor $(\mathrm{KGN}$ branches away) \\
\hline $\mathrm{D}^{2}, \mathrm{UD}$, ancestor of major $i$-MSS & $\begin{array}{l}\text { ancestor of }\{[(\mathrm{PE})(\mathrm{VA})] \mathrm{RM}\} \text { (QSFZW } \\
\text { branches away) }\end{array}$ \\
\hline $\mathrm{P}^{2}$; ancestor of $[(\mathrm{XYH}) \mathrm{J}]$ & exemplars of PEVA and RM \\
\hline $\mathrm{J}$, exemplar of $\mathrm{XYH}$ & $\mathrm{R}, \mathrm{M}$, exemplars of PE, VA \\
\hline $\mathrm{X}, \mathrm{Y}, \mathrm{H}$ & $\mathrm{P}, \mathrm{E}, \mathrm{V}, \mathrm{A}$ \\
\hline
\end{tabular}

Figure 3 Lines of transmission of the two C-text MS families 
the $\mathrm{C}$ version's localization. By this logic, Langland could have been in Cambridge c.I870, when Skeat took a faithful copy from MS J, producing Cambridge, Trinity College MS 536 as he prepared his edition of the $\mathrm{C}$ version. However far removed in place or time, scribes could faithfully copy texts. The site of any given manuscript's production, in sum, says nothing about where the poem's author was when he wrote it. It is no surprise that copies stayed in that location, whether in London or opelond, but the only way to reverse the terms is, as George Kane said about the methodologies of attribution, already to know the answer to the question.

\section{Many sundry sorrows: C 3.87-II4 and the riot of February 1384}

One potential source of evidence for the localization of Piers Plowman $\mathrm{C}$ more reliable than dialect might be the transmission history of the $B$ version. Nearly all readers agree that $B$ is a London production, and many of its earliest extant witnesses, observes Robert Adams, "were almost certainly produced in the same place in London, either by a group of Langland's friends or by their immediate successors." ${ }^{24}$ If I am right to believe that passus 19 and 20 came into the B tradition from Langland's $\mathrm{C}$ papers, then it would seem very probable that $\mathrm{C}$ must have been circulating in London by around $1390 .{ }^{25}$ The question of whether the Londoner Thomas Usk, beheaded in $\mathrm{I} 388$, referred to the $\mathrm{C}$ version in his Testament of Love remains open. ${ }^{26}$ In turning from external to internal indications of Piers Plowman C's site of production and earliest readership, one will immediately be struck by the fact that, as James Simpson notes, "the emphasis changes from Langland as an uplandish figure in the B-Text to Langland as a Londoner in the C-Text (a change consonant with three extra 'London' passages in that version)." ${ }^{27} \mathrm{He}$ refers to the apologia pro vita sua (5.I-IO4), which occurs, says the dreamer, "whan y wonede in Cornehull" (I); I6.286-97, in which he says "Ich have yleved in londone mony longe 3eres" (288); and 3.87-II4, an exhortation to mayors not to enfranchise false traders. Even so, the presence of these passages has never led critics to assume the necessity of their composition or reception in London.

Yet the final of these extra "London" passages, so I will now argue, responds directly to explosive events on the streets of London in February 1384. That might suggest, but does not necessitate, Langland's presence there; what turns this possibility into a probability is that the passage seems to assume the same knowledge in its readers: if he were referring to 
an episode that was not common knowledge among his audience (as would likely be the case in the West Midlands, where the bickerings of London's mayors and aldermen would not have been foremost in readers' minds), we might expect a more explicit treatment. The Meed episode of both the A and B versions leading up to this point features a standard moralistic invective against "regraterie," that is, "buying up food in one market and selling it at an enhanced price in another, which was forbidden by civic custom. ${ }^{28}$ In C, though, the narrator's warning becomes part of a full-scale program, in which the biblical prophecy is not just an abstract moral, but a real and terrifying event fulfilled on city streets:

Many sondry sorwes in citees falleth ofte

Bothe thorw fuyr and flood and thorw fals peple

That bygyleth goode men and greveth hem wrongly,

The whiche crien on here knees pat Crist hem avenge,

Here on this erthe or elles in helle,

That so bigileth hem of here goed, pat God on hem sende

Fever or foule evel other fuyr on here houses,

Morreyne or other meschaunce.

(C 3.90-7)

Many times, the narrator continues, the saints beseech our Lord and Lady, on behalf of the suffering innocent, to allow sinners to have their penance on earth, rather than the pains of hell afterwards (97-IOI). The crucial part of this addition comes next, in the $\mathrm{C}$ reviser's elaboration of the pain suffered by the innocent via the actions of a single sinner:

And thenne falleth ther fuyr on fals mennes houses

And goode mennes for here gultes gloweth on fuyr aftur.

$\mathrm{Al}$ this have we seyn, pat som tyme thorw a breware

Many burgages ybrent and bodies perynne

And thorw a candle clemynge in a cursed place

Ful adoun and forbrent forth alle pe rewe. $\quad\left(\mathrm{IO}_{2}-7\right)^{29}$

The logic and imagery here look forward, as it happens, to an argument for the legitimacy of the medieval archive by a Reformist and serious reader of Piers Plowman, Stephan Batman, a few centuries on:

He is no wyse man pat for the haveng of spiders. scorpions. or any outher noysom thinge in his howse will therefore set the whole howse on fier: for by that meanes, he disfornisheth himselfe of his howse: and so doo men by rashe borneng of ancient Recordes lose the knowledge of muche learnenge / there be meanes and wayes to presarve the good corne by gathering oute the wedes. ${ }^{30}$ 
The parallels indicate how deeply ingrained are the impulses to burn and to archive, whether the agent is a zealous Reformer or God himself, angry at the scorpionesque regrators whom, says Langland's narrator, mayors must keep in check:

Forthy mayres pat maketh fre men, me thynketh pat ze ouhten

For to spyre and to aspye, for eny speche of sulver,

What maner muster oper marchandise he used

Ar he were underfonge fre and felawe in soure rolles.

Hit is nat seemely, forsothe, in citee ne in borw toun

That usurers oper regraters for eny skynes zeftes

Be yfranchised for a fre man and have a fals name. (I08-I4)

The C reviser's whole performance bears an extraordinary resemblance not just to Batman's future work with Archbishop Parker, but also, much more immediately, to the Westminster Monk's account of an event that occurred on the London streets in February 1384, in which a supporter of John Northampton, mayor of London from I38I to I383, did indeed cry out for vengeance on the city streets, and lost his head for so doing. ${ }^{3 \mathrm{I}}$ This riot was the culmination of the unrest that followed the October 1383 mayoral victory of Nicholas Brembre, with the support of the victualing guilds, especially the fishmongers, over Northampton, aligned with the artisanal guilds. ${ }^{32}$ On the evening of February 7, 1384, says the Monk, Northampton's dinner companion was the young Thomas Mowbray, who asked Northampton to gather some friends that evening and join him at Whitefriars, where his brother had been buried a year earlier. ${ }^{33}$ Northampton arrived at Whitefriars in the company of some four hundred of his supporters in the artisans' guilds, still angry at the election of Brembre, who had the support of the fishmongers and other victualing guilds. Meantime, news of the gathering came to Brembre as he dined with some aldermen in the house of Sir Richard Waldegrave - whose brother was among those arrested together with "William vocatus LongWyll" for aiding and abetting the murder of Sir Ralph Stafford a year after these riots (Chapter I).

On the way back, the new mayor, in the company of forty of these partisans, fell in with Northampton, accused him of attempting to incite a riot, and arrested him. Brembre ultimately convinced King Richard to place Northampton under custody in Corfe castle. Four days later, John Constantine, a cordwainer, "excited, as some will have it, by a spirit sent by the Devil, careered through the streets of London urging the populace to rise against the mayor, whom he declared to be bent on smashing all those who supported John Northampton," writes the Westminster Monk. 
Constantine implied that Northampton's supporters "should suddenly surprise and destroy" Brembre; but "a righteous and merciful God,"

unwilling that the emergence of serious sedition in the densely populated city should lead, because of a single individual, to people's destroying one another, ordained a better course for events in choosing rather that one man should die than that the innocent blood of the many should be spilled. And so the cordwainer was arrested, and upon his conviction before all the leading citizens of spreading false statements, he was condemned to death in conformity with the law. By order of the court of aldermen his head was set above Newgate.

Constantine's head remained above Newgate for four years, until Brembre's trial in the wake of the Merciless Parliament. ${ }^{34}$

Two passages, both datable to the mid-I380s; referring frequently to London; focusing on mayoral responsibility, regratery, and divine justice in the streets; and emphasizing the need for civic authorities to act decisively so as to prevent punishment from raining down indiscriminately. Since no indications suggest that either author encountered the other's work, it seems most likely that Langland's revisions were prompted by the same events that brought about the Monk of Westminster's account. The passage in Piers Plowman C passus 3, these parallels suggest, is thus best read not as a general meditation on mayoral responsibilities regarding enfranchisement, applicable anywhere in England, but rather as an insertion inspired by the riot of 1384 . And unless the inspiration for this $\mathrm{C}$ addition was a late-night conversation between the prisoners Long Will and Warin Waldegrave the following year, the parallels canvassed above seem most easily explained as a London denizen's thoughts intended in the first instance for a London audience.

\section{In the castle of Corfe}

Brembre ultimately convinced King Richard to place Northampton under custody in Corfe castle: on its own there is nothing distinctive about that episode. But in the context of the $\mathrm{C}$ reviser's additions to the Meed episode, it takes on a different hue. For that matter, Piers Plowman C as a whole, its production and transmission, look different in light of Northampton's imprisonment in Corfe castle. The passage at issue occurs after the insertion discussed above. To this point C has tracked A's and B's presentation of the king's return from his privy council to confer with Meed, upon which he remarks that he has often forgiven her sins in the hopes that she will mend her ways. Then in $\mathrm{C}$ appear some new lines: ${ }^{35}$ 
In the Castel of Corf y shal do close the,

Or in a wel worse, wone ther as an ancre,

And marre pe with myschef, be seynte mary my lady. (C 3.141-3)

The identification of Corfe castle as Northampton's destination by both the Westminster Monk and the compiler of Letter-Book $H$ bolsters the likelihood that this was common knowledge on the streets of the city. ${ }^{36}$

We have already seen some of the difficulties standing in the way of recognition that these $\mathrm{C}$ additions pertain to London's factional politics of the 1380 os. Here another one comes to the fore, one that forces hard choices about the status of the "best" manuscripts of Piers Plowman: that in the received text "it is the treatment implied by the words as an ancre that is really important, not the place," as A. G. Mitchell remarked in an essay published in $1948 .{ }^{37}$ In this reading "the Castel of Corf" merely provides handy alliteration with "close," and does not carry any historical referent or particular meaning in the passage at all. Yet places in Piers Plowman, whether the Malvern hills or Corfe castle, deserve serious consideration before their importance is dismissed. With regard to Corfe, this is especially so given the powerful indications, some never noted before, that as an ancre, the phrase that led Mitchell and all subsequent editors to downplay the reference to Corfe, was probably not in Langland's text at all.

In I934, F. A. R. Carnegy proposed that the phrase at issue was "a gloss erroneously incorporated into the text": "So far from improving the line, the words 'as an ancre' overload it, and add nothing to the sense; or rather, they make nonsense, for anchorites did not live in castle dungeons." He speculated that perhaps a reader, prompted by "the thought of the solitude reigning in prisons and in anchorites' dwellings," wrote the phrase as a marginal annotation. While Carnegy does not say so in so many words, his theory finds support in the location of these three words: "in the MSS. of the $i$-group they come at the end of $l$. I4I; in those of the p-group at the beginning of $l$. I42," a circumstance suggesting that they "were tacked on to the end of $l$. I4I until the $p$-tradition, in its revision of the poem, transferred them to $l$. I42, and, by the addition of 'And marre pe with myschef' made two lines out of $l$. I42." ${ }^{38} \mathrm{He}$ concludes by noting that there is good precedent for this phenomenon of scribal incorporation of marginal glosses, ${ }^{39}$ Skeat's historical suggestions about the phrase are very weak, and the $p$-group's “'And marre pe with myschef' adds nothing to the sense, and seems to be a pretty certain example of padding." ${ }^{\circ}$ This proposal has garnered only one response: Mitchell's rejoinder that 
"the possibilities of interference and alteration are so numerous as to provide us with means of explaining away almost anything that does not readily commend itself to us." ${ }^{4 I}$ No modern editors have mentioned the possibility that as an ancre was a scribal gloss. ${ }^{42}$

Some compelling evidence, though, points to the plausibility of Carnegy's proposal. In received C 3.I4I-3, the term "anchorite" is singular, the sole referent to the religious life, and part of a quotation. By contrast, all six other appearances are in the plural and occur as a general referent, in juxtaposition with the terms "hermits" or "monks" and in the context of discussions of ethical matters of almsgiving, asceticism, or sex:

I. A/B Prol.28-30; C Prol.30-2:

As ankeres and eremites pat holdeth hem in here selles

Coveyten nozt in contrey to cayren aboute

For no likerous liflode here lycame to plese.

2. A 7.133-4:

Ankeres and eremites pat holdeth hem in hire selles Shullen have of myn almesse al pe while y libbe...

3. A I0.135-8:

For of here kynde they comen pat confessours ben nempnid, Bothe maydenes $\&$ mynchons, monkes $\&$ ankeres,

Kynges \& knyhtes, \& alle kyne clerkis,

Barouns \& burgeys, \& bondemen of tounes.

4. B 6.I45 / C 8.I46 (following two lines revised from B > C):

Ankerus and eremytes pat eten but at nones ...

5. B I5.213-I4:

For he lyveth nat in lolleris ne in londleperis eremytes

$\mathrm{Ne}$ at ankeres pere a box hangeth; alle swiche they fayten.

6. B I5.4I7-I8:

Ankerus and eremytes and monkes and freres

Peeren to apostles thorw hire parfit lyvynge. ${ }^{43}$ 
So too is the term's spelling of ancre in MS X, whose language is generally deemed closest to the poet's, ${ }^{44}$ unique: it is anker- in both other appearances. As Horobin shows, this manuscript's scribe was among a group "who were careful to preserve many of the features of dialect and spelling associated with the author"; ${ }^{45}$ if anker was indeed the author's spelling, then ancre at 3.I43 looks all the more like a scribalism taken up into the text and reproduced faithfully.

The case finds further support on the grounds of sense. Mitchell insists that it is "not relevant to point out discrepancies between the situation described by the poet, and the known facts as to purpose, method and place of the normal enclosure of anchorites. This is a special case and since the purpose and manner are different, we are hardly at liberty to argue from something out of the ordinary as to place." ${ }^{46}$ To bolster this remarkable stance he attempts to explain as an ancre in light of a theory of punishment: "sure that an experience of the loneliness and strictness of the anchorite's life would sober Meed and turn her honest," he writes, the king wishes "not merely to punish her, and dispose of her, but to reform her." ${ }^{47}$ In this reading as an ancre means "in the manner of an anchorite (which you will not really be)," but that is problematic. The seemingly analogous phrases, in which Will dresses "in abite as an heremite" (C Prol.3) or is "yclothed as a lollare" (C 5.2), are not really, as there can be no doubt there that "as (if I were)" is understood. ${ }^{48}$ And Langland could easily have avoided the ambiguity this approach necessitates: "as y a shep were" (Prol.2); "Thus is man and mankynde in maner of a sustanyf" (C 3.404); or, as in Fals-Semblant's boast in the Romaunt of the Rose, "Somtyme I am religious; I Now lyk an anker in an hous" (6347-8).

Questions of language aside, Mitchell is quite right about the king's desire to reform Meed, but has the means by which he can do so backwards: incarceration alone was sufficient for the purpose; enforced anchoritic enclosure impossible. "Penitential literature had early recognized that forced confinement could furnish opportunities for reflection upon past misdeeds and a change of heart," as Ralph Pugh says, "and this seems, at least sometimes, to have been the motive for imprisoning monks and nuns." 49 The case of a certain Matilda, an anchoress accused in 1389 of being "infected" with the harmful teachings of the Lollards, proves the point. When Matilda, under interrogation by Archbishop William Courtenay, responded not plainly but potius sophistire, he commanded "that the door of the recluse, in which the said Matilda was, should be opened, and that till his return he should cause her to be put in safe custody" - in "a veritable prison," says Mary Rotha Clay, for whose stone walls Matilda 
exchanged her own "under compulsion." ${ }^{\circ}$ Upon returning from her prison to her cell, Matilda recanted her heretical beliefs and the archbishop issued a mandate offering indulgences for those who came to her aid.

By contrast, anchoritic enclosure was the result, not the cause, of penance. It is the status from which Matilda is removed. The "essential feature" of the rite of enclosure "was the forgiveness of all the sins of the person about to be enclosed, a ritual death and burial, and the beginning of a new life in the anchorhold, beyond earthly sinfulness." "TI Thus no bishop or king could force a woman to become an anchorite. ${ }^{52}$ Those thus enclosed were no pariahs, a status Langland's king enjoins on Meed, but icons of holiness: "Admitted into the company of angels, they might then be allowed by God to see heavenly wisdom, to acquire true prophetic knowledge," in Anneke Mulder-Bakker's words. "They lived at an intersection of heaven and earth and incarnated the salvation that flowed to that place. With them people found a ray of happiness in this earthly vale of tears. The reputation of recluses was beyond question." 33

All of the above has engaged with the debate on the terms in which it was set, terms that would appear to remain in effect given the presentation of the data in all editions of Piers Plowman. But this is the product of an incomplete Langland archive. For these lines appear as well in another manuscript whose version has never been printed: National Library of Wales MS ${ }_{733} \mathrm{~B}$ ( $\mathrm{N}$ of $\mathrm{A} / \mathrm{N}^{2}$ of $\mathrm{C}$ ), ${ }^{54}$ whose $\mathrm{C}$ material, crucially, is a witness to that version's archetype independent of, and earlier than, the two major manuscript groups. ${ }^{55}$ Among the $\mathrm{C}$ matter conflated into N's A-text portion is this: "In pe castel of corf I schal done pe close / Or ellis in a werse wone by sent marie my ladye." Now, it is possible that the absence of our phrase here is the result of a scribal oversight. Yet to dismiss this new witness to the passage on such grounds would be to acknowledge the validity of Carnegy's approach to the $i$ - and $p$-traditions. Mitchell had objected that we have no right to such appeals unless the text is "mangled," 56 yet the sense of this text's reading is perfectly clear: precisely the one that Carnegy conjectured to be authorial even though he could not have known of this reading. ${ }^{57}$ It is true enough that the meter is faulty, the line's aa/xa scansion - castel, corf, pe, close - transgressing the aa/ax norm, but this is no stumbling block. It is simple enough to reverse the final two terms, as does Russell and Kane's text, and in any case the existence of passages like C Prol.95-I24, new material that barely attempts to maintain normative alliteration, should prevent too quick an appeal to such standards as prerequisites of authenticity. An aa/xy line like the second here could well have been a placeholder for the poet. 
It is an impossible situation, which no appeal to the authority of the received text over the presumptuous modern critic will help. As the opelond vs. up london dilemma also showed, this is a matter of judgment. The power of the archive will not suffice on its own. Mitchell's judgment that it is the treatment implied by the words as an ancre that is really important, not the place, has had an indelible impact both on the received text of Piers Plowman and, more important, on the process of localization via its occlusion of potentially (or, as I take it, actually) relevant evidence. Yet there are no good reasons to accept these words as authorial, many reasons to reject them, and concrete support for the alternative, that the king threatens imprisonment proper in Corfe castle, which fits the context perfectly. To date commentators have focused upon this location as the reputed site of Edward II's incarceration and possibly murder, though Skeat does as well suggest a connection with a thirteenth-century hermit who together with his son was hanged there for his evil prophecy to King John. ${ }^{58}$ Yet this is quite far, chronologically and thematically, from the drama of Piers Plowman C passus 3. The events of February 1384, by contrast, are both quite close and appropriate to the context, which, after all, is about mayors, meed, and punishment.

\section{Conclusion: toward a textual historicism}

If Piers Plowman $\mathrm{C}$ had already been determined to be a London production, would modern readers have proposed the existence of these allusions long ago? It is difficult to know the degree to which Langland's reputation as a poet "in opelond," far from London, fueled the notion that "the only difference between $\mathrm{C}$ and the earlier versions" in the matter of fair trading, as E. Talbot Donaldson said, "is C's elaboration, upon lines already laid down in $\mathrm{A}$ and $\mathrm{B}$, of a passage castigating dishonest retailers," nothing distinguishes $\mathrm{C} 3.87-\mathrm{II} 4$ from its $\mathrm{B}$ equivalent. More recently, James Simpson's argument that Langland engages intensively with London city politics, and particularly that he supported Northampton and the artisanal guilds, likewise says nothing about $\mathrm{C}$. Simpson cites the animosities of the 1380 os to lay out the situation, but, because of the supposed fact that at that point in time Langland was in the West Midlands, and the supposed "B" home of Simpson's textual evidence, he finds himself having to claim that it is instead the political situation of 1376 that is relevant. ${ }^{60}$

The passage at issue is the episode of the distribution of the gifts of Grace, which imagines the resolution of the trade rivalry between the artisanal and victualing crafts as a model for the renovation of the church: 
"Thouh somme be clenner then somme, 3e sen wel," quod grace,

"That all craft and connyng come of my zefte.

Loke pat noen lacke opere bute loveth as bretherne

And ho pat moest maistries can be myldest of berynge.

And crouneth Consience kyng and maketh craft 3oure styward

And aftur craftes consail clotheth 3ow and fedeth.” (B 19.252-7)

While Grace here imagines unity of "crafts," which Simpson plausibly takes to mean "guilds," nevertheless "Langland's picture is not innocent, or naïve, as read in the context of contemporary politics," he notes; "it is clearly angled in favour of the reformist party [of Northampton], in favour, that is, of 'Craftes Counseil'." The need to look elsewhere than the immediate historical context for this compelling claim, the Brembre/ Northampton disputes of $c .1384$, exemplifies the ways in which arbitrary elements of the Langland archive have forced its interpreters onto unnecessary detours. In this case, new evidence that passus $19-20$ entered B from C shows that Simpson's insight was even stronger than he could have known, and there was no need to look anywhere other than the obvious time and place, the London of $138 \mathrm{I}-4$, to make sense of Langland's engagement with regratery and the guilds. ${ }^{62}$

None of the above analysis is to say that the passage is "antiNorthampton," or that readers are to take these lines as a mini-allegory of London political strife. It would be a mistake to make too much of the connection of Meed and Northampton, not just because the king does not come off so well himself, but also because Langland exhibits so little interest in maintaining dramatic consistency in this portion of the poem. J. A. W. Bennett even proposed that the lines on regratery common to all versions "represent an officious scribe's intrusion or a fragment of a larger episodic discourse that was missing from, or never completed in, the $U r$-text," " a sense amplified in the C version: 3.77-II4, comments Derek Pearsall, "was never clearly related to the context in AB," with a repetition of line 77 at line IIs that "only emphasizes its digressive nature." ${ }^{64}$ The same could be said of I4I-6 on a smaller scale. The likeliest scenario for the production of $\mathrm{C}$ passus 3 is that, living in London in the 1380 s, Langland could hardly help seeing the pertinence of his earlier invective against shoddy victuallers and corrupt mayors to what was transpiring on the streets of the city, and that he wrote up some new passages on separate sheets, which could circulate independently of the poem, to be inserted into Piers Plowman as it stood at that stage. ${ }^{65}$ In this scenario early readers would have experienced the $\mathrm{C}$ version as a disjointed piece of work, with the narrative framework (for instance, Lady Meed's visit to Westminster) 
at times disappearing entirely while the narrative voice goes in other directions (as in the invective against victualers and irresponsible mayors).

Even if my proposal is the best explanation of the parallels between Langland's and the Westminster Monk's works, it is not inevitable. But such a qualification is necessary only because of the prior assumption that Langland was across the country in the I380s. What I am here urging, then, is the institution of a textual historicism, one that subjects all the available evidence for the manuscripts' histories, especially their texts, to critical scrutiny, rather than determining in advance that some are "better." The old controversy over as an ancre, and, even more so, the disappearance of that controversy, are cases in point. The abandonment of the subservience to copy-text also has the beneficial product of a sharpened understanding of the roles played by early scribes and readers. Even though "the glosses found in the MSS. are not often distinguished either by their brilliancy or by their lucidity," as Carnegy says, the instance here identified provides a newly apparent record of how one of its very earliest readers responded to the poem. ${ }^{66}$

My main goal is to promote recognition of the power accorded assumptions about the Langland archive that are somewhat arbitrary, the products more of certain stages in twentieth-century literary criticism than any analysis of the pertinent evidence. If, for instance, it were determined that my own proposals were no less arbitrary than those that led earlier generations to locate Langland where the best $\mathrm{C}$ extant manuscripts were produced, we would be left nowhere - literally, which is as it should be in such circumstances. This is just another way of saying that localization, which has so often relied on such technical methodologies as dialectology, is not something external and prior to interpretation, as we so often take the constituent elements of the archive to be: it is interpretation itself. 


\section{Latinitas et communitas Visionis Willielmi de Langlond}

An instant way to tell whether any given Middle English manuscript belongs to the Langland archive is to see whether it steadily incorporates Latin lines and passages of various length into its main English text. It is usually easy to tell, since they are visually emphasized via boxing, rubrication, or change of script to textura. Piers Plowman, of course, is not unique in featuring Latin prominently: Gower's Confessio Amantis does, in a manner quite different from Langland's, and the Clerk's Tale and the Wife of Bath's Prologue are surrounded by Latin glosses in many manuscripts, including Ellesmere and Hengwrt. ${ }^{\mathrm{I}}$ But because those glosses are marginal, they are not printed in the main portions of modern editions, their existence wholly eluding casual readers. Not so the Latin of Piers Plowman, which forces its Latin into its reader's consciousness. This prominence has led to a growing sense that Langland's relationship to Latinate cultures is a mark of his progressive originality. Sarah Stanbury wryly notes the critical trend according to which the poet was "something of a linguistic Robin Hood," "a folk-hero appropriating Latin texts and distributing them, in English, to the general populace," laying bare ecclesiastical secrets to vernacular readers of the poem as occurs within it as well. Others argue that Langland exploited the radical potential of the Latin itself, which "registers, and indeed is a register marker for, the dissonance and discontinuity" of Piers Plowman. ${ }^{3}$

While both of these approaches have been very productive, they rely on the extraordinary, downplaying the conventional. The conventional, though - the Bible, Cato, etc. - constitutes the overwhelming majority of Piers Plowman's Latin. As such, most of these tags "are detachable (and might have made their way into the text by way of the margin)," which is what led George Kane not to assign those lines distinctive numbers. ${ }^{4}$ Much of the Latin that editions print in their main texts does in fact appear in the margins of the manuscripts, especially the $\mathrm{OC}^{2}$ group of $\mathrm{B}$, and $\mathrm{F}, \mathrm{VA}, \mathrm{W}$, and $\mathrm{N}^{2}$ at various locations in the $\mathrm{C}$ tradition. ${ }^{5}$ The converse is true as well, with about thirty spurious Latin lines, some of which undoubtedly originated as marginal additions, appearing 
in the main texts of eighteen extant manuscripts. ${ }^{6}$ It is thus possible that, as with the as an ancre tag discussed in Chapter 2, some of the Latin lines assumed to be Langland's might have come into the main text from the margins, where they recorded early readers' engagement with the poem. A given line's appearance in an entire tradition means only that it was in that version's archetypal text, all three of which were at least two stages of copying removed from the holograph.

The possibility extends to lines extant in more than one version, as Langland might either have welcomed the new appearance of any given item and retained it in the next version, or failed to recognize it was not his own item in the first place. He merely initiated the process, which was simple enough to re-enact. For while not many readers this side of John But could write Langlandian verse with any facility, most anyone - at least, those who had studied grammar and listened to sermons, which I am assuming fits the bulk of Langland's audience, both real and imagined - could come up with an appropriate proverb. That is what margins are for. If Langland did indeed want to encourage his readers' participation in the production of his poem, he could hardly have chosen a better means. So when John Alford objects that Kane's line-numbering policy "devalues" the quotations by implying that they "are less important than numbered quotations, dispensable, perhaps not even authorial," well, except that Kane, if uncharacteristically, does not himself scorn this potential intrusion of non-authorial material into Langland's masterpiece.

Such treatment of the poem's multilingualism was a manifestation of the larger reality, not very clear from the received archive, that Latin provided the most immediate and accessible means for the medieval reader's engagement with and participation in Piers Plowman in its manuscript instantiations. We are accustomed to seeing Langland's poem as a triumph of the common tongue, a triumph to which even its treatment of Latin points: "Other languages are fought off; English is liberated and isolated." 8 But it was Piers Plowman's Latinity, precisely because of that language's status as the lingua franca of the literate, that enabled a substantial proportion of its audience most directly to come to terms with its message. This should not be very surprising, but the emphasis on the "English" of the "Middle English era" has kept Latin, precisely because of its dominance, on the outskirts. That dominance is too much even for Ardis Butterfield, otherwise committed to resisting the notion of English's separable character: "An even longer and better book would bring Latin properly into the picture as well, since in a sense this is the most important linguistic perspective of all."

This book, too, might be even longer and better if it gave Latin its due, but as it stands this chapter will contribute to Butterfield's project by presenting the evidence for the claim that Latin is how medieval and early modern readers 
were most likely to engage with Piers Plowman. This material is found on the flyleaves, margins, endpapers, and even the main texts of the poem's manuscripts and early printed editions, places that rarely figure in critical assessments of the poem's Latinity. Critics, interested almost exclusively in the texts that editors rely on and in general willing to grant that whatever is in the archetypal texts must be authorial, have made use only of the main texts, on the whole ignoring the other four of these locations. An emphasis on Langland's originality, and fabrication of an archive in that image, have, paradoxically, obscured one of his most original conceptions: the invitation to contribute to the production of Piers Plowman from the beginning, one that, even if he did not offer it consciously, many of his early readers accepted with relish.

\section{Ashmole 1468, Pseudo-Gluttony, and the quick brown fox}

The final page of the Piers Plowman text in Oxford, Bodleian MS Ashmole I468, a late fifteenth-century copy of the A version, features a contemporary response, or contribution, to the poem's transmission that has barely registered in the Langland archive. The top two lines of Figure 4, "I wt oute penauns ... / Amen Amen," conclude the main text, in its scribe's hand; the next, starting "Gaudete cum gaudentibus" is in the new hand.

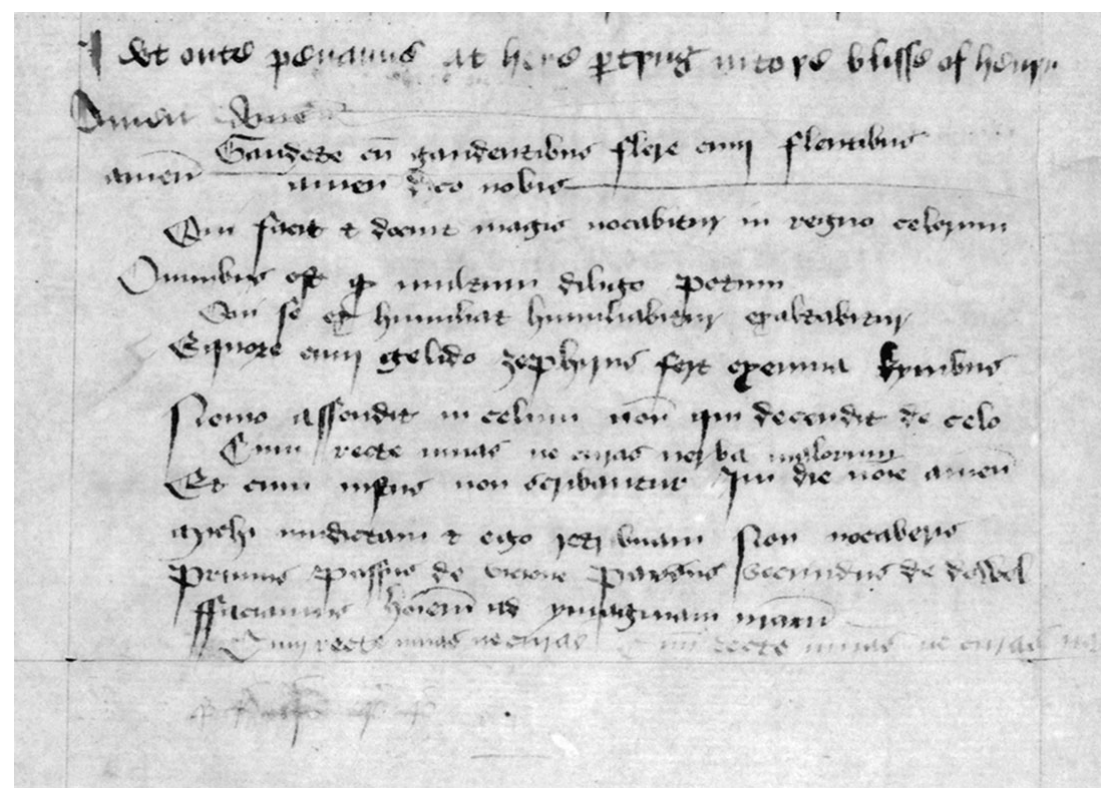

Figure 4 Latin lines following on from the MS's Piers Plowman.

Oxford, Bodleian MS Ashmole I468, p. 378 

Amen — amen dico vobis

Qui facit et docuit magis vocabitur in regno celorum

Omnibus est [notum] quod multum diligo potum

Qui se ex humilitate humiliabitur exaltabitur

Equore cum gelido Zephirus fert exennia kymbus

Nemo assendit in celum non qui decendit de cello

Cum recte vivas ne curas verba malorum

Et cum justus non scribantur In dei [MS die] nomine amen

Michi vindictam \& ego retribuam Non vocaberis

Primus passus de vicione Passus secundus de dowel

ffaciamus hominem ad ymaginam meam

Cum recte vivas ne curas Cum recte vivas ne curas [faded]

Only Walter Skeat has mentioned this item, in his description of the manuscript, but he was not very impressed: "a few Latin quotations are scribbled below, which have occurred in Piers Plowman." ${ }^{\text {"O }}$ His implication that they were written in haste, and unworthy of attention, probably explains the silence that has since greeted the lines. In fact, as this image shows, they are in an attractive Gothic Secretary hand, ${ }^{\text {II }}$ and flow on directly from the main text, as if to be taken as part of it.

The item's contents, too, get short shrift in Skeat's characterization. The "few Latin quotations" in these thirteen lines are in fact fifteen separate quotations copied over seventeen segments, as one, a line from Cato, occurs three times over lines 8 and I3. Two-thirds of the fifteen - six from the New Testament, two from the Old, the Cato item, and a formula - are "quotations, which occur in Piers Plowman," if that phrase refers to Langland's quotations of other items, with the bulk from A IO-II, the final two passus of the poem. ${ }^{\text {I2 }}$ If the phrase means quotations of the poem, the figure increases from ten to twelve such quotations, with the addition of the two rubrics of line II, "Primus passus de vicione Passus secundus de dowel." The remaining three items appear nowhere in the extant texts of Piers Plowman. The first is in keeping with the bulk of this collection: the second part of line Io, "Non vocaberis," which opens Isaiah 62:4, "Thou shalt no more be called Forsaken: and thy land shall no more be called Desolate." The other two, though, could hardly be less appropriate to their context. Line 4, "Omnibus est [notum] quod multum diligo potum," sounds like something Gluttony might have said in another version of passus 5: "Everyone knows I like many a drink." This Leonine quip was common - among its homes is below the conclusion of the Piers Plowman text in San Marino, Huntington Library MS Hm I37, fol. 89 ${ }^{\mathrm{v}}$ - enabling 
easy sourcing of the missing term notum, necessary for sense and internal rhyme. $^{\mathrm{I3}}$ The other non-Langlandian item could not be Gluttony's or anyone else's: "Equore cum gelido Zephirus fert exennia kymbus," the Latin equivalent of "the quick brown fox jumps over the lazy dog," ${ }^{2}$ which, too, appears, among many other places, in another Piers Plowman manuscript, BL MS Harley 604I, fol. $96^{\mathrm{v}}$, in an early sixteenth-century addition beneath the conclusion. ${ }^{\text {IS }}$

These three items prevent any easy characterization of the Ashmolean collection as either a simple continuation of the main text or a digest of its best lines. It is akin to the item on which Jacques Derrida focuses his attention in Archive Fever, the "Monologue with Freud" with which Yosef Hayim Yerushalmi concludes his book Freud's Moses: Judaism Terminable and Interminable. Derrida expends most of his energy on the content of this "monologue," whose implications for the notion of the archive are substantial, but his first observation concerns the very structure of the piece, which is both part of and extraneous to the book proper, a standard history:

In the first place, this fictitious "Monologue" is heterogeneous to the book, in its status, in its project, in its form; it is thus by pure juridical fiction that such a fiction is, in effect, bound in the same book signed by the same author, and that it is classified under eight "scientific" rubrics (nonfictional: neither poetic nor novelistic nor literary) in the bibliographic catalogue whose classical categories are all found at the beginning of the work. ${ }^{16}$

Likewise does the Ashmolean item present itself as an integral part of what precedes but can succeed only as a fiction: hence its near absence from any description of the book within which it is bound.

The final two quotations in the item, the two rubrics that make up line II, nicely embody the dilemmas of the poem's "detachable" Latin and of this collection's relationship with the text of Piers Plowman. On the one hand, of the items on this page only two rubrics must have come from the poem; on the other, they might as well keep company with the "quick brown fox" lines so far as the Langland archive goes, given their absence both from Alford's Guide, for they are not "quotations," and from the main texts of any recent editions, for they are supposedly not Langland's. ${ }^{17}$ Yet some scholars promote the scheme of rubrics as authentic indicators of major structural significance. ${ }^{18}$ Since the case cannot be decided on the grounds of the Latin alone, advocates of the rubrics' authenticity must, somewhat perversely, appeal to their very difficulty as evidence for their case. Thus the transitions marked by their appearance in the final two 
passus of B, says John Burrow, "are so far from obvious that they have even escaped the notice of most modern scholars"; they mark "the deep structure of his poem." ${ }^{\text {I9 }}$

Yet Langland's readers did recognize, and mark, such deep structural elements of the poem, and did so even long after its original composition. The table of contents of CUL MS Gg.4.3I (c.1544) divides Piers Plowman into thirty-five chapters, signaled in the main text by the use of capitals. ${ }^{20}$ "Not surprisingly," observes Judith Jefferson, these chapter divisions "suggest structural interest. Chapter breaks occur at significant points of transition." These can be changes of subject matter, or of modes of literary discourse, or of plot development: the chapter break at B I.79, for instance, is the point at which the Dreamer's "vision suddenly becomes personal (he falls on his knees and asks Holy Church how he may save his soul), while that at 6.253 occurs at a similar juncture, at the point where the criticism of those who are wasters suddenly becomes personal to Piers." To grant the possibility that the rubrics might not be authorial, then, one need only imagine the actions of a single reader of equivalent interest and acumen to those manifested in CUL Gg.4.3I, at work on the poem much closer to the moment of its origins.

In remarking that the rubrics mark deep structural transitions inaccessible to all but the poet, Burrow voices a common belief about the role of the Latin tags as well. While they might appear to be afterthoughts intended to provide an authoritative gloss to the English, these quotations are in fact, so John Alford argues, "the matrix out of which the poetry developed," and the question of their relation to the rest of the poem is "more pertinent than any other to the art of Piers Plowman." 22 This argument presents Langland as "eking out his poem slowly, even tediously, while poring over a variety of commentaries and preacher's aids - and this picture is entirely consistent with the practice of countless of his contemporaries, with the structure of the poem itself, and with the fact that he was a tireless reviser." ${ }^{23}$ Following Alford's lead in this respect, the analysis of Langland's Latin over the past decade or so has emphasized its distinctive status over its general milieu: "while Latin quotations in English manuscripts often take the form of marginalia designed to gloss and bolster the authority of what the English text already says," Fiona Somerset remarks, "Langland's usage is by now understood to be far more complex and varied, and in many cases an integral part of his poem's project."

Prime among Somerset's examples is the set piece of the angel's proclamation in the Prologue, "Sum Rex, sum princeps; neutrum fortasse deinceps" etc. (B Prol.I32f.), which Traugott Lawler has now even posited as an authentic 
Langlandian composition. ${ }^{25}$ A substantial number of tags are incorporated syntactically into the English, or are necessary referents of the English, such as "The sauter sayth in pe psalme of Beati omnes: / Labores manuum

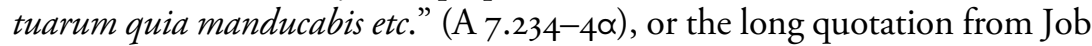
and a commentary on it followed by "Yf lewede men knewe this latyn a litel" (C 17.53-4). But complex and varied usage on the whole does not necessitate complexity in every instance, or even in very many of them. However much the extraordinary Latin of Piers Plowman captures the imagination, the fact remains that most of it consists of straightforward quotations that many readers knew very well, and that could be, as it were, re-detached: hence the Ashmolean collection of thirteen tags. This was a simple model that readers could also adopt as their own: hence the Ashmolean addition of three new items to that collection.

The item at the end of Piers Plowman in that manuscript presents one final, even more basic, dilemma: how it is to be incorporated into definitions of the poem. The issue, in sum, is the one on which Derrida focuses with regard to the Freud archive: whether this is a witness to the poem itself, or to the reception of that entity. The first option is not so easily dismissed, for one of the rubrics it cites, and both items of line 9, "Et cum justus non scribantur" and "In [dei] nomine amen," are absent from the main text of this copy, the pages that attested them having gone missing. Strictly speaking, these lines together constitute an independent witness to Piers Plowman of equal authority to the lines of the main text. It is also possible, if unlikely, that this inscriber was copying from the exemplar behind the Ashmole copy, which would render all the lines from the poem that appear here of equal textual authority to the main poem. Yet this item has never been collated in, cited in, or even explicitly rejected from any edition. It appears in no lists of witnesses, in which, even if they are arbitrarily confined to items of potential textual authority, that is, whose text cannot be dismissed as derivative of another extant witness, the Ashmolean collection would seem to merit inclusion. Since other excerpts, both shorter and later than this one, often show up on lists of the extant manuscripts, as we saw in the Introduction, it must be either the item's Latinity or its proximity to a main text, neither of which has any real bearing on the issue, that has prevented its inclusion.

It is interesting to ponder how criticism would have dealt with these Ashmolean lines had they been in English. Perhaps they would still have been ignored, for being derivative of the main text, or, to be more optimistic, celebrated for being so much more than the collection of nota benes with which readers usually have to be content as markers of 
reception. Once one does notice them, I have argued, these lines raise some fundamental questions, by themselves accommodating three modes of Latin: the sort seemingly integral to the poem (Cato, St. Paul, etc.); that most likely added by an early reader but generally accepted to be part of the poem (Primus passus de vicione, etc.); and that in turn added by the latest generation of audience, who saw no reason that Pseudo-Gluttony and the quick brown fox could not take their place within the disparate collection of materials known as "the Latin of Piers Plowman." What Derrida says of Yerushalmi's "Monologue" applies to the list of Latin lines in Ashmole I468 as well: "this postscript of sorts retrospectively determines what precedes it." ${ }^{26}$ It turns Piers Plowman itself into something much different from anything we have known before.

\section{The fullness of time: from the margins into the text}

If the Ashmolean inscriber added new items to his collection of Piers Plowman's Latin, others added them to the poem itself. In doing so Langland's readers were following his own example, for they knew the same reservoir of biblical, legal, and aphoristic materials as he did, and could even supply it when the poet himself was content to rely on English versions. One such instance concerns the Donation of Constantine, the apocryphal act that was believed to have ceded the Lateran in Rome to the papacy. This is anathema to Langland (or, at least, to the narrator, Anima in received B, Liberum Arbitrium in C), who tells the famous legend that a sign came from above indicating the travesty of this transference of authority:

Whan Constantyn of cortesye holy kirke dowede

With londes and ledes, lordschipes and rentes,

An angel men herde an hye at Rome crye,

"Dos ecclesie this day hath ydronke venym

And tho pat haen Petres power aren apoysened alle."

(B I5.557-6I/C I7.220-4)

In the $\mathrm{B}$ tradition's $\mathrm{OC}^{2}$ manuscript group, the lines appear as above, but with the addition, after line 559/222, of hodie venenum est effusum in ecclesiam domini, "today venom is poured forth in the church of the Lord." This phrase had been what the angel said since at least the thirteenth century; in Langland's era it "is cited in Higden's Polychronicon IV 26 and Gower's Confessio Amantis Book 2, and was favoured by Wycliffe (e.g. Dialogue IV, I8)," as A. V. C. Schmidt observes in his commentary on this passage, citing, of course, the $\mathrm{OC}^{2}$ item as further evidence. ${ }^{27}$ 
Langland clearly had this line in mind as well. The received quotation is a very good translation, both literal (hodie, "this day"; venenum, "venym") and filled out in ways characteristic of Langland's translation practices. Line 560/223 exemplifies his "urge to make clauses with verbs" where the Latin is compressed (here, by the passive construction of est effusum), and 56I/224 manifests his "urge to expand and to specify," since this is only implied in the Latin. ${ }^{28}$ The only slightly uncharacteristic feature in $\mathrm{OC}^{2}$ is that the Latin appears before the translation, rather than after as is usually the case; but as we will see in a moment there are material reasons for that location. The same thing occurs later in the poem as well, at B I6.93-5, about the fullness of time when Jesus will take on his ministry, ${ }^{29}$ presented here in the text of $\mathrm{C}^{2}$, CUL MS Ll.4.I4:

Till plenitudo temporis: ffulli come were

Pat peers ffruyt fflouride \& ffelle to be ripe:

Annis quingentis decies rursumque ducentis

Unus defuerat cum deus ortus erat.

And pan shall Jesus juste perfore bi jugement of armes. (fol. $80^{v}$ )

This belief that Christ would be born exactly 5,199 years after the Creation frequently initiated brief chronologies of the world that were produced through many centuries and in many regions. ${ }^{30}$ The addition, while less intimately related to the passage than the other $\mathrm{OC}^{2}$ addition is to the Donation of Constantine, still fits its new context perfectly; likewise the lines' Leonine hexametrical form, which Langland favored as well. Had either of these $\mathrm{OC}^{2}$ additions been inscribed into the margins of the exemplar behind the $\mathrm{B}$ archetype and taken up into the main text of that copy, no one would have doubted its integrity.

These two instances demonstrate that the Latin additions to the manuscripts were not necessarily the insertions of scribes as they wrote out their copies. Rather, these additions moved into the main text, where they appear in $\mathrm{C}^{2}$, from the margins, their home in $\mathrm{O}$ (Oxford, Oriel College MS 79). While MS O often places its Latin in the left or right margin, the angel's cry is the only such tag inscribed above its folio's top ruling (fol. $67^{\mathrm{v}}$ ), while the lines on the fullness of time are the only ones just below their folio's final ruling and above its bottom edge (fol. $\left.69^{\mathrm{r}}\right) .{ }^{3 \mathrm{I}}$ These tags must thus have been in the equivalent margins of the group's mutual common ancestor, whose mise en page the $\mathrm{O}$ scribe reproduced faithfully while his $\mathrm{C}^{2}$ peer decided instead to normalize his text. ${ }^{32}$ Some manuscripts of both Gower's Confessio Amantis and Chaucer's Canterbury Tales likewise bring Latin marginalia into the main text. ${ }^{33}$ In those cases, where 
the Latin goes on for many lines and, in the case of Gower, serves as commentary on the English text, the practice was very disruptive. But Langland, always much more economical in his own treatment of Latinate glossing, enabled those who followed his example to go unnoticed.

If the reader of the $\mathrm{OC}^{2}$ exemplar could provide the Latin that lay behind the Poison of Possession lines, so could a reader of any of the three archetypal manuscripts. This means that in theory any detachable Latin in received $\mathrm{A}, \mathrm{B}$, or $\mathrm{C}$ could have originated as a reader's gloss. Take, for instance, Haukyn's rationalization of his sin-stained coat at the beginning of B passus I4, which Alford calls "Langland's most sustained, and perhaps most successful, use of the method" of concordance. ${ }^{34}$ The proof that this could be non-authorial is simple: we need only remove the Latin to see if the passage works without it.

"Y have but oen hole hatur," quod Haukyn, "y am the lasse to blame Thogh hit be soiled and selde clene y slepe perynne on nyhtes; And also y have an hosewyf hewes and childrene

Pat wollen bymolen it many tymes maugre my chekes!” (B I4.I-4)

Haukyn's appeal to his possession of a wife could easily have prompted a reader of a manuscript to add to the holograph's margins a New Testament line, Uxorem duxi \& ideo non possum venire (Luke I4:20). The scribe who took this copy as his exemplar, like the $\mathrm{C}^{2}$ scribe, would then have incorporated the Latin into his text after line 3, ensuring its appearance in all the B copies. An even more sophisticated reader might have recognized that the parable from which this line comes "provides the theme for Passus I4," as Alford points out ${ }^{35}$ - all the more reason, then, to add the pertinent lines from the gospel reading itself, as well as those from the commentaries built up around it. Such speculation is not to deny the force of Alford's approach, or of any argument that takes detachable lines to be integral to the poem. On the contrary, it is to acknowledge that Langland wrote for an audience conversant with this procedure, who thus could fill in the very Latin lines that inspired the poet in the first place, which is just what occurred in the $\mathrm{OC}^{2}$ group.

\section{Unidentified scraps}

The Latin of the received versions most likely to have originated as marginal glosses is not of the character found in Haukyn's lines, even if we cannot rule out that possibility. It is, rather, the sort that features what Helen Barr calls the most characteristic appearance of the quotations: 
"their standing apart from the actual verse form such that they could be written at the side of the English as marginal glosses." ${ }^{36}$ Since most of the criticism of Piers Plowman's Latin focuses on the extraordinary, it will be worth spending a few moments to get a sense of this material's character and provenance. The fullest treatment is John Alford's Guide to the Quotations, but there remain what he calls "unidentified scraps," 37 whose elusiveness might seem to suggest origins in milieux different from the grammatical, legal, and theological ones Alford identifies as most important. It has thus even been suggested that Langland himself composed some of this material. Yet the quotations for which I will now offer new or corrected identifications, like so much of the rest of Piers Plowman's Latin, were part of a common storehouse of aphorisms emanating from these and closely related modes of discourse. The fascination with the poet's unique and innovative qualities has obscured the presence at those very locations of the opposite qualities, the ones in which the poem could belong to, or include contributions by, any educated reader.

First is a line from one of the most delightful passages unique to the A version, quoted at the beginning of Chapter 2, Wit's invective against those restless and reckless souls who futilely wander about among the religious orders:

Y have lerned how lewid men han lered here children

Pat selde mosseth pe marbil pat men ofte treden,

And riht so be romeris bat rennen aboute

Fro religioun to religioun, recheles ben pei evere;

$\mathrm{Ne}$ men pat conne manye craftes, clergie it tellep,

Thrift oper thedom with tho is selde yseyen:

Qui circuit omne genus in nullo genere est. (A ro.103-8 $\alpha$ )

Skeat, querying the origin of this tag, said "this is used to express that a man who is Jack of all trades is master of none." ${ }^{38}$ His query would not be answered until Teresa Tavormina finally pointed to Higden's very close remark, "Immo nonnulli omne genus circueuntes in nullo genere sunt, omnem ordinem attemptantes nullius ordinis sunt," as the closest analogue, leading to at least one claim that Higden informed some central aspects of English identity, in this case those of "recklessness" and elusive identity. ${ }^{39}$

In fact there is a direct source for both Piers Plowman and Higden: a reportatio of Peter of Auvergne's Questions on Aristotle's de Caelo (c.1277-89), in the discussion of "whether the first mover moves the primum mobile, i.e., whether the first orb is moved immediately by the first mover or whether it has a proper mover besides the first mover." ${ }^{40}$ Following the 
typical structure of the scholastic question, Peter first presents arguments in favor of the position with which he will disagree. One of the two arguments to be rejected is home to our item:

Item principium universale non appropriatur alcui enti, quia quod circuit omne genus in nullo genere est; sed primum principium est causa universalis, efficiens principium omnium. ${ }^{41}$

The universal principle is not particularly related to a particular being, because whatever encompasses every origin is in no origin; but the first principle is the universal cause, the efficient principle of everything.

Peter responds by saying that this argument does no more than state the obvious truth that each orb has its own efficient cause, its own proper mover. But, he objects, "the first mover is particularly related to the primum mobile. It moves the first orb in ratione amati et desiderati with the daily motion from east to west. Consequently, it moves all inferior orbs, and in this sense it is an efficient cause as well." ${ }^{42}$ Whoever was responsible for the tag in Wit's lines, whether Langland or an early reader, must have had an innate interest in such material, given that this section of Piers Plowman relies so heavily on scholastic theology. If Langland was familiar with Peter of Auvergne's Questions, he would have known that Wit's tag ends up on the losing side of the debate. Dame Study's wrathful reaction to her husband's speech (A II.If.) would no longer appear to be the first indication of its dubious nature. But the tag's presence in the A version itself, as well as its obvious influence on Higden, shows that it thrived quite apart from its original context.

Michael Calabrese judges "Sunt infelices quia matres sunt meretrices," "They are accursed, for their mothers are whores" (C 3.1900), in Conscience's invective against priests' keeping of mistresses, to be "one of the most striking additions to $\mathrm{C}$ of any kind": hardly a scrap. ${ }^{43}$ Also apt is Calabrese's observation that "the line could very well be a scribal gloss inserted into the text as if it were a line of poetry, or it could have been a line of text that became a scribal gloss, as in [MS] F." ${ }^{4}$ This Leonine tag has resisted identification because it is separated, so far as I am aware only in Piers Plowman, from the companion with which it elsewhere appears: "Presbiteri nati non possunt esse beati, / Sunt infelices quia matres sunt meretrices." ${ }^{45}$ Another English collection of proverbs, in Oxford, Bodleian MS Rawlinson D 328, cites the first of these lines alone, together with translation: "Presbiteri nati non possunt esse beati. / A preste-ys chyld schall never be blessyd." "The marginal annotation of C 3.189 in Huntington MS Hm I43, "notate prestes gurles" (fol. $13^{\mathrm{r}}$ ), ${ }^{47}$ is closer 
linguistically to the maxim's presbiteri nati than to the poem's more belabored reference to Meed's maintenance of "prestes ... to hold lemmanes ... And bringeth forth barnes azenes forbodene lawes" (C 3.I88-90). It might well be that, as Calabrese suggests, an earlier annotator had decided that Langland should have inserted this well-known misogynist maxim instead of going on and on with this wordy allegory.

Later in C, Imagynatif expounds the gifts of grace and kind wit, saying in Latin that "the phenomena of this world are subject to the configurations of the heavens":

So grace withouten grace of god and also gode werkes

May nat be, be pow syker, thogh we bidde evere.

Ac clergie cometh bote of syhte and kynde wit of sterres,

As to be bore or bygete in such a constillacioun;

That wit wexeth therof and oper wyrdes bothe:

Vultus huius seculi sunt subjecti vultibus celestibus.

So grace is a gifte of god and kynde wit a chaunce

And clergie a connynge of kynde wittes techyng. (C I4.28-34)

This tag, too, eluded the efforts of Skeat, Alford, Pearsall, and Schmidt, the last of whom, calling it "a quotation (if such it is) of untraced origin," suggests that it might be Langland's own. ${ }^{48}$ In fact, in 2002 Stella Pates, having recognized it in the copy of Pseudo-Ptolemy's Centiloquium included as part of Oxford, Bodleian MS Bodley 463, became the first modern reader of Piers Plowman to identify the quotation. ${ }^{49}$ What she does not say is that the Centiloquium was a sort of Disticha Catonis for anyone interested in cosmology. Arabic sources of the twelfth century provide the earliest evidence for its existence, and over a hundred and fifty Latin manuscripts are extant. This was among its more popular aphorisms, making its way into such texts as Dante's De Situ et Forma Aque et Terre and Constantine of Pisa's Liber Secretorum Alchemie. ${ }^{\text {so }}$

Finally, and most famously, Pacientes vincunt: if Langland's poem has a motto, this, "the patient conquer," is it. This tag appears more often than any other Latin clause, six times over three passus in the B version (I3.135a; I3.I7I $\alpha$ I $4.33 \alpha$; 14.54 [= C 15.253]; I5.268; I5.598 $\alpha$; also C I5.I37, I5.156), and its lesson is in operation even where not cited: as Stephen Barney observes, Langland's Jesus conquers the devil by hiding and suffering in $\mathrm{B}$ passus I $8 .^{\mathrm{II}}$ By no one's standard could this be considered scrappy: yet it is exactly like the items identified above in resisting the pall of uniqueness with which modern critics have imbued it. "Scrappiness" is an index not of these Latin lines' character but of our knowledge. While "patientia vincit omnia" is proverbial in the singular, Alford says that Langland "offers the 
only example in the plural," a statement that still holds. ${ }^{52}$ Yet the Latin plural appears as well in a source that Alford has already identified as a likely major source for Langland's quotations about the rich and poor in passus I4, among the homes of pacientes vincunt itself. This is John Bromyard's Summa Praedicantium, under the heading "humilitas":

Opus quod nobis incumbit est bellare contra diabolum: quia vero superbus est contra eum non pugnat, sed vero sub eo militat, nunquam eum vincit. Qui vero humilitate et pacientia contra eum pugnant, vincunt. Sic ergo dum pacientes vincunt, "de sua virtute gloriantes humilias." 53

The work incumbent on us is to war against the devil: because in truth he who is proud does not fight him, but serves as a soldier under him, and never defeats him. In truth those who fight him with patience and humility conquer. Thus, while the patient conquer, "thou humblest them that glory in their own strength" (Judith 6:15).

Alford deems it very likely that "the poet drew upon the [biblical] commentaries and upon some such work as Bromyard's (if not the Summa Praedicantium itself) for the majority of his quotations." 54 Pacientes vincunt cements the case.

The tags and lines we have been discussing originate from wildly disparate milieux, ranging from Parisian scholastic lectures of the I27Os to the witty misogyny that soils flyleaves and proverb collections. Many of them could have come into Piers Plowman via grammatical texts, a notion that has recently been promoted as the driving force of Langland's Latinity; ${ }^{55}$ but each argument in favor of that milieu equally supports the artes praedicandi in which we find Bromyard as primary conduit: grammar texts and sermons share a substantial proportion of their respective characteristics, and preachers, after all, had once been schoolboys. Christopher Cannon adduces Langland's "habit of repeating quotations, often with very long stretches of the poem intervening between one citation and the next" as evidence for the Latin's schoolroom origins, but this characteristic led A. C. Spearing to note Langland's indebtedness to the methods of digressio and descriptio emphasized in medieval English artes praedicandi. ${ }^{56}$ Medieval English sermons feature Latin-English lines that are alliterative, punning, and witty, such as "non vultu ficto and ficle verbis sed pleno corde" and "diu laboravit graviter in gravynge istorum signorum." 57 While Cannon seems to imply that hexameter Leonines are strictly the provenance of grammar texts, in fact they pervade sermons as well. ${ }^{58}$ Likewise, "the use of proverb collections as reference books for preachers is well documented." 59 And this Latin was sophisticated in ways that would have attracted Langland and his readers: "often a biblical figura invoked in the 
sermon text does not merely look back at the doctrinal matter to be proven but at the same time points forward and provides the ground for further amplification," remarks Siegfried Wenzel, who concludes: "To find an appropriate biblical figura ... and weave it meaningfully into the verbal texture of the sermon surely requires skill and intelligence."

Yet replacing the schoolroom with the pulpit as immediate origin of Piers Plowman's tags merely replicates the problem. This material was universal. The aphoristic, moralistic sorts of Latin tags found throughout Piers Plowman provided both the themes and content of sermons, of grammatical instruction, and of poetic composition, so there is little point attempting to determine their precise milieux. Scraps or not, these items have substantial implications for the fabrication of the Langland archive, calling into question the possibility of attributing some of the most important lines of its foundational entity, Piers Plowman, to its namesake.

\section{Excerpting Piers Plowman, c.1450-1600}

The converse of the phenomena discussed over the previous few pages is epitomized in Ashmole I468: the excerption of Piers Plowman in ways that emphasize its Latinity. The opening English lines ("In a somur sesoun ... ”) show up at the end of the C-version text in Huntington MS Hm I43 and in National Archives EIor $/ 516 / 9,{ }^{61}$ and a few prophetic passages make their way into compilations in the sixteenth century, as Chapter 4 will show. Yet it is striking to realize that all other known instances of excerption present the poem's Latin either on its own or wholly subordinate its English to the Latin. This applies even to the single other instance of a standalone English excerpt from Piers Plowman, which occurs in a quire of flyleaves added to the beginning of Bodleian MS Bodley 85I by one "Dodsthorp," the final compiler of the manuscript. "Chastite wihtout charite brennit in helle" appears here (fol. $3^{\mathrm{r}}$ ), and, while definitely from Piers Plowman, is almost certainly not from the $\mathrm{Z}$ version found later in the volume, originating as either A I.I62 or C I.I84. ${ }^{62}$ Yet this is but one of "over seventy items, a few English or French but most Latin" in these flyleaves' pages, says A. G. Rigg: "the mixture is typical of fly-leaf poetry of the period: there are items of local interest, riddles, proverbs, literary extracts, drinking and begging poems, etc." ${ }^{33}$ The full-scale Piers Plowman in this manuscript was already bedfellows with Walter Map, John of Bridlington, and other Latin materials by the time it reached Dodsthorp, who in turn inscribed its English fully into that Latinate world, perhaps not even realizing it was from Piers Plowman at all. 
The longest relatively brief excerpt of Piers Plowman, too, accentuates the Latinate. "Nota bene de libero arbitrio secundum Augustinium \& Yisidorum": thus writes John Cok on the final blank folio (p. 210) of Cambridge, Gonville and Caius MS 669*/646, proceeding to inscribe Piers Plowman C 16.182-20Ia. "We might pass over as insignificant this scrap" - that word again - "of twenty lines on Free Will which he appends to his anthology," were it not for the information it provides, writes George Russell: "We know that Cok was a cleric attached to St Bartholomew's Hospital in the first half of the fifteenth century, and this fragment tells us that he had access to a Piers Plowman manuscript and remembered, or wished to register, the present passage." ${ }^{64}$ Textual affiliations even indicate that he consulted CUL MS Ff.5.35. ${ }^{65}$ But even though Cok was busy writing the Englished Richard Rolle into this volume, he showed comparatively little interest in the vernacular of Piers Plowman. In the sixteen English lines he writes, Liberum Arbitrium offers the Latin names for English concepts associated with himself: Anima, Animus, Memoria, sensus, Amor. Cok departs from Ff.5.35 in replacing the final three English lines, 199-20I, with a single one translating I99, "Secundum augustinum \& ysidorem \& quemlibet eorum," followed by the culminating self-definition, $201 \alpha$, which occupies some five lines in Russell and Kane.

One could hardly do more to turn a triumph of vernacular poetry into a repository of scholastic Latinity. Yet Cok did just that: for though it has gone all but unnoticed, his first inscription of the poem into his volume occurs much earlier in the book, in the bottom margin of p. 87, when he provides, as a gloss on the discussion of poverty in the Englishing of Rolle called "Amore Langueo" there copied, the definition of poverty that we now call Piers Plowman C i6.116:

paupertas est odibile bonum, remocio curarum, possessio sine calumpnia, donum dei, sanitatis mater, absque solicitudine semita, sapiencie temperatrix, negocium sine dampno, incerta fortuna, absque sollicitudine felicitas \&c. ${ }^{66}$

Cok's omission of the phrase "quod pacience" after paupertas, which occurs in all other witnesses to the passage, underscores the extent to which he subordinated the English of Langland's poem to its Latin. Had he not included the following excerpt from the same passus a few pages on, no one would have suspected this is from Piers Plowman at all.

Cok was joined by early seventeenth-century readers like Richard James and Gerard Langbaine in writing out entire passages from Piers Plowman 
that are included in recent lists of its manuscripts. ${ }^{67}$ At least one peer of these figures might have received equivalent attention were it not for his work's character (Latinate, a collection of single lines) and location (on the blank page facing the first page of text in a $\mathrm{Cr}^{2}$ now at Yale). This italic hand inscribes some twenty-four items together with the folio or folios on which they appear, beginning: "Heu mihi quod sterilem duxi vitam juvenilem 6b. 27b." ${ }^{68}$ This reader knew such material well enough to substitute quod for the Crowley text's quia in that first quotation (I.I4Ia and 5.4400), to enumerate the definitions of Anima that so interested his predecessor John Cok ( $15.39 \alpha)$, and to attribute $15.343 \alpha$, "De sacerdotio ex Chrystostom: Sacrilegium 82b," rather than quote the original Quia sacrilegium est res pauperum.

This annotator exhibits no interest in Piers Plowman as either a prophecy of the Reformation or a defense of the old ways, as either a populist site in which Latin texts are distributed to an English readership or a proponent of radical Latin. It was instead, as a glance at Figure 5 reveals, more or less the same as it was for the Ashmolean commentator, the $\mathrm{OC}^{2}$ contributor, John Cok, and many others whose approach has not had much of an impact on studies of the poem's production and reception. This was a work in which the poet's individual vision was subordinate to a communal conversation, one most eloquently expressed in Latin. The extent to which this reader saw Piers Plowman as Visio Willielmi de Langlond is apparent from his addition of a small number of Latin marginal and interlinear notes in the main text, such as Insomnium Pierii beside "I slombred into a sleping, it swyzed so mery" (sig. A. $\mathrm{i}^{\mathrm{r}}$ ); and the interlinear gloss possent for "they moote" (sig. L.iii").

With the possible exception of Cok's excerpt of the line on poverty, all of the passages considered in this section could only have come from Piers Plowman. In concluding this brief history of excerpting Piers Plowman, though, we come up against the problem that bedeviled the earlier discussion of the communal character of so much of the poem's Latin. For pacientes vincunt appears elsewhere than in John Bromyard and Langland's poem: it is among the Latin glosses in the Canterbury Tales now in BL MS Egerton 2864 (c.1450-75), fol. $155^{\mathrm{v}}$, next to the Franklin's explanation of why patience is so high a virtue: "For it venquissheth alle thes clerkes seyn" (774). Joanne Rice's notes in The Riverside Chaucer mention the Latin phrase's appearance in Piers Plowman, but since her focus is on Chaucer's own poetry she does not go so far as to cite it as the annotator's source. ${ }^{69}$ Yet it is clear that he got it from somewhere: he uses the margins to inscribe the authorities behind Chaucer's poetry, not to innovate 


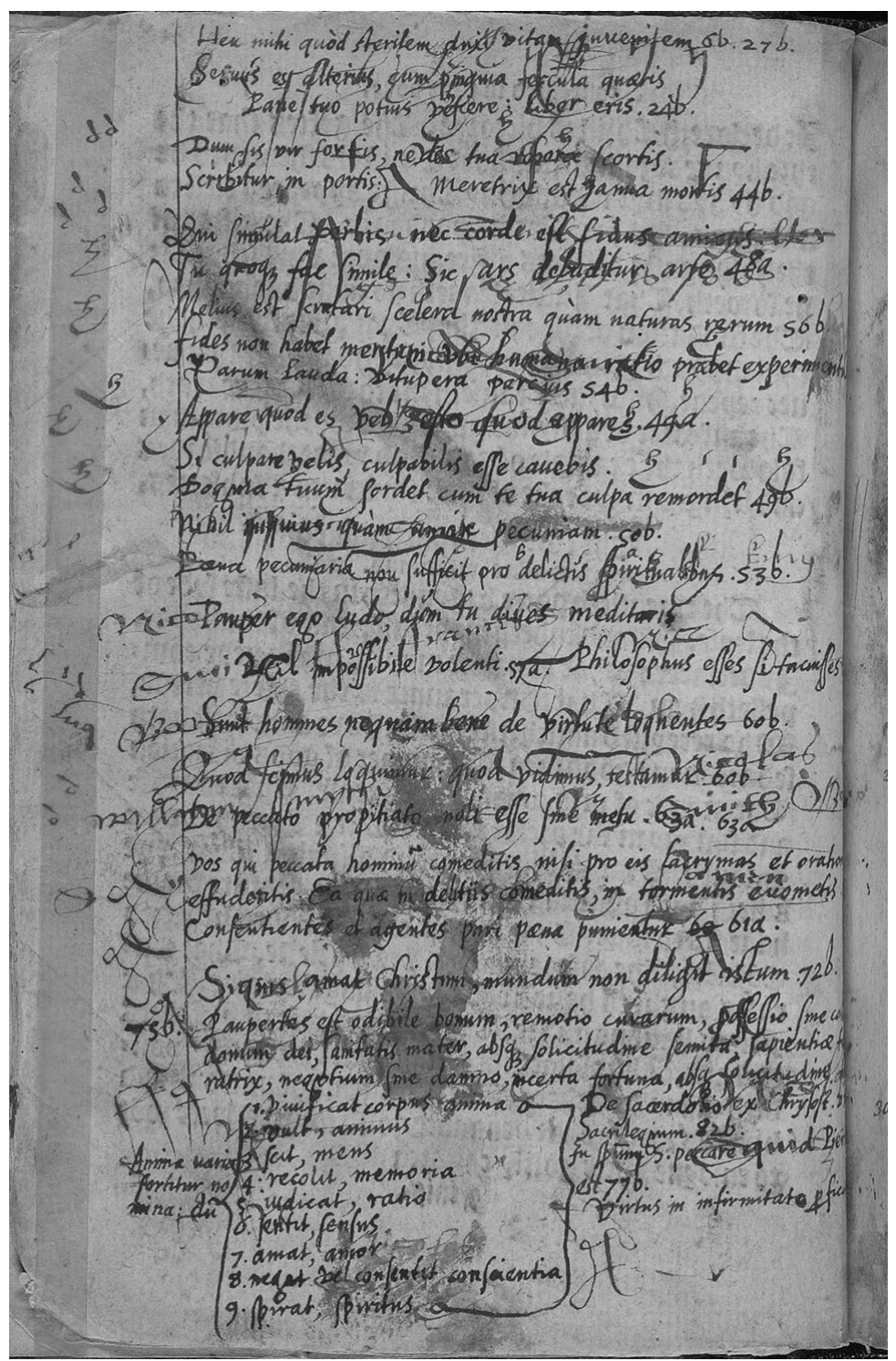

Figure 5 Latin lines from Piers Plowman transcribed in a Crowley. New Haven, Beinecke Rare Book and Manuscript Library, Yale University, ID L 26 550c, sig. $4^{\mathrm{v}}$ 
or comment. While Bromyard or another lost or unknown source is a possibility, Langland is easily the best candidate, though no one has ever said as much. Should this be added to any complete list of witnesses to Piers Plowman? On the one hand, of course; on the other, of course not.

That is to say, while its source is almost certainly Piers Plowman its inclusion in any such list would need to come with an asterisk, since the phrase is not original to Langland. But that is already the case for any number of items whose inclusion makes one wonder about the exclusion of, say, the Ashmole and Beinecke lists of Latin lines. There are two problems, then: the local one of the prominence of proverbial and biblical Latin throughout his poem, and the broader one of the very definition of "Piers Plowman" and what counts as a witness. If the question of the quotations' relationship to the rest of the poem, to its definition and identity, is more pertinent than any other to the art of Piers Plowman, the assumption that Langland was necessarily responsible for all the detachable Latin needs to be abandoned: the Langland archive, given the centrality of Latin to its constitution, should, strictly speaking, be the Langland-and-others archive. Still more pressing is the need for an acknowledgment of the reality that the poem was for much of its audience primarily a repository of Latinate learning, whether scholastic and learned or aphoristic and populist, even its English aphoristic lines occurring in such a context. The classroom, the parish priest's desk, the cleric in the local hospital, the later fifteenth-century annotator of the Franklin's Tale: these, more than the lollers or rebels like John But or celebrity scribes like Adam Pinkhurst and John Marchaunt, are at the heart of the generation of the Langland archive, their beloved poem not so much a brilliant poet's English vision as a space not found elsewhere in the canon of major medieval English poetry, in which unidentified scraps share the glory with Conscience's quest for Piers the Plowman. 


\section{"Quod piers plowman": non-reformist prophecy, C.IS20-IS55}

If most Piers Plowman excerpts strike a communal chord on account of their aphoristic, even scholastic, character, others' populism comes from a different place altogether. Especially in the sixteenth century, an anti-intellectual, oral, prophetic, and, crucially, non-reformist mode, so I will argue, was the predominant approach to Langland's poem, perhaps even in ignorance that what we would today call "excerpts" originated there at all. Six independent productions of $c .1520-55$ juxtapose B passus 6's "hunger prophecy" about Davy the Dyker with either of two passages, in B Io and I9, that tell of a king who will correct "the abbot of Abingdon" and subjugate the religious. These standalone prophecies, like the detachable Latin of the manuscripts, have an uncomfortable relationship with the received Langland archive of this era, as constituted and interpreted so influentially by Anne Hudson: "Most of the references, real or apparent, in the two centuries after the composition of Langland's poem associate it with reforming views - most often with views that at the time of composition would have appeared radical or heterodox."

The foundation for this approach is solid: Robert Crowley's three I55O editions of The Vision of Pierce Plowman, which characterize the era of the poet, whom he calls "Robert" Langland, as one when "it pleased God to open the eyes of many to se hys truth, geving them boldenes of herte, to open their mouthes and crye oute agaynste the workes of darckenes, as dyd John Wicklyfe" (sig. *ii ${ }^{\text {). }}{ }^{2}$ Crowley thus transforms the poem "into a prophecy of the advent of the Protestant millennium of the sixteenth century," much as the rest of his era did, in the received account. ${ }^{3}$ Yet this account is backwards, as a more capacious, and more representative, archive of the sixteenth-century Piers Plowman shows. The Langland archive, so this chapter argues, has mistaken as the mainstream a mode that in fact constituted a rearguard attack on the predominant approach, which was decidedly non-reformist and oral.

\section{Piers Plowman in Winchester: two monks' heads and political prophecy}

The context of the item that brings our body of evidence into focus undoes any sense that the sixteenth-century Langland archive is inherently 
Protestant. The volume in question, BL Additional MS 60577, goes by a title that itself brings Catholicism back into the picture: "The Winchester Anthology." "In the first half of the I6th century," as John E. Paul observes, "few counties were more fundamentally Catholic in culture than Hampshire," especially Winchester. ${ }^{4}$ These sympathies are amply manifested throughout the Winchester Anthology, which was produced over a century or so in the Benedictine priory of St. Swithun's or its successor after the dissolution of the monasteries, Winchester Cathedral. Most of the Anthology's contents, entered in the fifteenth century, are conventional enough - an Englishing of Book I of Petrarch's Secretum, lyrics, sermons, The ABC of Aristotle - but its later owners and their additions imbue the volume with a full-blooded Catholicism. Thomas Dackomb, who owned this volume from c.I549, had a book collection showing that "he remained loyal to the old religion," remarks Andrew G. Watson; ${ }^{6}$ the next owner to have inscribed his name, William Way, a lay singing-man in the cathedral, added both a letter by the English Jesuit Ellis Heywood (fol. Io8 ${ }^{\mathrm{r}}$ ) and the sermon given by Bishop John White of Winchester at the funeral of Queen Mary (fols. $19 \mathrm{I}^{\mathrm{r}}-204^{\mathrm{r}}$ ).

Among the volume's later items is an excerpt from Piers Plowman that has never figured in accounts of the poem's witnesses or histories of its reception. ${ }^{7}$ This is the only contribution by this hand, which is otherwise unattested in the collection (see Figure 6). ${ }^{8}$

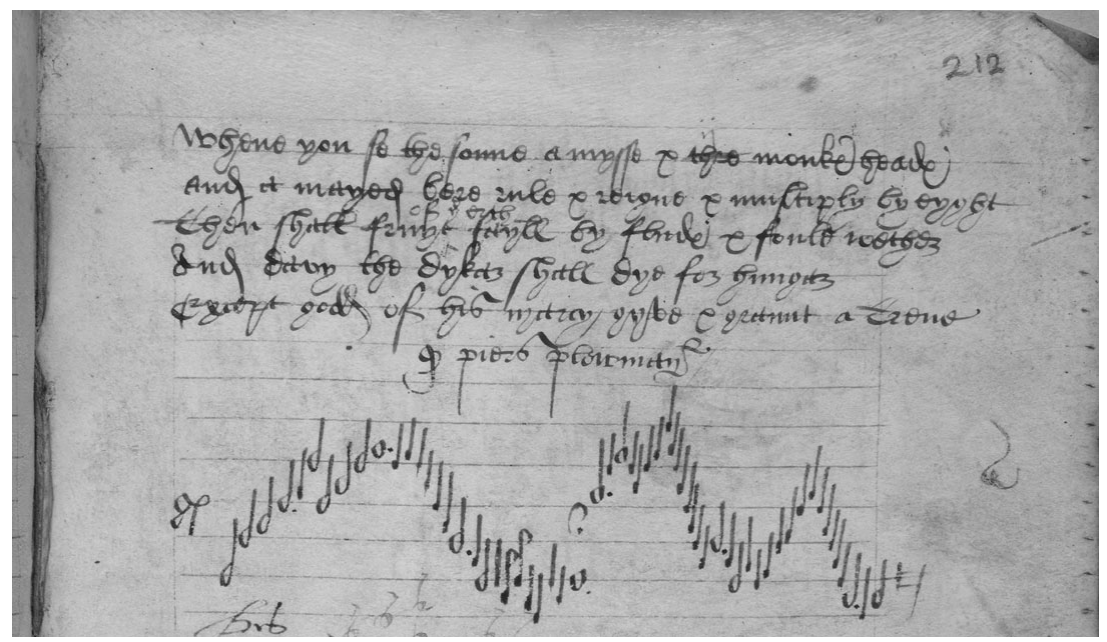

Figure 6 "Two monks' heads" prophecy in The Winchester Anthology. London, British Library, Additional MS 60577, fol. 212 ${ }^{\mathrm{r}}$

Whene you se the sonne a mysse $\&$ thre $<$ ii $>$ monkes heades And a mayed bere rule $\&$ reigne $\&$ multiply by eyght 
Then shall fruyt $\wedge$ of pe erth $\wedge$ fayll by fludes $\&$ foule wether And davy the dykar shall dye for hungar

Except god of his marcy gyve \& graunt a Treue

Quod piers plowman

The text is Piers Plowman B 6.327-8, 325 (after 329's Then), 330-I, which I will call the "monks' heads" or "hunger prophecy," but it is the concluding tag, "Quod piers plowman," that gets to the heart of this item's character. In the received poem the lines belong to the narrator; but here they constitute a free-floating text, which Derek Pearsall, in the sum total of commentary to date, describes as "a copy made from memory." Memorize is what one does with prophecies, after all, ${ }^{\mathrm{IO}}$ and from its earliest appearance this passage attracted the sort of attention that would easily lead to its extraction from its written context into a standalone existence. Eight manuscripts of Piers Plowman feature some sort of marginal notation, for instance. "II "Langland seems to show little interest in the political prophecy of his day," which was full of such celestial portents and numerological riddles; but when he did, his readers were quick to respond. ${ }^{\mathrm{I}}$

The early fifteenth-century poet of Mum and the Sothsegger was one of them. The narrator of this member of "the Piers Plowman tradition" holds "halfe a-masid" those who "museth on the mervailles that Merlyn dide devyse." ${ }^{\text {I3 }}$ No one knows what tomorrow's weather will be, or can construe what will happen next week:

Thus thay muse on the mase on mone and on sterres

Til heedes been hewe of and hoppe on the grene,

And al the wide world wondre on thaire workes. (173I-3)

The moon and heads that have "been hewe of": this is as close to Langland's "sun [Kane and Donaldson: mone] amiss" and "two monks' heads" as possible without a direct quotation. Closer to the Winchester copyist's milieu, the bodies belonging to these hewn-off heads would materialize, still under that vagrant moon. In 1537, one William Todd, prior of Malton in Rydale, told Cromwell's henchmen that "fourteen or sixteen years ago, he saw in Geoffrey Lancaster's hands a parchment roll 'whereon was a moon painted growing, with a number of years growing as the moon did,' where the moon was full a cardinal was painted, and beneath him the moon waned, and there were two monks, headless, one under the other." ${ }^{\text {I4 }}$ 
Todd's interviewers were hard-wired to be terrified of the popularity of such Galfridian prophecies about moons and body parts, for "prophecies of one kind or another were employed in virtually every rebellion or popular rising which disturbed the Tudor state," prophecies that during this period "circulated extensively throughout the country, particularly in the north of England, where the most active resistance to the government was to be found." ${ }^{\text {"I }}$ Keith Thomas reports upon a classic case of such resistance via prophecy, concerning one John Dobson, vicar of Muston, Yorkshire, that also shows, almost in the comic mode, that "prophecies could thus circulate extensively by word of mouth."

When examined, the priest confessed to having borrowed from the Prior of White Friars, Scarborough, a paper roll made by Merlin, Bede and Thomas of Erceldoune, containing predictions relating to the black fleet of Norway, the eagle, the Cock of the North, the moon, A.B.C., and the various other dramatis personae. The Prior of White Friars was then interrogated and explained that he had copied some prophecies from a priest at Beverley and from William Langdale, a Scarborough gentleman. William Langdale was duly apprehended and confessed to lending the Prior a rhymed prophecy about "A.B.C." and "K.L.M." which he had got from another priest, Thomas Bradley. Bradley pleaded in turn that his prophecies of Merlin and Bede came from William Langley, a parish clerk of Croft. ${ }^{17}$

It might seem surprising to find Piers Plowman caught up in the kind of turmoil that got people like John Dobson executed, but it often seems to present itself as a repository of the sorts of oral wisdom being passed from Langley to Langdale and on, eventually, to poor Vicar Dobson. A number of critics have suggested that many of Piers Plowman's features "imply an audience hearing the text rather than a readership seeing it," 8 and it seems to me that the best such indications are to be found in the records of oral performances. Perhaps William Todd's account seems too far removed from the poem to suggest direct influence, but the sermons of Thomas Brinton, bishop of Rochester from 1373 to 1389 , are not. ${ }^{19}$ While the Winchester passage itself does not seem to have had a life at the pulpit, its close companion does, in a way that points to a new narrative of the post-Reformation Piers Plowman.

\section{John Brynstan, heretic and apostate}

This assertion relies upon my proposed identification of the individual who inscribed the "monks' heads" prophecy into the Winchester 
Anthology. Edward Wilson dates the extract's hand to the early sixteenth century, but it is difficult to know for sure. ${ }^{20}$ It was already there by the time William Way, who refers to "the late bosshop of winton," who died in June 1559 (fol. 191 ${ }^{\mathrm{r}}$ ), inscribed the musical notation that surrounds it; and the hand does not match that of any other contributors. One identifiable owner did not record his name, but jottings of his successor, on the end pastedown, identify him in spectacular fashion: "Johanes Bury[ton] Monacus sancti Swithuuni io y bowthe hym of brynstane coste me $354 \mathrm{~d}$ " ("John Buriton, monk of St. Swithun's, bought it from Brynstan. It cost me three shillings and four pence"; see Figure 7). In lighter ink Buriton later adds "Erytike" under "brynstane" and boxes the two terms, continuing in the same light ink, again boxed, "otherwyse callyd whythere postata." The addendum concludes: "I pray God he may repent and recant." Buriton was a sacrist of St. Swithun's, who also added bits on fols. $\mathrm{I}^{\mathrm{r}}$ and $225^{\mathrm{v}} ;^{21}$ the "heretic" and "apostate" who so arouses his ire must be the "Johannes Brynston," monk of St. Swithun's, who was ordained deacon on December 22, I520, and priest on March 21, $1522 .{ }^{22}$

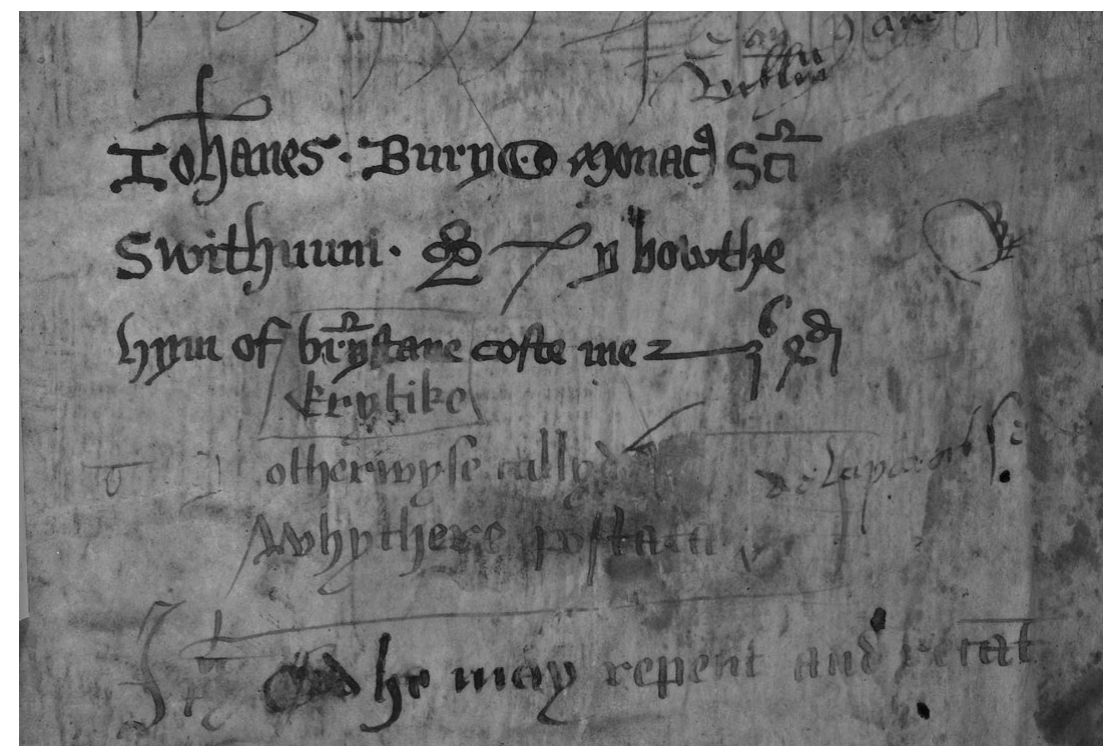

Figure 7 Ownership inscription in The Winchester Anthology. London, British Library, Additional MS 60577, end pastedown 
Wilson draws attention as well to another record relevant to Buriton's remarks, which takes us beyond the realm of Winchester, and either constitutes one of the most bizarre self-contradictions in the history of preaching or indicates a devotion to the prophecies of Piers Plowman. Brynstan's final appearance in the records of St. Swithun's is December 2, I524. Eleven years later, on February I3, I536, according to more of those reports collected by Cromwell's henchmen, an Austin friar named John Brynstan preached a sermon in Glastonbury Abbey church in which, according to one witness, he "said that "he would be one of them that should convert the new fanggylles and new men, other else he would die in the quarrel'," while others added "also that he said that 'all those that doth occupy the new books be lecherous and ready to devour men's wives and servants, and that he would be one of them that would bring down the new books, otherwise he would die in the cause." ${ }^{23}$ Attacks upon the "newfangledness" of "new men" were standard fare in anti-Protestant rhetoric, ${ }^{24}$ and Brynstan's performance would win the Glastonbury abbot a modern reputation in some circles as champion of the true faith in the face of King Henry's tyranny. ${ }^{25}$ Yet these apologies for Catholicism jar violently with the accounts of what he said next:

They all say that the friar expounded the King's title as Supreme Head of the Church to the King's great honor, and the utter fordoing of the bishop of Rome's authority, - quoting Scripture in support of it.

The friar answers that he said, "You with your new books, other ye be adulterers, filthy lechers, devourers of men's wives, daughters, or servants, other full of envy, malice, and strife, and ready to oppress and wrong your neighbours, and that I trusted to convert a great many of such erroneous persons, other to die in the quarrel." 26

"If Brynstan had upheld the king's title as Supreme Head of the Church," Wilson points out, "then such support for Henry VIII would doubtless have caused Buriton (who would have approved of the attack on 'new books') to use the words 'Erytike' and 'postata'." 27 What matters for us instead, though, is the blatant contradiction here between this praise of the king and the invectives against the Protestants. It might seem inviting to cite as a parallel the career of another sixteenth-century scribe of Piers Plowman, Sir Adrian Fortescue, who both held true to his Catholic faith and "conformed outwardly, at least, to the royal supremacy," for instance by copying out in his missal a bidding prayer retaining Henry VIII's title "supreme hede immediately under God." 28 But if Fortescue 
ever accused reformers of devouring men's daughters, no record of it survives; and his missal's reference to Henry's supremacy was later cancelled, its owner being executed in July $\mathbf{I} 539$.

Brynstan's performance begins to make sense, though, if his expounding of the king's title was not an endorsement of Henry's policies, but a prophetic warning against ecclesiastical self-complacency that sounded like this:

but per shall come a kyng \& confesse you relygyouse $\&$ beyte you as pe byble tellethe for breykyng off your ruele $\&$ amend monales monkes $\&$ chanons $\&$ put pem to theyr penaunce ad prestinum statu, ${ }^{29}$

which goes on to predict that the abbot of Abingdon will be disendowed; or, from that king's own perspective, like this:

“... yei beene but membres \& I aboven all.

$\&$ sythe I am your aller heyde I am your aller heale

$\&$ holy cherche cheffe helpe $\&$ chefteyne off pe commune,

$\&$ what I take off you two I take ytt at pe teachyng

Off spiritus justitie for I jugge you all."

If he knew them - and as the next section will suggest, that seems likely, even if he did not know they were from a poem called Piers Plowman Brynstan would have felt that these lines were speaking directly to him, a man so discontent with ecclesiastical abuses that he abandoned the priory.

\section{Davy the Dyker and the abbot of Abingdon}

Nearly all sixteenth-century readers who left records of their responses joined Brynstan (if my attribution is right) in homing in on the "monks' heads" lines. Readers of this era supplied the passage in one A and one C manuscript; ${ }^{3 \mathrm{I}}$ most others juxtaposed them with the "king shall come" prophecies as I have suggested Brynstan did. Two of the three sixteenthcentury full-scale B manuscripts are outliers: Tokyo, Takamiya MS 23 (olim Sion College MS Arc. L.4O 2/E), one of only two witnesses to B that "have virtually no original marginal notes," 32 and Cambridge, Gonville and Caius MS 201/107, which faithfully reproduces Rogers's I56I text and apparatus. The third B manuscript of this era is CUL MS Gg.4.3I, the copy I quoted in the previous section, which calls the 
poem "The Prophecies of Piers Plowman," emphasizing these as two of the poem's five "prophecies" via marginal glosses, a table of contents, and unique symbols enabling cross-referencing between the contents page and the text. ${ }^{33}$

The phenomenon is epitomized in Thomas Churchyard's Davy Dycars Dreame, most likely published three or so years before Robert Crowley's I550 editions. ${ }^{34}$ "And davy the dykar shall dye for hungar," warns "piers plowman" in the Winchester version; in Churchyard's pamphlet this figure speaks for himself, his "dream" expressing the hope for a time "When hongre hides his head, and plenty please the poore, / And niggerdes to the nedy men, shall never shut their doore." Davy also yearns for the fulfillment of the "abbot of Abingdon" passages, when "Rex doth raigne \& rule the rost, \& weeds out wicked men," the first three words forming a refrain that recurred throughout the pamphlets by Churchyard and his opponents in the wake of Davy Dycars Dreame. ${ }^{35}$ From beginning to end, the Davy Dyker sequence uses as its touchstones the two modes of prophecy whose prominence had been signaled by the producer of CUL Gg.4.3I a few decades earlier. And, while Churchyard was indeed a Protestant who supported Edward VI, his broadsides barely engage with religious factionalism. To call them "Protestant" on account of his religion, then, would be not so much wrong as beside the point.

A mid-sixteenth-century compilation of political prophecies, BL MS Sloane 2578, firmly places Piers Plowman's "prophecies" within a Protestant tradition, but even here critics have exaggerated its reformist characteristics. The Sloane compilation includes a number of anti-Marian passages, toward the end of which the "monks' heads" and "there shall come a king" prophecies are not juxtaposed, but combined, in a passage first brought to light by Sharon Jansen (fols. $107^{\mathrm{v}}-\mathrm{IO} 8^{\mathrm{r}}$ ):

Then I warne you workmen, werke while ye maye. For hunger hitherward hastethe to chaste us. Eare v. be fulfilled suche famen shall arise. Thurgh floodes \& fowle wether frutes shall fall, \& so Saturne sende you to warre, when you see the same amys \& too monkes heddes. / And a maide have pe maistery, $\&$ multeply by ryght, then shall deathe withdrawe, $\&$ derthe be justice, then davy pe dygger shall dye for hunger. But if God of his goodnes graunte us a truce. For per shall com a kinge \& correcte, you religious, and beate you as pe byble telles, For breakinge of your rule and nunnes munkes $\&$ Chanons, \& putt pem to pe penance, Ad pristinum statum. / Finis. 
Today we recognize this as a combination of two passages from Piers Plowman, B 6.32I-3I and I0.322-5, but it is not clear that the Sloane copyist did. ${ }^{36}$ The existence of a longstanding tradition, most likely oral in character, that juxtaposed these passages suggests as much. So do his presentation of these lines in prose (others, even on the same page, are in verse) and the presence of unique variants that, as Pearsall observed, point to memorial reconstruction. ${ }^{37}$

Wendy Scase observes that "Jansen did not however notice that these are the same two groups of Piers lines that underpin Dauy Dycars Dreame." ${ }^{38}$ But neither Jansen nor Scase noticed an instance of this combination much closer to hand, in Sloane 2578 itself, to which an early reader or the scribe drew attention by writing "IO2.b" and "IO3.a" in the right margin, directing readers to the Piers Plowman lines (i.e., the modern $107^{\mathrm{v}}-\mathrm{IO} 8^{\mathrm{r}}$ ), and "22.a" (modern 27 ) next to that item in turn (see Figure 8). ${ }^{39}$

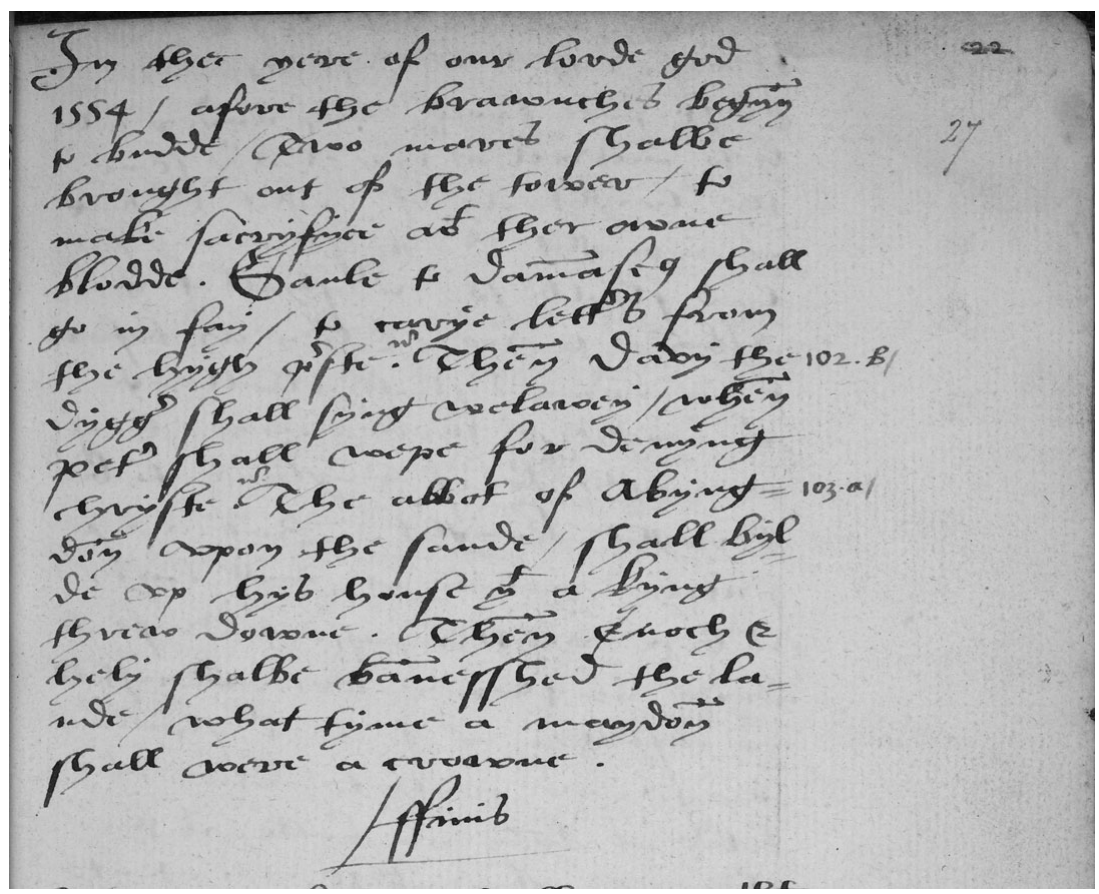

Figure 8 Another "Davy the dykar" poem. London, British Library, MS Sloane 2578 , fol. $27^{\mathrm{r}}$ 
In the year of our lorde god 1554 / afore the brawnches begyn to budde / Two mares shalbe brought out of the tower / to make sacryfyce with ther owne blodde. Saule to Damascus shall go in fay / to carye letters from the hygh preste. Then Davy the dygger shall syng welawey / when Peter shall wepe for denyng chryste. The abbot of Abyngdon upon the sande / shall bylde up hys house pat a kyng threw downe. Then Enoch $\&$ hely shalbe banesshed the lande / what tyme a maydon shall were a crowne. / Finis

These quatrains appear in this form in B.L. MS Harley 559, fol. $33^{\mathrm{v}}$, where they are stanzas three through five; another, six-stanza version is extant as well, even within Harley 559, at fol. $\mathrm{II}^{\mathrm{r}}{ }^{40}$ That this prophecy is so much more faithful to the item's other appearances only underscores the probability that the Sloane Piers Plowman lines were, by contrast, originally copied from memory, either by this compiler or by the originator of the lines in an earlier exemplar.

Witnesses to his sermon said Brynstan cited scripture in support of his description of the king's title as Supreme Head of the Church; it seems likely, this body of evidence suggests, that Piers Plowman, too - or instead, as suggested by "I am your aller heyde" - made an appearance in Glastonbury, even if it was not cited as such. The Winchester Anthology's divergence from the received B 6.328 offers further support: rather than the standard claim that a maid shall "have pe maistrie," Winchester alone says instead she will "bere rule \& reigne," and like the king will come "with crowne the commune to reule."

\section{Robert Crowley and the face of a prophecy}

Regardless of how Davy and the abbot got into the Sloane collection, they do not manifest an inherently Protestant Piers Plowman of their era. Whatever such credentials attach to these items are counterbalanced by the equally staunch Catholic credentials of the Winchester text. Neither CUL Gg.4.3I nor Davy Dycars Dreame suggests that Piers Plowman's "prophecies" were taken to be inherently reformist in the Tudor era. It is important to maintain this perspective for a historically informed account of the most famous sixteenth-century juxtaposition of the "monks' heads" / "there shall come a king" modes, Robert Crowley's, the sixth member of the tradition traced here. Crowley cites only two passages in his preface to his I550 editions: the opening, which exemplifies alliterative meter, and the "hunger prophecy." Unlike the other versions, this instance distances Langland from the passage's sentiments: 
As for that is written in the .xxxvi. leafe of thys boke concernynge a dearth then to come: is spoken by the knoweledge of astronomie as may wel be gathered bi that he saith, Saturne sente him to tell. And that whiche foloweth and geveth it the face of a prophecye: is lyke to be a thinge added of some other man than the fyrste autour. For diverse copies have it diverslye. For where the copie that I folowe hath thus:

And when you se the sunne amisse, \& two monkes heades

And a mayde have the maistrye, and multiplie by eyght.

Some other have,

Thre shyppes and a shefe, wyth an eight folowynge

Shall brynge bale and battell, on both halfe the mone. (sig. ${ }^{*} \mathrm{ii}^{\mathrm{v}}$ )

Crowley's conclusion that the verses are not Langland's rests on the dubious logic provided by what we would now call the C-text version of the passage. ${ }^{4 \mathrm{I}}$ Still more remarkable is the fact that he feels compelled to say this at all: his Langland would not indulge in such puffery. In his second and third editions, seeming to have forgotten his earlier claim that this passage had the face of a prophecy and thus must have been an intrusion, Crowley newly annotates it so as to underscore his refutation of this tradition: "This is no prophecy but a pronostication." ${ }^{2}$

The standard explanation of Crowley's disattribution of the "monks' heads" passage from Langland is that "the reader is not to read this text as if it were a prophecy of Merlin, or one of the other medieval prophetic texts sixteenth-century reformers associated with paganism." ${ }^{43}$ But only ten or so of Piers Plowman's 7,00o-plus lines might court such a response: why, then, is Crowley so worried? ${ }^{44}$ And why does he continue immediately with a denial of any prophetic status to the non-Merlinesque "there shall come a king" lines?

Nowe for that whiche is written in the ll leafe, concernyng the suppresson of Abbayes, the Scripture there alledged, declareth it to be gathered of the juste judgment of God, who wyll not suffer abomination to raigne unpunished. Loke not upon this boke therfore, to talke of wonders paste or to come but to emend thyne owne misse, whych thou shalt fynd here moste charitably rebuked. $\left({ }^{*}\right.$ ii $\left.^{\mathrm{V}}\right)$

The passage is very odd, especially given the general assumption that Crowley exemplifies this era's belief that Langland was a prophet. This passage suggests exactly the opposite: about the "king shall come" lines Crowley says merely that Langland has cited ("alledged") a scriptural passage to the effect that sins will be punished. Indeed he adjures his readers not to 
look for wonders "to come" in these pages: as James Simpson observes, "Despite some annotations that point to Piers as prophetic, Crowley himself was less inclined to read the poem as prophecy, and more as offering a powerful example of courageous protest, whose force was still relevant." 45

Crowley's careful account of his quest for the poet's identity, Thomas A. Prendergast argues, is intended primarily to promote this dissociation. Such prophecies were often "craftily hidden in some old stonie wall, or under some altar, or in some ancient window," as the physician John Harvey (whose brother Richard owned Owen Rogers's I56I edition of Piers Plowman) wryly noted: "The text of Piers, on the other hand," says Prendergast, "is manifest and actively sought - Crowley endeavors to gather together "such aunciente copies' as he could come by." So too the insistence on dating the poem, and on the ancientness of his sources, was a pre-emptive strike against any accusation of "newfangledness" of the sort that John Brynstan found in the Reformists: "the claim is that the texts that illustrate the existence of the new religion are not 'new' either." ${ }^{46}$ What Prendergast says would apply as well to the very form of Crowley's Piers Plowman, which, I would suggest, constitutes a response in opposition to, rather than exemplification of, an oral tradition of the "prophecies of Piers Plowman." In particular, the bookish paraphernalia of his edition - its preface and apparatus of marginal commentary - attempt to re-textualize Piers Plowman in the face of its wild (and oral) ride from Langland's pen to the House of Fame, on which route it had visited the Mum-author, John Brynstan, and Cromwell's interviewees, and, eluding Crowley's grasp, would soon head for the Sloane compilation. Crowley, in sum, attempts to restore these free-floating passages about monks' heads and chastizing kings to their scripted, non-"prophetic" contexts.

The phenomenon against which Crowley's performance calls to be interpreted left very few traces behind, and would still remain hidden if the newly uncovered instance in the Winchester Anthology had not brought it into focus. We can now go much further than the claim that Crowley's readers are not to see Piers Plowman in the light of Merlin's prophecies: nor, it seems, are they to read it as if it were the Piers Plowman whose textual remnants survive in the amalgamation of prophecies in Davy Dycars Dreame, the two items in the Sloane collection, and Brynstan's productions. Crowley is rescuing Langland from "Piers Plowman": these words are no longer prophecies uttered by that gnomic character, as in the Winchester Anthology, but instead the intelligent prognostications by the historical poet Langland (when concerning disendowment), and, at least when Crowley remembered, intrusions from someone else (when making wild claims about monks' heads and the sun amiss). 
My proposal calls for a revision of the notion that "Crowley's reformist interpretation" of the poem "marks the culmination of the Piers Plowman apocrypha that had grown up during the previous two centuries," which has served in effect as the default sixteenth-century instantiation of the poem. ${ }^{47}$ We have already seen that the generally accepted relationship between Davy Dycars Dreame and Crowley needs to be reversed; and even the Sloane compilation, pace the beliefs of a number of critics, bears no trace of his influence. ${ }^{48}$ The one intriguing textual variant shared by the (pre-corrected) Winchester lines and the preface (but not text) of Crowley's third edition, "three" for "two," is certainly coincidental. ${ }^{49}$ And, while Bryan Davis remarks in passing that the compiler of the sixteenth-century Cambridge manuscript "constructed a reading of Piers Plowman that dislocates the poem from its tantalizingly topical context and shifts it closer to the context of reformist, prophetic rhetoric into which the poem was inserted by Bale and Crowley," "we should now accept the logic against which this observation is working: that manuscript might be "prophetic" in other ways, but not this one. Crowley was looking back at that document - literally, that is, for he seems to have consulted it once before preparing his first edition, and again when preparing the second edition ${ }^{5 \mathrm{I}}-$ but its producer was not looking forward, or even, probably, outward.

The revision of the post-Reformation Piers Plowman should extend to our assessment of its religious affiliations. Reformers might have embraced the figure of Piers the Plowman, but those engaging with the poem in which he first appeared did not necessarily adopt such an approach. Crowley is not an exception to this trend: the standard narrative has it that he was following the lead of his collaborator and colleague John Bale, who wrote, "In this erudite work [sc. Piers Plowman], beside the various and delightful allegories, he prophesied many things, which we have seen come to pass in our own days," ${ }^{\prime 2}$ but as Larry Scanlon has pointed out, only I5 of the 495 glosses, 3 percent, of Crowley's third and most heavily glossed imprint are explicitly anti-Catholic. ${ }^{53}$ Nor is his text itself, as opposed to the apparatus, any more "reformist" than Langland's own, as R. Carter Hailey conclusively demonstrates. ${ }^{54}$

\section{Catholic Piers Plowman in the sixteenth century}

This absence of a strongly Protestant Piers Plowman right where we thought it to be not only present, but predominant, is not as surprising as it might appear; John Brynstan is not the perverse anomaly he would 
have been were the assumption that the sixteenth century was home to "Piers Protestant" and no other version of the poem accurate. As the only "striking exception" to what she claims to have been the poem's otherwise exclusively reformist reception history from 1400 to 1600 , Anne Hudson identified, from the I530s or later, The Banckett of Johan the Reve unto Piers Ploughman, Laurens labourer, Thomlyn tailyer and Hobb of the hille with other, in BL MS Harley 207. ${ }^{55}$ Yet there were others, in addition to Brynstan. In I6I3 one Andrew Bostock entered marginalia into his copy of Crowley, "return[ing] to the traditional interpretation of Piers Plowman as an orthodox appeal for reform within the established church." ${ }^{6}$ Nor, of course, was Sir Adrian Fortescue any stooge for Henry VIII in making his copy in 1532 (see note 28). And New Haven, Yale Beinecke MS Osborn a.I8, a handwritten pamphlet of the 1580 s, purports to offer Piers Plowman's consolation to Catholic martyrs, which a later Protestant hand describes instead as a way to indoctrinate papists in the ways of treachery. The Winchester Anthology was just one of many homes of a Catholic Piers Plowman in the era of the Reformation.

Those two monks' heads played no less prominent a role in the reception history of Piers Plowman than did the real-estate losses of the poor abbot of Abingdon: the "prophecies" that sixteenth-century audiences in particular embraced were not the sole provenance of the latter mode. We need, as Richard K. Emmerson has commented, "to trace the reception of Piers Plowman diachronically, to place the later ideological readings by Crowley and other Protestant polemicists if possible within a more continuous tradition. We need to determine the extent to which contemporaries and near contemporaries received the poem as a species of prophecy." ${ }^{\prime 7}$ We need, in other words, readings of late medieval and early modern culture that do not advert to a Langland archive that tells us what we already "knew": that from 1530 Piers Plowman was Protestant. For the tradition tracked here is one against, not within, which Crowley sought to place his work. This is a haunted land with which critics today are about as comfortable as was the author of Mum and the Sothsegger or indeed Cromwell himself; we would rather discuss the politics of ownership than celestial portents and visions of headless bodies or bodiless heads.

To ignore those Merlinesque passages, though, is to misrepresent the sixteenth-century Piers Plowman not because a focus on Crowley is partial, but because they are so crucial to his enterprise to begin with. The full respect that all these figures accord the monks' heads passage, quite apart from its context in the narrative of the "Visio," might result in a picture of 
a poem far from the literary full-length masterpiece we usually study, and that the producer of Gg.4.3I copied and Crowley edited. But both Mum and the Sothsegger and Piers Plowman itself suggest that this disembodied collection of texts, whether or not prophesying any wholesale reform of the church, was not an invention of a Tudor pamphleteer, or a monk-turnedapostate-friar, or a political-prophecy obsessive, or an indexer/cross-referencer/copyist, or a reformist "rescuer" of the poem. Rather, these texts were always present in Piers Plowman, newly brought to the light of the sun amiss, away from the gaze of the poem's archons. 


\section{Urry, Burrell, and the pains of John Taylor: the Spelman MS, I709-I766}

Werewolves, accessories to murder, decapitated rebels, drunken annotators, heretical apostates: even if most of these figures' connections with Piers Plowman remain shadowy, they still demand our attention. By contrast, what is generally taken to be "a comparatively fallow period for Piers Plowman textual scholarship," that between the editions of Crowley (I550) and Thomas Whitaker (I813), might not seem to offer anything comparably engaging. The truth, though, is that this era's fabricators of the Langland archive are no less intriguing, and much better defined, than their predecessors. Even the one major bore at the heart of the story this chapter will tell is superlative in his dullness, and his companions here include maligned non-juring editors, dissipate viscounts, hapless librarians, insane antiquarians, and others who despite their obscurity are central to the creation of Middle English studies. For the eighteenth century is the era in which the world we study came into being as a projection of scholarly desires and an object of its methods. To locate the authentic Piers Plowman solely in the manuscripts and editions is to remain beholden to many layers of transmission whose existence is neglected. Yet our analyses are the products as well of the intervening centuries' engagement with the textual record. "If we hope to understand the medieval manuscripts that we study and the manner in which we study them," observes Jennifer Summit, "we must begin by asking where they came from" - not just where they originated, but also their subsequent sojourns in the libraries of owners and institutions, out on loan or hidden from view. ${ }^{2}$

The first half of this chapter concerns the ways in which readers and scholars of the eighteenth century could consult, or just know about the existence of, the texts of Piers Plowman. The focus will be the document that is now San Marino, Huntington MS Hm II4 (sigil Ht for Langland's poem). Though its text barely figures in modern editions, this was by far the most important copy in the earliest stages of serious textual work on the poem. In tracking its movements, we will keep encountering evidence 
of the partiality of our received archive of primary texts, quite apart from the absence of manuscripts lost to early neglect, disaster, and Cromwellian destruction. In general, the post-Crowley era witnessed the steady consolidation of materials in the hands of the major collectors like Robert Cotton or Edward Harley and by the major repositories of the British Museum, the Bodleian, and Cambridge University Library. This chapter bears witness to some of those developments, which must remain at the heart of our histories of textual transmission and scholarship. But the company kept by $\mathrm{Hm}$ II4 alone shows the partiality of any account that looks only there. Manuscripts now lost or not readily identifiable, important volumes erroneously catalogued, and unexpected auctions associated with $\mathrm{Hm}$ II4 and its peers disturb any attempt to form a coherent image of the eighteenth-century Piers Plowman. These items' resistance to any accommodation by the historians and fabricators of the Langland archive - in this case, their resistance to the original goal of this chapter, the mapping of the eighteenth century's increasing interest in the text of Piers Plowman - underscores the imperative not to write them out of our story.

\section{Lord Weymouth, John Urry, and the Spelman auction of 1709}

The Piers Plowman text of Huntington Hm II4 is notorious both for its modernization of the language and, especially, for its conflation of all three versions so as to form a massive text, which have kept this copy on the outskirts of Langlandian editorial history. ${ }^{3}$ But students of the poem's production and transmission have made great strides, focusing on what exemplars the scribe had to hand, how he treated them, and, most recently, his identity: according to Linne Mooney and Estelle Stubbs, he was Richard Osbarn, the clerk of the Chamber of the City, I400-37, in which capacity he was colleague of John Carpenter, John Marchaunt (Scribe D), and the other figures involved in the promulgation of vernacular poetry in the early fifteenth century. ${ }^{4}$ This document's post-medieval history, though, has not attracted such close attention. The Huntington Library's catalogue of manuscripts and its derivations rely entirely on the inscriptions within the manuscript itself in relating its provenance, thus identifying no owners between the antiquarian Henry Spelman (?1564-164I) and Dr. John Taylor (I704-66), the two inscriptions on folio $\mathrm{I}^{\mathrm{r}}$ (see Figure 9). ${ }^{5}$

But evidence external to the copy indicates that it was among the twenty or so volumes that Thomas Thynne, first Viscount Weymouth (I640-17I4), purchased at the two auctions of Spelman's collection by the bookseller John Hardyng, held in December 1709 and January I710. ${ }^{6}$ The discipline of Middle English studies thus owes almost as much to his efforts, which established the great collection at Longleat House, as to those of another 


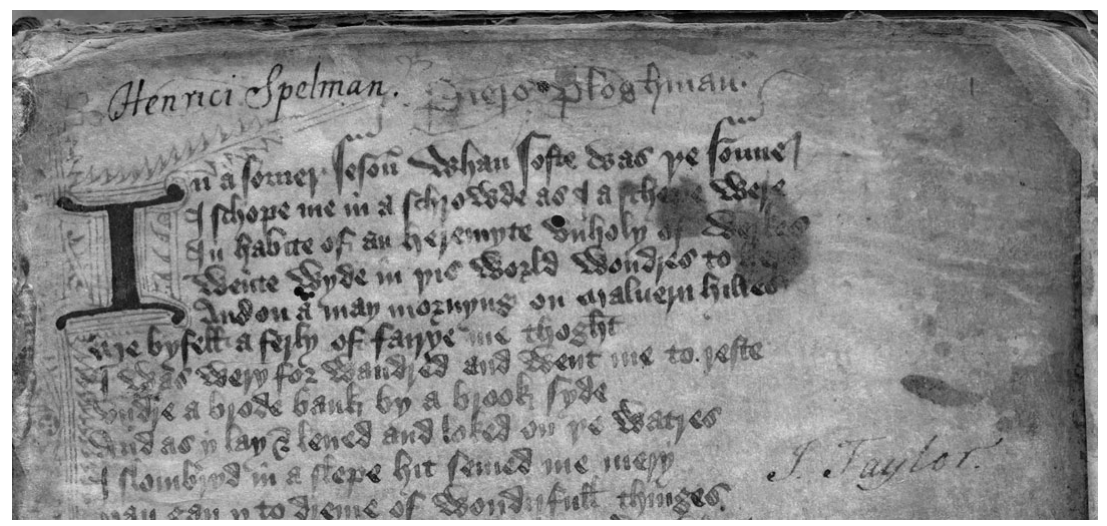

Figure 9 Ownership inscriptions at the opening of Piers Plowman. San Marino, Huntington Library, MS Hm II4, fol. $\mathrm{I}^{\mathrm{r}}$

member of an earlier generation of his family, the sixteenth-century Chaucer editor William Thynne. Though no longer in the Longleat collection, the manuscript's inclusion among these items is indicated by Timothy Thomas's Preface to John Urry's Works of Geoffrey Chaucer, published posthumously in I72I: "The Reader will observe MS. Sp. often quoted in the Glossary, by which is meant a MS. in Octavo partly written on Velom and partly on Paper, containing the Five Books of Troilus and Criseide. This I found amongst Books and Papers left by Mr Urry; but I could not perceive that he had made any use of it." At first Thomas "did not know to whom it belonged," but was eventually able to piece together its provenance:

it seemed to have once belonged to that Learned Antiquary Sir Henry Spelman, his name [Henrici Spelman] being written in fair hand on the first leaf of it, and at the beginning of other Tracts contained in that Volume. But I have been since informed that it belonged to the late Lord Viscount Weymouth, from whom it is probable Mr. Urry borrowed it not long before his Death; which might be the reason that no notice is taken of it in that Catalogue he left of the MSS. which he had seen and perused.?

Urry had cut his editorial teeth on the I7IO edition of Gavin Douglas's Eneydos. He undertook to edit the works of Chaucer "much against his inclination," the task thrust upon him by "some Persons, [who imagined themselves] well acquainted with Mr. Urry's Qualifications" and who saw this as a potential way to raise funds for Christ Church. ${ }^{8}$ Thomas's list reveals that, in addition to $\mathrm{Hm}$ II4, Urry had access to another Troilus lent by the first Viscount Weymouth, a Canterbury Tales lent by the widow of 


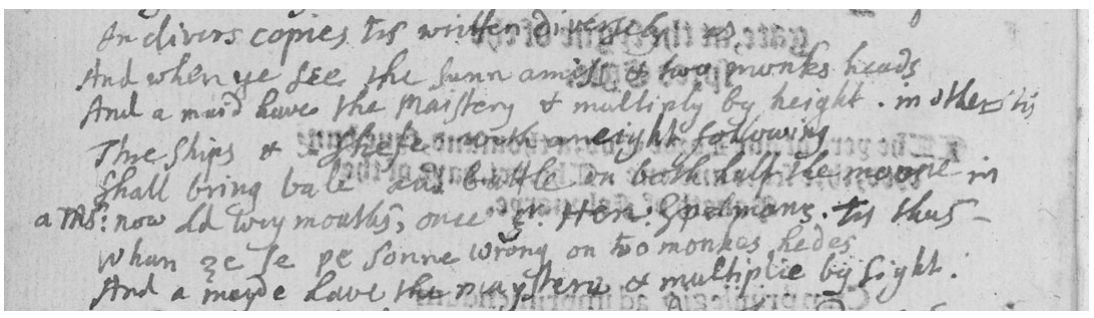

Figure Io Urry's reference to the Spelman MS in his transcription of Crowley's preface. Oxford, Balliol College 525.a.I, verso of title page

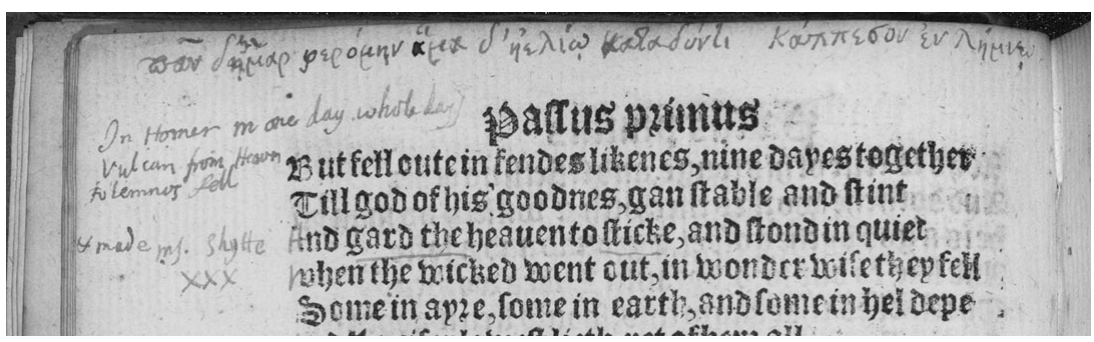

Figure II Urry's comparison of Piers Plowman to Homer. Oxford, Balliol College 525.a.I, sig. B.ii ${ }^{\mathrm{v}}$

his son Henry, and another whose loan was arranged by George Harbin, Lord Weymouth's librarian.? Kate Harris points out that "Urry (like the Ist Viscount Weymouth) was of Christ Church, matriculating in I682: he was deprived of his studentship on the accession of William III for his refusal of the oath of supremacy. These two reasons alone may be enough to explain his becoming a recipient of Weymouth's patronage."

It appears, though, that Urry took a greater interest in the Piers Plowman text of the Spelman/Weymouth MS than in its Troilus. The library of Oxford, Balliol College, contains a copy of Owen Rogers's 156I Vision of Pierce Plowman in which Urry, whose hand I identified in his signed transcription of the Canterbury Tales, now BL Additional MS 38I78, loosely transcribes Crowley's address to his readers onto the verso of the title page, into whose discussion of the ubiquitous "monks' heads" prophecy he inserts reference to the reading of "a MS: now Ld Weymouths, once $S^{\mathrm{r}}$ Hen. Spelmans" (see Figure IO). Ensuing annotations reveal some interest in Piers Plowman's literary milieu, the reference to the devils' nine-day fall from heaven (B I.I2I) prompting the comment, "In Homer in one day whole day Vulcan from Heaven to lemnos fell" with the appropriate Greek line 
inscribed atop the page (see Figure II). On the one hand, this gloss is the only comparison of Piers Plowman to Homer I have ever encountered, and as such occupies a noteworthy place in the history of Langland scholarship; on the other, it just shows that Langland was more fully incorporated into the larger intellectual streams of the age than has been known, ones in which Joshua Barnes's I7II edition of Homer was causing such a stir. ${ }^{\text {II }}$

Urry's particular focus in this volume is the collation of this Rogers against the text of the Piers Plowman text in the Spelman/Weymouth copy throughout the Prologue and passus I. He inscribes that manuscript's distinctive lines - most from the $\mathrm{A}$ or $\mathrm{C}$ versions represented in Ht's collated text, a few unique to it - in the margins, and he marks variants, as in MS made and shytte for the Rogers gard and sticke in Figure II. After passus I the only such instance is the hunger prophecy, unsurprisingly given his inscription of Crowley's preface as cited above, where Urry records one small variant and inscribes Ht's unique line after the end of passus 6: "And shild us from his vengiaunce, while that we bene here. MS." This is something of a milestone in the history of Langlandian textual criticism. Robert Crowley did his share of comparisons among manuscripts, but not, so far as we can tell, as systematically as this. ${ }^{12}$ Urry's approach to Langland was in line with the work he did in preparation for the editing of Chaucer. William L. Alderson observes that, like other editors of his era, Urry "appears to have carried out his collation by noting various MS readings in the margin of his own copies of earlier printed texts. A 156I Stow is extant in which Urry's collation of that text with several MSS is identifiable"; and Simon Horobin has now identified a Speght that he collated as well. ${ }^{\mathrm{I}}$ Yet the result was an edition of Chaucer whose reputation as "by far the worst that was ever published," in Thomas Tyrwhitt's words, has dogged it from the time of its publication to today. ${ }^{14}$

Some might wonder, then, whether his low place in the annals of Chaucer scholarship downgrades his importance to Langland scholarship as well. But each of the critics who voiced this cliché has a different agenda, which is rarely to discuss the quality of Urry's edition. John Dart, who supplied the edition's biography of Chaucer, for instance, declared in 1723 that he was not "willing to buy it, when my old one, with my own written Notes, serv'd me as well" - but he was bitter about the whole experience, feeling "ill return'd by this ungen'rous Age / Unthank'd the Labour, and defac'd the Page." "' In 1736 Thomas Morell called Urry's text "the worst that is extant," but his criterion was the fact that John Entick, his fierce opponent, rival as next potential editor of Chaucer, and addressee of this 
claim, implicitly endorsed the edition - for Urry's was worst, he clarifies, "except the little I have seen of your's." ${ }^{\text {"I }}$ Joseph Ritson called the edition "very pompous, and most inaccurate and licentious" in I802 - but he seems offended by its appearance in folio; he is eager to bolster his preferred edition of Tyrwhitt, whose text was "settled by an indefatigable collation of all the printed and MSS. copyes"; and he is the most irascible scholar ever to have published on medieval literature. ${ }^{17}$

This level of anger is difficult to account for: the worst that can be said for Urry's approach to the normalization of the text is that the edition does not indicate his emendations, in the form, usually, of added prefixes or filler words to normalize the meter. But that is the fault of the editors who brought out the text six years after his death. In any case, the lack of any such brackets in The Riverside Chaucer has not incited equivalent complaints. ${ }^{18}$ Alderson's observation that "few men have felt it necessary to study the edition before condemning it out of hand" is justified. ${ }^{19}$ And such condemnation has obscured the fact that Urry was a pioneer in a mode that is potentially of far greater value to scholars today, the one in which we ought to situate his work on Langland: his collation of multiple manuscripts. Ritson's implication that Tyrwhitt was the first Chaucer editor to give due attention to the manuscripts and printed editions in fact indicates how poorly those who saw Urry's work into print executed their responsibilities. Ritson was surely appalled to find no indication that Urry consulted any manuscripts in Oxford, but their absence from Thomas's account was a simple oversight. ${ }^{20}$ Alderson remarks about this "ground-breaking survey of MSS": "The Urry-Thomas list of Chaucerian MSS in the 172I preface is impressive, if only for the large group of MS texts which are here for the first time brought into close association, clearly located, and described in some detail."

The discovery that John Urry collated his 156r Vision of Pierce Plowman against a manuscript, any manuscript, of the poem only underscores the evidence that he was ahead of his time in recognizing the need to consult manuscripts far and wide. It also suggests in turn that our sense of Langland's distance from Chaucer in eighteenth-century scholarship is not quite right. For what would have prompted Urry to engage in so systematic a collation? Crowley's remarks about the "monks' heads" prophecy obviously attracted his attention, but on their own they point only to a few lines in passus 6. Our knowledge that Crowley consulted other copies comes not from any explanation by him, but via our own collation of his text with the manuscripts. We are now so accustomed to the idea that engaging with the variant states of Piers Plowman's texts is just what one 
does with them that it is easy to overlook how foreign such a notion would have been three hundred years ago. Urry's experience with Chaucer taught him about the reality of manuscript variation, which he found manifested in the Langland archive as well. He probably did not notice any greater number of differences between the Spelman/Weymouth and Crowley texts than among the Chaucer manuscripts, since, as George Russell and Venetia Nathan remarked in their own groundbreaking essay on Ht, "the text of the Prologue is unique in the early part of the poem in that it shows no evidence of any substantial use of material from A or C," and passus I has only one substantial non-B passage, $\mathrm{C}$ I.II2-25, just after the lines on Lucifer's fall, of which Urry transcribes the first four lines at the bottom of the page, not seeming to notice the remainder. ${ }^{22}$

Had he only continued one more passus, the wildness of the Spelman/ Weymouth copy would certainly have become apparent - over thirty $A$ and twenty $C$ lines are added to the $B$ text of passus $2^{23}$ - and any number of possibilities might have eventuated: Urry might have considered $\mathrm{Ht}$ to be an authorial text, or followed Crowley in distancing Langland from the variants, or sought out more manuscripts, or even, if not defeated by Chaucer, undertaken the first new edition of Piers Plowman since 1550 . Instead, it seems, he dutifully returned to his Chaucer and then died prematurely, Christ Church eventually reaping the benefits of his work and subsequent critics taking their pleasure in carping. Urry left behind, as would so many others in the vein of Joseph Ritson, frustrating and unfulfilled potentialities, poised just on the threshold of a serious understanding of Piers Plowman's textual states. But, more important, he also bequeathed new evidence, among the earliest, for the facts that scholars were tentatively investigating that variation in the Langland archive much earlier than previously known, and that Crowley's edition did not crowd its manuscript predecessors from the scene.

\section{The pains of John Taylor}

John Urry's collation was just the beginning of what I will call, following Urry, the "Spelman MS"'s role in the formation of modern textual scholarship on Piers Plowman. In fact it pales in comparison to our next episode, the best introduction to which is a remark by Richard Farmer (1735-97), librarian of Cambridge University, noted Shakespearean, and great book collector, on a flyleaf in his own 156I Rogers: "Dr. John Taylor took much pains with this Book." ${ }^{24}$ Taylor, we remember, was the first owner after Spelman to inscribe his name into Huntington Hm II4. Assiduous and 
dutiful are perhaps the best descriptors of "the most silent man, the merest statue of a man" Dr. Johnson claimed ever to have encountered. ${ }^{25}$ In his capacity as Farmer's predecessor as Cambridge University librarian, in the I730s, "or rather before, and perhaps after, he took great pains" - the motif here articulated by Gentleman's Magazine editor John Nichols (I745-1826) "as did some others, before Booksellers were obliged to be called in, in classing the noble present of George I. to the University, consisting of 30,000 volumes of the best books, besides MSS. formerly belonging to Bp. Moore." ${ }^{26}$ His earliest engagement with Piers Plowman was around I730, the date he records on the inside front cover of his copy of Rogers, now Oxford, Bodleian, $4^{\circ}$ Rawlinson 274.

This volume's abundant flyleaves provide perhaps the first summation of scholarship of the poem, in what Nichols describes as Taylor's "large, fair, elegant hand." ${ }^{27}$ Its contents are impressive by any standard, especially so early in the poem's critical history: a transcription of Crowley's preface to the reader (fols. ii $^{\mathrm{r}}$, iii ${ }^{\mathrm{r}}$ ), a list of the various "John Malverns" who might be candidates for the authorship $\left(\mathrm{vi}^{\mathrm{r}}, \mathrm{xiv}^{\mathrm{r}}-\mathrm{xv}^{\mathrm{r}}\right)$ ), a catalogue of the "plowman" poems he has encountered (I playne Piers etc.; $\mathrm{ix}^{\mathrm{r}}-\mathrm{x}^{\mathrm{r}}$ ), an explanation of the use of the caesura in various manuscripts (xxxviii ${ }^{\mathrm{r}}$ ), transcriptions of the glossaries found in CUL MS Ll.4.I4, fols. $169^{\mathrm{v}}-70^{\mathrm{v}}$ and in Wolfe's 1553 edition of the Crede $\left(\mathrm{xl}^{\mathrm{r}}-\mathrm{xli}^{\mathrm{V}}\right)$, and comparisons of a few readings against four manuscripts over the opening pages of the Prologue and the interleaves there. Most important, and a focus later in this chapter, is his notice of the "MSS Copyes of our Author." Much of this is in Latin, and there are a few specimens of Byrom's shorthand, of which Taylor "was a perfect master," and "which he looked upon as barely short of perfection," as well. ${ }^{28}$ Other than actually reading and analyzing the contents of the poem, activities in which few scholars of this era were much interested, it might be difficult to imagine what remained.

Yet this would serve as mere preparation for an extraordinary episode of textual scholarship, far beyond what Urry achieved with Langland or Chaucer, whose only rivals are to be found in the careers of George Kane and A. V. C. Schmidt. For the Bodleian also holds a copy of Crowley's third edition so heavily interleaved and annotated that the formerly slender volume has turned into two separate and very thick items, now $4^{\circ}$ Rawlinson 272/273, whose title page includes signatures of Taylor, one "John Campion" in a much earlier hand, and William Burrell (1732-96), "a Gentleman Commoner of this College ... and a very particular friend of mine," wrote Taylor, who taught Burrell at St. John's College from 1749 to $1755 .^{29}$ 


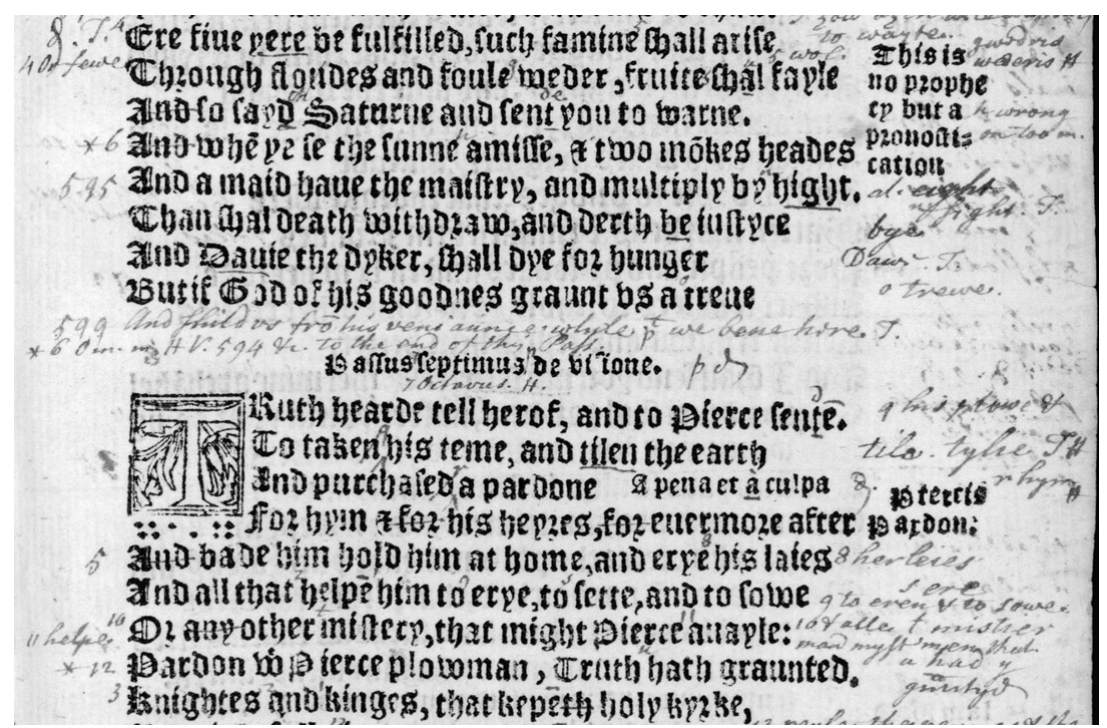

Figure I2 Burrell's collations of Cr with the Spelman and Harley MSS. Oxford, Bodleian Library $4^{\circ}$ Rawlinson 272, sig. I.iv ${ }^{r}$

It is Burrell's hand that fills up the two volumes, most likely, it would seem, in execution of a task set by his tutor. The verso of the interleaf facing the Prologue has a box with two nota benes that explain all the marks:

The Readings markt $\mathrm{H}$ or with.I.2.3.\&c. are out of a Fragment in the Earl of Oxfords Library 62.B.I6. containing Passus.I.2.3.4.5.6. \& part of the 7th. being 22 Leaves in Fol. minoris. Formæ. Membr:

The various Lections markt with the Letters. a.b.c. \&c are taken from a MSS. in 8vo. written partly on Vellum partly on Parchmt. which has $S^{r}$ H. Spelmans Name frequently wrote in it with his own Hand, containing besides, Chaucers Poem of [blank] \& Criseide. \& another called Susanne. $\&$ which now belongs to Lord Weymouths Library. markt T.

Burrell, that is, compared his text to those of what is now BL MS Harley 875, MS $\mathrm{H}$ for us today as for him, and the Spelman manuscript, marked "T," presumably for "Thynne." The "two monks' heads" passage at the transition from passus 6 to passus 7 exemplifies the results of his work. The term Ere opening the top line of Figure I2 is marked 4 to its upper left, and keyed to Harley 875's "Or fewe" in the left margin; weder in the next line is marked $g$, and keyed to T's "wedris" and H's "wederis" in the right margin. What Burrell has signaled as lines 594-9 are omitted in $\mathrm{H}$, as indicated by the asterisked note 
attached to item 6; and all the readings underlined in the rest of passus 6 's lines have the variants in $\mathrm{T}$ as indicated in the right margin ("sight" for hight, "bye" for be; "Daw" for Davie; "trewe" for treue). In the opening lines of the following passus both sources of collation are extant again, the variants keyed by number and letter intermingling in the right margin.

Such crabbed minutiae give way to beautiful, straightforward transcription for those lines absent from Crowley but in the Harley and Spelman manuscripts, as with the latter's unique line, "And shild us from his veniaunce while pat we bene here. T.," the one Urry added to Crowley's account, at the end of that passus. Longer passages, such as the famous opening of C passus 5 (fol. $2 \mathrm{O}^{\mathrm{v}}$ of the Spelman MS; “All om. in H"), allow him to take flight, often over multiple pages (see Figure I3). When neither manuscript provided any source of collation, Burrell turned to a different source. At B 8.104-8 (= IO3-7 by his reckoning; sig. L.i ${ }^{\mathrm{r}}$ ), for instance, where $\mathrm{H}$ is no longer extant, he indicates that $\mathrm{T}$ omits lines but he still adds some collations, here from $\mathrm{Cr}^{\mathrm{I}}$, in the margin: "beede" against the text's byd in the third-to-last line of the passage; "unto them a K_" against its one to be kynge in the final line. Burrell's use of the Harley manuscript also explains the series of eighteenth-century inscriptions in the top margins of its folios $17^{\mathrm{r}}, 18^{\mathrm{r}}, 19^{\mathrm{r}}$, and $2 \mathrm{I}^{\mathrm{r}}$. On the first of these, which begins with A 7.3, for instance, he writes "Pass. 6. V.2." This is not an error, but an indication of the last line missing from Harley as the result of a lost leaf (A 6.49-7.2, the last of which is equivalent to B 6.2). He records the situation as well in the Crowley itself, at the location where $\mathrm{H}$ becomes defective (Rawlinson 272, sig. H.i ${ }^{\mathrm{r}}$ ): "Wanting in H. to Passus Sextus V. 2 (I suppose Pass. 7 in H.) a leaf or two being lost"; then at B 6.3, the difference between the passus numbering of the Harley and Spelman copies finally defeating him: "H continues here, which I suppose in H. Passus Sextus verse 3."

Such a level of commitment is unprecedented. Urry came nowhere close. Neither would Thomas Percy or Thomas Tyrwhitt in later years, whose own collations of Crowleys for the Prologue and first passus have led some modern critics to suggest that they might have considered editing the poem. ${ }^{30}$ This was good practice for Burrell's later devotion to his history of Leicestershire, in which he showed himself to be "exceptionally diligent in collating his materials." ${ }^{31}$ And he did all this before he was twenty years old. One startling terminus ante quem will occupy us in a few pages, but another is the sale of the earl of Oxford's library to the British public in 1753. Even if Burrell's description of MS $\mathrm{H}$ as belonging to "the Earl of Oxfords Library" were taken to be a somewhat out-of-date way of saying "the Harley collection," it seems very unlikely that either he or 


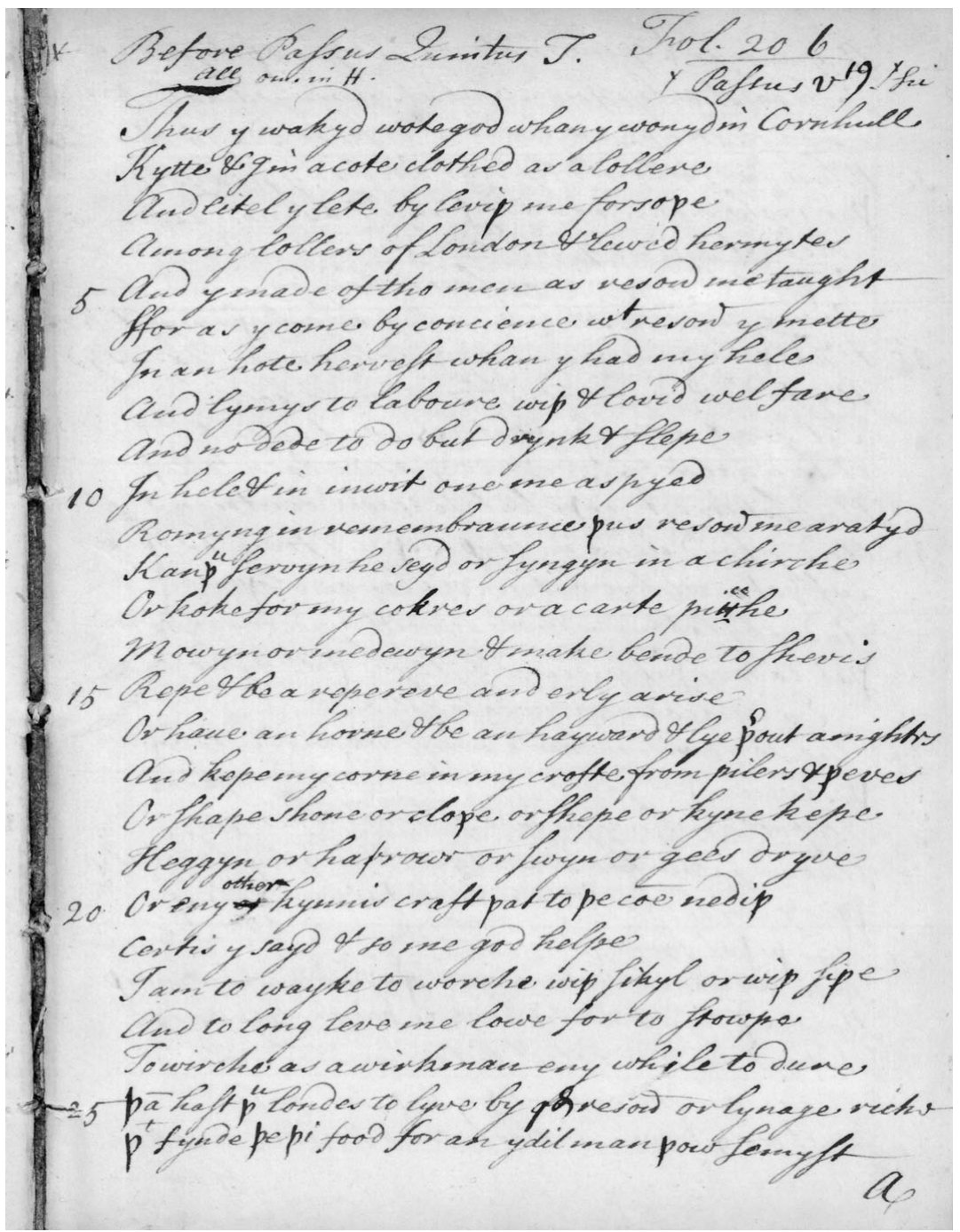

Figure 13 Burrell's transcription of C 5.I-27 (omitting 2I) from the Spelman MS. Oxford, Bodleian Library $4^{\circ}$ Rawlinson 272, flyleaf after sig. E.iv ${ }^{\mathrm{v}}$

Taylor could have had access to it after that sale. But a date of $c .1749-52$ would not have been a problem: in 1734 Taylor even composed a poem on the occasion of the marriage of Lady Margaret Harley, who was the one who would later, as duchess of Portland, sell the Harley collection to the British public. ${ }^{32}$ 
More intriguing is the status of the Spelman copy, which, while certainly in Taylor's collection on his death in 1766, whence it went to Anthony Askew, ${ }^{33}$ was at this point still in the possession of the Weymouth family, having been returned upon its discovery among Urry's papers. Taylor had an intimate relationship with this clan: his patron was John Carteret, second Earl Granville, the maternal grandfather of Henry Frederick Thynne (1735-1826), and Thomas Thynne (1734-96), grandnephews of the first viscount, the latter of whom became third Viscount Weymouth in 175r. Granville "laid the plan, and suggested the methods, of their education," entrusting the task to Dr. Taylor, under whose auspices the brothers matriculated at St. John's in $1752 .{ }^{34}$ There are any number of ways this classicist of St. John's could have learned of the Piers Plowman in the Weymouth library, most obviously by reading Timothy Thomas's remarks in Urry's Works of Geoffrey Chaucer or via a visit to Longleat. The questions of when, and in what precise circumstances, though, remain a mystery, as our turn to the shadow history of the books and manuscripts of the Augustan Piers Plowman will now show.

\section{The mysterious afterlives of the Taylor/Burrell volumes}

The absence of this major episode from histories of Langland scholarship already underscores the arbitrary and contingent nature of the archive. The story of these items shows the same for the archives as conventionally defined as well: as the repositories of the materials that provide the foundations of our discipline, and as historical accounts of those repositories. Marks of ownership, knowledge of eighteenth-century social networks, and items seemingly as trustworthy as the Bodleian Library's shelfmarks and Manly and Rickert's account of recorded manuscripts of Chaucer tell a confusing story that on the whole seems to indicate the fate of these volumes in the wake of Taylor and Burrell's project. Taylor's acquisition of the Spelman manuscript would be most easily explained as a gift to him by the young Thomas, knowing of his master's earlier interest in the book, as a gesture of gratitude. And, depressingly soon after the project ended, Taylor in turn would seem to have got rid of both of his annotated and interleaved Crowley and Rogers editions, selling them to Richard Rawlinson before that collector's death in 1755 and the incorporation of his collection into the Bodleian in the following year. The Rawlinson collection, as is well known, includes two important Piers Plowman manuscripts, now MSS poetry 38 and 137 , as well as at least one Rogers, Bodleian $4^{\circ}$ Rawlinson 275, which he in turn acquired, 
together with MS poetry 38, from the collection of Thomas Hearne. ${ }^{35}$ It would be easy to accept that he purchased three more volumes of Langland, even if the transaction occurred in the last years or even months of his life.

But this story, it turns out, is wrong on all but one count, with the seemingly unassailable indicators of the Burrell items' provenance both the more interesting and disturbing to any sense that the Langland archive is a well-defined entity in the modern era. Again, Richard Farmer's annotations to the Haverford Rogers point the way, his comment on the "much pains" Taylor took with Piers Plowman continuing: "his Collections are among Dr. Askew's M.S.S.," followed in a lighter ink by: "They were bought at his Auction by Mr Gough." Farmer himself made many purchases at the Askew auction, but, as he reports, the great antiquarian Richard Gough (I735-I809) was the major purchaser, picking up, among other lots, these three:

- I2, "Pierce Plowman's Vision, interleaved with MS. Notes, by Dr. Taylor, 4to — I56I";

- I3, "Another Copy, interleaved with MS. notes, 2 vol 4to I550";

- 319, "Dialogue of Pierce Plowman, \& several other Poems, Paper \& Vellum." ${ }^{36}$

Gough's purchase of the last of these, obviously the Spelman MS, for $\mathfrak{E 2}_{2.5}$.O is part of the received account of that item's provenance. ${ }^{37}$ But lot I2's shelfmark, combined with critics' general indifference to the printed editions, has prevented anyone from realizing that it is $4^{\circ}$ Rawlinson 274, the Rogers in which Taylor constructed the first modern account of the Langland archive. ${ }^{38}$ If the middle item, lot $\mathrm{I} 3$, did not exist, we might imagine that Taylor produced two such volumes; but that lot can only be $272 / 273$. Of the hundred-and-sixty-plus copies of Crowley's and Rogers's editions I have located, only Burrell's is interleaved and in two volumes. These items, which entered the Bodleian's collections over fifty years after Rawlinson's bequest, must thus be "Rawlinson 272-4" rather than now-lost replicas of them.

Given the working conditions in the Bodleian Library c.I8Io, it was perhaps inevitable that such a major cataloguing error as this, which obliterates the books' provenance, would occur. The Rawlinson accession was "completely overwhelming" to the very small and ill-paid staff of the Library, wrote William Dunn Macray, with "the full extent of Rawlinson's collections" ascertained only in the mid-nineteenth century, when it became clear that "cupboard after cupboard was found filled with MSS. 
and papers huddled together in confusion." ${ }^{39}$ In I809 the Gough bequest of printed books and manuscripts on Saxon and northern literature, for the use of the holder of the Rawlinson professorship, added to the mayhem. ${ }^{40}$ The situation became infamous. "Seriously speaking, I am quite vexed at Douce's disposition of his collections," Frederic Madden complained in I834 when that collector did not leave his manuscripts to the British Museum: "To leave them to the Bodleian is to throw them down a bottomless pit! They will there be neither catalogued, bound or preserved, but suffered to sleep on with the Gough Rawlinson \& Tanner collections undisturbed above once in a luster by some prying individual of antiquarian celebrity." ${ }^{41}$ The error must have occurred very soon after the Gough bequest, since no Piers Plowmans appear in the I8I4 catalogue of those items. ${ }^{42}$

Blame can be laid squarely at the feet of Philip Bliss, an assistant at the Bodleian, who was cataloguing both collections. A successor to his later post as keeper of the University Archives said that his thirty-one years in that post "introduced the greatest and most far-reaching disorder in the collection." ${ }^{43}$ But Bliss's reputation, like Urry's, should not be sullied before taking note of his own, previously unknown contribution to the textual scholarship of Piers Plowman, in which indeed Urry's influence is manifest. In the inaugural volume of British Bibliographer, Bliss printed "Specimens of the MSS. of Pierce Plowman preserved in the Bodleian," which he offered "in the hope that these collations may assist some future editor of the work, by pointing out what MSS. do exist and are worthy of inspection." ${ }^{44}$ The specimens are the opening ten to seventeen lines of the Prologue as they appear in seven manuscripts. His sole observation about the variants concerned their near unanimous reading of "soft" for Crowley's "set" in line I, but he brought something new to this hoary topic by noting Rawlinson poet. I37's unique b-verse variant "whenne I south wente." Bliss's comments are most noteworthy both for first suggesting that editors should collate manuscript readings and for his remark that Digby 145 "is composed of the two Editions, as Ritson terms the various copies he had collated," one of which, Harley 604I, was indeed an $\mathrm{A} / \mathrm{C}$ splice though Ritson did not notice as much. ${ }^{45}$ Such minute attention to variant readings in the service of a critical edition is exceptional before the days of Skeat. Neither Thomas Whitaker nor Thomas Wright, whose editions of Piers Plowman would be published in 1813 and 1842 respectively, engages in much collation, and neither Urry, Taylor, the young Burrell, nor Ritson shows any interest in editing the poem. 
At least Taylor is now absolved from the charge of caring so little about the poem's textual history that he unloaded his and his student's extensive record of that history even before Burrell had graduated from St. John's. And while the next known record of the Spelman MS at first glance seems to indict the third viscount on a similar charge, that, too, is the product of a slip by the archons. John Manly and Edith Rickert's account of recorded manuscripts of Chaucer, if accurate, would suggest that Thomas Thynne unloaded the Spelman MS in 175I and that only his tutor Dr. Taylor's devotion saved it from oblivion: "In a sales catalogue (T. Osborne, 25 March 175I) including books owned by Edward Webbe, counselor-at-law, Alexander Dacre [recte Davie] of Sidney Sussex College, Cambridge, Francis Carrington, Lady Mary Worsley, and others," say Manly and Rickert, is the following: "'4283. Piers Ploughman's Vision, Maundevyle, Storie of Susanne and Daniel, Joseph, Troylus in 5 books, Lucifer to all our dere felawes. Vellum and paper. Each article except the last has the autograph of Sir Henry Spelman.' 5 l. is s. 6 d." ${ }^{46}$ For a long time after I came upon this entry, I imagined, that is, fabricated a narrative according to which Weymouth sold this volume c.I75I, in keeping with his reputation as "an inconsiderable debauched young man," who would be "so ruined by gaming," in Horace Walpole's estimation, "that the moment before his exaltation" as Viceroy of Ireland in 1765 , "he was setting out for France to avoid his creditors." 47 Poor Dr. Taylor must have had his hands full in trying to educate this young man, whose character bore no resemblance to that of the assiduous Burrell. The most probable scenario, assuming the accuracy of Manly and Rickert's account, would be that Taylor stepped in to preserve his beloved Longleat manuscript, a heroic action that ultimately prevented its loss to history, portions of its text preserved only in the collations of his student Burrell and, on a much smaller scale unknown to Taylor or anyone else, Urry.

So I believed until finally it dawned on me that Manly and Rickert encountered lot " 4283 " not in that catalogue of $175 \mathrm{I}$ at all, but in the $18 \mathrm{IO}$ catalogue of the sale of the library of Richard Gough, who as we have seen had purchased it at the Askew sale. ${ }^{48}$ Manly and Rickert confess that they made only "a rapid search" of the British Museum's sale catalogues, which made it "easy to overlook even the most interesting item," 49 explaining how they lost track of the catalogue in which this entry in fact appeared. This Gough Piers Plowman/Troilus, unlike the others he purchased at the Askew sale of Taylor volumes, did not stray, even if the great Chicago editors' account led me to imagine something totally 
different. In this case the archive itself, as it were, turns out to have retained its stability, if to little effect given how wildly, and seductively, off-base its only modern account, itself by now part of that very archive, turned out to be.

\section{Manuscript of my own}

The more comforting notion that Thomas Thynne gifted the Spelman MS to his tutor, then, seems the most probable explanation of how it joined Dr. Taylor's collection. There it joined other Middle English works, perhaps including another Piers Plowman which is now either lost or unidentifiable. Taylor certainly owned BL Additional MS 34360, a miscellany featuring lots of Lydgate and Chaucer, which had belonged to John Stow. ${ }^{50}$ The evidence for the other item is to be found in his itemization of the "MSS Copyes of our Author" in the opening flyleaves of $4^{\circ}$ Rawlinson 274 . The list itself is invaluable as evidence both of the growing awareness of Piers Plowman's textual status in this era and, as with the Urry-Thomas list, of the provenance of certain copies. So far as I know, not until Ritson and Bliss some seventy or eighty years later were any such lists published. The bulk of items, fourteen manuscripts and two excerpts, are listed on fols. iii $^{\mathrm{v}}-\mathrm{iv}^{\mathrm{r}}{ }^{\mathrm{SI}}$. Taylor marks three of these with letters, "A" (CUL MS Dd.I.I7), "B" (CUL MS Ll.4.I4), and "D" (Cambridge, Corpus Christi College MS 293), marks that, so far as I can see, he employs only when noting that for Crowley's "set" in the poem's first line, ABCD read "soft," and in indicating that the glossary he transcribes in the back is from MS B. The sole entry on fol. iv ${ }^{v}$, on the top of the page, adds two to the tally: "Two MSS. Bibl. Reg. Cant. in Ff. \& Gg. The one upon Vellum \& of a good Age: The other upon Paper \& Recent," referring to 5.35 and $4.3 \mathrm{I}$ respectively.

Except perhaps for the earliness and thoroughness of the list, none of this is surprising. The situation gets more interesting on the next folio, after the seventeenth and eighteenth complete manuscripts on the list ("Cod. Coll. Gonv. Cantab.” [Gonville and Caius 20I/IO7]; "C.C.C. Oxon. library" [Corpus Christi College MS 20I]) and before mention of Joseph Ames's copy (now Oxford, Oriel College 79). Manuscript "C" finally shows up here, as "Bib. Pub. Cantab.," and would seem to be CUL Dd.3.13, the only item from that collection not mentioned so far. What, then, is the following item, in a lighter ink: "MS. belonging to the Univ. of Cambridge, found by me in the Registrar's Office"? It is not Additional 4325, acquired in 1905. It could be Dd.3.13 itself, but the 
absence of a demonstrative and use of the present participle (i.e., "MS. belonging" rather than "this manuscript belongs"), and the entry's status as a later addition, distinguish it from that item. So does its appearance in a sequence of items, just before the even more tantalizing "MS. of my own, bought at a Sale in London for EI.5.o," in lighter ink, which definitely does not describe an earlier manuscript.

Two more Piers Plowman mysteries, with no guiding descriptors. A. S. G. Edwards has shown that at least one manuscript of the Canterbury Tales that Urry consulted for his edition is now lost, but so far as I know no one has identified this possibility with regard to Piers Plowman. ${ }^{52}$ The situation is complicated by the fact that neither need be a Piers Plowman at all, since this is a list of manuscripts "of our author," that is, John Malvern, and Taylor includes about five non-Piers manuscripts on those grounds (e.g., BL MS Sloane 59, containing a treatise against pestilence by Malvern). The item "belonging to the University of Cambridge" is wholly elusive. If it is Langland's poem, and it is among those copies known to us now, then it must be an item whose provenance by this point is not established and that is no longer at Cambridge. ${ }^{53}$ Taylor must have purchased the other manuscript in London between 1730 and 1766, details that might yield to further investigation. Unless it left Taylor's possession during his lifetime, it ought to be among the items in the Askew sale at which Taylor's manuscripts and books were auctioned.

And indeed, among the unidentified items in the catalogue of the Askew sale is this, in the list of "Manuscripts, English, on Vellum": "328: Pierce Plowman, morocco, 4to." ${ }^{4}$ Whether or not this was Taylor's, this constitutes evidence for either the existence of another now-lost Piers Plowman or the provenance of an extant copy. Two manuscripts present themselves as possible candidates, if not very comfortably, not least because they lack Taylor's signature. In many ways Oriel College 79 seems perfect (vellum, red leather binding, quarto), but it is the next item in Taylor's list, where he identifies it as belonging to Joseph Ames; ${ }^{55}$ even less likely is the Ilchester MS, whose binding, while moroccan, might well be nineteenth century, and which was much more likely in the Ilchester family for time immemorial than purchased at auction by them in $1784 .{ }^{56}$

If Taylor's Piers Plowman is ever discovered, its provenance can be filled out as well. The annotation in the copy of Bibliotheca Askeviana that is BL shelfmark 679.e.26 reveals that its new owner was one "Lowes," who purchased sixteen items at that auction, including one other Middle English item, lot 313, the Canterbury Tales that is now BL MS Egerton 
2864 - the copy whose marginal annotations include pacientes vincunt. ${ }^{57}$ Here the trail ends, leaving behind new information either about one of the fifty-odd items that form the core of the Langland archive, or about an item never before known, that, if discovered, has the potential to change our sense of what that archive both is and represents.

\section{The missing Spelman Piers Plowman}

This chapter will end where it began, at the I709 Spelman auction at which Lord Weymouth sourced so much of his burgeoning library, including, perhaps most prominent for Middle English studies, what would become Huntington Library MS Hm II4. Yet such a judgment must be provisional, for this was not Spelman's only copy of Piers Plowman. While John Hardyng's description of item 30 of the folios in the December I709 auction is, as is typical, nearly useless as a means of identification "Volume of English Poetry, Very Old [Vellum]" - Humfrey Wanley's, as with the Spelman MS, is much fuller: "Piers Plowman, damaged \& scr. Impf." (BL MS Harley 7055, fol. 232 ${ }^{\mathrm{r}}$ ), where "scr." means "script," "written," and for other items is usually followed by a date. For the third time in the narrow parameters of a study of a single volume's provenance, some pressing questions regarding the identity of an affiliated item arise.

The criteria by which to identify this copy, if it is extant, are: vellum, "folio" (i.e., relatively large format), containing only Piers Plowman, "imperfect," and lacking a known provenance for the years leading up to 1709. If it also needs to bear the signature of Henry Spelman, the manuscript is certainly lost unless the imperfections affected the location of his inscription after it came into his hands. Of the extant archive, the best possibility is CUL MS Dd.3.13, which is clearly defective and not listed in Edward Bernard's I697 catalogue. ${ }^{58}$ Another possibility is Dublin, Trinity College MS 2I2 (D.4.I), since its history from the date of its production "is a blank for the next 300 years, when between 1688 and c.I745 it came to Trinity." 59 But this would necessitate Wanley's recognition that it breaks off mid-folio at $\mathrm{C} 22.87$, some three hundred lines early, to characterize it as imperfect. Another, more distant possibility is $\mathrm{BL}$ Additional MS 34779, if Wanley noticed its lack of the final forty-two lines and took the effort to describe it as "imperfect" as a result. All other manuscripts that might seem viable fall short on one or another account. ${ }^{60}$ If one of these was Spelman's, there are no indications of that provenance, quite in opposition to Huntington $\mathrm{Hm} \mathrm{II} 4$ and most of his other manuscripts. 


\section{Conclusion: the eighteenth-century archive, and ours}

Or the item, like the enormous labors of John Urry and William Burrell, and especially the pains of John Taylor, has vanished from modern critical consciousness, awaiting rediscovery and the chance to make its own unique impact on histories of the poem's production. Wherever it is or was, this manuscript and the other documents considered throughout this chapter bear witness to the facts that the eighteenth century was not a fallow period for Piers Plowman textual scholarship, and that our own, by contrast, has been more fallow than it might have been. The readers and scholars of Piers Plowman between the age of Crowley and that of Whitaker, Wright, and Skeat were neither uninterested in nor unaware of the wild textual variation manifested in the manuscripts, and the existence of printed editions in their libraries did not obscure the importance of the manuscripts.

The assumption otherwise is especially worthy of note and correction since this era is the one when so much of the history of our own discipline, that of Middle English scholarship, is inscribed. It seems simply not to have occurred to anyone that the material copies of the four editions produced by Crowley and Rogers in the mid-sixteenth century might provide the materials for the sort of narrative this chapter has presented. Or that early editors of Chaucer took note of what was going on in the Piers Plowman situation. Or that the auction catalogues might contain Piers Plowmans that have disappeared from view. Or that everyday decisions by the laborers in the bowels of places like the Bodleian could both lay the groundwork for modern editorial achievements and distort the record of the archive's history.

Once put forth, none of this should be very surprising, but all of it should suggest the need to look well beyond the parameters within which the Langland archive has on the whole confined itself. It seems unlikely that such archival vicissitudes are to be found only on the road trod by what is now Huntington Hm II4 and its owners, students, and offspring. It is everywhere. The arbitrary, contingent, and partial nature of the Langland archive as currently constituted becomes clear quickly upon any search. Not least in need of revision is the notion that Middle English studies kept a safe distance from the scandals of fabrication that bedeviled the Shakespeare industry in the decades following the pains of Dr. Taylor, and the fruits of that labor. 


\section{William Dupré, fabricateur: Piers Plowman in the age of forgery, c.I794-I802}

Fabricateur, s.m. a fabricator; a manufacturer. This word was only used to imply a forger, or a coiner, or a fabricator of counterfeit money; but now means one employed in lawful and allowed fabrications or works.

William Dupré, Lexicographia-Neologica Gallica

John Urry, John Taylor, and William Burrell might well have been passionate about Piers Plowman, but not because of any innate love of poetry. We would hardly expect as much from readers of their era. Such passion would wait for Romanticism, another movement that has seemed wholly separate from the creation of the Langland archive. And yet it is Will and the medieval inhabitants of Langland's world that the 20-year-old Robert Southey, future poet laureate and friend and brother-in-law of Coleridge, is talking about here: "never was individual placed in a situation more important - never did man experience more heart-rending scenes. they are past - the energies of my mind have been all exerted \& I look back with astonishment at what they have endured." In October 1794 Horace Walpole Bedford, younger brother of Southey's best friend Grosvenor Bedford, had gifted him a copy of Crowley's second 1550 edition, and Southey is here following up, on November I2: "in the tumult of emotion I have neglected to thank you for Piers Plowman - or if I did thank you, have forgotten it." " A later owner of this volume, the great bibliographer and Shakespearean W. W. Greg, explains on its flyleaf that "it was in Oct. I794 that his aunt, Miss Eliz. Tyler with whom he lived, turned him out of her house on account of his engagement to Edith Fricher" - sister of Coleridge's future wife - "whom he married the next year."

By this point it is no surprise to come upon a need to turn to the material archive, to such documents as this letter or Southey's copy of Crowley's Vision of Pierce Plowman, to make sense of individuals' careers or their larger-scale historical and literary contexts. Other stories, which take shape across the boundaries of such periods, are manifested in those old 
books themselves: Southey's copy had belonged to Bedford and any number of others over the previous 244 years, would later be Greg's, and now enjoys the company of the former Sion College manuscript in the collection of Toshi Takamiya, in Tokyo. Likewise the best introduction to a more extensive and fascinating picture of Piers Plowman in the Romantic age is via the world of antiquarian and classical scholarship that occupied Chapter 5, so foreign to the passion of Southey. It occurs in John Taylor's Rogers, now Bodleian $4^{\circ}$ Rawlinson 274, which brought with it the work of another John Taylor - in fact, signaled its association with an item whose own history would see it become among the most celebrated and controversial portraits in England, one at the heart of the late eighteenth century's self-definition as site of "authenticity" above all.

Responding to the signature of Robert Keck on the title page, Dr. Taylor inscribes, as would Greg, a mini-biography of this notable earlier owner into the copy: "From Mr. Rob. Kecke of ye Temple, who had ye Origin did Vertue copye his print of Shakespeare." The "Origin" is the painting that would become known as the Chandos portrait, inaugural accession of the National Portrait Gallery, reproduced on the covers of innumerable books. Keck attributed the painting to one John Taylor, but in his day, as the later Dr. Taylor of St. John's College reports, it served as the original from which George Vertue had recently made an engraving (see Figure I4). Whatever attraction the coincidence of names might have held for Taylor, the Shakespeare connection would have been difficult to look past. "The eighteenth century," as Samuel Schoenbaum remarks, "had a rage for Chandos."

By the end of the century, though, the situation had altered dramatically in ways that marked a decisive break between the respective eras of John Taylor and of Robert Southey. The Chandos portrait and its most prominent advocate, Edmond Malone, became embroiled in heated controversies over questions of authenticity and forgery, concepts, at least with regard to Shakespeare, that are themselves products of the Malone-Southey era. This is when the revolutions in France and America "brought a new order of subject into being," as Margreta de Grazia says, one that was "cut off from past dispensations and dependencies," among whose manifestations was the very discipline of literary studies as conceived by Malone himself. ${ }^{4}$ It was in this unsettled milieu, rife with revelations of scandalous forgery as with triumphant scholarship, that a remarkable and heretofore unread chapter in the history of Piers Plowman - that of its first modernization - was written. It is a story to which Southey will return in I802, as defender of the legitimacy of Thomas Chatterton (1752-70), also 


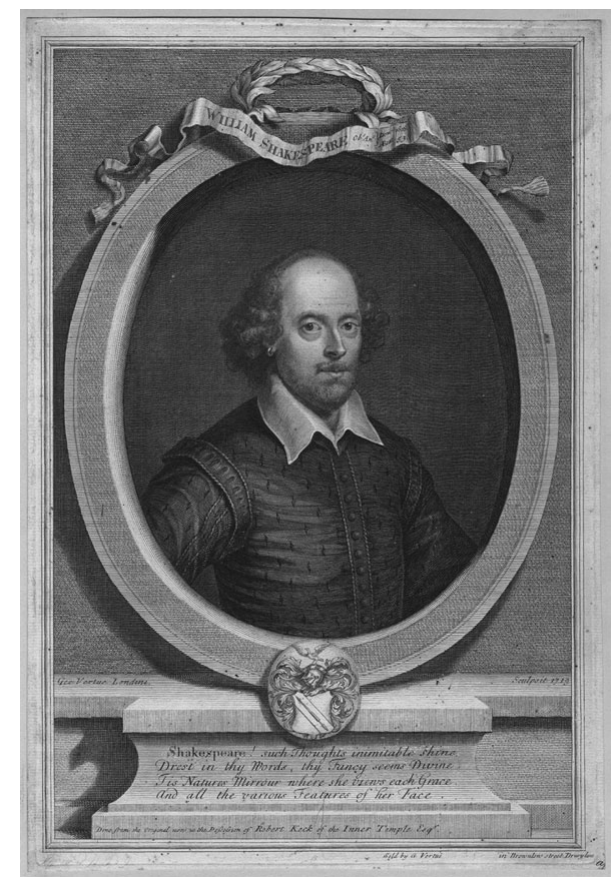

Figure I4 Vertue's engraving, taken from the Chandos portrait. London, National Portrait Gallery, NPG D25488

known as "Thomas Rowley," supposed medieval poet. In the meantime, the Chatterton/Rowley episode's role in a scandalous novel of 1780 had, over a decade later, inspired the young William-Henry Ireland to fabricate, in the term's most literal mode, Shakespearean documents, even a notorious play. The disappearance from modern critical consciousness of the fabrication of Langland by one William Dupré, distant disciple of Chatterton, is the primary, if implicit, topic of this chapter, one that necessitates a detailed rehearsal of these fascinating episodes, beginning with the arguments generated by the fall of the painting in Robert Keck's collection, the "Chandos portrait" of Shakespeare, when he also owned a Rogers Vision of Pierce Plowman.

\section{Edmond Malone and the authentic Shakespeare portrait}

"This is the portrait of Shakspeare, which has been so frequently engraved, and to which the fancy of each succeeding engraver has added every conceivable variety of feature, expression, and dress," wrote James Boaden 
in I824 of Chandos. "No picture within the last hundred years has been more frequently copied." All this variation induced Edmond Malone to seek out the original from Lord Chandos in 1783 , upon which he obtained permission to commission Ozias Humphry to draw it afresh, in crayon, from the original. ${ }^{6}$ Chandos had overtaken the Droeshout engraving, featured on the title page of the First Folio, as the image of choice for editions in Malone's century. But the rage for Chandos, perhaps inevitably, divided itself. In the early I79os a rival appeared on the scene, today called the Felton portrait, whose "close-up focus on the egg-shaped dome," says the cataloguer of the Folger's paintings, "makes him seem an inhabitant of an extraterrestrial dimension." George Steevens became its greatest champion, and unsurprisingly "employed the picture as a weapon with which to bash his rival Edmond Malone, who had done so much to support the claims of the Chandos Portrait as being from the life." 8 Another of Steevens's weapons was mockery of the Chandos portrait's pedigree by suggesting that "the possession of somewhat more animated than canvas, might have been included, though not specified, in a bargain with an actress of acknowledged gallantry," a mean reference to the story that Keck had purchased it, and more besides, from the great actress Mrs. Barry for 40 guineas.?

History has been kinder to Malone's candidate, still deemed "the most probable contender to be a portrait of Shakespeare made in his lifetime," than to Steevens's, now considered a fake, perhaps promulgated by that sly editor himself. ${ }^{\text {IO }}$ These claims and counterclaims regarding authenticity and forgery, intimately related to the issues with which editors like Malone and Steevens grappled in their work on the Shakespeare text, came to a head only a few years after the Felton portrait reached the public eye. Indeed, Boaden had said: "There is however something of a strange coincidence" in what was known about the provenance of the Felton portrait:

Mr. Wilson receives in 1792 from a man of fashion, who must not be named, a head of the poet, dated in I597, and endorsed Guil. Shakspeare. About the same time, were received sundry deeds, letters, and plays of Shakspeare from a gentleman, who in like manner was not to be named. And they abounded in the hand-writing of Elizabeth's reign, and also exhibited the poet's name with the recent orthography of the Commentators. I do not know that this picture might not have been intended to appear among the infinite possessions of the nameless gentlemen. ${ }^{\text {II }}$

Boaden is of course alluding to the notorious forgeries that a young man named William-Henry Ireland perpetrated in 1795 , his own father being 
the most immediate victim. The coincidence is indeed remarkable. It was Malone, in his Inquiry into the Authenticity of Certain Miscellaneous Papers ... (1796), who exposed the fraud in devastating fashion: ${ }^{\mathrm{I} 2}$ but one aspect of the aftermath was quite unexpected in a way that would have a direct, and unsettling, impact on the story told in this book. This was George Chalmers's Apology for the Believers in the Shakspeare-Papers of 1797, which responded to Malone's exposure of the scandal. Chalmers took umbrage not at Malone's conclusion, but at the assumption that, because the documents were forgeries, the faith of the believers was therefore fallacious. In sum, says Chalmers, Malone "might, with a good grace, have told the believers; 'I will admit the propriety, and the truth, of your positions; yet, will I demonstrate, that your belief is unfounded'": but "by conceding none of these points to the believers" he instead acted in bad faith. ${ }^{\mathrm{I3}}$

Early in this extraordinary diatribe, Chalmers catalogued the merits of the Felton portrait, which had failed to convince Malone despite his supposedly objective approach to evidence:

The oaken board, whereon the gentle Shakspeare is pourtrayed; the inscription of the poet's name, by a contemporary hand; the corresponding likeness between the original painting and the existing print of Droeshout; the corroborating evidence of Ben Jonson, who had compared "the figure" with the man; all concur to evince the genuineness of this ancient painting. Were we to consider the argument, without indulging prepossession, or referring to connoisseurs, the authenticity would be readily acknowledged by all judges of evidence, except by those, "who allow to possibilities the influence of facts."

Against this, Malone's devotion to Mr. Keck's dubious Chandos portrait comes across as bald hypocrisy, given his attacks on the "believers" for supposedly not following Cartesian logic: "Yet, Mr. Malone perseveres, in grappling to his heart, with hooks of steel, 'the unauthenticated purchase of Mr. Keck, from the dressing-room of a modern actress:' For, it is a part of his philosophy to allow the possibilities the influence of facts" (9)..$^{\text {I5 }}$ The ferocity of this rhetoric concerning a few brush-strokes demonstrates the ways in which what is included in the archive, so often an arbitrary process, can determine the overall shape of a discipline. For what have these portraits to do with Shakespeare's oeuvre? Nothing apparent. But no one would suspect as much from the passion with which Malone, Steevens, Chalmers, and innumerable others invest the question. That passion could not help but rub off on outsiders who could only wish to have their own voices heard, even if only to be scorned. 


\section{William Dupré and the Shakespeare forgeries}

Over the first half of 1802 readers of The Monthly Magazine were treated to what must have seemed a refreshing respite from all the unpleasantness of the previous decade: an entertaining and informative series of letters, which one William Dupré of Poland Street, Soho, translated from the French originals by Brunetto Latini, this time in the possession not of an unnamed gentleman but of Dupré himself. Most of these letters were addressed to Brunetto's fellow Italian poet Guido Cavalcanti, with a few to Charles, count of Anjou and Provence. They were composed during a visit to the court of Henry III of England, and tell about this foreign land's customs, literature, and scientific knowledge: the giraffe kept in the Tower of London, the poetry of a Cistercian monk, a conversation with Roger Bacon about the mariner's compass. Brunetto had his finger on the pulse of medieval England.

But it was too good to be true. In December, five months after the ninth and final letter, the magazine ruefully announced: "Mr. Dupré, the gentleman from whom we received the communications respecting Brunetto Latini, has thought proper, though not till after detection, to confess that he has been imposing upon us, and that, in the supposed letters of that person, he only meant to give a picture of English literature and manners, as they existed in that period, in imitation of the French Anacharsis": ${ }^{16}$ the reference is to Jean-Jacques Barthélemy's Voyage du Jeune Anacharsis en Grèce, first published in 1787 and quickly translated into English in many editions, which did the same for the ancient Greek era. Notwithstanding this correction, and Mario Esposito's publicization of the episode in a prominent scholarly journal in 1917, "Brunetto"'s account of his interview with Bacon, in particular, has often been cited as if it provided authentic historical evidence. ${ }^{17}$ In 1930 Esposito expanded on the account, noting that Duprés sources were manuscripts once in his possession that are now part of the Bodleian Library's Douce collection. ${ }^{18}$ Dupré must be counted as a major, and unheralded, manuscript collector of the his era. That, though, was all that anyone knew about the episode until Claudio Giunta's 2008 essay "Il triste destino di William Dupré, falsario," based on his discovery of a cache of letters from the I790s, which fill out the background. ${ }^{19}$

In I795, so Giunta revealed, Dupré wrote to his former supervisor in the army that he and his son wondered whether they might "flatter Ourselves that Our Service \& Sufferings will be attended to" by him: "I have had such good proofs of your humanity \& benevolence that I can hope 
everything from You, Sir." ${ }^{20}$ Two years later, writing from City Coffeehouse in Cheapside, he offered three manuscripts for sale to the earl of Liverpool: two on which he would rely heavily for his forgeries (now Douce 227, containing the laws of Oleron, dated I344, and Douce 319, a large folio volume containing Brunetto's Tresor), and an unidentified Italian manuscript called Trattato del Commercio. ${ }^{21}$ While it might seem odd to have targeted a mediocre politician better known today as father of a long-serving prime minister, Liverpool "was an excellent classical scholar," said the Quarterly Review in I8I5, "and possessed as great a variety of reading as perhaps any of his contemporaries (except only Burke)."22 And this doyen of the arts long employed George Chalmers, among whose (unofficial) duties was turning his pen against Thomas Paine, in the guise of a Francis Oldys, A.M., of the University of Pennsylvania, spelling his subject's name "Pain." ${ }^{23}$

Another letter in Dupré's hand, also of 1797 , reveals how he fell into such dire straits: during the "fatal Retreat of 1794" from French revolutionary forces, Dupré, in his capacity as director general of hospitals in the duke of York's army during its French campaign, "was mad Prisoner by the French with my Son, and a Young Man belonging to the Hospital, \& marched to Boisle duc, being stripped of a Sum of Money I had necessarily with me to bear our Expenses 'till we joined the Army." After three months' captivity they returned to England in I796, where he found himself "unhappily without employment," in which situation, "the only Hope remaining to me, is, that I may find some beneficent Character who may put me into Employment which may procure me Bread." ${ }^{24}$

The "beneficent character" to whom Dupré addressed this appeal was none other than Chalmers, in the very year that his Apology for the Believers in the Shakspeare-Papers appeared. The letter does not mention the Ireland forgeries, but there can be little doubt that Dupré intimately knew the case, and especially Chalmers's contributions. Everyone else did, after all, even those who did not seek his patronage and go on to perpetrate a mode of fakery that the Apology seems to value as highly as the real thing. The "believers," Chalmers writes, acknowledge the spuriosity of Ireland's forgeries,

yet; they do not admit Mr. Malone's principle, that our whole Archaology may be misrepresented, for the purpose of detecting a literary fraud; nor, do they allow, that the said republic ought to be invaded in its limits, or disturbed in its quiet, by his discharge of this inundation of mistempered humour, for the gratification of an indiscreet zeal. (iv) 
It might seem surprising that a public figure not only expressed no embarrassment at having been taken in by the fakes, but also championed the "quiet" of the "republic" of those believers over and above the rigorous philological sleuthing of Malone. Yet Chalmers does present the case on the basis of a certain logic: that "the believers, were led into their error, by system, while the inquirer himself is only right, by chance" (33); that his opponent is "right by chance, rather than convincing by argument" (I23), "wrong by system, and merely right by accident" (220), and so on.

The aspect of Chalmers's argument that, I suspect, emboldened Dupré five years later manifests itself in the peculiar combination of Malone-like logic with the rhetoric of belief and faith, which it is Chalmers's consolation to recognize as the foundation of the literary archive. The believers hold their hands on hearts in supporting the notion that the accused forger "comes into court with every presumption in his favour; with every probability of innocence, for his protection; with every inducement, under a want of proof, for his acquittal: But, the public accuser, by supposing what he ought to prove, ... raises a suspicion only, that the accused may possibly be guilty" (215). Chalmers's claim, in short, is that Malone is inhuman in his resistance to the riches of possibility, to faith itself: "The other concomitant of scepticism is hardness of heart" (23). The believers, Chalmers implies, embody the Pauline virtue of faith, where the skeptic shows his hard-heartedness: "Mr. Malone is induced by his scepticism to insist, that the prettye verses of Shakspeare never existed; because he has never seen them; and he is incited by a peculiar logic to argue, that whatsoever does not appear to him has never existed on earth" (39). By contrast, even though they ended up being wrong, the believers can take heart in the fact that "the profession of faith is strongly supported by external evidence" (219).

To Chalmers, it matters little whether the object of the believers' faith was factual: for it was true. Shakespeare did compose the sonnets for Elizabeth I even if the letters to that effect in Ireland's papers turned out to be fraudulent. Chalmers here defends the mode of scholarship, one as interested in the cultural capital of Shakespeare as in the facts of his life and career, that had held sway throughout the eighteenth century but that is now, under threat from Malone himself, collapsing. This is the subject of Margreta de Grazia's study of Malone's 1790 apparatus. ${ }^{25}$ Did Shakespeare speechify in his father's butcher shop while slaying a calf? Poach a deer from Sir Thomas Lucy, then post a satirical ballad on his gate as revenge for his punishment? Die of a fever contracted on a night of serious alcohol abuse with Drayton and Jonson? ${ }^{26}$ Editors before Malone did not concern 
themselves too much over the factual basis or otherwise of these stories, which served, rather, as evidence of Shakespeare's status as generator of narratives that were external to his own literary productions. Such tales were just part of the archive, part of the phenomenon to which the editions bore witness, not, as Malone later determined, extraneous falsehoods that impeded access to the authentic genius. Chalmers does not discuss any of those famous tales, but his approach to Ireland's papers is very much in keeping with his predecessors' to them: if the story seems plausible, it should get the benefit of the doubt rather than be subject to the antagonism of a hard-hearted skeptic.

In the Malonean mode of scholarship, the individual rises above the community, and from the present vantage point can pass over the vicissitudes of intervening history to gain direct access to the authentic original. De Grazia aligns this mode with the appearance of a new political subject arising from the revolutions in France and America in this era (see note 4). Insofar as the rise of "the subject" has long been taken as a marker of the early modern era's divide from its medieval past, it would not be pushing the case too far to say that with the American and French Revolutions and with Malone's I790 Shakespeare - modernity finally arrives. It does so, however, without George Chalmers's endorsement. (He first attracted Liverpool's attention via his authorship of pamphlets attacking Burke's conciliatory approach to the American colonies. ${ }^{27}$ Chalmers insistently celebrates the community of believers, who would rather, if put to the choice, have an openness of heart than a knowledge of fact; he would rather remain in the premodern world from which even such recent editions of Shakespeare as those by Rowe and Pope emanated.

This is the world that William Dupré, too, celebrates, more explicitly than does Chalmers, for he conjures thirteenth-century England, and does so from ancient manuscripts. We do not know how he came upon these items, and his attempt to sell them to Chalmers's patron obviously failed. But the very fact of his ownership, and the care with which he studied them, speak of a devotion to understanding premodernity rivaled perhaps only by that of antiquarians like Dr. John Taylor and Richard Gough. Dupré served in an army opposed to the French revolutionary forces, and his continual search for patronage, from Liverpool and Chalmers at the least, smacks of an acquiescence to, if not active desire for, a social position of fealty to his (Tory) superiors. Yet the primary motivation for the "Brunetto" letters was money: "It is hoped that every lover of ancient literature will contribute what assistance he is able towards restoring this restorer of good learning in the thirteenth century." The translator is in 
especial need of support because of the "difficulties, which an obscure man, who happens to be fond of letters (perhaps, too, engaged in literary pursuits, and it may be, moreover, in circumstances that are narrow and confined;) labours under from the want of a public-library in this great metropolis": a stark reminder that the material archive is a site of privilege. ${ }^{28}$ But if money and pity were the ultimate goals of the "Brunetto" letters, the imaginative use to which he put his manuscripts came from a different place, one whose path was lit by Chalmers's magisterial, and bizarre, backlash against Edmond Malone in 1797, which itself was only the most recent and immediate model for Duprés challenge to the dominance of the factual over modern historical consciousness.

\section{Love and Madness and Middle English}

In the March I802 Monthly Magazine, as Giunta observed, "Brunetto"'s second letter is immediately preceded by a note from that devotee of Piers Plowman with whom this chapter opened, Robert Southey, explaining the delay of the appearance of his edition of the Chatterton/Rowley poems. An insufficient number of subscribers had prevented publication, a gap whose closure would benefit both the world of letters and the memory of the lamented poet: "The merit of his works is now sufficiently known: hitherto they have been published only for the advantage of strangers and pilferers; they are now collected with the hope of rendering the age of his sister comfortable." ${ }^{29}$ That sister was Mary Newton; the pilferer, Herbert Croft, who stole Chatterton's correspondence from her and proceeded to publish it, together with Newton's desperate letter seeking the return of the correspondence, in his epistolary novel of 1780 , Love and Madness. ${ }^{30}$ The letter succeeded, the edition appearing the following January and netting Chatterton's sister, Mary Newton, over $£_{300} .^{31}$

Dupré was surely familiar with the story, and poetry, of Chatterton, by this point a Romantic hero, whether via the poetry itself or via the work that Southey cannot bring himself to mention, Croft's Love and Madness, the "very entertaining work" that would likewise have a profound effect on William-Henry Ireland. ${ }^{32}$ Love and Madness told the story of the notorious murder of Martha Ray ("R."), a popular singer and mistress of the earl of Sandwich, by a lovelorn vicar, James Hackman, "H." The latter is obsessed with forgers, and before eventually killing R., keeps writing her about them, with pride of place going to Chatterton, for whose sake, he asserts, "the English language should add another word to its Dictionary; and should not suffer the same term to signify a crime for which a man suffers 
the most ignominious punishment, and the deception of ascribing false antiquity of two or three centuries to compositions for which the author's name deserves to live forever." 33

Yet it is not just in its account of Chatterton, I would argue, that Love and Madness was so important to Dupré. For one, as Brian Goldberg has argued, "Croft was the type and form of the establishment writer: dependent on the patronage of the Church and the support of a gentlemanly readership, Croft perceived his interests as directly tied to the fate of the landed oligarchy." 34 Likewise Dupré, if "army" is substituted for "Church." Neither of these authors was a creature of the new professional writing class exemplified by Robert Southey, in the service of which Chatterton's death was seen to be something of a martyrdom. Also, two features of Love and Madness are directly pertinent to the "Brunetto" forgeries, and provide the context for Duprés work on Piers Plowman: the employment of the epistolary form for what was a fictional account of a historical event, which is what Dupré saw himself as presenting, even if the history was far distant and had little of a scandalous nature; and, more immediate, the presentation of primary documents within the letters of the novel.

Where Croft perniciously printed the manuscripts of Chatterton and his sister within a letter of " $\mathrm{H}$.," "Brunetto"'s letters introduced to modern readers two authentic Middle English works. The first and final letters between them provide the fourteenth-century debate-poem Ypotis, which "Brunetto" says is a translation into English of an Aesopian fable that he heard on the ship to England. ${ }^{35}$ The other is "a specimen of prose," The Abbey of the Holy Ghost, which he says he is sending because Guido had been "so well pleased with the English poetry which I sent you":

I now send you some extracts from a beautiful composition of a monk of great piety and learning. It contains the History of the Fall of Man and his Redemption through Christ, under the form of a well-contrived allegory. It begins thus, "Here is the Book that speketh of a Place that is called the Abbey of the Holy Gost the whiche schulde ben founded in clene concience." ${ }^{n 6}$

While it might be easy today to allow the scandal of the forgery and the centrality of matters Italian and scientific to dominate our assessment of the episode, Middle English literature is at the heart of these letters.

Duprés source for both these works was a manuscript in his possession, now Bodleian MS Douce 323, unmentioned in the letter to Liverpool five years earlier. It also contains an A version of Piers Plowman, a poem whose 
absence from "Brunetto"'s letters is surely the result of its relative canonicity, even in this era before Whitaker or Wright had published their editions. Readers of periodicals like The Gentleman's Magazine or The Monthly Magazine, not least Robert Southey, were too familiar with Langland's poem, both from the sixteenth-century print editions and from anthologies and literary histories such as those by Elizabeth Cooper (Muses Library, 1737), Thomas Warton (History of English Poetry, 1774-8I), and Joseph Ritson (English Anthology, I793-4; Bibliographia Poetica, I802), for it to pass as a previously unknown showcase of thirteenth-century English piety. ${ }^{37}$ What Dupré did instead is perhaps much more interesting, and should secure him a place as one of the liveliest figures in the annals of Langland scholarship.

Francis Douce adds this note to MS 323: "I purchased this Ms. of M. Dupré who had intended to publish a metrical version of Pierce Plowman modernized, of which I have preserved a specimen in this volume. The rest he would not part with" (fol. vir) - a tantalizing claim that leaves open the possibility that more remains to be discovered. That specimen now occupies a booklet comprising fols. $\mathrm{i}^{\mathrm{r}}-\mathrm{ii}^{\mathrm{v}}$ of the manuscript, after which their new owner repeats: "The above specimen by M. Dupré of whom I purchased the MS. F.D.” The attribution of this item to someone named Dupré appears in two nineteenth-century catalogues of manuscripts in the Bodleian collection, but without mention (or, probably, knowledge) of the Monthly Magazine scandal. ${ }^{38}$ So too the inverse: Thomas Wright publicized the translation in the introduction to his 1842 edition of Piers Plowman, but did not know its provenance:

An attempt at a modernization, or rather a translation, of Piers Ploughman, was made in the earlier years of the present century, but only a few specimens appear to have been executed. The following lines, which possess some merit (though not very literal or correct), are the modern version the author proposed to give of 1l. 2847-2870 of the poem. They were communicated to me by Sir Henry Ellis.

\footnotetext{
"Next AVARICE came; but how he look'd, to say, Words do I want that rightly shall portray:

Like leathern purse his shrivell'd cheeks did shew, Thick lipp'd, with two blear eyes and beetle brow: In a torn threadbare tabard was he clad, Which twelve whole winters now in wear he had; French scarlet 'twas, its colour well it kept, So smooth that louse upon its surface crept." ${ }^{39}$
} 
Only now, over 2IO years after the composition of this translation, can it finally be confirmed that these are all products of the same episode. ${ }^{40}$ The lines Wright printed as an anonymous oddity belong to William Dupré, who in turn is the forger known to Chalmers and, later, to the readers of The Monthly Magazine, and whose account of the mariner's compass would gull Thomas Wright himself (among many others) some decades down the road. ${ }^{4 \mathrm{I}}$

\section{William Duprés Piers Plowman}

The marks Dupré left on the Douce 323 Piers Plowman bear witness to an intelligent, if not too taxing, engagement with the poem. There is "much imagination" in Will's vision of the fair field of folk (fol. $\mathrm{IO}^{\mathrm{r}}$ ), he writes, and "striking Specimens of Allegorical Satire, with much Sense \& Observation of Life, \& some Strokes of Poetry" where Will asks the friars about Dowel at the beginning of A passus 9 (fol. 129 ), judgments for which he relies on Thomas Warton. While no William Burrell, Dupré does subpunct the phrase "hold men in good lyf" at the last line of folio $\mathrm{I}_{3} \mathrm{O}$ (A 9.87) so as to note, "halye men from hell. Edit. I550" in the margin below, and, next to A I0.50 (fol. $132^{\mathrm{r}}$ ), observes, "From hence for three folios to Thanne had wyt a wyf \&c [A II.I] seem not to be in the Edition printed in $1550 . "$

Plenty of others did this kind of thing, of course: what sets Dupré apart is the modernization. Modern scholars have not quite known what to make of this phenomenon. On the one hand, Vincent DiMarco excludes renderings of Piers Plowman into modern English from his Reference Guide "except when such works in their introductions or notes present critical commentary deemed worthy of admission": the labor that goes into the translation, and the product itself, do not suffice. ${ }^{42}$ On the other, such dismissiveness is perhaps more than balanced by the achievements of scholars as distinguished as George Kane, E. Talbot Donaldson, A. V. C. Schmidt, and George Economou, all of whom have either translated Piers Plowman or commented on the difficulties and importance of doing so since the appearance of DiMarco's collection. ${ }^{43}$ As the editors of the 1989 volume of The Yearbook of Langland Studies observe, modernizations are the products of "arguably the most demanding of all critical endeavors," especially with "a problematic work like Piers." 44 Moreover, translations "have significantly influenced critical perceptions of the poem" 45 - yet this applies to neither Duprés translation itself nor Wright's notice of it. The earliest known translation of 
Piers Plowman into modern English cited by modern bibliographies is Kate Warren's of 1895 , based on Skeat. ${ }^{46}$

Wright's comment on its own, some forty years after Douce's work on the poem, shows that the episode was not entirely unknown in its day, though the line of transmission from Dupré to Wright remains obscure. Douce worked closely with Wright's source, Henry Ellis, at the British Museum, where they collaborated on the catalogue of the Lansdowne collection. Wright's ignorance of the provenance or author suggests that he did not see the document sewn into Douce's copy. Ellis probably took a copy from it, then, and might well have shown others in addition to Wright. It also seems probable that Dupré approached publishing houses, even if he only ever completed the surviving specimens. He was no novice on that front, having in I8oI published Lexicographia-Neologica Gallica: The neological French dictionary; containing words of new creation, ... The Whole forming a Remembrancer of the French Revolution, which was in general well received, one of whose entries provides this chapter's epigraph. ${ }^{47}$

Dupré probably saw a serious gap in what was a thriving market of modernizations of Middle English poetry - one monopolized by Chaucer. The phenomenon began with Dryden and Pope and continued in the work of at least seventeen known and anonymous translators who, as Betsy Bowden has shown, "produced thirty-two modernized Canterbury tales during that century, plus tale links and adaptations of each other's work," some of which appeared in The Monthly Magazine. ${ }^{48}$ Because "reception data so precise and extensive" as that she presents in her collection "is available only for Chaucer among English authors," the existence of data regarding any other medieval poet is invaluable. ${ }^{49}$ The materials she collects provide one small instance regarding Piers Plowman that helps to explain why no modernizations of that work competed with the Canterbury ones.

This appears in "the most extraordinary rendering of Chaucer" of the Augustan era, the anonymous "Miller of Trompington, Being an Exercise upon Chaucer's Reeve's Tale," published in 1715. "It is true that the unknown author claims to have written it thirty years before," says Derek Brewer, "so we may be libelling the eighteenth century by attributing this version to it." " Brewer is exasperated by, among much else, the "long and totally irrelevant dialogue between Allen and John on the nature of translation," which of course has no parallel in Chaucer's own poem. ${ }^{51}$ When their subject turns to "the Clink and Blank of Poetry" (847), that is, rhymed versus unrhymed verse, Allen mocks the former sort for its associations with the materials discussed in Chapter 3: 
The Clink of Syllables call'd Rymes,

Brought in ith'barb'rous Runick times,

To sober Criticks seems to be

A paultry part of Poetry,

Becoming Monkish dull Divines,

Who traded much in Leonines, (848-53)

to which John rejoins:

Altho' to spoil I should be sorry,

An undergraduate Antiquary,

Yet I'll produce a line or two

Of Leonines in Cicero,

Before the Monks long time ago.

Calum mitescere; Arbores frondescere;

Vites latiscere, Pampinis pubescere;

Rami baccarum ubertate incurvescere. (854-6I)

Yet the ancients produced more than just this sort of empty rhyme: Allen, too, is able to call upon medieval precedent in responding to John's claim that "Blanks hence I prove are not the best, / They're not in use, tho' easiest" (883-4), for Milton's choice of form was not new:

Pierce Plowman th' oldest Poem is, And that's all Blank; a famous Piece. And from Tradition we have heard Our Isle shall boast a stone-blind Bard, Whose noble Fire and Stile sublime, And Numbers sweet without a Ryme, Shall give th' Angelick Hierarchy

Another Immortality, And shall regain to Paradise A sort of second Happiness. $\quad$ (885-94)

Dupré could not bring himself to be true to Piers Plowman's poetic example, perhaps because doing so would necessitate following the great stone-blind Bard's as well. And yet his choice of verse form, heroic couplets, is not as jarring as one might expect. The specimens of his modernization that survive, at least, are of passages whose content is much closer to Pope or even Benjamin Franklin than to Milton, as would have been the case had Dupré translated B passus i8. (Since he relied on Douce 323's A text rather than a Crowley or Rogers B text, that was not an option anyway.) Wright printed the opening few couplets of the first specimen, 5.IO7-45, the description of Coveteise in the confession of the sins episode, a Langlandian tour de force of social satire which has long been among the 
most popular of the poem..$^{22}$ Perhaps it lacks the sharp wit of The Rape of the Lock, but when rendered into heroic couplets it at least shows that Pope might well have dipped into the Langland portion of the Rogers he famously owned. ${ }^{53}$ And in the second passage, 7.237-61, where Piers and Hunger conspire to get the penitents back to work, Hunger turns into a veritable Poor Richard:

Neither eat thou till Appetite doth crave,

But to thy Meat a Sauce from Hunger have;

This Sauce, as it deserves, be sure to prize;

That thou may'st sup early from Dinner rise. (cf. 7.245-9)

The rhyming couplet form also shares some important characteristics with Langland's alliterative long line. Dupré's lines quite often have four main stresses and a marked caesura: "Next Avarice came; but how $\mathrm{He}$ look'd to say" (cf. 5.I07); "Rose, the Regrator, is the Name she bears" (cf. 5.I40); "Well know I, Hunger says, their Griefs to heal" (cf. 7.24I). Wright judged the performance "not very literal or correct," but he had a different poem - the B version - in front of him, and also had a vested interest in playing down achievements of the recent past. In any case, even where Dupré does seem to stray, it is difficult to blame, even to keep from praising, the results. Where his (mangled) copy read, "But yf a lous coude lepe I may it not trowe / he schulde wandre on pat walssh Scarlet so was it pred bare" (5.II2-I3; fol. II ${ }^{\mathrm{r}}$ ), the modernizer renders: "French Scarlet 'twas, its Colour well it kept; / So smooth that Louse upon its Surface crept." More often the translation is as faithful as possible given the different forms: "Put hem in a pressour \& pynned hem per Inne / Tyl ten 3erde or twelve telled prettene" (5.127-8; fol. II $\left.8^{\mathrm{r}}\right)$ becomes: "So well was stretch'd my Cloths, that e'en / Ten or twelve yards wou'd measure out Thirteen." What survives of the modernization, printed in the Appendix to this chapter, is faithful, engaging, and entertaining. Its failure to be published was a substantial loss to readers of the nineteenth century and today (see Figure I5).

\section{Aftermath: Margaret de Valois and the pilgrim of Douce I04}

How was Dupré found out? And how did these specimens of Piers Plowman end up in Francis Douce's hands? These questions share an answer. Douce's fame as antiquarian collector of ancient manuscripts has made his acquisition of these three manuscripts seem perfectly standard, and wholly unconnected to the Monthly Magazine shenanigans. But with 


\section{Alobtrier neat Art I employ'd \& Shength, \\ Toche my biath out to its whmost langlh: \\ Onfinest Webs Sexercis't om Shill,

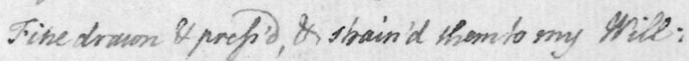 \\ Sowell was stretch d amy Gloths, that e'en \\ Ten or trelwe yards wrid mead we onch. Thirieen.}

Figure Is From Dupré's modernization of Piers Plowman. Oxford, Bodleian Library MS Douce 323, fol. $\mathrm{i}^{\mathrm{v}}$

collecting came an unmatched knowledge of medieval European and British literature and history, one far deeper than that attained by most of the gentlemen who read that periodical. This was Duprés undoing, as the inscriptions inside the back cover of MS 319 (Brunetto's Tresor) reveal: "Mr. Dupré presents his Compliments to Mr. Douse, and as he wished to possess the Manuscript of Brunetto Latini it is herewith left at his House at his Disposal. / No. 28, Poland Street. / Saturday, Oct. I802." This is followed by two more items, both in Douce's hand, inscribed at different times: "This was the person whose forgeries I detected in the Monthly Magazine," in ink, and "See Monthly Mag. for I802, p. 39I," in pencil. Now, we have already seen that of 323, the Middle English manuscript, Douce says "I purchased this Ms. of M. Dupré." In the final of the three, MS 227, Douce writes, "I had this MS from M. Dupré who has given an extract from it in the Monthly Magazine for I80I, p. 36" (Douce seems confused: the extracts are in the May 1802 volume, pp. 355-9), adding a brief description together with further bibliographical information about the "Roules d'Oleron" from which Dupré had quoted.

Both scholars who have discussed the episode have assumed that Douce purchased MSS 227 and 319, as he had 323, from their previous owner. ${ }^{54}$ But the entries by these successive owners of 319 point to different means by which that manuscript changed hands and also thus of the probable circumstances of the two sales. The fact of Dupré's inscription itself is telling, for unless the person with the pen is a famous author at a book signing, one does not usually inscribe an item sold to another, and indeed neither of the other two is so marked. Something odd also lies behind the claim that Douce "wished to possess" this 
manuscript. The most probable reason behind this desire is that, as Douce points out, he was the one to detect the forgeries that were inspired by it, upon which he must have confronted their perpetrator and extracted the primary source of the deception from its owner as a payment of sorts to the society of men of letters and as his own reward. Afterwards Douce took pity on the man, and did indeed purchase the other two manuscripts. The fact that all three were being used for the forgeries in 1802 identifies July of that year as the terminus a quo of their transmission to Douce.

Most Langlandians probably know "Douce" as the name of a manuscript (IO4, the illustrated one, rather than 323), and not as a historical figure who played an important role in creating the Piers Plowman archive, but it is clear that that role extended well beyond the mere collection of manuscripts and printed editions to pass on to the Bodleian. Without him the only thing we would know about the first modernization of the poem would be what Wright says. And like the figures who populated Chapter 5, he left his mark on the manuscript. To facilitate cross-referencing among his two manuscripts and the editions of Crowley and Whitaker, he transcribes the opening line of each passus on the frontleaves. He also comments on a few variants in the opening lines, such as the "soft/set" crux, and mentions another otherwise unknown episode in the eighteenth-century reception of Piers Plowman: "There was a transcript (collated) of a part of P. Plowman made by one Frederick Page from MSS in the B. Museum about the year 1797. His papers lay a long time in the reading room. Q. what became of them \& of Mr. Page himself who was known to my valuable \& excellent friend Mr Brown the traveller" (fol. vi ${ }^{\mathrm{r}}$ ). This Frederick Page is probably the writer on the poor laws (1769-1834), drawn by the poem's treatment of the indigent. ${ }^{55}$ ("Mr Brown the traveller" remains a mystery.) Whoever Page was, a portion of his transcription, taken from MS Cotton Vespasian B XVI, survives, even if not in any Langland scholarship to date, still in the collections of the institution where Douce saw them, now as BL Additional MS 6399A, fols. $29^{\mathrm{r}}-3 \mathrm{I}^{\mathrm{v}} .{ }^{56}$

Dupré did not slink into obscurity upon Douce's unmasking of the faker. Just over a year after it confessed to having been duped by the translator, The Monthly Magazine published the announcement that Mr. Dupré, compiler of the Lexicographia-Neologica Gallica,

is preparing for the press a Translation of the Memoirs of Margaret de Valois, first wife of Henry the Fourth of France, written by herself, and 
containing the Secret History of the Court of France for seventeen years, from 1565 to 1582 , including her Relation of the Massacre of the French Protestants in 1572, commonly styled the Massacre of St. Bartholomew's Day. These Memoirs will be illustrated with Historical Notes, drawn from Brantome and other writers, the whole forming a History of the Age and Times of Henry the Great, the wisest and best Monarch France ever knew. ${ }^{57}$

Claudio Giunta brought this notice to light, but could not find any trace of the promised book. ${ }^{58}$ In fact it would finally be published much later, in 1813 , under almost exactly the title here indicated, but saying only: "Translated from the Original French, with a Preface and Geographical Notes, by the Translator." 59 Perhaps the delay and lack of attribution were the effects of the scandal of 1802 . Whatever the case, this production is in keeping with the "Brunetto" letters, both in its epistolary form and in its purpose of illustrating "an Age." The Monthly Magazine's revelation of the forgery reported that Dupré "only meant to give a picture of English literature and manners, as they existed in that period, in imitation of the French Anacharsis." The modernization of Piers Plowman would have done the same, too, had it seen the light of day.

The authenticity of Margaret of Valois's letters is not in question, but even so the reviewer for The Monthly Review was cautious because "the French booksellers are very dextrous in manufacturing memoirs of persons of consequence." But other than alerting its readers that "the memoirs relate less to the general politics of the kingdom than to personal anecdote, in which respect they will gratify those who wish to view the interior of courts," the review finds everything perfectly acceptable. ${ }^{60}$ Thus does the Tory perpetrator of literary scandal find his way onto modern bibliographies in celebration of women writers. ${ }^{6 \mathrm{I}}$

For students of Piers Plowman there is another, even more obscure and haunting trace of Dupré's career, of which he was surely ignorant and which could not have made any sense to anyone but Francis Douce himself until now. It is found in MS 104, which Douce had purchased at the sale of John Jackson on April 28, I794, at least eight years before the Dupré manuscripts came into his possession. ${ }^{62}$ Yet the Dupré Piers Plowman had a material effect on the earlier, more famous acquisition, and in particular on what is certainly the most widely reproduced of its illustrations, that of the pilgrim on folio 
$33 \mathrm{~b}^{\mathrm{r}}{ }^{63}$ Shorn from context, the image seems perfectly suited to serving as a representation of the poem, which is about a dreamer's journey, as it were. But of course this is the fraudulent man, who says he has been to all the great shrines, but knows nothing of "St. Truth."

It is worth keeping the pilgrim's character in mind when analyzing the slip of paper, now fol. 33a, that has been inserted between fol. 32 and 33 b. On the recto, Douce transcribes the twelve-line poem, "Tutiuillus pe devyl of hell," that appears on fol. II2 ${ }^{\mathrm{v}}$, but on the verso is pasted a scrap of paper with two jottings for Douce's personal use, which are very difficult to decipher. The item in pencil, on the right, appears to read: "Pilgrim collate will / Both MSS \& add / to the Pilgrims story," though any rendering must be provisional: the prominence of a "Will" and of the "collar" of the drawing suggests some alternatives. Perhaps Douce is telling himself that he wants to collate this passage with the equivalent in his newer copy, MS 323. Yet the passage is very similar in the two texts so it is unclear why he would pick it as object of collation. The other item, in ink, seems to read: "See Illum? MS p. 33 / Ms Duprè fr. / where paper": Douce here tells himself to go to the illumination on p. 33, that of the pilgrim, where he has added the slip of paper; my best guess as to what I see as "fr." is that it is an abbreviation for "Frenchman" (see Figure 16).

In any case something about the portrait of the fraudulent pilgrim seemed different to Douce in light of his acquisition of the Dupré MS. The most obvious, if not secure, conclusion is that he saw in this image a representation of Dupré himself. Fraudulence is not the only thing that unites the two, though: so does a sense of poignancy, even dignity. The paperbacks that sport the image are not promoting Piers Plowman's satirical impulses; they are invoking its association with the simple, poor seeker. Likewise Douce allowed his relationship with the forger to reach more equitable grounds than it had when he strong-armed MS 323 away from Dupré: hence his purchase from him of two manuscripts, including the one containing Piers Plowman. There must have been something worth either pitying or respecting - more likely the latter, given what we now know of his substantial contributions to the world of letters - in this man. Whatever it was, there is no question that Douce was thinking of this forger, this first modernizer of Piers Plowman, when he turned back to his other copy. He could not get Dupré out of his mind. 


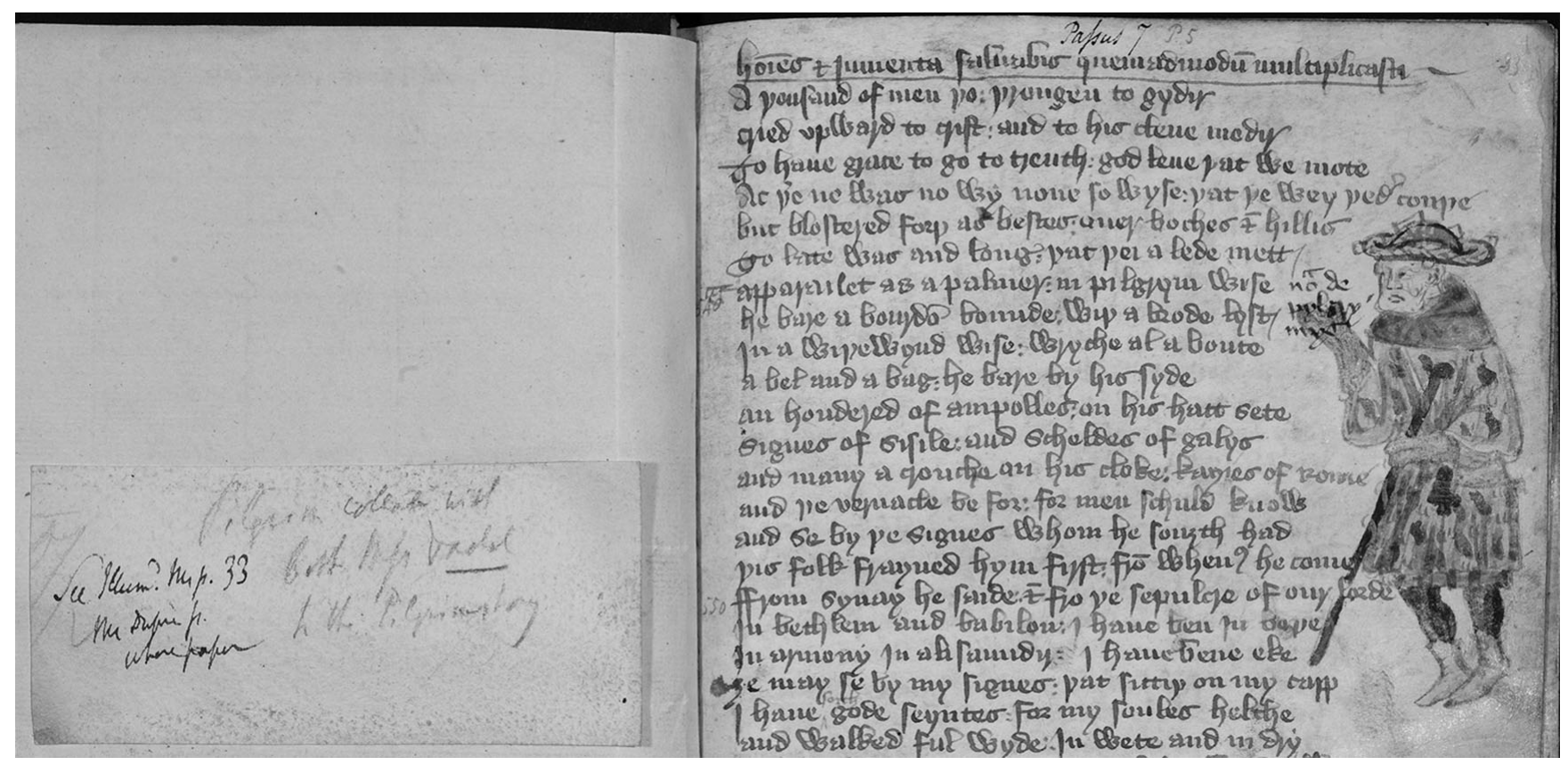

Figure 16 Douce's notes on Dupré and the pilgrim. Oxford, Bodleian Library MS Douce 104, opening at fols. $33 \mathrm{a}^{\mathrm{v}}-33 \mathrm{~b}^{\mathrm{r}}$ 


\section{Appendix: William Dupré's modernization of Piers Plowman}

Duprés modernization is quite polished and not in any need of emendation, punctuation, or the like. I have changed his underlining to italics, and omitted the catchwords at the bottom of each page. The first passage renders A 5.IO7-45, Covetousness's confession, from fol. II $8^{\mathrm{r}-\mathrm{v}}$ of the manuscript; the second, Hunger's advice to Piers at A 7.237-6I, from fols. $\mathrm{I} 25^{\mathrm{V}}-\mathrm{I} 26^{\mathrm{r}}$. At the bottom of $\mathrm{ii}^{\mathrm{V}}$ is Douce's comment "The above specimen by Mr. Dupré of whom I purchased this MS. F.D.”

\section{Pierce Plowman}

Rubrick, Hic venit Avaritia. Than come Covetyse \&c.

Next Avarice came; but how He look'd to say,

Words do I want that rightly shall pourtray:

Like Leathern Purse his shrivel'd Cheeks did shew,

Thick lip'd, with two blear'd Eyes \& Beetle Brow:

In a torn threadbare Tabard was he clad,

Which twelve whole Winters now in wear he had;

French Scarlet 'twas, its Colour well it kept;

So smooth that Louse upon its Surface crept.

Quoth he, My whole Life have I loved Gain,

And to serve Sin I whilom did obtain;

From Sin's grave Counsel Profit good had I,

He taught me how to cheat, $\&$ how to lie;

Well furnish'd with false weights I did repair,

With Goods to Winchester \& Wayhill Fair:

By dint of Guile my Wares I turn'd to Gold,

Which had not else in seven years been sold.

A Clothier next Art I employ'd \& Strength,

To eke my Cloth out to its utmost Length:

On finest Webs I exercis'd my Skill,

Fine drawn \& press'd, \& strain'd them to my Will:

So well was stretch'd my Cloths, that e'en

Ten or twelve yards wou'd measure out Thirteen.

My Wife a Windster was \& Cloth did make,

And to spin soft she to the Spinster spake;

The Pound she gave a Quarter more did weigh;

'Twas on our side, so I had nought to say.

Barley I bought my Wife now brew'd for Sale,

And well with Small Beer knew to dash her Ale.

Such Serving Men as cou'd for Lodging pay,

In my Bed Chamber by the Wool did lay; 
They all their Earnings spent in Ale, God wot, I made them for each Gallon pay a Groat.

My Wife was thirsty, \& full oft wou'd drink

Out of their Jug, 'twas gratis, you may think.

Rose, the Regrator, is the Name she bears,

A Huckster has she been Eleven Years.

Now Evil in good sooth I will eschew,

Nor cheat in weight, nor fraud ful Bargains do;

My Wife \& I at Walsingham* will pray,

And Bromeholme's Cross will clear our Sins away.

* Our Lady of Walsingham, \& Bromeholme Priory; both Places of great Sanctity in Norfolk.

Passus Septimus - Yet I pray thee quoth Piers \&c:

But say (Pierce cries) that useful Secret tell,

Which Sickness cures, \& keeps us sound \& well;

Often to me my Servants do complain,

And leave their Work undone thro' very Pain;

Well know I, Hunger says, their Griefs to heal;

'Tis when they've eat too plentiful a Meal.

Would'st thou be whole mark well these words of mine;

Do not taste drink ere thou begin'st to dine;

Neither eat thou till Appetite doth crave,

But to thy Meat a Sauce from Hunger have;

This Sauce, as it deserves, be sure to prize;

That thou may'st sup early from Dinner rise;

Let Surfeit at thy Table have no Seat,

He needeth a Variety of Meat:

These Rules observ'd thou wilt no Physic need,

For useless wou'd Physicians be, indeed;

And the Physician's costly Garb be sold,

His Hood of Fur, \& Gown with knops of Gold;

Thriving no more by Industry of Head,

He now must work with Hands to get his Bread:

The Leech's Potion is at best a Cheat,

And when the Patient dies we find out his Deceit.

Thy Words are wise (quoth Pierce) \& by St Paul,

They ought to be remember'd by us all. 


\section{Conclusion: Leland's madness and the tale of Piers Plowman}

We will always wonder what he may have burned. Henry VIII's assaults on the medieval past, especially via the dissolution of the monasteries, issue in this dilemma of the archive: its reliance on destruction. Hence what James Simpson has called "the melancholy of John Leland," a case study of mal d'archive matched by, indeed seeming to prefigure, that with which Joseph Ritson was afflicted 270 years later. ${ }^{I}$ In I533 Henry VIII commissioned Leland "to make a search after England's antiquaries, and peruse the libraries of all cathedrals, abbies, priories, colleges, \&c as also all places wherein records, writings, and secrets of antiquity were reposed." 2 The result of this was the De Viris Illustribus, a catalogue of important British writers including Chaucer and Gower, which, together with the work of his colleague John Bale, was among "the first attempts to shape a British, or even an English, tradition as an identifiable national tradition of letters," in Simpson's words. ${ }^{3}$ Yet Leland went mad in the process. As Simpson speculates, "the project of historical recuperation that Leland sets himself must of necessity have produced a divided consciousness, since Leland, in a 'highly schizophrenic' situation, is himself an agent of the destruction of the very past he seeks to recuperate."

This is the dilemma of the archivist writ large, and thus of literary scholars and historians, especially, given these historical roots of the English literary archive, of those who focus on Middle English, but can do so only from the vantage point of a moment that is so much the product of Henry's, and Leland's, acts of destruction. But such archive fever can be productive in ways that come to light only via our own, new negotiation of the archives. Simpson and others have expended much energy on the creation of eras now called "the Middle Ages" and "the Renaissance" via such projects as Leland's, a process played out more finely in the production of the very concept of "the Langland archive" as an entity wholly separate from the archives not just of Shakespeare (itself set apart from the Langland archive only on dubious grounds, as Chapter 6 
showed), but more so, and especially, of Chaucer. Langland's apologists are convinced that the separation of these two great poets in literary history, a process in which Leland seems so thoroughly implicated, has held sway until the modern critical era's recuperation of these two poets' "obligatory conjunction," now seen to be based on their status as contemporaries and possible neighbors who were responsible for some of the most important poetry of their era.

Previous generations, it is true enough, were much likelier to deem any attempt to compare these two poets "simply absurd." It is precisely the gap at the center of the Langland archive - that where someone identifiable as "Langland" would be - that fed such a conviction. As Robert Aris Willmott would observe in the early years of Victoria's reign, "the author of Pierce Plowman is a shadowy personage, whom it is impossible to bring clearly before our eyes; but Chaucer stands prominently forward in one of the most interesting epochs of our history." Chaucer, in sum, is not just upper-class, which might have been enough on its own to confirm his special status, but conjurable, both linguistically and historically:

Langland, with a vigorous mind and abundant powers of satire, spoke in the harshest language and with the most unmusical voice; Chaucer, with a fancy infinitely richer, and a vein of humour, more keen and brilliant, combined all the learning and accomplishments of the time. Instead of wandering among the Malvern Hills, he mingled in the pageantry of Edward's court, and cultivated his taste by foreign travel, and by intercourse, not only with the most distinguished persons of his age and country, but with the poets and scholars of the South.?

Such judgments, of course, are inescapably circular, as Chapter I consistently showed. Bodies of poetry are ascribed to each author on the basis of assumptions about what those ascriptions should be. As Kathleen Forni has remarked with regard to the Chaucerian apocrypha, "texts, and authors, do not enjoy aesthetic autonomy and their value is ultimately extraliterary and historically contingent." ${ }^{8}$ There is no "Chaucer" with a keen and brilliant humor apart from the texts assumed to be his on the grounds of their keen and brilliant humor. If, say, Piers Plowman had been ascribed to Chaucer, Willmott's characterization of the urbane poet would not have held up. Which is why Willmott would probably have rejected any such ascription: Piers Plowman does not display the infinitely rich fancy found in Chaucer.

My hypothetical proposal is itself not so fanciful as it might at first appear. For a longstanding tradition, beginning with Leland himself, had it that Chaucer did in fact write Piers Plowman. A few of the items I will 
survey here are known, but misdatings and other accidents of history have prevented a proper understanding of them; the others (like Willmott's judgments) are wholly new. Recognition of this tradition is important on a number of fronts, aside from its inherent interest to students of Chaucer's and Langland's reception histories: the establishment of the Chaucer canon in the sixteenth century, the work of the Harley cataloguer almost two hundred years later, and the tradition of amateur, and female, responses to the medieval are among the concepts and episodes here implicated. This conclusion turns attention away from the Langland archive, whatever its heuristic and inherent value as a category, and toward broader arenas, here represented by the murky ground occupied by both Langland and Chaucer. The power of concepts of authorship, and the richness of the early modern archive, will here serve as reminders of archives' tendency to undo themselves just as they lay bare their secrets.?

Leland's De Viris Illustribus includes a substantial chapter on Chaucer, whose catalogue of works begins thus:

Fabulae Cantianae viginti quattor, quarum duae soluta oratione scriptae

Sed Petri Aratoris fabula, quae communi doctorum consensu Chaucero, tanquam vero parenti, attribuitur, in utraque editione, quia malos sacerdotum mores vehementer increpavit, suppressa est.

Twenty-four Canterbury Tales, of which two are written in prose

The Tale of Piers Plowman, however, which is attributed by the common consent of scholars to Chaucer's authorship, has been suppressed in both editions because it vigorously attacked the bad morals of the clergy. ${ }^{\text {IO }}$

This item is universally taken to be a confused reference to the apocryphal Plowman's Tale. This assumption has both fueled and in turn been enabled by another assumption: that Leland wrote this in the mid-I540s, a few years after The Plowman's Tale was first ascribed to Chaucer, in William Thynne's 1542 edition.

Yet, as Alexandra Gillespie points out, the item "was apparently produced before the 1542 edition of The Workes that includes The Plowman's Tale (Leland uses a I532 edition of Chaucer to list his works), and Leland thinks of Langland's Plowman, Piers, not the unnamed pseudo-Chaucerian Plowman, as he writes up his bibliography." Gillespie's crucial point now receives confirmation in James Carley's edition of De Viris Illustribus, which shows that this item is part of what he terms "Stage I" of Leland's production, $c .1535-7$, rather than "Stage II," which began c.1542. ${ }^{12}$ This suggests that Thynne's inclusion of The Plowman's Tale in that edition might well be a sign of the influence of 
the De Viris Illustribus rather than the other way around. That influence might also be seen in Francis Thynne's claim, in 1598, that Cardinal Wolsey had prevented his father from including a "pilgrymes tale," presumably the Plowman's, in the I532 Works. ${ }^{13}$ There is great confusion here, not least in the fact that Wolsey was dead by 1532, and one of the likely explanations of the younger Thynne's claim, as Gillespie suggests, is that it developed from Leland's own account rather than referring to an event known to both of them. ${ }^{\text {I4 }}$

This redating of Leland's item raises serious questions about whether The Plowman's Tale is his referent at all, where "referent," it must be stressed, means a murky collection of cultural associations, not a welldefined and carefully interpreted work. For whichever poem was his referent, he did not know it well: The Plowman's Tale has no Piers; Piers Plowman is no fabula, no "Canterbury tale." On that criterion the two cancel each other out. But every other indication would favor Piers Plowman alone, bringing this work, in disguise, into the first account of the British literary archive. Whereas only a single copy of one edition of The Plowman's Tale securely datable before 1542 is extant, ${ }^{\mathrm{IS}}$ Piers Plowman was extant in numerous manuscripts, three of which, plus one excerpt, were themselves products of the first half of the sixteenth century. ${ }^{16}$ If by "Piers Plowman" Leland meant Piers Plowman, the absence of that poem's author from De Viris Illustribus is no longer a problem. No one would wonder about the absence of The Plowman's Tale. Finally, Leland would no longer be guilty of a glaring and extraordinarily uncharacteristic error of confusion.

It is difficult to dissociate these indications from their subsequent influence: The Plowman's Tale, perhaps as the result of Leland's confusion, soon made it into the Chaucer canon, after which this seemed his obvious referent. When Dryden, in his Preface to the Fables (I700), asserted that Chaucer "seems to have some little Byas towards the Opinions of Wickliff ... ; somewhat of which appears in the Tale of Piers Plowman," he was channeling Leland and certainly meant The Plowman's Tale. ${ }^{17}$ But, whether because others were confused by this important comment or because they referred independently to a tradition already known to Leland, the belief that Chaucer wrote Piers Plowman, and not the shorter Wycliffite poem, had taken hold. ${ }^{\mathrm{I}}$

\section{Stephan Batman (?) and the ploughman problem}

On August 22, 1577, a learned commentator inscribed his copy of Owen Rogers's 1561 edition of The Vision of Pierce Plowman and Pierce the 
Ploughman's Crede with a treatment of this ploughman problem. Simon Horobin has convincingly proposed that this was probably Stephan Batman, noted collector of medieval manuscripts and chaplain to Archbishop Parker, who owned and inscribed two manuscripts of Piers Plowman. ${ }^{\text {I9 }}$ The inscription opens with John Bale's Latin attribution of the "Visionem petri Aratoris" to Robert Langland and description of the poet as a disciple of Wyclif (item I in a list) together with additional thoughts on authorship:

2. Mention is made of Peerce Plowghman's Creede, in Chawcers tale off the Plowman.

3. I deeme Chawcer to be the author. I thinke hit not to be on and the same pat made both: for that the reader shall fynde divers maner of Englishinge on sentence; as namelie, Quid consyderas festucam in oculo fratris tui, trabem autem in oculo tuo etc.

4. And speciallie, for pat I fynde Water Brute named in this Creede: who was manye yeeres after pe author off pat Vision. ${ }^{20}$

The Plowman's Tale is here unquestionably Chaucer's, as is the Crede, of which this annotator "deems Chaucer to be the author" because of its lines "Of Freres I have tolde before / In a makynge of a Crede." ${ }^{2 I}$ But the author of "pat Vision" is not "on and the same" as Chaucer, a claim made on the grounds of dating and, it seems, the prominence of Latin therein but not in the Crede. Given how conclusive this commentator takes the evidence against Piers Plowman's ascription to Chaucer to be, one wonders why he mentions the possibility at all. The belief must have been prominent enough, whether only in Leland's account or in the literary circles of his day, to merit rebuttal. If not for that belief, however it was manifested, this note would not exist, in this form at least.

\section{Elizabeth Johnson and her Chaucerian copy of Piers Plowman}

The title page of the copy of the $\mathrm{Cr}^{\mathrm{I}}$ that is now CUL Syn. 7.55.I2, signed "Ez. Johnson" in a seventeenth- or eighteenth-century hand, is explicit about the phenomenon Batman takes for granted: "The Vision of Pierss Plowman sd to be wrote by Chaucer some say by a Wickliffian about Rc 2 d time." It seems very unlikely that Johnson is aware of the scholarly debates over the authorship of Piers Plowman that had occupied scholars since Leland's time at least. Had she been, she would have mentioned not Chaucer, but one or both of the candidates discussed by every other such annotator: "Robert Langland," as proposed by John Bale and Robert Crowley, and "John Malvern," John Stow's ascription, endorsed by 
Dr. John Taylor, ${ }^{22}$ figures whose respective merits made for a frequent item for discussion on the blank spaces of the manuscripts and early printed books. ${ }^{23}$

Johnson was the last in a long line of owners to have marked this copy. This is the one I mentioned in the Introduction, in which a sixteenth-century hand added a comprehensive alphabetical index to the poem's topics and made a number of changes to the text and its punctuation. But if she attended carefully to any of the earlier annotations, the likeliest candidate was this, on the back of the page on which she wrote her comment, in another sixteenth-century hand: "An abell reader, a good sentence dothe ofte spill. / quod Chaucer," a digest of a couplet from The Romaunt of the Rose: "For a reder that poyntith ille / A good sentence may ofte spille." ${ }^{24}$ It is not widely enough recognized that copies of Langland lived the same sorts of lives as did those more thoroughly studied copies of Chaucer. For Johnson's edition bears a particularly striking resemblance to a Stow edition of Chaucer in the same collection, CUL Syn. 2.56.2, which, says Seth Lerer, "is littered with a range of marginalia, apparently spanning many years and many hands throughout the seventeenth and probably the eighteenth centuries." In this book, too, someone has added Chaucerian lines, from Pandarus's speech in Book I of Troilus and Criseyde, which like the couplet from the Romaunt in Johnson's copy is "rearranged and slightly mistranscribed" and "carries the flavour of the maximal, or aphoristic.

This tendency to excerpt Chaucerian aphoristic verse offers a more plausible, if still unlikely, explanation for Johnson's attribution of Piers Plowman to Chaucer than does the scholarly discussion of Robert Langland and John Malvern, for it is just possible that she took the "quod Chaucer" to apply to the whole of the poem in her hands. But the simplest explanation is that she is merely reporting what she has picked up from Dryden or a similar source. Whatever the case, in her amateur approach Elizabeth Johnson had a kindred spirit, a century or so later, in the person of one Sarah King, who likewise saw an intimate connection between Piers Plowman and Chaucer, as recorded in the endpaper of her copy of Rogers's edition, now held in the London Library: "Chaucer lived in 1380 in Richard 2nd time, He often makes mention of Lydagate a monk of Bury and of his good Friend Piers the Plowman Chaucer."

\section{Humfrey Wanley and the birth of "William Langland"}

In the early eighteenth century the attribution of Piers Plowman to Chaucer finally entered the mainstream of scholarly discussion in the form 
of Humfrey Wanley's catalogue of the Harleian manuscripts. First is this description, of MS 875, MS H in William Burrell's collation, which contains:

That well-known Old English Poem, call'd Piers Plow-man. Imperf.

One of the Printed Editions ascribe it to Robert Longland: and from one of the MS. Copies, some have believed the Author to be one John Malverne: but Leland pag. 423. says, 'twas the Unanimous Tradition or Opinion of the Learned in his Time, that Geffrey Chaucer was the Author of it; which to me seems the most probable, for several Reasons. ${ }^{26}$

Leland's remarks had just, finally, been published in 1709, and Wanley's understanding of them seemed to him preferable to the two more widely endorsed candidates, Malvern and Robert Langland. Other oddities aside, we might wonder how anyone so well versed in the options could have imagined something so long as Piers Plowman, especially if the A version is assumed to be merely "imperfect," as a sometime member of the Canterbury Tales. Wanley's description of the next Piers Plowman copy in the Harley collection, MS 2376, explains:

At the End, is this Note, Hic explicit Visio Willelmi de Petro Plowman. Now among the several persons to whom the Poems of Piers Plowman have been ascribed, I remember not any William; so that if Geffrey Chaucer was the man, he disguised his name for fear of the Clergy, who are bitterly inveighed against in these Poems. And to shew that the preceding Note, and another that will soon follow are of some moment, I produce these Verses, extant in fol. 7.b.

A louely Lady of lore, in Lynnen y cloped, Com a-don fro pat Castel, \& cleped me by Name, And sayd William, slepes' pu? seyst pu pys Peple, \&c. ${ }^{27}$

"The Poems of Piers Plowman," plural: Wanley takes this to be a collection of separate items, which his listing of the manuscript's contents shows to be the Visio, the first item of the manuscript and what he is here discussing, and the three Dos, items two through four. The "preceding Note" is that to MS 875; the promised "other note" that will "soon follow" would certainly have appeared in the description of MS 3954 had Wanley lived long enough. ${ }^{28}$ This description of MS 2376 has received some modern notice, but only in a very confused way. Caroline Spurgeon includes the item in Five Hundred Years of Chaucer Criticism and Allusion, but as an anonymous item under the year I808, since she was relying on a reprint of the catalogue, which had been published in $1759 .{ }^{29}$ Yet the item was composed much earlier than even that date: Wanley inscribed "I3 August, A.D. I724" on the top of fol. $\mathrm{I}^{\mathrm{r}}$ of 
MS 2376, an image of which is now on the British Library's webpage, and he died in $1726 .{ }^{30}$

Yet Wanley's description of MS 2376 deserves wide recognition, not just as the clearest expression of the tradition outlined here, but, more important, for its role in the development of medieval literary scholarship. For it enabled, if somewhat perversely, the triumph of "William Langland" as the name by which we now call the author of Piers Plowman, having served as model for the first and perhaps most influential modern endorsement of "William" rather than "Robert" Langland as author of Piers Plowman, by Thomas Tyrwhitt, in his 1775 edition of The Canterbury Tales. Tyrwhitt adduces a nearly identical rubric, manuscript authority, and these same three lines to go in the opposite direction from Wanley, whom he has the grace to cite, at least, if not by name:

The Visions of (i.e., concerning) Pierce Ploughman are generally ascribed to one Robert Langland; but the best Mss. that I have seen, make the Christian name of the author William, without mentioning his surname. So in Ms. Cotton, Vesp. B. xvi, at the end of p. I is this rubric. "Hic incipit secundus passus de visione Willelmi de Petro Plouhman." And in ver. 5 of p. 2, instead of, "And sayde; sonne, slepest thou?" The Ms. has, "And sayde; Wille, slepest thou?" See also the account of Ms. Harl. 2376 in the Harleian Catalogue. ${ }^{3 \mathrm{I}}$

Tyrwhitt's citation of Cotton Vespasian B XVI, rather than Harley 2376, rescues him from suspicion that he is here merely plagiarizing Wanley in citing the identical lines. ${ }^{32}$ As it happens, his copy of Crowley's first edition, now BL C.7I.c.29, is carefully collated against the Cotton manuscript through sig. A.iir ${ }^{\mathrm{r}}$, the equivalent to the location of the Cotton manuscript's rubric cited above. Still, Wanley deserves fuller credit than he has received, or than Tyrwhitt is willing to acknowledge, as the inspiration behind the centrality of "Wille, slepest thou?" in the discussions of authorship: a nom de plume for Chaucer, in Wanley's odd account, and the Christian name of the poet, in Tyrwhitt's.

\section{Joseph Ritson, impersonator of Chaucer?}

Chaucer is thus the silent presence at the christening of "William Langland" as author of Piers Plowman. He maintains his power even where this new ascription is rejected, again in ways whose recognition has been prevented by modern criticism's ignorance of Wanley's role in eighteenth-century letters. For the descriptions of MSS 875 and 2376 were well known among the gentleman scholars of the later eighteenth century, both on their own merits 
and via Tyrwhitt's reference to 2376. Richard Farmer copied the description of Harley 875 into the end flyleaves of his copy of Rogers, identifying its author as Wanley, and points as well to the description of MS 2376.

Likewise, in the entry for "LANGELANDE ROBERT" in his 1802 Bibliographia Poetica, Joseph Ritson, seen in the Introduction inscribing his own $\mathrm{Cr}^{\mathrm{I}}$, says that Tyrwhitt's proposal that the author's name was "Wille" is counterbalanced by the evidence that the protagonist is, "as there is some reason to believe, no more than a personification of the mental faculty," for which he, like Wanley and Tyrwhitt, cites three lines, this time B 8.I27-9, as supporting evidence ("Here is WYL wolde witte, if Witte coude teche hym"). ${ }^{33}$ Here Ritson just mentions Tyrwhitt's passage; in his annotated Crowley, Ritson again says that "Will" is intended for the author's "allegorical appellation," followed by an inscription of B 8.127-9and quotes Tyrwhitt's entire paragraph on "William Langland"'s claim to authorship, and very accurately, down to the reproduction of his italics (via underlining), and with full referencing of Wanley's catalogue. ${ }^{34}$

One even wonders whether readers of Ritson's published materials took his vociferous denial of the attribution of Piers Plowman to the usual suspects as an implicit endorsement of Wanley's candidate. "This writer is still anonymous," Ritson wrote around I790; "there is no reason to believe that it was either Robert Langland, or John Malverne, but on the contrary a substantial one that it was not." ${ }^{35}$ Later students of Piers Plowman's authorship, like Richard Farmer and John Mitford, knew this claim well. ${ }^{36}$ In the Bibliographia Poetica Ritson goes still further: Crowley's and Bale's attribution of the poem to someone of the name of Langland, a Shropshire man, holds little weight since "there is every reason to conclude that he was a Londoner, by residence, at least, if not by birth"; the "John Malverne" proposal is "manifestly erroneous"; the poet seems to be a Londoner. ${ }^{37}$

Ritson having provoked such attention to his wholly negative speculations but offering no candidate of his own, it would have been reasonable, perhaps inevitable, for his readers to wonder whether he himself was disguising his beliefs for fear of retribution from pusillanimous critics, in effect modeling his career on that of Chaucer, who, as Wanley had said, disguised his name for fear of the Clergy. The single episode with which Ritson colors his account of Chaucer's life draws attention to, even while seeming to deny, the possibility:

Mr. Ellis presumes that he was entered at the Inner-temple, "because the records of that court [inn] are said to state, that he was fined two shillings for beating a Franciscan friar in Fleet-street:" a hum of Thomas Chatterton. 
See his Miscellanies, p. I37. He says that Chaucer haveing "distributed copies of the tale of Piers Plowman [which it is wel known he did not write]," the "friar wrote a satyric mummery upon him." ${ }^{8}$

The italics point to Piers Plowman as the referent, rather than the Plowman's Tale. The phrase "wel known" in this context would be ironic, since all that was really well known to most readers was that Langland wrote Piers Plowman, and that therefore Chaucer did not, a belief that Ritson himself demolishes a few pages later. The targeting of Chaucer via a satiric mummery, too, was re-enacted in Ritson's own career. This anonymous item of 1783 exploits a perceived tension between his vegetarian proclivities and scholarly blood-thirst:

The Pythagorean Critick

By wise Pythagoras taught, young R—s—n's Meals

With bloody Viands never are defil'd;

For Quadruped, for Bird, for Fish he feels;

His Board ne'er smoaks with roast Meat, or with boil'd.

In this one Instance pious, mild, and tame,

He's surely in another a great Sinner,

For Man, cries R—s—n, Man's alone my Game!

On him I make a most delicious Dinner!

To Ven'son and to Partridge I've no Goút;

For W—rt—n Tom such Dainties I resign:

Give me plump St- $-\mathrm{v}-\mathrm{ns}$, and large J-hns-n too,

And take your Turkey and your savoury Chine. ${ }^{39}$

Finally, the version of the legend Ritson cites, that by William-Henry Ireland's hero Thomas Chatterton, "even expands Speght's account of the physical assault," Sarah Kelen points out: "Chaucer now is said to have beaten his rival 'with his Dagger."' 40 Francis Douce claimed that Ritson, too, was always armed with a dagger. ${ }^{4 \mathrm{I}}$

Richard Farmer's or John Mitford's response to Ritson's negative comments on the authorship of Piers Plowman will always remain elusive, but neither could know that, in the privacy of his unpublished notebook, at least, where he also scorns the "dull performance" of the poem, Ritson in fact did not endorse Wanley's belief.

The author of this poem ... is altogether unknown. It is commonly ascribed to Robert Langland a secular priest in Shropshire; and some have most erroneously thought it the work of Chaucer. But whoever the writer was, it seems pretty clear that his name was William, by the vulgar contraction of which he is (in some copies, at least) often saluted in the course of the poem. (BL Additional MS I0285, fol. 247) 
Where on nearly every other issue of the day Ritson had passionate commitments, on this one his passion was only negative: the author was not William Langland, Robert Langland, or Geoffrey Chaucer. Ritson could do no better than ascribe Piers Plowman to "William," and that not even in the light of print. In any case, this comment unequivocally testifies to the currency of a belief in Chaucer's authorship that has become wholly obscure to us today. Wanley certainly lies behind this, and might well have been the sole intended referent of Ritson's "some" who have thus erred.

\section{The early print archive}

A belief to which only a single adherent put his name in public can hardly be claimed to have achieved any dominance. Yet the very existence of a tradition that attributes Piers Plowman to Chaucer suggests that perhaps we should not accept the dominant approach of earlier eras, in which any such conjunction is "absurd," at face value. Such claims protest too much, as if Chaucer's reputation needed protection from the unmusical poem with which his name had been associated in some circles. Likewise, John Bowers's notion that, despite their original mutual commitment to radical religious politics, Chaucer came to be seen as the safer, Lancastrian- and Catholic-friendly poet as opposed to Langland's blatant antagonism might be a bit too neat to hold up without important qualification. ${ }^{42}$ Wanley pre-empted Bowers in suggesting that Chaucer had to hide his identity because of Piers Plowman's anticlericalism; but in doing so Wanley shows that the two identities converged not only in the fourteenth century and in 1550 , as Bowers suggests, but also in 1724 and perhaps periodically throughout history.

The tradition given voice by Johnson, Wanley, and Ritson has surely remained so obscure in part simply because the differences between Chaucer and Langland, that is, between the archives that constitute these figures today, have seemed so pronounced. It probably never occurred to anyone to look for it. But another reason is that some of the most relevant materials have remained almost entirely absent from histories of reception. Research into this topic has long focused upon a relatively narrow body of materials: the prefatory material found in editions and translations, such as those of Crowley, Dryden, or Tyrwhitt; literary histories such as those by Ritson and his enemy Thomas Warton; and essays in outlets favored by antiquarians, like The Gentleman's Magazine and Notes \& Queries. Yet manuscript catalogues, scholars' notebooks, and the material books 
themselves - here, especially the Crowley and Rogers copies - are valuable yet on the whole untapped resources. William H. Sherman marvels at "the sheer volume of notes produced by early readers" of printed books, and "by the variety of techniques, habits, and interests they document": "These notes represent a vast archive of information about the lives of books and their place in the lives of their readers that we have only begun to explore." ${ }^{43}$ If this cursory survey of the Langland archive reveals a tradition that alters our perspectives on so many things, one wonders what a deeper exploration of the printed Chaucer archive, which is so much vaster and richer, would bring to light.

And that is one of the two main points that I hope readers will take away from The Myth of Piers Plowman: that, whether what is revealed is the possible Langlandian authorship of William of Palerne, or the nonLanglandian authorship of some of Piers Plowman's Latin, or the pains of Dr. John Taylor, or the fabrications of Mr. William Dupré, a rigorous analysis of what does survive in our material archives, from Melbourne to Bethlehem to the Bodleian, will reap benefits far and away beyond the effort it takes to track them down. The other main point is not less important, if not as exciting either: that we cannot help but fabricate the archive that we then interpret, and thus, armed with that knowledge, should tread carefully and lightly, doing what we can to limit the ill effects of our own archive fever on the archives or ourselves. It is often said that "the history of Middle English literary studies as a scholarly discipline has hardly begun": ${ }^{44}$ while this is becoming less and less the case, the statement still carries more force than one hopes it will in the next generation, and the place to look as we begin that history is not in the online archives so beloved by today's academics (including me), such as the journal databases Project Muse or JSTOR, or even the Early English Books Online database, but the archive of extant books and manuscripts and one could do no better than begin with the Langland archive, uncovering the ways in which Piers Plowman and its peers are the products of their authors' desires before moving on to the untold riches awaiting future generations. 


\section{Notes}

\section{Introduction}

I Jacques Derrida, Archive Fever: A Freudian Impression, trans. Eric Prenowitz (Chicago: University of Chicago Press, I996), IOI.

2 Ibid., 2.

3 David Greetham, “Who's In, Who's Out': The Cultural Poetics of Archival Exclusion," Studies in the Literary Imagination 32 (1999): 3.

4 Michel Foucault, "What Is an Author?" in Language, Counter-Memory, Practice: Selected Essays and Interviews by Michel Foucault, ed. Donald F. Bouchard, trans. Donald F. Bouchard and Sherry Simon (Ithaca, N.Y.: Cornell University Press, I977), II8-I9.

5 As observed by Greetham, "Archival Exclusion," 23 n.Io; see also Ralph Hanna, Pursuing History: Middle English Manuscripts and Their Texts (Stanford: Stanford University Press, 1996), 73, noting the "superfluity of authority" in the modern archives around which so many debates about editorial theory revolve.

6 Chaucer Life-Records, ed. Martin M. Crow and Clair C. Olson from materials compiled by John M. Manly and Edith Rickert, with the assistance of Lilian J. Redstone and others (Oxford: Clarendon, 1966).

7 Derrida, Archive Fever, 90.

8 Ibid., 98-9. The translator indicates that pas is Derrida's term for "step."

9 Emily Steiner, Documentary Culture and the Making of Medieval English Literature (Cambridge: Cambridge University Press, 2003), 93 (emphasis in original).

Io Lawrence Warner, The Lost History of Piers Plowman: The Earliest Transmission of Langland's Work (Philadelphia: University of Pennsylvania Press, 20II).

II As inscribed in British Library (hereafter BL) C.6o.g.I2, Malone's copy of Ritson's Bibliographia Poetica (hereafter BP) (London, I802), 299, 366. The copy is full of such remarks - see Bertrand H. Bronson, Joseph Ritson, Scholar at Arms (Berkeley: University of California Press, 1938), 268 n.96 for a catalogue which is no surprise given Ritson's publication in 1792 of the Cursory Criticisms on the Edition of Shakespeare Published by Edmond Malone, on which see Bronson, 394-403.

I2 George Kane, "The Text," in A Companion to Piers Plowman, ed. John A. Alford (Berkeley: University of California Press, 1988), I76; Ritson, BP, $30 \mathrm{n}$. 
The importance of this comment was first noted by Henry Alfred Burd, Joseph Ritson, A Critical Biography (Urbana: University of Illinois Press, I9I6), I34.

I3 Ritson, BP, 29 n. The text reads "Caligula A. II. I8 B. XVI," but the "II" (i.e., capital Roman numeral two) is a compositor's error for Arabic numeral eleven and "I8 B XVI" is clearly supposed to be Royal I8 B XVII, the error caused by attraction to the "B.xvi" earlier in the line.

I4 Bodleian Douce RR 36, inside front cover. Also in Bronson, Joseph Ritson, 246, who notes the possibility that his annotations to Add. I0285 "were not entered until after Ritson's death" (n.46).

I5 Bronson, Joseph Ritson, 267, quoting from a note signed by Frederick Madden, who attributes the story to Douce himself, in his interleaved copy of the $B P$, now Widener Harvard Depository I0454.I7. On January 3I, I8OI, Ritson had asked Thomas Park to run his eye over the prefaces; Joseph Haslewood says that the mistreatment of Douce occurred "very soon afterward" (Some Account of the Life and Publications of the Late Joseph Ritson, Esq. [London, I824], 26-7; Haslewood's transcription of Park's letter is opposite p. 26 in BL G.I3I23, his copy of that book).

I6 $B P$, ii; Douce RR 36. See also Haslewood, Some Account, 27. Douce would later write to Haslewood, "in spite of himself \& what I might very justifiably term his ingratitude, I really loved the man to an extent that he little dreamt of." Letter of November 5, I823, in the endpapers of BL G.I3I23; quoted also by Bronson, Joseph Ritson, 3II.

I7 For an account of Ritson that analyzes how his madness became part of his story, see David Matthews, The Making of Middle English, I765-I9Io (Minneapolis: University of Minnesota Press, I999), 25-53.

I8 E. Talbot Donaldson, Piers Plowman: The C-Text and Its Poet (New Haven: Yale University Press, 1949; rpt. New York: Frank Cass, 1966), 4-5 n.3 (italics mine), having been alerted by Bronson, Joseph Ritson, 325-6. Donaldson's interpretation would be endorsed by, e.g., Vincent DiMarco, Piers Plowman: A Reference Guide (Boston: G. K. Hall, I982), item I802.I; Eric Dahl, "Diuerse Copies Haue it Diuerselye: An Unorthodox Survey of Piers Plowman Textual Scholarship from Crowley to Skeat," in Suche Werkis to Werche: Essays on Piers Plowman in Honor of David C. Fowler, ed. Míceál F. Vaughan (East Lansing, Mich.: Colleagues Press, 1993), 66; and Charlotte Brewer, Editing Piers Plowman: The Evolution of the Text (Cambridge: Cambridge University Press, 1996), 36 n. 58.

I9 Dahl, "Diuerse Copies," 66.

20 Both Donaldson, The C-Text and Its Poet, 4-5 n.3, and DiMarco, at least, recognize the necessity of separating this supposed insight from his later retreat: "Ritson's comments on the poem in $\mathrm{I} 8 \mathrm{O} 2$, though his final words on the subject, do not represent the entire range of his speculations." DiMarco, "Eighteenth-Century Suspicions Regarding the Authorship of Piers Plowman," Anglia IOO (I982): I28.

2I DiMarco, "Eighteenth-Century Suspicions," I28. DiMarco speculates at I29 that Ritson recognized all this variation by 1780 or so. On internal evidence Bronson dates the contents of these notebooks to $c .1780-c .1800$ (Joseph Ritson, 320 n.4). 
22 Bronson's “A Ritson Bibliography” (Joseph Ritson, 75I-802) was so extensive, commented one reviewer, that "new discoveries about Ritson will be few and relatively unimportant." James M. Osborn, "Joseph Ritson, Scholar at Odds," MP 37 (1940): 429. Yet as Simon Meecham-Jones observes, "Few examples of Ritson's hand survive, particularly from the last few years of his life," and this item is to be dated, as we will see below, to I8OI or I802 (he died September 23, I803). "For Mr. Ritson's Collection: George Ellis, Joseph Ritson and National Library of Wales MSS 5599, 5600c.," English Studies 82 (200I): I29.

23 Facsimile at http://digital.lib.lehigh.edu/cdm4/eb_viewer.php?ptr=IO27, "The Vision of Pierce Plowman, I5O5 [I550]"; this quotation on (Endmatter [I2]). "P.CC." = "printed copies." The attribution of these annotations to Ritson relies both on the correlation between their contents and the $B P$, which also confirms its late date, and on the telltale use of lower-case "i" for the firstperson pronoun, for which he was notorious: "d--n his is" said a contemporary lampoon of Ritson (Bronson, Joseph Ritson, 284, citing Monthly Mirror, August 1803 , 90-2). R. Carter Hailey first recognized the historical value of the Lehigh $\mathrm{Cr}^{\mathrm{I}}$, though he did not identify the annotator as Ritson; see "Robert Crowley and the Editing of Piers Plowman (I550)," YLS 2I (2007): I45 and n.7. I thank Dr. Hailey for his encouragement of my work on this copy.

24 James Nasmith, Catalogus Librorum Manuscriptorum quos Collegio Corporis Christi ... (Cambridge, I777), 327, entry for MS 293. Between the second and third transcriptions from MSS, discussed below, Ritson adds a note indicating that he consulted Nasmith's entry for MS 293.

25 The absence of any transcription from Douce's copy is one indicator, as is the reliance by both documents on George Ellis's I80 Specimens of the Early English Poets (DiMarco, Reference Guide, item I80I.I) in citing Reynold Wolfe's 1553 edition of Pierce the Plowman's Crede as if it were an edition of the poem: BP, $26 \mathrm{n}$; Endmatter [I2] of the Lehigh online copy. That the latter is cancelled suggests that some of the notes in that copy postdate the production of $B P$.

26 Bronson, Joseph Ritson, 79I; see also 797, the entry for the sale catalogue of his books, where Bronson identifies lot 4I7 in the catalogue, "Pierce Plowman, I550," as among its rarer items.

27 In his annotated edition of Rogers's I56I edition, Dr. John Taylor mentions it in shorthand, citing Leland's caleret, i.e., "Hot was the sunne" (Bodleian, $4{ }^{\circ}$ Rawlinson 274, xxxviii ; see Chapter 5). It was likewise discussed by Thomas Warton, Observations on the Faerie Queene of Spenser (London, 1754), 88-9 (see DiMarco, Reference Guide, item I754.I, and Brewer, Editing Piers Plowman, 28); on the flyleaves of Dr. Richard Farmer's copy of Rogers (Haverford College, Magill Library 96; Chapter 5); on the flyleaves of Francis Douce's A-text MS ('“Soft was the sonne' A better reading than 'sette' which is nonsense as appears in P.4 where the morning is mentioned" [Bodleian MS Douce 323, fol. $v^{r}$; Chapter 6]); the margins of Thomas Percy's Crowley (see John J. Thompson, "Bishop Thomas Percy's Contributions to Langland Scholarship: Two Annotated Piers Plowman Prints in Belfast," in The 
Medieval Book and a Modern Collector: Essays in Honour of Toshiyuki Takamiya, ed. Takami Matsuda, Richard A. Linenthal, and John Scahill [Woodbridge: D. S. Brewer, 2004], 457); and in the commentary of Philip Bliss's collations of seven MSS in I8ro (Chapter 5).

28 There is no transcription from Douce's manuscript, Ritson's access to which was surely a casualty of their falling-out; but he does include, indeed begins with, BL MS Royal I8 B xviI, which confirms my emendation of $B P$ (note I3). Ritson also lists the other known witnesses to the poem, but he was relying on catalogues rather than examination. The penultimate page of annotations (Endmatter [II]) announces that "The MSS of this ancient poem are in [blank] Library at Oxford," citing Thomas Tanner, Bibliotheca Britannico-Hibernica (London, 1748), regarding a dozen items.

29 See George Kane, ed., Piers Plowman: The A Version, rev. edn. (London: Athlone Press, 1988), 48 on the extra lines, 8 on the explicit. Ritson also transcribes C.Prol.I-IO, I3 of Cotton Vespasian B XVI (as the first eleven lines appear there) rather than received I-II, and includes "Explicit hic opus hoc" at the end of Caligula A XI.

30 My spot check of his version of the Vernon lines reveals a few minor errors he has wente I wyden for MS wende I wydene; weory for weori; and lenede for leonede - of the sort that he censures severely when they appear in other scholars' published works; but of course there is no indication that this material was for anything other than the preparation of what would become one footnote in the BP. See A Facsimile Edition of the Vernon Manuscript: Oxford, MS. Eng. poet. a.I, Bodleian Digital Texts, ed. Wendy Scase (Oxford: Bodleian, 20I2).

3I BL Additional MS I0285, fol. $247^{\mathrm{v}}$. Lewis infamously writes that Langland "is confused and monotonous, and hardly makes his poetry into a poem": but also, unlike Ritson, grants that he "is a very great poet" for the heights his poetry attains, and "can do some things which Chaucer cannot, and he can rival Chaucer in Chaucer's special excellence of pathos": The Allegory of Love: A Study in Medieval Tradition (Oxford: Oxford University Press, 1936), I6I.

32 The Gentleman's Magazine n.s. I9 (1843): 339: review of The Vision and Creed of Piers Ploughman, ed. Thomas Wright, 2 vols. (London, I842).

33 [Thomas Wright,] "The Visions of Piers Plowman," The Gentleman's Magazine n.s. I (I834): 386. On Whitaker's edition, see Brewer, Editing Piers Plowman, 37-45, and Sarah A. Kelen, Langland's Early Modern Identities (New York: Palgrave Macmillan, 2007), I07-26.

34 The attribution is in James M. Kuist, The Nichols File of The Gentleman's Magazine: Attributions of Authorship and Other Documentation in Editorial Papers at the Folger Library (Madison: University of Wisconsin Press, 1982), IIO. The places it would have been discussed had its existence been known are Brewer, Editing Piers Plowman, and Kelen, Langland's Early Modern Identities. Arthur Sherbo cites another item from the magazine missing from DiMarco's book, "probably because it is not listed in the index volumes of the GM": "Samuel Pegge, Thomas Holt White, and Piers Plowman," YLS I (1987): I23. 
35 W. P. Courtney, "Mitford, John (I78I-I859)," rev. James Edgar Barcus, Jr., $O D N B$, www.oxforddnb.com/view/article/18856, the source for further information cited below.

36 A reproduction of the page, the recto of the second flyleaf, is available in the online version of my essay on Mitford's copy: “The Gentleman's Piers Plowman: John Mitford and his Annotated Copy of the 1550 Edition of William Langland's Great Poem," The La Trobe Journal 84 (2009): IO4-I2, www.slv.vic.gov.au/latrobejournal/issue/latrobe-84/tI-g-tio.html, figure I. The clipping is from Catalogue of the Very Select and Valuable Library of William Roscoe Esq. (London, I8I6), lot 132I. The description of a Rogers, whereabouts now unknown, Lot 47 of The Trivulzio Collection. Part the Second (catalogue of sale, 6-II February, I888), pp. I8-I9, refers to a memorandum to which is "affixed a catalogue cutting of Alexander Pope's copy, priced £28." Similarly, in another Rogers, Bodleian Douce L 195, someone has written, "Popes copy of this edition was in $\mathrm{Mr}$ Roscoe's library" (recto of second flyleaf). The Pope/Warton copy is item 25I in a catalogue of Pope materials issued $c .2012$ by Ximenes Rare Books, Kempsford, Gloucestershire (price £20,000): www.ilab.org/catalog_view/739/ 739_Pope\%20catalogue.pdf; it is now in the hands of a private owner whom I thank for answering my queries about it.

37 Thomas Tyrwhitt, ed., The Canterbury Tales of Chaucer, 5 vols. (London, I775-8), 4:74; Ritson, $B P$, $30 \mathrm{n}$. In the Crowley note regarding the two sets of witnesses, discussed above, Ritson continues: "I have never met with a MS. more correct or better deserving of publication than Crowleys editions; \& suppose that Mr. Tyrwhitt had not examined as many as I have done, nor marked the above difference" (Endmatter [I2]). The catalogue of eighteenthcentury recognition of MS variation I give here is widely rehearsed, with the exception of Nasmith, whose role has to my knowledge gone unnoticed. See, e.g., Donaldson, C-Text and Its Poet, 3-7; Kane, "The Text," I76-7; and the opening chapters of Brewer, Editing Piers Plowman, 7-49.

38 Thomas Warton, The History of English Poetry ... : A New Edition Carefully Revised [by Richard Price], 4 vols. (London, I824), 2:482. Critics commonly credit Price with "discovering" the A version, but this is very misleading. The copy in which he identified this third version has what we now call a "C continuation" and thus is some 4,500 lines longer than the "A version" we now know, whose most distinctive characteristic is precisely its relative shortness. Brewer, too, points this out, also noting a few other problems with his textual analysis, with the caveat that "it is distinctly ungenerous to cavil at these shortcomings given Price's notable gains on the work of his predecessors" (Editing Piers Plowman, 47).

39 Mitford, review, p. 344, n.

40 Wright, Vision, i:xli.

4I For a summary of the situation see Brewer, Editing Piers Plowman, I8I-208; the phrase first appeared prominently in J. J. Jusserand, "Piers Plowman: The Work of One or of Five," MP 6 (I909): 27I-329, arguing for single authorship. 
42 George P. Marsh, The Origin and History of the English Language, and of the Early Literature It Embodies (London, I862), 297. For a biography see David Lowenthal, George Perkins Marsh: Versatile Vermonter (New York: Columbia University Press, 1958).

43 John M. Manly, "The Authorship of Piers the Plowman," MP I4 (I9I6): 316.

44 Morton W. Bloomfield, "Present State of Piers Plowman Studies," Speculum I4 (1939): 2I5; Brewer, Editing Piers Plowman, I84 and n.3.

45 Wright, Vision, I:xli.

46 Ibid.

47 Brewer, Editing Piers Plowman, 426-7.

48 See www.mla.org/resources/awards/awards_submissions/awards_competitions/ prizes_biennial20I4/prizeinfo_bib.

49 A. S. G. Edwards, "Shapes Arbitrarily Determined," Times Literary Supplement 5662 (October 7, 20II): 27. See also, e.g., Brewer, Editing Piers Plowman, 426: the PPEA "has a claim to being the perfect solution to the dilemma confronting would-be editors and readers of the poem in the post-KaneDonaldson era" followed by the comments above; and C. David Benson, Public Piers Plowman: Modern Scholarship and Late Medieval English Culture (University Park: Pennsylvania State University Press, 2004), 57-8, on how it frees readers from the confines inherent in the Athlone edition.

50 Hoyt N. Duggan, "I994 Prospectus: Creating an Electronic Archive of Piers Plowman," section II, www3.iath.virginia.edu/seenet/piers/archivegoalsig94 body.html.

5I PPEA, "Creating the Archive": http://piers.iath.virginia.edu/about/creating. html. This website was launched in 20I2; the project originally began in 1990. All quotations from the archive are from this page.

52 A. V. C. Schmidt, Piers Plowman: A Parallel-Text Edition of the A, B, C and $Z$ Versions, Vol. 2, Introduction, Textual Notes, Commentary, Bibliography and Indexical Glossary (Kalamazoo: Medieval Institute Press, 2OII), 2. The PPEA's list of MSS is available in any published edition and most easily accessible in Hoyt N. Duggan, with a contribution from Eugene Lyman, "A Progress Report on The Piers Plowman Electronic Archive," The Digital Medievalist I (2004), www.digitalmedievalist.org/journal/I.I/duggan/\#d33284e755. That essay's Appendix I, "New Sigils for the PPEA" (\$I7), lists the same fiftyeight MSS as does Ralph Hanna, William Langland (Aldershot: Variorum, I993), 38-42, acknowledging it as source of these excerpts.

53 The omission of the Caius MS is surely owing to the editors' reliance on Ralph Hanna's 1993 list of manuscripts, which mentions it not in the list of MSS (where the other three do appear), but in its entry for " $\mathrm{Cr}^{4}$," Rogers's edition, in his discussion of the printed copies (William Langland, 42). Hanna is inconsistent on this front: he describes Oxford, Bodleian Library MSS Wood donat. 7 (Wb in the PPEA), his number 38, as "probably from Crowley," and James 2, part I, as "from a MS. like BmBoCot, to the last of which the copyist Richard James certainly had access" (40). But such inconsistencies are inevitable; Hanna deserves full credit for bringing these items into public view. 
54 This and the following are the copies that Walter Skeat and Mr. D. Hall produced, using the Ilchester MS (University of London Library MS S.L. V.88) and C.U.L. MS Ff.5.35 as exemplars, respectively, in preparation for Skeat's edition of C.

55 Carl Grindley, "A New Fragment of the Piers Plowman C Text?" YLS II (1997): 135-40.

56 This appears on p. 550 of that MS. It is a version of A 4.I5-I7 in a hand unattested elsewhere in the volume, which to my knowledge no one has ever mentioned. Though its text is unique as well, it is not of any textual authority: its appearance at the top of the first page of a new gathering (the second of Piers Plowman and twenty-second of the manuscript) shows that, before the manuscript was bound, the individual who inscribed the excerpt on the final verso made a rough copy of the lines in the identical location on the loose quire on his desk, the one that now begins at p. 495. There are at least two special cases. $\mathrm{Hm}^{2}$ is an excerpt included in Huntington MS $\mathrm{Hm}$ I28, whose main text is $\mathrm{Hm}$, which on the one hand does not get its own entry in these lists, but on the other retains separate sigils, in violation of the PPEA editors' claim that they "have chosen to represent each manuscript with a unique sigil" (Duggan and Lyman, "Progress Report," \$ 17 ). And Bodley 851, quite apart from the single line I list above, contains three texts most likely in three separate hands (George Russell and George Kane, eds., Piers Plowman: The C Version, [London: Athlone Press, 1997], 19); but the Piers Plowman that results is certainly intended to make up a single production.

57 See George Kane and E. Talbot Donaldson, eds., Piers Plowman: The $B$ Version rev. edn. (London: Athlone Press, 1988), I.

58 See my "Latin Verses by John Gower and 'John of Bridlington' in a Piers Plowman Manuscript (BL Add. 35287)," N\&QQ 55 (2008): 127-31.

59 John M. Bowers, Chaucer and Langland: The Antagonistic Tradition (Notre Dame, Ind.: University of Notre Dame Press, 2007), 4I, I26, likewise relying on Hanna, William Langland, 37-42, and adding the four-line extract of Prol.I-4 mentioned above that the PPEA includes and that is now published and discussed in Wendy Scase, "Dauy Dycars Dreame and Robert Crowley's Prints of Piers Plowman," YLS 2I (2007): I86-7.

60 As in, e.g., Michael G. Sargent, "What Do the Numbers Mean? A Textual Critic's Observations on Some Patterns of Middle English Manuscript Transmission," in Design and Distribution of Late Medieval Manuscripts in England, ed. Margaret Connolly and Linne R. Mooney (York: York Medieval Press, 2008), 205-44. See Warner, Lost History, 74 n.IO on other problems with Sargent's figures.

6I Benson, Public Piers Plowman, xii. The first half of the book, Chapters I-3 (pp. 3-II2), treats "the Langland myth."

62 Ibid., xiii.

63 Thompson, "Bishop Thomas Percy's Contributions to Langland Scholarship," 452.

64 Michel Foucault, The Archaeology of Knowledge and The Discourse on Language, trans. A. M. Sheridan Smith (New York: Tavistock, 1972), 26. 


\section{William and the werewolf}

I See, respectively, Brian Vickers, Shakespeare, A Lover's Complaint, and John Davies of Hereford (Cambridge: Cambridge University Press, 2007), and James I. Wimsatt, Chaucer and the Poems of "Ch" (Woodbridge: D. S. Brewer, 1982).

2 See Simon Horobin, "A Manuscript Found in the Library of Abbotsford House and the Lost Legendary of Osbern Bokenham," English Manuscript Studies IIO0-I700 I4 (2007): 132-64 and "Politics, Patronage, and Piety in the Work of Osbern Bokenham," Speculum 82 (2007): 932-49.

3 For arguments that the first portion of Piers Plowman in Oxford, Bodleian MS Bodley 85I represents an early authorial version, see Charlotte Brewer, "The Z-Text of Piers Plowman," in Piers Plowman: A Facsimile of the Z-Text in Bodleian Library, Oxford, MS Bodley 85I, intro. Brewer and A. G. Rigg (Cambridge: D. S. Brewer, 1994), I-22, and Schmidt, Parallel-Text, 2II-30. For the idea that A is a later digest of B and C, see Jill Mann, "The Power of the Alphabet: A Reassessment of the Relation between the A and the B Versions of Piers Plowman," YLS 8 (1994): 2I-50 (cf. Warner, Lost History, 25-7).

4 Quotations are from William of Palerne, an Alliterative Romance, ed. G. H. V. Bunt (Groningen: Bouma's Boekhuis, 1985). The poem is attested only in Part I of Cambridge, King's College MS I3, of the later fourteenth century (3).

5 Winner and Waster may have been written as early as 1352, but David A. Lawton dates it after Piers Plowman A: "The Unity of Middle English Alliterative Poetry," Speculum 58 (I983): 80-I.

6 Lawton, "Unity," argues that the influence of Piers Plowman A brings about the unity of this corpus. William of Palerne is the only exception unquestionably dated before the A version.

7 See Hanna, William Langland, 2-3, 26, and Robert Adams, Langland and the Rokele Family: The Gentry Background to Piers Plowman (Dublin: Four Courts Press, 20I3).

8 Ardis Butterfield, The Familiar Enemy: Chaucer, Language, and Nation in the Hundred Years War (Oxford: Oxford University Press, 2009), 286. For recent treatments of Langland and the French tradition see Andrew Galloway, The Penn Commentary on Piers Plowman, Vol. I: C Prologue-Passus 4; B ProloguePassus 4; A Prologue-Passus 4 (Philadelphia: University of Pennsylvania Press, 2006), which explores the parallels between Piers Plowman and the Roman de la Rose, and Nicolette Zeeman, "Tales of Piers and Perceval: Piers Plowman and the Grail Romances," YLS 22 (2008): 199-236.

9 Respectively, Angus McIntosh, "Early Middle English Alliterative Verse," in Middle English Alliterative Poetry and Its Literary Background: Seven Essays, ed. David A. Lawton (Cambridge: D. S. Brewer, 1982), 25; Lawton, "Alliterative Style," in Alford, A Companion to Piers Plowman, 245.

Io George Kane, "Langland and Chaucer II," in Chaucer and Langland: Historical and Textual Approaches (London: Athlone Press, 1989), 282 n.4. "When I first aired this notion years ago I was sharply told by philologists that there were 
linguistic reasons why Langland could not have written William of Palerne. I accepted this because I did not know then what scribes could do to the language of texts."

II Galloway, Penn Commentary, I4, referring to the earlier version of this chapter (Viator 37 [2006]: 397-415).

I2 Schmidt, Parallel-Text, 272; see, e.g., 267 nn.45-55. Ralph Hanna says, "Piers has more in common, stylistically and metrically, with [William of Palerne] than with any text of the later 'central tradition'," but does not suggest any direct connection between the two (London Literature, I300-I380 [Cambridge: Cambridge University Press, 2005], 259).

I3 I.e., Will "wrousthe pat here is wryten" - Piers Plowman - "and oper werkes bope" (bothe = too, also) (A I2.IOI); see my "John But and the Other Works that Will Wrought (Piers Plowman A xiI IOI-2)," NeQ 52 (2005): I3-I8.

I4 See Anne Middleton, "William Langland's 'Kynde Name': Authorial Signature and Social Identity in Late Fourteenth-Century England," in Literary Practice and Social Change in Britain, I380-I530, ed. Lee Patterson (Berkeley: University of California Press, I988), I5-82.

Is George Kane, Middle English Literature: A Critical Study of the Romances, the Religious Lyrics, Piers Plowman (New York: Barnes and Noble, 1951), I86, I89-90.

I6 On "William" as Langland's most likely given name, see George Kane, Piers Plowman: The Evidence for Authorship (London: Athlone Press, 1965), 26-70 (65-70 on the acrostic). David Lawton has suggested that the "William" whose work has ended in line 552I might refer to the protagonist rather than the poet, as reported by Richard Firth Green, "Humphrey and the Werewolf," in Medieval Alliterative Poetry: Essays in Honour of Thorlac Turville-Petre, ed. John A. Burrow and Hoyt N. Duggan (Dublin: Four Courts Press, 20Io), IO7-8 n.5.

I7 The first notice of the reference to the great storm was Tyrwhitt, Canterbury Tales, 5:v. See also Piers Plowman: The Z Version, ed. A. G. Rigg and Charlotte Brewer (Toronto: Pontifical Institute of Mediaeval Studies, 1983), 20, on their Z 5.32 .

I8 Respectively, Gerrit H. V. Bunt, "Localizing William of Palerne," in Historical Linguistics and Philology, ed. Jacek Fisiak (Berlin and New York: Mouton, 1990), 82, and J. P. Oakden, Alliterative Poetry in Middle English: The Dialectal and Metrical Survey (Manchester: Manchester University Press, 1930), 56.

I9 The language of Harley 2376 has been thoroughly translated by its scribe: see Merja Black, "A Scribal Translation of Piers Plowman," ME 67 (1998): 25790. On the language of Trinity B.I5.I7, see The Piers Plowman Electronic Archive, Vol. 2: Cambridge, Trinity College, MS B.IS.I7 (W), ed. Thorlac Turville-Petre and Hoyt N. Duggan (Ann Arbor: SEENET and University of Michigan Press, 2000), Introduction.

20 A. V. C. Schmidt, The Clerkly Maker: Langland's Poetic Art (Cambridge: D. S. Brewer, 1987), I03, I04 (see I02-7). On William of Palerne's relationship to Guillaume de Palerne, see the convenient summaries by W. R. J. Barron, 
"Alliterative Romance and the French Tradition," in Lawton, Middle English Alliterative Poetry, 75-80, and Bunt, William of Palerne, 30-6.

2I E.g., the "passion tag" found at Piers Plowman A 2.3 and so important in William of Palerne: lines 1669, I802, 2083, 2360, 5534, part of a larger program analyzed by Roger Dalrymple, Language and Piety in Middle English Romance (Cambridge: D.S. Brewer, 2000), 64-8I. On alliterative poets' use of such formulas see Thorlac Turville-Petre, The Alliterative Revival (Cambridge: D. S. Brewer, 1977), 28-9. The difficulties inherent in such comparisons of vocabulary, sentence length, and the like are stressed by R. A. Cooper and Derek A. Pearsall, "The Gawain Poems: A Statistical Approach to the Question of Common Authorship," RES n.s. 39 (I988): 370-3.

22 Galloway, Penn Commentary, I9; see also Walter W. Skeat, ed., The Vision of William Concerning Piers the Plowman in Three Parallel Texts, 2 vols. (London: Oxford University Press, I886), 2:I. Another potentially interesting word is trieliche (A and B Prol.I4), attested elsewhere in William of Palerne but nowhere else, but that is still "perhaps not so remarkable" since variants appear elsewhere. Turville-Petre, review of Galloway, in YLS 20 (2006): 232.

23 Cooper and Pearsall, "The Gawain Poems," 372; see also Helen Barr, "The Relationship of Richard the Redeless and Mum and the Sothsegger: Some New Evidence," YLS 4 (1990): I05-33. The first of these, the distribution of unstressed syllables, would work only if scribes never left their marks on the texts; the second, the use of and or but at line-opening, is useless for our situation, since many of these in William of Palerne simply render the equivalent terms in its French source, a problem exacerbated by the presence of anaphoric sequences such as the passage in which nine straight English verses (lines 1363-7I) and eight of eleven French verses (lines 2500-IO) begin with andlet. The French poem is cited from Guillaume de Palerne: roman du XIIIe siècle, ed. Alexandre Micha (Geneva: Droz, I990).

24 George Kane, "Outstanding Problems of Middle English Scholarship," in Chaucer and Langland, 233. The renewed prominence of such tests by, e.g., Cooper and Pearsall, "The Gawain Poems," 376-82, signals a new version of the circularity that bedevilled the authorship controversy last century, during which, as Anne Middleton observes, it became clearer to all parties that the appearance of critical editions would not solve the problem, since such texts are the products of critical assumptions regarding the very characteristics that would subsequently be tested. "Piers Plowman," in A Manual of the Writings in Middle English, I050-I500, ed. Albert E. Hartung (New Haven: Connecticut Academy of Arts and Sciences, 1986), 2226-7.

25 On Langland's meter, see, e.g., Hoyt N. Duggan, "Notes on the Metre of Piers Plowman: Twenty Years On," in Approaches to the Metres of Alliterative Verse, ed. Judith Jefferson and Ad Putter (Leeds: Leeds Studies in English, 2009), I59-86, and Schmidt, Parallel-Text, 253-60. Bunt analyzes the meter of the extant text of William of Palerne, but he makes no attempt to distinguish the author's metrical practices from that text's (William of Palerne, 77-84).

26 Turville-Petre, review of Galloway, 23I. 
27 Christine Chism, Alliterative Revivals (Philadelphia: University of Pennsylvania Press, 2002), 19. For consideration of how Langland would have responded to William of Palerne if he had read it, see S. S. Hussey, "Langland's Reading of Alliterative Poetry," Modern Language Review 60 (1965): 163-70.

28 Turville-Petre, review of Galloway, 232, saying that "if Langland composed [William of Palerne], he had lost all his naïveté (and much of his charm) by the time he wrote Piers Plowman."

29 Ibid. See the similar remarks by Elizabeth D. Kirk, The Dream Thought of Piers Plowman (New Haven: Yale University Press, 1972), I9 n.4.

30 The Romance of William of Palerne, or, William and the Werwolf: Together with a Fragment of the Alliterative Romance of Alisaunder, ed. Walter W. Skeat, EETS e.s. I (London: Oxford University Press, I867), v.

3I On this aspect of the poem see Arlyn Diamond, "Loving Beasts: The Romance of William of Palerne," in The Spirit of Medieval English Popular Romance, ed. Ad Putter and Jane Gilbert (London: Pearson, 2000), I48-9, and Dalrymple, Language and Piety, 69-70.

32 Translations are from Guillaume de Palerne: An English Translation of the I2th Century French Verse Romance, ed. and trans. Leslie A. Sconduto (Jefferson, N.C.: McFarland, 2004).

33 David Mills, "The Rôle of the Dreamer in Piers Plowman," in Piers Plowman: Critical Approaches, ed. S. S. Hussey (London: Methuen, 1969), I85; see Galloway, Penn Commentary, 28-9 for another recent articulation of the assumption. Regarding the other longstanding misconception surrounding these lines - that line 2's "shep" might mean "shepherd" - Turville-Petre has said that Galloway, 27-8, "puts the kibosh on that and shows once and for all that it means 'sheep" (review, 232); Schmidt, too, says "shepherd" "finds no lexical support" (Parallel-Text, 305).

34 Respectively, Dee Dyas, "A Pilgrim in Sheep's Clothing? The Nature of Wandering in Piers Plowman," English Language Notes 39.4 (2002): 4; David Lyle Jeffrey, "Wolves in Sheep's Clothing," in A Dictionary of Biblical Tradition in English Literature, ed. Jeffrey (Grand Rapids, Mich.: Eerdmans, 1992), 844. Langland's sole unequivocal employment of the figure, quite opposed to the opening lines, accords with normative usage: "Riht so many prestes, prechours and prelates, / That ben enblaunched with bele paroles and with bele clothes / And as lambes they loke and lyven as wolves" (C I6.269-7I).

35 Derek Pearsall, Piers Plowman: A New Annotated Edition of the C-Text (Exeter: University of Exeter Press, 2008), 43, n. to C Prol.3, citing Mills, "Rôle of the Dreamer," I86. See also George Kane, "Poetry and Lexicography in the Translation of Piers Plowman," in Chaucer and Langland, 95, and Galloway, Penn Commentary, 30-I. Schmidt deems this interpretation "lexically possible but unlikely" (Parallel-Text, 47I).

36 What Hoyt N. Duggan identifies as the correspondence, "in almost every case," of the alliterative line's caesura to "a major syntactic disjuncture" supports this reading: "Notes Toward a Theory of Langland's Meter," YLS I (I987): 44 (Metrical Rule IV). While Macklin Smith has both argued against 
Duggan's claim and deemed the association of "unholy of werkes" with the hermit "the more natural reading" ("Langland's Unruly Caesura," YLS 22 [2008]: IOO), the b-verse's inaugural unstressed syllable is here not on a preposition or conjunction, as so often in the surrounding lines ("whan softe"; "as y"; "on Malverne hulles"; "of fairie"; "\&wente" [A Prol.I, 2, 5, 6, 7]), reinforcing the power of the syntactical break between "hermite" and "unholy." Will's later request of Holy Church, "Teche me to no tresour but tel me pis ilke, / How I may saven my soule, pat seint art yholden" (A I.8I-2), likewise features a clause subordinate to an understood pronoun. A lengthy separation of a clause from its referent, as between line $3 \mathrm{~b}$ and $2 \mathrm{a}$ in my construal, appears in the English William of Palerne (it is not in Guillaume 492-5), when the cowherd, commanded by the emperor to explain the circumstances of William's discovery, describes "How he him fond in pat forest pere fast biside, / Cloped in comly cloping for any kinges sone, / Under an holw ok, purth help of his dogge" (293-5). See also Kane, "Poetry and Lexicography," 95, on the caesura.

37 The Twelve Books of John Cassian on the Institutes of the Coenobia, in A Select Library of Nicene and Post-Nicene Fathers of the Christian Church, Second Series, trans. Edgar C. S. Gibson, Vol. II (New York, I894), I.7, cited in John M. Bowers, The Crisis of Will in Piers Plowman (Washington, D.C.: Catholic University of America Press, 1986), I02 n.I8. See also Galloway, Penn Commentary, 29.

38 Lawton, "The Unity of Middle English Alliterative Poetry," 77.

39 Cited by Skeat, Parallel Texts, 2:247-8.

40 On But's term, see my "John But and the Other Works that Will Wrought."

4I See Bunt, William of Palerne, 305-6, and Galloway, Penn Commentary, 38-9. Cf. Clergie's remark to Conscience: "bow shalt se pe tyme / When pow art wery forwalked" (B I3.203-4).

42 Penn R. Szittya cites applications of the "wolves in sheep's clothing" motif to friars in Pierce the Ploughman's Crede, Henryson, the Romaunt of the Rose, Gower, Audelay (on whom see below), Upland's Rejoinder, and some anonymous verses. The Antifraternal Tradition in Medieval Literature (Princeton: Princeton University Press, 1986), 2II-I2 and 2II n.84.

43 Olive Sayce, "Chaucer's 'Retractions': The Conclusion of the Canterbury Tales and Its Place in Literary Tradition," $M E 40$ (I97I): 238 (main), 242 ("topos of regret").

44 Cited from the edition by A. S. G. Edwards and M. C. E. Shaner, in The Riverside Chaucer, gen. ed. Larry D. Benson, 3rd edn. (Boston: Houghton Mifflin, 1987). See Kathryn Kerby-Fulton, "Langland and the Bibliographic Ego," in Written Work: Langland, Labor, and Authorship, ed. Steven Justice and Kathryn Kerby-Fulton (Philadelphia: University of Pennsylvania Press, 1997), 80.

45 Hanna, London Literature, I49.

46 Steiner, Documentary Culture, IIs (Ancrene Wisse), II6 (quotation).

47 Ancrene Wisse, Parts Six and Seven, ed. Geoffrey Shepherd (Manchester: Manchester University Press, 1972), 2I:4-5. 
48 Steiner, Documentary Culture, II6; on I8.I86 see also Stephen A. Barney, The Penn Commentary on Piers Plowman, Vol. 5: C Passus 20-22; B Passus I8-20 (Philadelphia: University of Pennsylvania Press, 2006), 50-I.

49 This is quite close to the French (8399-403). Messengers bear letters in other episodes (e.g., I422-59 and 4I5I-283), though none is as close to the instances Steiner discusses as this.

50 The subsequent episodes of the "spectacular triple marriage and one abortive but also splendid preparation for marriage," as well, look forward in interesting ways to the marriage of Meed in Piers Plowman A 2, as Galloway notes (Penn Commentary, 248, referring to I463-63I, 4990-5IO5). He remarks that "the broader setting in A [2.40-2], cut from the later versions, parallels the first, paternally arranged marriage in William of Palerne [lines I625-3I]"; also 249, 252,255 .

5I In the note to this line in William of Palerne: An Electronic Edition (Ann Arbor: University of Michigan Press, 2002), Bunt observes that "the alliteration could be improved if for [the MS reading] crist we read god," though he does not emend. This edition includes a color digital facsimile of the entire poem, but much less of the supporting apparatus found in the hard-copy edition.

52 See C. W. Marx, The Devil's Rights and the Redemption in the Literature of Medieval England (Cambridge: D. S. Brewer, 1995).

53 Wilber Gaffney, "The Allegory of the Christ-Knight in Piers Plowman," PMLA 46 (I93I): 156. See also Nicole Clifton, "The Romance Convention of the Disguised Duel and the Climax of Piers Plowman," YLS 7 (1993): 123-8.

54 Augustine: Sermons on the Liturgical Seasons, trans. Mary Sarah Muldowney (New York: Fathers of the Church, 1959), 392; I substitute "mousetrap" for "trap" for the term muscipula.

55 One analogue in the sermonic tradition survives, but it focuses on a fine doctrinal point and does not appear, as in Piers Plowman, in the center of the drama of Atonement. See my "Jesus the Jouster: The Christ-Knight and Medieval Theories of Atonement in Piers Plowman and the 'Round Table' Sermons," YLS Io (1996): I29-43.

56 Audelay's anthology of verse is in Oxford, Bodleian MS Douce 302; on this manuscript and the poet's life, see My Wyl and My Wrytyng: Essays on John the Blind Audelay, ed. Susanna Fein (Kalamazoo: Medieval Institute, 2009). Two arguments that Audelay read Langland are James Simpson, "Saving Satire after Arundel's Constitutions: John Audelay's Marcol and Solomon," in Text and Controversy from Wyclif to Bale: Essays in Honour of Anne Hudson, ed. Helen Barr and Ann M. Hutchison (Turnhout: Brepols, 2005), 387-404, and Richard Firth Green, "Langland and Audelay," in Fein, 153-69; one against is Derek Pearsall, "Audelay's Marcolf and Solomon and the Langlandian Tradition," in Fein, 138-52.

57 Michael J. Bennett, "John Audley: Some New Evidence on His Life and Work," Chaucer Review I6 (1982): 344-55. Bennett finds "certain themes which might have stemmed from this traumatic experience" (35I-2), and judges it "very probable" that he had written secular verse that "would have 
been rapidly jettisoned when he retired to Haughmond to compile his Concilium conciencie" (353).

58 Ibid., 353.

59 Adams, Langland and the Rokele Family, 105-20. For a bibliography of other recent approaches to the question of Langland's patronage see $97 \mathrm{nn} .53-4$. On Humphrey and the question of the poem's readership, see Bunt, William of Palerne, I4-I9 and references.

60 Adams, Langland and the Rokele Family, ro8.

6I See, e.g., Chris Given-Wilson, The English Nobility in the Late Middle Ages (1987; New York: Routledge, I996), 32.

62 See The Complete Peerage of England, Scotland, Ireland, Great Britain and the United Kingdom ... , ed. G. E. Cokayne; new edn., rev. Vicary Gibbs, Geoffrey H. White, et al., I3 vols. in I4 (London: St. Catherine, I9IO-59), 2:535-6.

63 Humphrey, second earl of Hereford ( $1208-75$ ), was father of Alice Bohun, m. Roger de Toeni (c.1235-64) $>$ Ralph de Toeni (1255-95) $>$ Alice de Toeni, m. Guy de Beauchamp $>$ Thomas Beauchamp. See Emma Mason, Beauchamp Cartulary Charters, II00-I268 (London: Pipe Roll Society, 1980), 2I4-I6 on Alice Bohun's marriage and motherhood, correcting The Complete Peerage, I2.I:77I-2. On Ralph de Toeni and his daughter Alice, see Complete Peerage, I2.I:774 n.i (entry for Robert de Toeni), and I2.2:37I-2 (entry for Guy de Warwick). On Thomas Beauchamp, see Anthony Tuck, "Beauchamp, Thomas, Eleventh Earl of Warwick (I313/I4-I369)," in $O D N B$, www.oxforddnb.com/view/article/53085. The Bohun line goes through Alice Bohun's brother Humphrey (d. 1265) > Humphrey, third earl (d. I298) > Humphrey, fourth earl (d. I322) > Humphrey, sixth earl (whose brother John, fifth earl, pre-deceased him). See Complete Peerage, 6:459-62.

64 Michael J. Bennett, "William Called Long Will,” YLS 26 (2012): I-25.

65 Thomas's sister Philippa married Hugh Stafford $c .1350$, and Ralph was their son, and Hugh was devastated by his death. See Carole Rawcliffe, "Stafford, Hugh, Second Earl of Stafford (c.1342-1386)," in ODNB, www.oxforddnb. $\mathrm{com} /$ view/article/26206.

66 Waldegrave was a retainer in the household of William de Bohun, earl of Northampton and brother of the patron of the William of Palerne poet, whose son Humphrey succeeded his uncle Humphrey as earl of Hereford and Essex. See J. S. Roskell, "Sir Richard de Waldegrave of Bures St. Mary, Speaker in the Parliament of I38I-2," Suffolk Institute of Archaeology 27.3 (1957): 154-75, esp. 156-7 on his service for the Bohuns.

67 Simpson, "Saving Satire," 402; see Szittya, Antifraternal Tradition, 247-87 on Langland's antifraternalism. The judgment about Humphrey's generosity is by Aubrey Gwynn, The English Austin Friars in the Time of Wyclif (London: Oxford University Press, I940), I09. On Humphrey's sympathy with many of the themes and approaches of William of Palerne, see Green, "Humphrey and the Werewolf." 
68 Lucy Freeman Sandler, "A Note on the Illuminators of the Bohun Manuscripts," Speculum 6o (I985): 364. This is John de Teye, bequeathed EIo to pray for Humphrey's soul, with an additional 40 shillings; see 365-6.

69 See Michael J. Bennett, "Mandeville's Travels and the Anglo-French Moment," $M A E 75$ (2006): 279-80, on the basis of its early date and his patronage of the arts and of the Austin friars, particularly in York. On Erghome's authorship of the commentary, see A. G. Rigg, "John of Bridlington's Prophecy: A New Look," Speculum 63 (1988): 596-613.

70 See, respectively, The Friars' Libraries, ed. K. W. Humphreys (London: British Library, 1990), xxiv-xxvii, II-I54, and Hanna, William Langland, 35.

7I See Andrew Galloway, "The Rhetoric of Riddling in Late-Medieval England: The 'Oxford' Riddles, the Secretum philosophorum, and the Riddles in Piers Plowman," Speculum 70 (I995): 68-IO5. In addition, a Leonine verse from the prophecy on which Erghome commented would end up after Langland's poem in an early MS: see my "Latin Verses by John Gower and 'John of Bridlington'."

72 I am grateful to Stephen A. Barney for suggesting the pertinence of the Austin friars to the opening lines in this context. See his Penn Commentary, 196.

73 This sentence is a précis of my book Lost History.

\section{Localizing Piers Plowman C}

I David Wallace, Premodern Places: Calais to Surinam, Chaucer to Aphra Behn (Oxford: Blackwell, 2004), I5.

2 Walter W. Skeat, ed., The Vision of William Concerning Piers the Plowman: The "Whitaker" Text; or Text C, EETS o.s. 54 (London: Trübner, I873), lxxiv on the return to Malvern, citing as well the sense that in C London is a thing of the past, and the fact that Richard the Redeless, which he believed to be by Langland, is centered upon Bristol; lxxix on the poet growing conservative as he grew older.

3 Steven Justice, Writing and Rebellion: England in 1381 (Berkeley: University of California Press, 1994), 233, 239. See the similar line of argument in Bowers, Chaucer and Langland, 6O-I, I22.

4 M. L. Samuels, "Langland's Dialect," $M E 54$ (1985): 239, concluding that "Skeat's view that the author returned to Malvern in later life is thus shown to be highly probable" (240). The " $i$-group" is so called from the time when the Ilchester MS, MS J or I, was its representative witness. It comprises MSS XYJP²UDH: see Russell and Kane, The C Version, 4I-6.

5 Simon Horobin, "In London and Opelond': The Dialect and Circulation of the C Version of Piers Plowman," MAE 74 (2005): 263. His evidence for XYJUH's origins in London inheres in the fact that "certain features of the handwriting, ordinatio, and layout of the $i$-group of $\mathrm{C}$ manuscripts point to connections between them, and suggest links with the professional London book trade"; he comments as well on similarities in the hands of these scribes (25I). Samuels acknowledges that MS J was "copied in London" and says that 
X shows "some slight signs of interference typical of a London copying" ("Langland's Dialect," 239-40).

6 C 5.44 in both Schmidt, Parallel-Text and Pearsall, A New Annotated Edition.

7 Anne Middleton, “Acts of Vagrancy: The C Version 'Autobiography' and the Statute of 1388," in Justice and Kerby-Fulton, Written Work, 253.

8 Chism, Alliterative Revivals, 9.

9 See Russell and Kane's apparatus and The C Version, I54. Joseph S. Wittig, "Culture Wars' and the Persona in Piers Plowman," YLS I5 (200I): I69-70, discussing Middleton's reading (see 7 note above), makes a similar point. On the P-group see Russell and Kane, 46-58.

Io Russell and Kane, The $C$ Version, I54.

II Skeat, Parallel Texts, 2:62, gloss to (his) C 6.44.

I2 Russell and Kane, The $C$ Version, I54. They begin by noting that "the implied self-criticism, of parasitism, is also contextually apt," and concluding: "The form $u p$, not actually attested, is adopted as likelier than upon to have generated the variant opelond. See $O E D$ s.v. $U_{p}$ prep. ${ }^{\text {I }}$ II 4 . Some scribes, understanding the meaning well enough, preferred on or by."

I3 Skeat, The Vision of William ... Text $C$, lxxiv.

I4 Bowers, Chaucer and Langland, 77; likewise Kathryn Kerby-Fulton and Steven Justice say that the Ilchester MS bears "some important marks of proximity to the author" ("Scribe D and the Marketing of Ricardian Literature," in The Medieval Professional Reader at Work: Evidence from Manuscripts of Chaucer, Langland, Kempe, and Gower, ed. Kathryn KerbyFulton and Maidie Hilmo [Victoria, B.C.: University of Victoria, 200I], 2I7). As Linne R. Mooney and Estelle Stubbs say, "it is possible that [John] Marchaunt (Scribe D) and Langland knew each other" any time from the late I36os, when Marchaunt might already have been at the Guildhall, but even if so that acquaintance did not result in access to privileged authorial materials. Scribes and the City: London Guildhall Clerks and the Dissemination of Middle English Literature, 1375-I425 (York: York Medieval Press, 2013), 58.

I5 A Linguistic Atlas of Late Mediaeval English, ed. Angus McIntosh, M. L. Samuels, and Michael Benskin, 4 vols. (Aberdeen: Aberdeen University Press, 1986). For an accessible and recent overview of the field, see Simon Horobin, "Mapping the Words," in The Production of Books in England I350-I500, ed. Alexandra Gillespie and Daniel Wakelin (Cambridge: Cambridge University Press, 201I), 59-78.

I6 Samuels, "Langland's Dialect," 240. Cf. A. I. Doyle's similar argument: "What is difficult to conceive is that, if $\mathrm{C}$ had been released by the author in London, or reached it at an early date, no copies of the simple text should survive in other than West or W. Central Midland guise." "Remarks on Surviving Manuscripts of Piers Plowman," in Medieval English Religious and Ethical Literature: Essays in Honour of G. H. Russell, ed. Gregory Kratzmann and James Simpson (Cambridge: D. S. Brewer, I986), 45. 
I7 Pearsall, "Langland's London," in Justice and Kerby-Fulton, Written Work, 198, and New Annotated Edition, 2I, respectively. See above, note 5 on Horobin's essay, and note that two of the five scribes of the $i$-group's manuscripts have now been identified and are indeed based in London: John Marchaunt, based at Guildhall, who copied the Ilchester MS, and Robert Lynford, a member of the Brewers' Company (whose hall was near Guildhall), who copied Oxford, Bodleian MS Digby IO2 (MS Y). See, respectively, Mooney and Stubbs, Scribes and the City, 38-65; and Simon Horobin, "The Scribe of Bodleian Library, MS Digby IO2 and the Circulation of the C Text of Piers Plowman," YLS 24 (2010): 89-II2, and Mooney and Stubbs, I2I-2.

I8 Samuels, "Langland's Dialect," 240. Likewise Horobin, who refers to "the textually superior $i$-group" which contrasts with "the textually inferior $p$ group." "In London and Opelond'," 248.

I9 Andrew Galloway, "The Account Book and the Treasure: Gilbert Maghfeld's Textual Economy and the Poetics of Mercantile Accounting in Ricardian Literature," Studies in the Age of Chancer 33 (20II): 82. This is part of his response to the fact that "the archive and the idea of London can again be central in Ricardian literary scholarship" (68).

20 Brewer, Editing Piers Plowman, 267, quoting Bessie F. Allen, "The Genealogy of the C Text Manuscripts of Piers Plowman," MA thesis, University of London, 1923. Allen's remarks were summarized by F. A. R. Carnegy, An Attempt to Approach the C-Text of Piers the Plowman (London: University of London Press, 1934), who was the authority for Donaldson, The C-Text and Its Poet, 230-I, who in turn is cited by Samuels, "Langland's Dialect" (see note I8). The most prominent advocate of the P-group's "inferiority" is Derek Pearsall, e.g. at Piers Plowman by William Langland: An Edition of the C-Text (York: York Medieval Press, 1978), 20-I. The inherently subjective base of the Langland archive is clear from the fate of the $\mathrm{TH}^{2} \mathrm{Ch}$ group, judged by Allen to be the nearest to Langland, then $i$, then $p$, but now considered the worst of the lot: from II.296-22.379, where the group attests C, Russell and Kane find some 399 errors (The C Version, 38-9).

2I Russell and Kane, The C Version, 176 , where they also note that other MSS or groups (including "superior" ones) added significantly to the damage. MS $\mathrm{P}$ and its genetic twin $\mathrm{E}$ added some 270 , and the $\mathrm{X}$-scribe himself introduced some 323 to the text. See also previous note on $\mathrm{TH}^{2} \mathrm{Ch}$.

22 See Russell and Kane, The $C$ Version, 43-4, 46 for the X-family, and 46-58 for the P-family.

23 See Warner, Lost History, 2-7. On the probability that Langland died before C was released, which I endorse, see Russell and Kane, The C Version, 82-8.

24 Robert Adams, "The Kane-Donaldson Edition of Piers Plowman: Eclecticism's Ultima Thule," Text I6 (2006): I37.

25 Warner, Lost History, 49-6I.

26 John M. Bowers, "Dating Piers Plowman: Testing the Testimony of Usk's Testament," YLS I3 (1999): 65-I00, makes a powerful case against that idea, but A. V. C. Schmidt's defense (Parallel-Text, 276) is not easily dismissed. 
27 James Simpson, “'After Craftes Conseil clotheth yow and fede': Langland and London City Politics," in England in the Fourteenth Century: Proceedings of the I99I Harlaxton Symposium, ed. Nicholas Rogers (Stamford: P. Watkins, I993), IIO; see also the similar claim by Galloway, "Account Book," 82.

28 Caroline Barron, "William Langland: A London Poet," in Chaucer's England: Literature in Historical Context, ed. Barbara Hanawalt (Minneapolis: University of Minnesota Press, I992), 96; cf. OED, s.v. "regratery" with reference to "regrate" (v. [2]), and $M E D$, s.v. "regraterie" (n.).

29 In line IO2 I adopt the JDRMK reading mennes rather than Russell and Kane's men so as to reflect the pronunciation necessary to ensure the single long dip that must occur in the b-verse.

30 This is Batman's annotation in a copy of The Pricking of Love, the English translation of the Stimulus amoris, in Cambridge, Trinity College MS B.I4.I9, fol. $67^{\mathrm{v}}$. I transcribe from the reproduction of the item in Jennifer Summit, Memory's Library: Medieval Books in Early Modern England (Chicago: University of Chicago Press, 2008), II5; see her discussion, II4-I6. On Batman and Piers Plowman, see Simon Horobin, "Stephan Batman and His Manuscripts of Piers Plowman," RES 62 (2011): 358-72.

3I Simpson connects Langland's cataclysmic result of regratery with the chronicler Thomas Walsingham's report that supporters of Northampton held that the whole city would be swallowed up into the earth if the city were not purged of its immoralities, but he is following the critical convention of treating lines 87-II4 as merely an amplification of the B passage's discussion of false trade, so that the London character of the lines is the product of the poet's memory, not experience. "'After Craftes Conseil'," I23-4.

32 On the factional politics of 1380 s London, see especially Ruth Bird, The Turbulent London of Richard II (London: Longmans, Green, I949), 63-IOI, and Pamela Nightingale, A Medieval Mercantile Community: The Grocers' Company and the Politics and Trade of London I0oo-I485 (New Haven: Yale University Press, 1995), 263-9I.

33 My primary source, from which quotations in the next paragraph are taken, is The Westminster Chronicle, I38I-I394, ed. and trans. L. C. Hector and Barbara F. Harvey (Oxford: Clarendon, 1982), 60-5 (see 34-5 on John Mowbray's death); the information about dinner with Waldegrave is from $285-6$.

34 This detail about the length of the severed head's stay comes from Bird, Turbulent London, 8 n.9, citing Ludgate as the site. Bird follows the account of the events of February 7 from the Coram Rege Roll.

35 Russell and Kane discuss their reconstruction of this passage at The $C$ Version, 159.

36 According to the Coram Rege Roll, Northampton was imprisoned in Tintagel, not Corfe, castle (Bird, Turbulent London, 83), but Letter-Book H, like the Westminster Chronicle, records Northampton's destination as Corfe castle (Calendar of Letter-Books ... of the City of London: Letter-Book H, ca. A.D. 1375-1399, ed. Reginald R. Sharpe [London: John Edward Francis, I907], 229). 
37 A. G. Mitchell, "Notes on the C-Text of Piers Plowman," London Medieval Studies I (I948 for 1939): 487. On the figures here discussed, see Brewer, Editing Piers Plowman, 265-7I.

38 Carnegy, Attempt, I2-I3. I have altered the line numbers to accord with modern conventions.

39 Allen, "Genealogy," had recently pointed out that at $\mathrm{C} 3.422$, the $i$-group has a clear instance of a scribal gloss taken up into its text, "That dwelleth in amalek mebles" where the p-group reads just "mebles" (see Carnegy, Attempt, I2-I3). Russell and Kane, The $C$ Version, I4I, classify this among the "many variants attested by $\mathrm{X}$ and its genetic associates ... which appear as scribal derivatives of an alternative because more explicit." See Kane and Donaldson, The B Version, I93 for a discussion of lines in the archetypal text deemed to be "induced by scribal response to the immediate context."

40 Carnegy, Attempt, I3.

4I Mitchell, "Notes," 488. Brewer remarks that in his edition "Mitchell nowhere gives any detailed information on the principles on which he had established his text, apparently assuming ... that these would be unproblematic. Instead he makes merely general comments, as 'In emendation we have sought to be as conservative as possible, without carrying conservation to an unreasonable extreme" (Editing Piers Plowman, 270).

42 Pearsall's 1978 edition is the only one to cite Mitchell, claiming that "the sense [of 'as an ancre'] is good" (Piers Plowman by William Langland, n. to C 3.I40). This disappears from $A$ New Annotated Edition; Schmidt prints the passage in its $i$-group form; and as we have seen the phrase is retained in the Athlone edition.

43 This list comes from Joseph S. Wittig, Piers Plowman: Concordance (London: Continuum, 200I), s.v. "ancre."

44 See Samuels, "Langland's Dialect," 244.

45 Horobin, "'In London and Opelond'," 263.

46 Mitchell, "Notes," 487-8.

47 Ibid., 488, 487.

48 See Galloway, Penn Commentary, 29, also citing 5.2.

49 Ralph Pugh, Imprisonment in Medieval England (Cambridge: Cambridge University Press, 1968), I8; see also 374-83, and Megan Cassidy-Welch, Imprisonment in the Medieval Religious Imagination, c.IISO-I400 (New York: Palgrave Macmillan, 20II), esp. 36-40.

50 Mary Rotha Clay, The Hermits and Anchorites of England (London: Methuen, I9I4), I42-3. See also Ann K. Warren, Anchorites and Their Patrons in Medieval England (Berkeley: University of California Press, 1985), 79-8I, which refers to the "real prison" in which Matilda was kept (80).

5I Anneke B. Mulder-Bakker, Lives of the Anchoresses: The Rise of the Urban Recluse in Medieval Europe, trans. Myra Heerspink Scholz (Philadelphia: University of Pennsylvania Press, 2005), 69. See Warren, Anchorites and Their Patrons, 93-IOO on the symbolism of the prison.

52 "The solitary vocation was always a choice, an individual embrace of a most difficult choice," says Ann Warren (Anchorites and Their Patrons, IOI-2). This 
"consent" was thus no mere fiction, as Elizabeth Fowler, discussing the Meed episode, has shown marriage to have been. "Civil Death and the Maiden: Agency and the Conditions of Contract in Piers Plowman," Speculum 70 (1995): 760-92.

53 Mulder-Bakker, Lives of the Anchoresses, I45.

54 Neither Russell and Kane, The C Version, nor Schmidt, Parallel-Text, collates $\mathrm{N}^{2}$ s $\mathrm{C}$ material conflated into its A portion.

55 See Warner, Lost History, esp. 28-9, 3I, 46-7, 57-8.

56 Mitchell uses this term at "Notes," 488.

57 See Russell and Kane, The $C$ Version, 87-8, and Duggan, "Notes on the Metre," which argues that Langland was much looser regarding alliterative conventions, especially in the $\mathrm{C}$ version, than anyone (including Duggan) has been willing to grant.

58 Skeat, Parallel Texts, 2: 45; see Carnegy's objection to this (Attempt, I3). Galloway notes that there was widespread belief "that Edward II was not only incarcerated in Corfe but brutally murdered there"; see discussion in Penn Commentary, 307.

59 Donaldson, C-Text and Its Poet, I29. See also, e.g., Barron, "A London Poet," 96-7, I07 n.35; Pearsall, "Langland's London," I88-9.

60 Simpson, "'After Craftes Conseil'," I24 (tensions of 1376 ). In this essay he does not refer to Langland's uplandish location, but this assumption must explain why Simpson does not discuss the $\mathrm{C}$ nature of 3.87-II4. He had earlier, like everyone else, claimed to find it "probable, from the dialectal evidence of the C manuscripts, that [Langland] moved back to Malvern in later life" (Piers Plowman: An Introduction to the B-Text [New York: Longman, I990], 4).

6I Simpson, "After Craftes Conseil'," I27.

62 See Warner, Lost History, 49-6I.

63 Piers Plowman: The Prologue and Passus I-VII of the B text as Found in Bodleian MS. Laud 581, ed. J. A. W. Bennett (Oxford: Clarendon, I972), I36 (n. to B 3.76-86).

64 Pearsall, New Annotated Edition, 83, n. to 3.77-II4. See Russell and Kane, The $C$ Version, 86, for a plausible account of the material circumstances that would have brought about the repetition in lines 77 and II5; also, Galloway, Penn Commentary, 298-304.

65 See Russell and Kane, The C Version, 62-88, and summary at 89.

66 Carnegy, Attempt, I3; see also C. David Benson and Lynne Blanchfield, The Manuscripts of Piers Plowman: The B Version (Cambridge: D. S. Brewer, I997), 2I.

\section{Latinitas et communitas}

I For representative overviews, see Siân Echard, "With Carmen's Help: Latin Authorities in the Confessio Amantis," Studies in Philology 95 (1998): I-40; Graham D. Caie, "The Significance of the Early Chaucer Manuscript Glosses (with Special Reference to the Wife of Bath's Prologue)," Chaucer Review Io (1976): 350-60. 
2 Sarah Stanbury, "Vernacular Nostalgia and The Cambridge History of Medieval English Literature," Texas Studies in Literature and Language 44 (2002): 96.

3 Fiona Somerset, "Al pe comonys with o voys atonys': Multilingual Latin and Vernacular Voice in Piers Plowman," YLS I9 (2005): III.

4 Kane, The A Version, I67. They instead have, of course, the number of the preceding English line followed by the Greek letter alpha (or beta, etc.).

5 See Kane and Donaldson, The B Version, and Russell and Kane, The C Version.

6 See Kane, The A Version, 45-50; Kane and Donaldson, The B Version, 22I-4; Russell and Kane, The $C$ Version I83-5; and, for the two Latin quotations added to Huntington MS Hm II4, not included in any of those editions, George H. Russell and Venetia Nathan, "A Piers Plowman Manuscript in the Huntington Library," Huntington Library Quarterly 26 (1963): I27-8.

7 John A. Alford, Piers Plowman: A Guide to the Quotations (Binghamton, N.Y.: Medieval and Renaissance Texts and Studies, 1992), 9.

8 Butterfield, Familiar Enemy, xxiv. See, e.g., Tim William Machan's claim, based on his study of its code-switching (i.e., passages in which the Latin and English intermingle; a focus, again, on the extraordinary): "It is not that English was still completely subservient to Latin or even incipiently contentious with it but that Latin was already yielding to the vernacular." "Language Contact in Piers Plowman," Speculum 69 (1994): 380.

9 Butterfield, Familiar Enemy, xxiv.

IO The Vision of William, concerning Piers Plowman: The "Vernon" Text; or Text A, ed. Walter W. Skeat, EETS o.s. 28 (London: Trübner, I867), xxi-xxii. The only other notice of the existence, if not the contents, of this item is MarieClaire Uhart, "The Early Reception of Piers Plowman" (Ph.D. dissertation, University of Leicester, I986), 240: “Explicit: 'Amen, Amen,' followed by I2 lines, mostly illegible, one of which reads: 'primus passus de vision passus secundus de dowell." It is not mentioned in W. H. Black, A Descriptive, Analytical and Critical Catalogue of the Manuscripts Bequeathed unto the University of Oxford by Elias Ashmole Esq. (Oxford, I845), col. I277, or Kane, The $A$ Version, I-2.

II See Jane Roberts, A Guide to Scripts used in English Writings up to I50o (London: British Library, 2005), 2II-I3. The distinctive Secretary features are its angularity, the horns found on the heads of the letter $g$, and the neat, pointed, single-compartment $a$. A few anglicana alternatives are the $r$ with a slight descender and the sigma-shaped $s$.

I2 These are (relying on Alford, Guide to the Quotations): line I, II.I93 $\alpha$, "Rejoice with them that rejoice; weep with them that weep" (Rom. I2:I5; quotations are from the Douay Rheims translation); line 2, 3.233 $\alpha$, "Amen amen I say to you" (Matt. 6:2); line 3, II.I96 $\alpha$, "he that shall do and teach, he shall be called great in the kingdom of heaven" (Matt. 5:I9); line 5, IO.I200, "every one that exalteth himself, shall be humbled: and he that humbleth himself, shall be exalted" (Luke I8:I4); line 7, II.263 $\alpha$, "And no man hath ascended into heaven, but he that descended from heaven" (John 3:I3); line 8, I0.98, "If you live rightly you will not worry about words of evil" (Cato, Distich 3.2); line 9, 7.68 $\alpha$, "And 
with the just let them not be written" (Psalm 68:29); 7.78, "In the name of God Amen" (the usual formula for beginning of a will); line Io (first part), II.255, "Revenge is mine, I will repay, saith the Lord" (Rom. I2:I9); line I2, I0.4Ia, "Let us make man to our image" (Gen. I:26); line I3, same as line 8.

I3 See C. W. Dutschke with the assistance of R. H. Rouse et al., Guide to Medieval and Renaissance Manuscripts in the Huntington Library (San Marino: Huntington Library, 1989), at I37, http://sunsite.berkeley.edu/hehweb/ HMi37.html. Fifteenth-century schoolboys inscribed it three times in a thirteenth-century schooltext intended to teach Latin: University of Nottingham Library, MS Mi LM 2, fols. $126^{\mathrm{v}}$ (twice) and $142^{\mathrm{v}}$. See The Wollaton Medieval Manuscripts: Texts, Owners and Readers, ed. Ralph Hanna and Thorlac Turville-Petre (York: York Medieval Press, 20IO), I4, III.

I4 On this item see Hans Walther, Proverbia Sententiaeque Latinitatis Medii Aevi, 5 vols. (Göttingen: Vandenhoeck und Ruprecht, 1963-7), 594a, "In his versibus totum est ABC."

I5 In the hand of William Holyngborne, chaplain of the abbot of St. Augustine's without Canterbury. See Kane, The A Version, 7 and n.I.

I6 Derrida, Archive Fever, 40.

I7 See especially Robert Adams, "The Reliability of the Rubrics in the B-Text of Piers Plowman," ME 54 (1985): 208-3I. Kane's description of the manuscripts in The A Version includes the rubrics (pp. I-2 for Ashmole I468), but they disappear from the $\mathrm{B}$ and $\mathrm{C}$ editions. Schmidt has a helpful treatment: Parallel-Text, Appendix II, "The Rubrics," 938-42.

I8 Especially Lawrence M. Clopper, "Langland's Markings for the Structure of Piers Plowman," MP 85 (1988): 245-55, and J. A. Burrow, "The Structure of Piers Plowman B xv-xx: Evidence from the Rubrics," MAE 77 (2008): 306-I2.

I9 Burrow, "Structure," 3II.

20 Judith A. Jefferson dates the manuscript to between 1514 and I544, tending toward the latter. "Divisions, Collaboration and Other Topics: The Table of Contents in Cambridge, University Library, MS Gg.4.3I," in Burrow and Duggan, Medieval Alliterative Poetry, I40.

2I Ibid., I44.

22 John A. Alford, "The Role of the Quotations in Piers Plowman," Speculum 52 (1977): 96, 80.

23 Ibid., 99.

24 Somerset, "Multilingual Latin," Io9.

25 Traugott Lawler, "Langland Versificator," YLS 25 (20II): 62-3.

26 Derrida, Archive Fever, 40.

27 Schmidt, Parallel-Text, 656, n. to C I7.220; I standardize abbreviations.

28 Traugott Lawler, "William Langland," in The Oxford History of Literary Translation in English, Vol. I: To I550, ed. Roger Ellis (Oxford: Oxford University Press, 2008), I56, I54.

29 On this concept in the poem see John A. Burrow, "God and the Fullness of Time in Piers Plowman," MAE 79 (2010): 300-5. 
30 For a few of the many other instances see Walter W. Skeat, "Age of the World II," N\&Q 4th ser. 3 (I869): 203, and Cambridge, Trinity College MS R.I4.9, fol. $2^{\mathrm{r}}$ (see M. R. James, The Western Manuscripts in the Library of Trinity College, Cambridge: A Descriptive Catalogue, 4 vols. [Cambridge: Cambridge University Press, 1900-4], 2:29I-2).

3I These images are accessible in The Piers Plowman Electronic Archive, Vol. 3: Oxford, Oriel College MS $79(O)$, ed. Katherine Heinrichs (Woodbridge: Boydell and Brewer for the Medieval Academy of America and SEENET, 2004), which is my source.

32 MS O's defective status "and the fact that $\mathrm{C}^{2}$ is the later manuscript might suggest that $\mathrm{C}^{2}$ was copied from $\mathrm{O}$ to 17.98," say Kane and Donaldson: "But the existence of some 30 unoriginal readings peculiar to $\mathrm{O}$ makes this seem unlikely. For if $\mathrm{C}^{2}$ were a copy of $\mathrm{O}$ they would presuppose a corrector of $\mathrm{C}^{2}$ more intelligent than the character of that manuscript otherwise leads one to expect." The B Version, 24 n.23.

33 See Stephen Partridge, "Designing the Page," in Gillespie and Wakelin, Production of Books, 82. An image of one of the Chaucer examples, B.L. MS Harley I239, fol. $82^{\mathrm{r}}$ (Man of Law's Tale), is on 83 . An early modern reader has bracketed the two Latin quotations, glossing them: "This is not in ye Printed Ed:" and "nor this."

34 Alford, "Role of the Quotations," 86.

35 Ibid., 87.

36 Helen Barr, "The Use of Latin Quotations in Piers Plowman with Special Reference to Passus XviII of the 'B' Text," Ne'Q n.s. 33 (1986): 443.

37 Alford, Guide to the Quotations, 29-30.

38 Walter W. Skeat, "Quotations Wanted," NEQ 3rd ser. Io (I866): 290-I.

39 For the identification see John A. Alford, "More Unidentified Quotations in Piers Plowman," MP 8I (1984): 279, and Guide to the Quotations, 6I; on this passage as evidence for Higden's prominence see Andrew Galloway, "Latin England," in Imagining a Medieval English Nation, ed. Kathy Lavezzo (Minneapolis: University of Minneapolis Press, 2004), 70-I.

40 This is the loose translation by Griet Galle, ed., Peter of Auvergne: Questions on Aristotle's De Caelo: A Critical Edition with an Interpretative Essay (Leuven: Leuven University Press, 2003), 207*, in his discussion of the question, 4.I.2.2. The question is II, I8 (200). On the structure of the questions see IV.I.2 $\left(90^{*}-92^{*}\right)$, which explains why our item does not express Peter's own belief.

4I Galle, Peter of Auvergne, Liber II, quaestio I8, item 2 (200). My translation, based on Galle's discussion, 4.I.2.2 (207*).

42 This is Galle's summary, Peter of Auvergne, 4.I.2.2 (207*), of Peter's solution, 2OI.

43 Michael Calabrese, "Prostitutes in the C-Text of Piers Plowman," JEGP Ios (2006): 284. Translation from Pearsall, New Annotated Edition.

44 Calabrese, "Prostitutes," 285.

45 Walther, Proverbia Sententiaeque, no. 22348; also his Initia carminum ac versum Medii Aevui posterioris Latinorum (Göttingen: Vandenhoeck und Ruprecht, 
1969), no. I4533. Neither of these includes its appearance amid a series of fifteenth-century additions to the closing flyleaves of a register of St. Alban's abbey (Oxford, Bodleian MS Rawlinson B 332: Chronica Monasterii S. Albani: Registra Quorundam Abbatum Monasterii S. Albani, Vol. 2: Registra Johannis Whethamstede, Willelmi Albon, et Willelmi Walingforde, ed. Henry Thomas Riley [London, I873], 297). The anticlericalism here replaced the chauvinism of other fourteenth-century instances: "Parisius nati non possunt beati / sunt infelices, quia matres sunt meretrices" (Walther, Proverbia, no. 20716).

46 Sanford B. Meech, "A Collection of Proverbs in Rawlinson MS D 328," MP 38 (1940): I24; this is one of Walther's items; also Bartlett Jere Whiting, with the collaboration of Helen Wescott Whiting, Proverbs, Sentences, and Proverbial Phrases from English Writings Mainly before Isoo (Cambridge, Mass.: Harvard University Press, 1969), P399.

47 Consulted in William Langland's The Vision of Piers Plowman: The C-Text: A Facsimile of Huntington Library, San Marino, MS Hm I43, ed. Tomonori Matsushita (Tokyo: Senshu University Press, 20Io).

48 Schmidt, Parallel-Text, 6I6; cf. Christopher Cannon, "Langland's Ars Grammatica," YLS 22 (2008): I-25, and especially Lawler, "Langland Versificator." The translation is from Pearsall, New Annotated Edition.

49 Stella Pates relates her discovery on a webpage for a book in which she advances the claim that John Grandisson wrote the poem: "A New Discovery: Piers Plowman and Manuscript Bodley 463," www.piersplowman.com/piersplowman_discovery.htm.

50 Dante Alighieri, Dante Alighieri: De Situ et Forma Aque et Terre, ed. Giorgio Padoan (Florence: Le Monnier, 1968), 21.72; Constantine of Pisa, Constantine of Pisa, The Book of the Secrets of Alchemy: Introduction, Critical Edition, Translation and Commentary, ed. Barbara Obrist Leiden (New York: Brill, I990), 77. My thanks to David Juste for illuminating discussion of this material.

5I Barney, Penn Commentary, II8, on C.2I.96-I07, a passage on Jesus as conqueror.

52 Alford, Guide, 84. Anna P. Baldwin claimed to have identified an instance in the plural in The Testament of Job (endorsed by Schmidt, Parallel-Text, 629), but that text is in Greek, not Latin, and achieved minimal circulation in medieval Europe. "The Triumph of Patience in Julian of Norwich and Langland," in Langland, the Mystics and the Medieval English Religious Tradition: Essays in Honour of S. S. Hussey, ed. Helen Phillips (Cambridge: D. S. Brewer, I990), 7I-83, especially 72, 8I.

53 B.L. MS Royal 7 E IV, fol. $237^{\mathrm{r}}$; translation mine. This is chapter 29 , s.v. "humilitas."

54 Alford, "Role of the Quotations," 99; he is focusing on passus I4. "The possibility that Langland was influenced by Bromyard is improved by recent scholarship" that dates the Summa to c.1348-50 (99, n.60).

55 Cannon, "Langland's Ars Grammatica," esp. 24-5; Lawler, "Langland Versificator." Alford, too, emphasizes the pervasiveness of this mode of influence upon Langland (Guide, 24-7). 
56 Cannon, "Langland's Ars Grammatica," 17; A. C. Spearing, "The Art of Preaching and Piers Plowman," in his Criticism and Medieval Poetry (London: Edward Arnold, 1964), 84-5 on digression, 88-9 on repetition.

57 These are from Oxford, Bodleian MS Bodley 649, fols. $9 \mathrm{I}^{\mathrm{r}}$ and $43^{\mathrm{v}}$ respectively. See Siegfried Wenzel, Macaronic Sermons: Bilingualism and Preaching in Late-Medieval England (Ann Arbor: University of Michigan Press, 1994), 89.

58 E.g., Siegfried Wenzel, Latin Sermon Collections from Later Medieval England (Cambridge: Cambridge University Press, 2005), I53 n.IO, 218, and 326.

59 Barry Taylor, "Medieval Proverb Collections: The West European Tradition," Journal of the Warburg and Courtauld Institutes 55 (1992): 33; see discussion, 33-4.

60 Wenzel, Latin Sermon Collections, 321, 322.

6I On the former, see Grindley, "A New Fragment"; on the latter, see Scase, "Dauy Dycars Dreame," 186-7. Note also the excerpt of A 4.I5-17 discussed in the Introduction.

62 A. G. Rigg, "MS Bodley 85I," in Piers Plowman: A Facsimile of the Z-Text, 4I. Rigg identifies the line as B I.I88, noting its unique brennit for received worth cheyned, but in all B MSS the line begins with Forthi, while in the Piers text of Bodley 85I itself the line begins Suche (fol. $126^{\mathrm{v}}$; Z I.II7 in Rigg and Brewer), so its origins are probably in $\mathrm{A}$ or $\mathrm{C}$, which begin Chastite - though Dodsthorp himself might have encountered it via oral transmission. For additional evidence that readers loved the aphoristic lines of English poetry represented here see Alison Wiggins, "What Did Renaissance Readers Write in their Printed Copies of Chaucer?" The Library 7th ser. 9 (2008): 3-36.

63 Rigg, "MS Bodley 851," 38.

64 See George H. Russell, "'As they read it': Some Notes on Early Responses to the C-Version of Piers Plowman," Leeds Studies in English n.s. 20 (1989): I8I-6. A full discussion is now Simon Horobin, "John Cok and His Copy of Piers Plowman," YLS 27 (2013): forthcoming, which I read after having written this section.

65 See Russell, "'As they read it'," 186, on the "extraordinarily high proportion" of errors Cok's text shares with this copy, which are identified in Russell and Kane, The C Version, apparatus for 16.82-198. It is of course possible that Cok consulted a now-lost manuscript closely related to MS F, but easier to believe it was $\mathrm{F}$ itself.

66 See Ralph Hanna, The English Manuscripts of Richard Rolle: A Descriptive Catalogue (Exeter: University of Exeter Press, 20IO), 7. See also Horobin, "John Cok," and Ryan Perry's description of the manuscript for the webpage of Geographies of Orthodoxy: Mapping English Pseudo-Bonaventuran Lives of Christ, I350-I550, www.qub.ac.uk/geographies-of-orthodoxy/resources/? section=manuscript\&id=I3, revision date June I, 2oro.

67 On Langbaine's, in Bodleian MS Wood donat. 7, see A. S. G. Edwards, "Piers Plowman in the Seventeenth Century: Gerard Langbaine's Notes," YLS 6 (I992): I4I-4; for James's, see Simon Horobin, "Richard James and the Seventeenth-Century Provenance of British Library MS Cotton Caligula 
A.XI," Journal of the Early Book Society I3 (2010): 249-54. See Introduction above.

68 The great bulk of the items, eighteen, come from passus IO-I4. Most are proverbs, with the balance comprising patristic, biblical, and legal tags. They are, in the order of their appearance on the page: I.I4I $\alpha / 5.440 \alpha, 5.269 \alpha-\beta$,

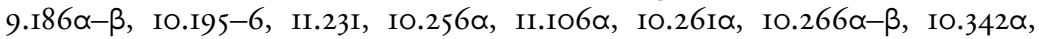
II. $58 \alpha$, II.269 $\alpha$, II.28I $\alpha$, II. $4 \mathrm{I} 6 \alpha$, I2.5O $\alpha$, I2.65 $\alpha$, I2.207 $\alpha, \mathrm{I} 3.45 \alpha, \mathrm{I} 3.426 \alpha$, I4.60 $\alpha, \mathrm{I} 4.276, \mathrm{I} 5.39 \alpha, \mathrm{I} 5.343 \alpha$, I7.34I $\alpha$. The eighteen items from passus IO-I4 make for roughly I5 percent of the Latin available for citing there; the remaining quotations amount to about 3.6 percent of the available items from those passus. I am grateful to Ian Cornelius for examining the Yale Crowley and Rogers editions, alerting me to this item, and arranging for an image on my behalf.

69 Joanne Rice, in The Riverside Chaucer, 896-7, citing Egerton 2864's gloss pacientes vincunt, "which appears in Piers Plowman B 13.135 and I4.33," together with other instances of the proverb in the singular (including, in English, Troilus and Criseyde 4.I484).

\section{4 “Quod piers plowman”}

I Anne Hudson, "Epilogue: The Legacy of Piers Plowman," in Alford, A Companion to Piers Plowman, 260, a view based in the main upon the Lollardesque works of some of the Piers Plowman tradition and the reformist pamphlets of the sixteenth century. See, e.g., Kelen, Langland's Early Modern Identities, 43-76.

2 Quotations of The Vision of Pierce Plowman, now fyrste imprinted by Roberte Crowley ... (London, $\mathrm{I550} ;=\mathrm{Cr}^{\mathrm{I}}$ ) are from the Lehigh University Library copy, available online at http://digital.lib.lehigh.edu/cdm4/eb_viewer.php? ptr $=1027$.

3 John N. King, English Reformation Literature: The Tudor Origins of the Protestant Tradition (Princeton: Princeton University Press, 1982), 322.

4 John E. Paul, "Hampshire Recusants in the Time of Elizabeth I, with Special Reference to Winchester," Proceedings of the Hampshire Field Club 2I (1959): 63, quoted by Edward Wilson, The Winchester Anthology: A Facsimile of British Library Additional Manuscript 60577 with an Introduction and List of Contents by Edward Wilson and an Account of the Music by Iain Fenlon (Cambridge: D. S. Brewer, I98I), II.

5 On the date and place of production, see The Winchester Anthology, 8-io (on fol. $107^{\mathrm{v}}$ the main scribe added a colophon with the date 1487 ); on the contents see I4-I6 and updates by Wilson in NoQ: "A Newly Identified Middle English Lyric in 'The Winchester Anthology'," n.s. 45 (1998): 430; "A Middle English Verse Sermon in the Winchester Anthology," n.s. 46 (1999): 17-20; and "A Newly Identified Copy of The ABC of Aristotle in "The Winchester Anthology'," n.s. 47 (2000): 296. A digital facsimile of the entire MS is now available at www.bl.uk/catalogues/illuminatedmanuscripts/ > 60577 . 
6 Andrew G. Watson, "A Sixteenth-Century Collector: Thomas Dackomb, I496-c.1572," The Library sth ser. I8 (1963): 206. On Dackomb's books see also Wilson, The Winchester Anthology, I2 n.22, which lists three more manuscripts Watson subsequently identified as having been owned by Dackomb. On the manuscript's owners, see Wilson, The Winchester Anthology, IO-I3.

7 This item has never appeared in any lists of witnesses or in any studies of the sixteenth-century reception or production of Piers Plowman. To date its existence has been noted only in the list of contents of The Winchester Anthology, 35; Derek Pearsall, review of the facsimile, NeQ n.s. 30 (1983): 164; Helen Cooper, review of the facsimile, RES n.s. 35 (1984): 355; William A. Ringler, Jr., Bibliography and Index of English Verse in Manuscript I50I-I558, prepared and completed by Michael Rudick and Susan J. Ringler (London: Mansell, 1992), TM 753 (entry for "In a someres seyson"); and A. S. G. Edwards, "The Blage Manuscript and Alliterative Verse in the Sixteenth Century," in Burrow and Duggan, Medieval Alliterative Poetry, 83 n.19.

8 See The Winchester Anthology, 4-5 on the hands of the manuscript.

9 Pearsall, review of The Winchester Anthology, 164, because the Winchester passage reads "thre" for received "two" (corrected later); substitutes line 325 for 329 , and in that line reorders "flodes and foule wedres fruytes shal faille"; uniquely attests "bere rule \& reigne" (328) as against "have pe maistrie"; and adds the unique afterthought "of pe erth" (329), as well as "Except" for "But if."

IO For the process in a much different context see, e.g., G. W. Ahlström, "Oral and Written Transmission: Some Considerations," Harvard Theological Review 59 (1966): 69-8I.

II See Benson and Blanchfield, Manuscripts, 167-8, 190, 264; also Christine Schott, Marginalia of Piers Plowman, www.rarebookschool.org/fellowships/ rbs-uva/plowman6.html.

I2 Kathryn Kerby-Fulton, Reformist Apocalypticism and Piers Plowman (Cambridge: Cambridge University Press, 1990), 2.

I3 Lines 1724 and 1726, from The Piers Plowman Tradition, ed. Helen Barr (London: J. M. Dent, 1993). Helen Barr says these lines represent "the characteristic language of prophecies": Signes and Sothe: Language in the Piers Plowman Tradition (Cambridge: D. S. Brewer, 1994), 25 n.I4.

I4 Letters and Papers, Foreign and Domestic, of the Reign of Henry VIII, Vol. I2 (I), ed. James Gairdner (London: HM Stationery Office, I890), no. 534; also no. IO23. The similarities to Piers Plowman were first noted by Madeleine Hope Dodds, "Political Prophecies in the Reign of Henry VIII," Modern Language Review II (1916): 282-3. On such "painted prophecy," see Keith Thomas, Religion and the Decline of Magic: Studies in Popular Beliefs in Sixteenth- and Seventeenth-Century England (London: Weidenfeld and Nicolson, 1972), 390.

I5 Thomas, Religion, 398, 399. See Thomas's whole chapter (389-432), and Sharon L. Jansen, Political Protest and Prophecy under Henry VIII (Woodbridge: Boydell, I99I).

I6 Thomas, Religion, 40I. 
I7 Ibid., 400-I, citing Gairdner, Letters and Papers, no. I2I2.

I8 Wendy Scase, "Writing and the Plowman: Langland and Literacy," YLS 9 (1995): I27; see also Benson, Public Piers Plowman, 62.

I9 See Hanna, London Literature, 25I-2; Galloway, Penn Commentary, I34; and Traugott Lawler, "Langland Translating," in Answerable Style: The Idea of the Literary in Medieval England, ed. Andrew Galloway and Frank Grady (Columbus: Ohio State University Press, 2013), 59-60.

20 For instance, the Winchester extract attests the "distinctive curly ' $z$ ' form" of the letter " $\mathrm{r}$ " that Benson and Blanchfield identify in the "Sion College" copy of Piers Plowman B, now Tokyo, Toshiyuki Takamiya MS 23 (sigil S), produced $c .1550$ (Manuscripts, II4; see the facsimile of fol. $66^{\mathrm{r}}$ on II2). Ralph Hanna has suggested to me that the hand dates to after 1530, as evidenced by the use of "ar" for Middle English "er."

2I On Buriton's career, see Joan Greatrex, Biographical Register of the English Cathedral Priories of the Province of Canterbury, c.I066-I540 (Oxford: Clarendon, 1997), 678-9.

22 The Winchester Anthology, I0, and notes I4, I5. On Brynstan's career, including his final appearance at St. Swithun's as noted in the next paragraph, see Greatrex, Biographical Register, 678.

23 Gairdner, Letters and Papers, Vol. IO (I887), no. 318; The Winchester Anthology, Iо.

24 On sixteenth-century Plowman texts' engagement with the discourses of "antiquity" and "newfangledness," see Kelen, Langland's Early Modern Identities, 52-8.

25 E.g., Francis Aidan Gasquet, The Last Abbot of Glastonbury and His Companions: An Historical Sketch (London: S. Marshall, Hamilton, Kent, I895), 72-3.

26 Gairdner, Letters and Papers, Vol. IO, no. 318; quoted in The Winchester Anthology, II.

27 The Winchester Anthology, II. It seems more likely to me that Buriton is smarting over his former confrere's abandonment of St. Swithun's for the fraternal life at this difficult moment in the church's life. For such a context see Arnold Williams, "Relations between the Mendicant Friars and the Secular Clergy in England in the Later Fourteenth Century," Annuale Mediaevale I (1960): 22-95.

28 Richard Rex, "Blessed Adrian Fortescue: A Martyr without a Cause?" Analecta Bollandiana II5 (1997): 350; see 325-9 on the missal. Fortescue is the scribe of Bodleian MS Digby I45, dated 1532 in his hand, on which see Thorlac Turville-Petre, "Sir Adrian Fortescue and his Copy of Piers Plowman," YLS I4 (2000): $29-48$ (43-4 on the missal).

29 This is Piers Plowman B I0.322-5 as transcribed by Bryan P. Davis, "The Prophecies of Piers Plowman in C.U.L. MS Gg.4.3I," Journal of the Early Book Society 5 (2002): 34, from fol. $42^{\mathrm{v}}$ of that sixteenth-century manuscript.

30 B I9.470-4, C.U.L. MS Gg.4.3I, fol $95^{\mathrm{v}}$, my transcription of the facsimile of this folio in Benson and Blanchfield, Manuscripts, 40; see also Davis, "Prophecies," 35. 
3I The C text in BL Additional MS 34779 is supplied with B 6.327-9 in the margin after misplaced C 8.348: see Russell and Kane, The C Version, I82. And the annotator of the A-text copy Cambridge, Trinity College MS R.3.I4, probably Stephan Batman, Archbishop Parker's chaplain and owner of another Piers Plowman manuscript, glosses the end of passus 7: "Here is left oute v versis which is in the olde coppi \& ar set be nethe," adding them below (fol. $20^{\mathrm{V}}$ ). See Kane, The A Version, 38 n.I, and now, reprinting Kane's comments alongside a facsimile of the inscription, William Langland's The Vision of Piers Plowman: The A-Text: A Facsimile of Trinity College, Cambridge MS R.3.I4, ed. Tomonori Matsushita (Tokyo: Senshu University Press, 20Io), vii. See also Horobin, "Stephan Batman," 362-3.

32 Benson and Blanchfield, Manuscripts, 2I.

33 The title "The Prophecies of Piers Plowman" appears on the frontleaf (ii"). On the treatment of prophecies in this MS see Benson and Blanchfield, Manuscripts, 40-3, I29-36; Davis, "Prophecies"; and Jefferson, "Divisions, Collaboration," I47-50.

34 Wendy Scase argues against the dating of the tract to 1552, proposing "the likelihood ... that the Dreame dates between February and September 1547": "Dauy Dycars Dreame," 192. Davy Dycars Dreame survives in a single copy, in the Society of Antiquaries. A transcription is in the Early English Books Online Text Creation Partnership, http://quod.lib.umich.edu/e/ eebo/Ar8727.0001.0or/I:r? rgn=divi;view=fulltext.

35 See Scase, "Dauy Dycars Dreame," 177-9.

36 For the assumption that this copyist purposely combined two passages from Langland's poem see Sharon L. Jansen, "Politics, Protest, and a New Piers Plowman Fragment: The Voice of the Past in Tudor England," RES n.s. 40 (1989): 94-5, and Barr, Signes and Sothe, I3.

37 Jansen, "Politics, Protest," 94, attributes these variants to carelessness. See above, note 9 .

38 Scase, "Dauy Dycars Dreame," I84.

39 Sharon L. Jansen [Jaech] mentions this aspect of the collection in an essay published before she recognized the Piers Plowman content of the second item: "British Library MS Sloane 2578 and Popular Unrest in England, 1554-1556," Manuscripta 29 (1985): 32, but mistakes the two "22.a"s for "nota"s in her discussion of the Piers Plowman excerpt ("Politics, Protest," 94, apparatus to her transcription).

40 The item also appears in Bodleian MS Arch. Selden B 8, fol. $268^{\mathrm{r}}$ (six-stanza form) and Bodleian MS Rawlinson C 813, fols. $153^{\mathrm{V}}-54^{\mathrm{r}}$, which gives stanza I as a standalone quatrain followed by "finis," followed by stanzas 5 and 3 run together into four lines (Davy the Dykar), 4 as a quatrain (abbot of Abingdon), and another "finis." Jansen [Jaech], "British Library MS Sloane 2578," 40-I notes the similarities among the Sloane, Arch. Selden, and Harley MSS (first appearance). See also Ringler, Bibliography and Index, TM 1858 ("When father blythe"), citing Harley 559 (first instance) and Arch. Selden B 8, and First-Line Index of English Poetry I500-I800 in Manuscripts of the Bodleian Library Oxford, Vol. 2, ed. Margaret Crum (Oxford: Clarendon, 1969), WIO2I, citing Rawl C 813. 
4I Both Crowley's logic and attention span failed him, as noted by, among others, Brewer, Editing Piers Plowman, I4.

42 This gloss is identical in both the second and third editions, and is found on sig. I.iv $^{\mathrm{r}}$ in both. See The Vision of Pierce Plowman, now the seconde time imprinted by Roberte Crowley ... (London, I550), which is the second edition $\left(\mathrm{Cr}^{2}\right)$, available online in the form of Lehigh University Library 828.I L256p 550a, http://digital.lib.lehigh.edu/cdm4/eb_viewer.php?ptr=770 (select "Passus 6, 7. Fol. xxxvi" from the drop-down menu); and The Vision of Pierce Plowman, nowe the seconde tyme imprinted by Roberte Crowlye ... (London, I550), the third edition $\left(\mathrm{Cr}^{3}\right)$, available in the form of University of California at San Diego Library PR2oro.C76 I550, where the relevant page is http://hdl. handle.net/2027/ucI.31822038I99956? urlappend=\%3Bseq=II9. On the order of the second and third editions, which is commonly confused, see Hailey, "Robert Crowley and the Editing of Piers Plowman," I43-4 n.2.

43 Larry Scanlon, "Langland, Apocalypse and the Early Modern Editor," in Reading the Medieval in Early Modern England, ed. Gordon McMullan and David Matthews (Cambridge: Cambridge University Press, 2007), 59. The foundational discussion, starting from Crowley's distinction between "prophecy" and "truth" in his marginal glosses rather than this preface, is King, English Reformation Literature, 335-6.

44 Mike Rodman Jones proposes that Crowley's nervousness responded to "the impact that prophecy, and apparently verse prophecy, had had within a few months on the largest and most threatening mass civil revolt since I38I," that is, Kett's Rebellion: "'This is no prophecy': Robert Crowley, Piers Plowman, and Kett's Rebellion," Sixteenth Century Journal 42 (201I): 55. Crowley did write about that event in I559's An Epitome of Chronicles (see Jones, 52-3), but there is no evidence for any direct connection between his Piers Plowman editions and the rebellion apart from the accident of timing (I549, I550), given that, as Jones acknowledges, "Langland's prophetic passages are different in tenor, as well as in verse form, from those of the Dussindale rebels" (55).

45 James Simpson, Reform and Cultural Revolution, I350-I547, Vol. 2 of The Oxford English Literary History, gen. ed. Jonathan Bate (Oxford: Oxford University Press, 2002), 332, who points out that "King's arguments ... are overstated" (n.2I); indeed King never refers to Crowley's advice not to read the poem as prophetic.

46 Thomas A. Prendergast, "The Work of Robert Langland," in Renaissance Retrospections: Tudor Views of the Middle Ages, ed. Sarah A. Kelen (Kalamazoo, Mich.: Medieval Institute, 2013), 82, 84, quoting John Harvey, $A$ discoursive probleme concerning prophesies (London: Richard Watkins, 1588), 66. Richard Harvey's copy of Piers Plowman is now Beinecke Id L26 550F.

47 King, English Reformation Literature, 323; also, e.g., Kelen: "The reception of Piers Plowman played no small part in the reinterpretation of England's religious past as proto-Protestant rather than (more accurately, but less usefully) Catholic" (Langland's Early Modern Identities, 75). 
48 Jansen characterizes the "particular variations of the Sloane lines" as "suggestive of Crowley's 1550 printed edition," but goes on to identify BL Additional MS 35287, the only other to feature the readings wurke and fall, as closer ("Politics, Protest," 94). But the two agreements with that copy are easily attributable to convergent variation: wurke manifests the error of "'attraction' to the whole or part of an adjacent or nearby word in the line being copied" (Kane, The A Version, I2I), in this case, workmen, and failel falle confusion is straightforward, occurring as well at, e.g., B 3.347, I5.432, C 3.350 in various manuscripts. The two "suggestive" variations Jansen cites in common with $\mathrm{Cr}$ are Davy ... shall dye (6.330) and religious (I0.322). Yet Davie is the reading of the Winchester excerpt, the title of Churchyard's broadside, and $\mathrm{Cr}^{23}\left(\mathrm{Cr}^{\mathrm{I}}\right.$ attests received Dawe); shal die for die appears as well in the three MSS that make up the B sigil (at least one of which, Bo, has sixteenth-century glosses) and in $\mathrm{Hm}$; and religious is the reading of MSS $\mathrm{HmGYOC}^{2} \mathrm{CotF}$. See the apparatuses in Kane and Donaldson, The $B$ Version, and Russell and Kane, The $C$ Version. The post-I550 date of Sloane is secure, since it features a number of texts that refer to Mary's reign: see Jansen [Jaech], "British Library MS Sloane 2578."

$49 \mathrm{Cr}^{3}$, sig. ${ }^{*}{ }^{\mathrm{v}}$. The most likely explanation of this change is that the compositor was anticipating the first term of the C-text passage cited a few lines later ("Three shyppes").

50 Davis, "Prophecies," $2 \mathrm{I}$.

5I As argued by Hailey, "Robert Crowley and the Editing of Piers Plowman," I6I-2. This first consultation is evidenced in a number of $\mathrm{Cr}-\mathrm{G}$ agreements in error, marginal keys to the text, and the marginal annotation "The Abbot of Abyngton" at precisely the same point $\left(\mathrm{Cr}^{\mathrm{I}}\right.$, fol. $\left.5 \mathrm{O}^{\mathrm{v}}\right)$; the second, in a number of $\mathrm{Cr}^{23}-\mathrm{G}$ agreements, one of which occurs at B 6.328, "hight"/ "heyght" (MS F, too, has this reading) as against received "eizte" (see Hailey, I69 n.69), and in the broad similarities (though not extending to verbal parallels; see Jefferson, "Divisions, Collaboration," I45-6 n.23) between MS G's table of contents and the brief "summary" of principal points in $\mathrm{Cr}^{23}$.

52 John Bale, Scriptorum illustrium maioris brytannie ... (Basle, I559), translated in Simpson, Reform and Cultural Revolution, 332. See King, English Reformation Literature, 96-Io0, 324-6.

53 Scanlon, "Langland, Apocalypse," 65-6; also Michael Johnston, "From Edward III to Edward VI: The Vision of Piers Plowman and Early Modern England," Reformation II (2006): 47-78, which provides a full classification of Crowley's glosses, finding “only nine Polemical Response-theological glosses. Far more often, at doctrinally charged moments, Crowley chooses not to offer any marginal guides to the reader" (63, emphasis in original).

54 Hailey, "Robert Crowley and the Editing of Piers Plowman," undermining a long-held conviction.

55 Hudson, "Epilogue," 260, which on the basis of its contents dates it to later than the "I532" that is inscribed in another hand. For an overview of the 
Protestant and Catholic readings of Langland in the sixteenth century, see Bowers, Chaucer and Langland, 216-27 (220 on this work).

56 King, English Reformation Literature, 338. This is now Oxford, Bodleian Douce L 205.

57 Richard K. Emmerson, "'Yernen to rede redels?' Piers Plowman and Prophecy," YLS 7 (1993): 68.

\section{Urry, Burrell, and the pains of John Taylor}

I Thompson, "Bishop Thomas Percy's Contributions to Langland Scholarship," 452.

2 Summit, Memory's Library, 2.

3 See, e, g., Kane and Donaldson, The B Version, I4-15. On Ht's text see most recently Patricia R. Bart, "Intellect, Influence, and Evidence: The Elusive Allure of the Ht Scribe," in Yee? Baw for Bokes: Essays on Medieval Manuscripts and Poetics in Honor of Hoyt N. Duggan, ed. Michael Calabrese and Stephen H. A. Shepherd (Los Angeles: Marymount Institute Press, 2013), 219-43.

4 Mooney and Stubbs, Scribes and the City, 17-37. Writing in ignorance of Mooney and Stubbs, indeed suggesting that her findings "may provide a means of identifying him by name," Bart profiled the scribe perfectly: "the Ht scribe may well have been an East Anglian man of law active in the capital something of a man of influence rather than solely a professional copyist leading an entirely private life" ("Intellect," 239).

5 Dutschke, Guide, at MS Hm II4, http://sunsite.berkeley.edu/hehweb/HMiı. html. Also, the Schoenberg Database of Manuscripts (http://dla.library.upenn. edu/dla/schoenberg/index.html), and the Late Medieval English Scribes database overseen by Linne Mooney, Simon Horobin, and Estelle Stubbs (www.medievalscribes.com).

6 See Kate Harris, "An Augustan Episode in the History of the Collection of Medieval Manuscripts at Longleat House," in The English Medieval Book: Studies in Memory of Jeremy Griffiths, ed. A. S. G. Edwards, Vincent Gillespie, and Ralph Hanna (London: British Library, 2000), 240-4, relying on the Urry material below and Humfrey Wanley's detailed account of the Spelman auction in BL MS Harley 7055, fol. $235^{\mathrm{r}}$ on this manuscript.

7 Timothy Thomas, "Preface," The Works of Geoffrey Chaucer, ed. John Urry (London, I72I), sig. li ${ }^{\mathrm{r}}$. See Harris, "An Augustan Episode," 243.

8 Thomas, first page of the "Preface," with the bracketed matter added in Thomas's hand to the British Library copy of the edition (shelfmark 643 . m.4). On Christ Church's use of the edition for fund-raising, see Sarah A. Kelen, "Cultural Capital: Selling Chaucer's Works, Building Christ Church, Oxford," Chaucer Review 36 (200I): I49-57. On Urry's career see E. I. Carlyle, "Urry, John (I666-I7I5)," rev. A. S. G. Edwards, in ODNB, www.oxforddnb. $\mathrm{com} /$ view/article/2802I.

9 Thomas, "Preface," sigs. ki ${ }^{\mathrm{v}}-\mathrm{k}{ }^{\mathrm{r}}$. See Harris, "An Augustan Episode," 243. 
Io Harris, "An Augustan Episode," 242, citing as well the possibility of a distant relationship between the two men, since Lord Weymouth's second cousin, Mary, married an "Urrey of London."

II On Barnes's edition see Joseph M. Levine, The Battle of the Books: History and Literature in the Augustan Age (Ithaca, N. Y.: Cornell University Press, I99I), I48-57.

I2 $\mathrm{Cr}^{2}$ and $\mathrm{Cr}^{3}$ include the addition of A Prol.90-5, at least one correction from the C tradition, corrections from CUL MS Ll.4.I4 ( $\mathrm{C}^{2}$ of $\left.\mathrm{B}\right)$ or a lost manuscript closely related to it, and readings and apparatus very like C.U.L. MS Gg.4.3I (Hailey, "Robert Crowley and the Editing of Piers Plowman," I55-62).

I3 William L. Alderson and Arnold C. Henderson, Chaucer and Augustan Scholarship (Berkeley: University of California Press, 1970), 98. My thanks to Professor Horobin for informing me of his discovery.

I4 Tyrwhitt, The Canterbury Tales of Chaucer, I:xx. See Alderson and Henderson, Chaucer and Augustan Scholarship, 82 for this and other complaints.

I5 Alderson and Henderson, Chaucer and Augustan Scholarship, 8I, IOI.

I6 Ibid., 82, I45.

I7 $B P, 20$, which is usually omitted from catalogues of the abuses heaped upon Urry's edition.

I8 Bracketed words and lines sometimes occur in The Riverside Chaucer, for instance where Chaucer seem to have cancelled the lines (e.g., Nun's Priest's Tale endlink). But the editors say that they have only "reconsidered with special care" those places where F. N. Robinson "silently restored" grammatical forms such as final $-e$, "and where allowed to stand, notice is taken and the manuscript forms are listed in the Textual Notes": i.e., no brackets (xli-xlii).

I9 Alderson and Henderson, Chaucer and Augustan Scholarship, I02. See also Derek Brewer, "Modernising the Medieval: Eighteenth-Century Translations of Chaucer," in The Middle Ages after the Middle Ages, ed. Marie-Françoise Alamichel and Derek Brewer (Cambridge: D. S. Brewer, 1997), I04, and Joseph A. Dane, Who Is Buried in Chaucer's Tomb? Studies in the Reception of Chaucer's Book (East Lansing: Michigan State University Press, I998), II6-2I.

20 See Alderson and Henderson, Chaucer and Augustan Scholarship, 93, Io6.

2I Ibid., II4, II2.

22 Russell and Nathan, "A Piers Plowman Manuscript in the Huntington Library," I2I.

23 Ibid., I22.

24 Haverford College, Magill Library 96. On Farmer as Librarian, see David McKitterick, Cambridge University Library, a History: The Eighteenth and Nineteenth Centuries (Cambridge: Cambridge University Press, 1986), 29335I; on his book collecting, which centered on early English books, see L. J. Lloyd, "Dr. Richard Farmer, I735-97," Book Collector 26 (I977): 524-36.

25 From Boswell's Life, April 25, I778, as reported in John Nichols, "Dr. John Taylor," in Literary Anecdotes of the Eighteenth Century, Vol. 4 (London, I8I2), 5oon., and McKitterick, Cambridge University Library, I88-9, continuing: "I once dined in company with him; and all he said during the whole time 
was no more than Richard. How a man should say only Richard, it is not easy to imagine. But it was thus: Dr. Douglas was talking of Dr. Zachary Grey, and ascribing to him something that was written by Dr. Richard Grey. So, to correct him, Taylor said (imitating his affected sententious emphasis and nod), Richard!" Nichols's materials on Taylor are quite entertaining; see also McKitterick, I86-95.

26 Nichols, Literary Anecdotes, 493. See McKitterick, Cambridge University Library, 190-5.

27 Nichols, Literary Anecdotes, 5IO.

28 Ibid.

29 Letter to Dr. Ducarel, September I753, advocating Burrell's membership in the Society of Antiquities, printed in Nichols, Literary Anecdotes, 665. On Burrell's career see these items by John H. Farrant: "The Family Circle and Career of William Burrell, Antiquary," Sussex Archaeological Collections 139 (200I): I69-85; Sussex Depicted: Views and Descriptions, I600-I800 (Lewes: Sussex Record Society, 200I); and "Burrell, Sir William, second baronet (I732-I796)," in ODNB: www.oxforddnb.com/view/article/4IO2. R. Carter Hailey describes the copy as "bound in two volumes and interleaved, with text very heavily annotated by Sir William Burrell," but does not mention the Taylor connection, or the nature of the annotations. "Giving Light to the Reader: Robert Crowley's Editions of Piers Plowman (I550)," Ph.D. diss., University of Virginia (200I), 96.

30 For Percy, see Thompson, "Bishop Thomas Percy's Contributions to Langland Scholarship"; for Tyrwhitt, on the basis of his collations of his $\mathrm{Cr}^{\mathrm{I}}$, now B.L. shelfmark C.7I.c.29, against BL MS Cotton Vespasian B XVI, see Hailey, "Robert Crowley and the Editing of Piers Plowman," I45 and n.5.

3I Farrant, "Burrell, Sir William," his $O D N B$ entry.

32 Printed in Nichols, Literary Anecdotes, 520-2. On the history of the Harley library see $A$ Catalogue of the Harleian Collection of Manuscripts . ., 2 vols. (London, I759), I:I-7.

33 Dutschke, Guide, remarks that the price annotations of the Gough and Askew sales by its next owner, Richard Heber (I773-I833), are on the front pastedown and flyleaf.

34 Nichols, Literary Anecdotes, 495-6.

35 "Hearne left all his manuscripts ... to William Bedford, and from Bedford's widow Rawlinson purchased them, probably in 1748 , for $\mathcal{E I O S}_{\mathrm{IO}}$, according to www.bodley.ox.ac.uk/dept/scwmss/wmss/online/I500-I900/rawlinson/rawlinsonCLD.html, under the section of MS K, which includes MS poetry 38 in the list of these items.

36 The copy of Bibliotheca Askeviana manu scripta (London, 1784) that is now BL shelfmark $679 . e .26$ records the names of purchasers.

37 Dutschke, Guide.

38 McKitterick, Cambridge University Library, 328, notes that Gough purchased a Rogers annotated and interleaved by Taylor, but does not attempt to identify it. 
39 William Dunn Macray, Annals of the Bodleian Library, Oxford, A.D. I598-A.D. 1867 (London, 1868), I7I-2. Ian Philip says this is not entirely fair, but the miscataloguing of Rawlinson 272-4 supports the general picture: The Bodleian Library in the Seventeenth and Eighteenth Centuries (Oxford: Clarendon, 1983), 97.

40 See Macray, Annals, 2II-I5.

4I Letter to Sir Thomas Phillipps, April 4, I834, in The Douce Legacy: An Exhibition to Commemorate the Isoth Anniversary of the Bequest of Francis Douce (I757-I834) (Oxford: Bodleian Library, 1984), I7. I correct "suffer" to "suffered" in my transcription.

42 A Catalogue of the Books, relating to British Topography, and Saxon and Northern Literature, Bequeathed to the Bodleian Library, in the Year MDCCXCIX, by Richard Gough, Esq. F.S.A. (Oxford, I8I4). Macray writes that a portion of the Rawlinson MSS were in the same room with the Carte, Dodsworth, Tanner, Willis, and Junius MSS, and that the Gough collection joined them (Annals, 2II).

43 See Strickland Gibson and C. J. Hindle, "Philip Bliss (1787-1857): Editor and Bibliographer," Oxford Bibliographical Society Proceedings and Papers 3 (1933): I79 on his duties of cataloguing the Rawlinson and Gough collections, I87 for the quotation.

44 P. B. [= Philip Bliss], "Pierce Plowman," British Bibliographer I (I810): 443. I thank Dr. Katherine Watson for bringing this item to my attention; it is not in DiMarco, A Reference Guide, and to my knowledge has never been known to Langland scholarship. See Gibson and Hindle, "Philip Bliss," 254 on this item.

45 Bliss, "Pierce Plowman," 444 ("soft" / "set" and MS R's reading, which "differs from any hitherto pointed out"); 447 (Digby I45). See above, Introduction, on Ritson's reference to the two "editions" of Piers Plowman.

46 The Text of the Canterbury Tales, ed. John M. Manly and Edith Rickert, 8 vols. (Chicago: University of Chicago Press, 1940), I:633. The item is A Catalogue of the Libraries of Edward Webbe, Esq; Counsellor at Law, Alexander Davie, Esq; Late of Sidney-College, Cambridge, Francis Carrington, Esq; The Hon. Lady Mary Worsley, and Several Others, With One in Particular, the most considerable of them all, the Name of the Proprietor is not permitted to be published, 2 vols. (London, I751, 1752).

47 Horace Walpole, Memoirs of the Reign of King George III, ed. Derek Jarrett, 4 vols. (New Haven: Yale University Press, 2000), 2:I54-5; see also 3:IIO n.2, 3:I89, and 4:215-17.

48 Where Manly and Rickert in fact encountered this entry (which they represent accurately in its substantives if not accidentals) was London, BL SCS 68, a copy of A Catalogue of the Entire and Valuable Library (with the Exception of the Department of British Topography, Bequeathed to the Bodleian Library) of that Eminent Antiquary, Richard Gough, Esq., Deceased. Which Will be sold by Auction, by Leigh and S. Sotheby, Booksellers, at their House, No. 145, Strand, opposite Catherine Street, on Thursday, April 5, I8Io, and Nineteen following 
Days, (Sundays and Good Friday excepted) at I2 o'Clock (London, I8IO), 204. The sale price they record is what Heber paid for it (see note 33).

49 Manly and Rickert, Text of the Canterbury Tales, I:645.

50 The description available via http://searcharchives.bl.uk (search "Add MS 34360 ") cites the eighteenth-century signature "I. Taylor" on fol. $4^{\mathrm{r}}$ and its later ownership by Askew and Gough. This was one of a number of Stow manuscripts that passed into the hands of William Browne of Tavistock, another of which has Longleat connections (Longleat MS 50, a Polychronicon). See A. S. G. Edwards, "Medieval Manuscripts Owned by William Browne of Tavistock," in Books and Collectors, I200-1650, ed. Colin Tite and James P. Carley (London: British Library, 1996), 44I-9.

5I These are (using modern shelfmarks): Bodleian MSS Laud misc. 58I and 656, Digby I02, I45, and I7I, Bodley 8I4 and 85I, James 2 (excerpts), and Wood donat. 7 (excerpt); CUL MSS Dd.I.I7 and Ll.4.I4; BL Cotton MSS Caligula A XI and Vespasian B XVI; Cambridge, Trinity College MSS B.I5.I7 and R.3.I4; and Cambridge, Corpus Christi College MS 293.

52 A. S. G. Edwards, "The 'Worsley' Manuscript of the Canterbury Tales," The Library 6th ser. 7 (1985): 54-8.

53 A big help for anyone following this up is A. S. G. Edwards, "Two Piers Plowman Manuscripts from Helmingham Hall," Transactions of the Cambridge Bibliographical Society II (I999): 423 n.9, which identifies those manuscripts that were in institutional libraries by the mid-eighteenth century and provides mitigating information about others as well. One minor error is his inclusion of the Douce MSS in that list; they did not arrive at the Bodleian until well into the nineteenth century.

54 Bibliotheca Askeviana manu scripta (London, 1784). This is item SCHOENBERG_97II5 in the Schoenberg Database of Manuscripts, http://dla.library. upenn.edu/dla/schoenberg/index.html.

55 My information on its binding and provenance is from Heinrichs, The Piers Plowman Electronic Archive, Vol. 3, Introduction, I.II, I.I2. There are other problems as well. "Dialogue of Piers Plowman, in English Verse. - The Wards of London, with their Taxes to the I5th - The Privilege of Westminster" is how this item is described in A Catalogue of valuable manuscripts in Greek, Latin, English, French, Italian, and Spanish ... All which were collected at the expence of the late Lord Somers, and since belonged to the Right Hon. Sir Joseph Jekyll Knt. Master of the Rolls (London, I739), 2I, item 669 under the quarto manuscripts. It seems odd that neither Taylor nor the Askew catalogue mentions any of the other items. Oriel 79 belonged to Joseph Ames (I687-I759), and was gifted to Oriel by Francis Page, com-

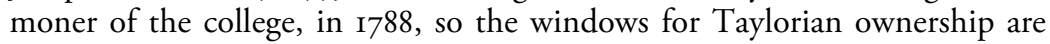
very small in any case. Simon Horobin is tracking the provenance of Oriel 79.

56 See Russell and Kane, The C Version, 7, and Edwards, "Two Piers Plowman Manuscripts," 425. And BL Additional MS 35287 would fit, but it is too big to be described as a quarto. When sold in 1899 , it was described as a folio, 
I2 $\times 8$ inches, bound in crimson morocco. Catalogue of a Portion of the Collection of Manuscripts Known as the "Appendix" Made by the Late Earl of Ashburnham [and sold by H. Yates Thompson], Sotheby's, May I, I899, lot 77, p. 44. For descriptions see Kane and Donaldson, The B Version, II, and Eric Eliason, Thorlac Turville-Petre, and Hoyt N. Duggan, "Introduction," in The Piers Plowman Electronic Archive, Vol. 5: British Library Additional MS $35287(M)$, ed. Eliason, Turville-Petre, and Duggan (Cambridge, Mass.: Boydell and Brewer for the Medieval Academy of America and SEENET, 2005), I.I-9.

57 See Chapter 3. As the Schoenberg database shows, the remainder of Lowes's purchases were Latin and Greek items: Hermogenes, gospels, Homer, patristics, Pliny the Younger, Boethius, Caesar, Cicero, Guido delle Colonne, Justinian, a missal, and Virgil. On Lowes's ownership of Egerton 2864 see Manly and Rickert, Text of the Canterbury Tales, I:I47.

58 Edward Bernard, Catalogi librorum manuscriptorum Angliae et Hiberniae in unum collecti, cum indice alphabetico (Oxford, 1697). This vellum MS is missing eleven leaves, including at the beginning and ending, where Spelman's signature would have been if the losses occurred after he took possession, and which would be most likely to result in a description as imperfect.

59 E. St. John Brooks, "The Piers Plowman Manuscripts in Trinity College, Dublin," The Library 5th ser. 6 (I95I): I53.

60 The Ilchester MS is too small to be described as a folio, and in any case as mentioned above is more likely already to have been in the family than purchased by them at auction. In the Catalogue of the Harleian Collection, Vol. I, Wanley describes MS 875 as a quarto; Rawlinson poet. I37 had a second item at this stage; Rawlinson poet. 38 was probably purchased by Peter Le Neve in East Anglia (The Piers Plowman Electronic Archive, Vol. 7: London, British Library, MS Lansdowne 398, and Oxford, Bodleian MS Rawlinson Poetry 38 (R), ed. Robert Adams [Cambridge, Mass.: Boydell and Brewer for the Medieval Academy of America, 20II], Introduction, I.Io); National Library of Wales $733 \mathrm{~B}$ was almost certainly in private hands in Wales at this point (see Edwards, "Two Piers Plowman Manuscripts," 425, relying on information Dr. Ceridwen Lloyd-Morgan has shared with me as well); and Douce IO4 was owned during Spelman's lifetime by James Ley, first earl of Marlborough (I552-1629). See also note 55 on Oriel 79's status as a quarto and its eighteenth-century provenance.

\section{William Dupré, fabricateur}

I This is from a letter of November I2, I794, to Horace Walpole Bedford, item II4 in The Collected Letters of Robert Southey, ed. Ian Packer and Lynda Pratt, Part One, I79I-I797, available online at www.rc.umd.edu/editions/southey_ letters/Part_One/HTML/letterEEd.26.II4.html. For recent account, see W. A. Speck, Robert Southey: Entire Man of Letters (New Haven: Yale University Press, 2006). 
2 I thank Professor Toshi Takamiya for informing me about this copy. One also wonders whether Southey's attraction to the world of Piers Plowman, and some of his tumult of emotion, is bound up in his composition of the radical play Wat Tyler. On January I2, 1795, he sought out publishers for Wat Tyler, but it did not appear: then, in 1817 , now laureate and a member of the establishment, he saw an advertisement for its forthcoming publication, and he appealed for an injunction against its publication. See Kelly Grovier, "Cause Célèbre," Times Literary Supplement 5742 (April 26, 2013): $3-5$.

3 S. Schoenbaum, "A New Vertue Shakespeare Portrait," Shakespeare Quarterly 28 (1977): 85. On this portrait see Schoenbaum, Shakespeare's Lives, new edn. (Oxford: Clarendon, I99I), 202-6; Margreta de Grazia, Shakespeare Verbatim: The Reproduction of Authenticity and the I79o Apparatus (Oxford: Clarendon, I99I), 79-83; and Tarnya Cooper, ed., Searching for Shakespeare (New Haven: Yale University Press, 2006), esp. 52-75.

4 De Grazia, Shakespeare Verbatim, 8. The best overview of forgery in the eighteenth century is Jack Lynch, Deception and Detection in EighteenthCentury Britain (Aldershot: Ashgate, 2008).

5 James Boaden, An Inquiry into the Authenticity of Various Pictures and Prints, Which, ... Have Been Offered to the Public as Portraits of Shakspeare (London, I824), 39.

6 See ibid., 40-I.

7 William L. Pressly, A Catalogue of Paintings in the Folger Shakespeare Library: "As Imagination Bodies Forth" (New Haven: Yale University Press, 1993), 277, on Folger Shakespeare Library FPsi3. See also Boaden, Inquiry, 8I-II2; Schoenbaum, Shakespeare's Lives, 209-I2.

8 Pressly, Catalogue, 276.

9 The Plays of William Shakespeare, in Fifteen Volumes, ed. Samuel Johnson and George Steevens, 4th edn. (London, I793), r:iv. See Boaden, Inquiry, 44; Schoenbaum, Shakespeare's Lives, 205.

Io Cooper, Searching for Shakespeare, 9. Pressly describes Felton as either "an altered early work or a fake made from whole cloth" (Catalogue, 277); Schoenbaum speculates that perhaps Steevens was behind the ruse (Shakespeare's Lives, 2II-I2). Boaden remarked, "I am assuredly unwilling to believe, that one who took so much interest in the detection of the forged PAPERS of the poet, could at the very time be guilty of counterfeiting his resemblance. But if still such a thing be possible, then I should think the matter capable of some extenuation" and so forth (Inquiry, IO2).

II Boaden, Inquiry, I03-4. See also de Grazia, Shakespeare Verbatim, 85-6, for discussion of the Ireland scandal and the Felton portrait: "William Henry Ireland's fabrication of Elizabethan and Jacobean manuscripts and documents was matched by the appearance of what was, in Malone's eyes at least, a counterfeit portrait of Shakespeare" (85).

I2 See Schoenbaum, Shakespeare's Lives, $135-67$ for full discussion of the forgeries and Malone's role in exposing them. 
I3 George Chalmers, An Apology for the Believers in the Shakspeare-Papers, which were Exhibited in Norfolk-Street (London, I797), 32. Schoenbaum briefly discusses Chalmers: Shakespeare's Lives, 167-8.

I4 Chalmers, Apology, 8; further citations in the text. The last phrase is Steevens's.

I5 The "grappling to his heart" quotation is, of course, from Polonius's advice to Hamlet regarding his friends; "unauthenticated purchase" quotation is Steevens's: "if such a Portrait had existed in Eastcheap during the life of the industrious Vertue, he would most certainly have procured it, instead of having submitted to take his first engraving of our author from a juvenile likeness of James I and his last from Mr. Keck's unauthenticated purchase out of a dressing-room of a modern actress": "Shakspeare," European Magazine 26 (October 1794): 279. See Schoenbaum, Shakespeare's Lives, 583 n. 58 on the attribution to Steevens.

I6 The Monthly Magazine I4 (December I802): 39I. All the letters here cited are now available on GoogleBooks; to find them it is simplest to do a word search of phrases within quotation marks.

I7 Mario Esposito publicized the fraud in "The Letters of Brunetto Latino: A Nineteenth-Century Literary Hoax," Modern Language Review I2 (1917): 59-63, but even so prominent a historian as Ernst Kantorowicz was still misled: Frederick II, II94-I250, trans. E. O. Lorimer (London: Constable, I93I), 354. Others who were ignorant of the correction had already suspected the letters were fake, as Esposito, 6o, points out.

I8 Mario Esposito, "Una falsificazione letteraria del secolo xIx," Archivio storico italiano I3 (I930): IOI-I4.

I9 Claudio Giunta, "Il triste destino di William Dupré, falsario" in Contrafactum: Copia, Imitazione, Falso, ed. Gianfelice Peron and Alvise Andreose (Padua: Esedra, 2008), 267-75; also available as an unpaginated.pdf file linked from www.claudiogiunta.it/2009/03/il-triste-destino-di-william-dupre-falsario. Giunta mentions the Kantorowicz citation (see note 17), at 274.

20 BL Additional MS 46706, fol. $274^{\mathrm{r}-\mathrm{v}}$. Giunta quotes the great majority of these letters as well; I restore original punctuation. I have discovered one other letter in Dupré's hand, but it is in his capacity as secretary to an employer, dated August 2I, I793, and thus reveals little about Dupré other than that he held that position. BL Additional MS 35663, fol. $245^{\mathrm{r}}$.

2I BL Additional MS 22903, fol. 28 $8^{\mathrm{r}-\mathrm{v}}$; Giunta, "Il triste destino," 268-9. Julia Bolton Holloway speculates that MS 319 "came from what may have been Brunetto Latini's own book production center at Arras and that it may even have been written by himself." "Brunetto Latini and England," Manuscripta 3I (1987): I6.

22 Review of Nathaniel William Wraxall, Historical Memoirs of My Own Time (London, I8I5), in The Quarterly Review I3 (I8I5): 205.

23 See W. T. Sherwin, Memoirs of the Life of Thomas Paine (London, I819), iv-v.

24 BL Additional MS 22903, fols. $34^{\mathrm{r}}-35^{\mathrm{r}}$; Giunta, "Il triste destino," 267 , which does not say anything regarding the identity of Chalmers. 
25 The objective of eighteenth-century editors, she points out, "was not the retrieval and preservation of what Shakespeare had put to paper," as it became for Malone and our own era. "The process of establishing and evaluating Shakespeare served the broader cultural ambition of purifying English language, taste, and manners" (Shakespeare Verbatim, 63). So too with the question of history: "The same preoccupation with authenticity characterized Malone's account of Shakespeare's life as it did his treatment of Shakespeare's text; and the same indifference to authenticity typified earlier biographical accounts as it did earlier textual treatments" (7I).

26 See Schoenbaum, Shakespeare's Lives, 66-72, 78 on these three legends.

27 See Alexander Du Toit, "Chalmers, George (bap. I742, d. I825)," in ODNB, www.oxforddnb.com/view/article/5028.

28 The Monthly Magazine I3 (July I802): 553. Holloway claims that the letters were written "in order to encourage the sale of MS Douce 319 to the Bodleian Library" ("Brunetto Latini and England," II), but does not offer any support.

29 The Monthly Magazine I3 (March I802): I29; see Giunta, "Il triste destino," 269. The letter is item 662 of Packer and Pratt, The Collected Letters of Robert Southey, Part Two, I798-I803, www.rc.umd.edu/editions/southey_letters/ Part_Two/HTML/letterEEd.26.662.html.

30 Southey tells the whole sad story in his letter of November 1799 in The Monthly Magazine, accessible in Packer and Pratt, Collected Letters of Robert Southey, Part Two, I798-I803, item 439, www.rc.umd.edu/editions/southey_ letters/Part_Two/HTML/letterEEd.26.439.html. Croft responded in a series of letters, republished as Herbert Croft, Chatterton and Love and Madness: A Letter from Denmark, to Mr. Nichols, Editor of the Gentleman's Magazine, where it appeared in February, March, and April I80o (London, I80o): see Nick Groom, "Love and Madness: Southey Editing Chatterton," in Robert Southey and the Contexts of English Romanticism, ed. Lynda Pratt (Aldershot: Ashgate, 2006), 28, and, on their rivalry, Brian Goldberg, "Romantic Professionalism in I800: Robert Southey, Herbert Croft, and the Letters and Legacy of Thomas Chatterton," ELH 63 (1996): 68I-706.

3I Groom, "Love and Madness," 28.

32 He would recount that in Croft's novel "the fate of Chatterton so strongly interested me, that I used frequently to envy his fate, and desire nothing so ardently as the termination of my existence in a similar cause. Little did I then imagine that the lapse of a few months was to hold me forth to public view as the supposed discoverer of the Shaksperian manuscripts": The Confessions of WilliamHenry Ireland (London, I805), II. See Schoenbaum, Shakespeare's Lives, I36, and Bernard Grebanier, The Great Shakespeare Forgery: A New Look at the Career of William Henry Ireland (London: Heinemann, 1966), 59-69, on which my description of the novel below relies. What Ireland does not mention is that his mother, like the victim of the novel, had been mistress of the earl of Sandwich.

33 Herbert Croft, Love and Madness (London, I780), I38. On the role of forgery in the novel, see Ellen Lévy, "Love and Madness: A Forgery Too True," Plagiary I (2006): 88-99, online at http://hdl.handle.net/2027/spo.524045I.000I.008. 
34 Goldberg, "Romantic Professionalism," 682.

35 The Monthly Magazine I2 (January I802): 525; the remainder appears in I3 (July I802): 549-54.

36 The Monthly Magazine I3 (March I802): I30.

37 See Kelen, "Langland Anthologized," in Langland's Early Modern Identities, 77-IOO.

38 Catalogue of the Printed Books and Manuscripts Bequeathed by Francis Douce, Esq. to the Bodleian Library, part 2, Catalogue of the Manuscripts (Oxford: Oxford University Press, I840), 57; Falconer Madan et al., A Summary Catalogue of Western Manuscripts in the Bodleian Library, 7 vols. (Oxford: Oxford University Press, I895-1953), 4:595. More recently the online Imagining History portal, which describes manuscripts that contain the Brut, quotes Douce's attribution: www.qub.ac.uk/imagining-history/resources/wiki/index.php/ Bodleian_Library,_MS._Douce_323. I have not found it mentioned in any discussion of the manuscripts of Piers Plowman.

39 Wright, Vision, I:xlvi.

40 The great book collector Thomas Corser thought it "worth noticing, that a modern version of the Vision of Pierce Ploughman was attempted some years ago by Mr. Dupré, but it was never printed," citing Madan's description of MS 323. "Mr. Wright also notices an attempt at modernization or translation of this poem, of which he gives a few lines as a specimen, but whether this is the same with that by Mr. Dupre, the editor is unable to say." This is the closest anyone has come to recognizing that the lines Wright prints are those by Dupré in Douce 323. Collectanea Anglo-Poetica, or, a Bibliographical and Descriptive Catalogue of a Portion of a Collection of Early English Poetry, part 9, ed. James Crossley (Manchester: Chetham Society, I879), I55.

4I See Esposito, "Una falsificazione letteraria," I09, on a comment from I863.

42 DiMarco, Reference Guide, vii.

43 Piers Plowman: The Norton Critical Edition, trans. E. Talbot Donaldson, ed. Stephen H. A. Shepherd and Elizabeth Robertson (New York: Norton, 2006); Piers Plowman: A New Translation of the B-Text, trans. A. V. C. Schmidt (Oxford: Oxford University Press, 1992); William Langland's Piers Plowman: The C Version, trans. George Economou (Philadelphia: University of Pennsylvania Press, 1996); Kane, "Poetry and Lexicography."

44 John A. Alford and M. Teresa Tavormina, prefatory note to E. Talbot Donaldson, George Economou, and Richard Barnes, "On Translating Piers Plowman," YLS 3 (1989): I.

45 Ibid.

46 The Vision of Piers, the Plowman: An English Poem of the Fourteenth Century, done into Modern Prose, trans. Kate M. Warren (London, I895). See, e.g., Middleton, "Piers Plowman," 2425.

47 The Critical Review wrote, "we have not the slightest reason to impeach his diligence or his accuracy: on the contrary, we can feely commend both" (35 [I8O2]: I2O); the Union Magazine, "We cannot agree with the author, that his work may be esteemed of little use to those who are intimately acquainted 
with French literature" (2 [I8OI]: 250). A less positive assessment appeared in the Anti-Jacobin Review: "We are rather inclined to think that the author has attempted too much; and that he has united things very much discordant" (9 [I8OI]: 397), but even this concludes by calling it "on the whole, ... an useful publication" (398).

48 Eighteenth-Century Modernizations from The Canterbury Tales, ed. Betsy Bowden (Woodbridge: D. S. Brewer, I99I), x.

49 Ibid., ix.

50 Brewer, "Modernising the Medieval," II3. The introductory note claims that after completing this translation the author, "looking on it as a juvenile Trifle, ... flung it by in a corner of his Study, where it hath lain about thirty Years" (Bowden, Eighteenth-Century Modernizations, 3I-2). Bowden proposes that a search for the author's identity "might begin among other authors published by Jonas Brown, mostly remembered today in footnotes to Pope's Dunciad: Richard Blackmore, Thomas Purney, George Sewell, Lewis Theobold" (3I); Brewer says that in its tone "the rendering has something in common with the writing of Sir John Mennis, the seventeenth-century dirtyminded courtier and rhymester (I59I-I67I) who was Pepys's colleague, who wrote Chaucerian imitations and who, according to Pepys, doted 'mightily' on Chaucer" ("Modernising the Medieval," II3).

5I Brewer, "Modernising the Medieval," II3. All of my quotations from the poem appear on p. 40 of Bowden, Eighteenth-Century Modernizations, and are cited in the text by the line numbers she supplies. I emend "of" to "or" in quoting line 856 .

52 This is the only confession printed by Warton; Ritson prints the whole passus (see Kelen, Langland's Early Modern Identities, 93, 95).

53 See Introduction, note 47.

54 Esposito, "Una falsificazione letteraria," Iо3 n.3; Giunta, "Il triste destino," 267, 269.

55 R. D. Sheldon, "Page, Frederick (1769-1834)," in ODNB, www.oxforddnb. $\mathrm{com} /$ view/article/21093.

56 "I conceive these 3 leaves to be part of a transcript from one of the MSS of P. Plowman's Visions in the Harl. Collection \& made by a Mr. Page who about twelve years since frequented the reading room for that purpose. F. D. I809" (fol. 29 $9^{r}$ ), Douce writes in the margin, but the source is clearly the Cotton Vespasian MS. I discovered it by looking under "In a somer seson" in the first-line index in the British Library manuscripts reading room; I have never seen any other mention of it.

57 The Monthly Magazine I6 (January I804): 564.

58 Giunta, "Il triste destino," 274 n.9, saying he could find no trace in either the British Library or the Biblioteca Nazionale di Parigi.

59 Memoirs of Margaret de Valois, Queen of Navarre; the First Wife of Henry the Fourth of France, commonly called The Great: Containing, the Secret History of the Court of France, for Seventeen Years, viz. from I565 to I582, during the Reigns of Charles IX. and Henry III. Including a Full Account of the Massacre of the 
Protestants, on St. Bartholomew's Day, Written by Herself, in a Series of Letters, 2 vols. (London, I813). Worldcat.org lists three copies, one of which, now in the University of Wisconsin Library, is available as part of the Hathi Trust Digital Library: http://catalog.hathitrust.org/Record/005973550. In I895 and ? I900 the edition would be reprinted as part of the "Court Memoir series," with a somewhat shorter title and still as anonymous as ever. Memoirs of Margaret de Valois, Queen of Navarre Containing the Secret History of the Court of France for Seventeen Years, viz., from 1565 to 1582, during the Reigns of Charles IX. and Henry III. Written by Herself, in a Series of Letters (London, I895; Philadelphia, n.d. [?1900]).

6o The Monthly Review 72 (December I813): 437.

6I Duprés translation is included in the bibliography of A Celebration of Women Writers: Writers Living between ISOI and I60o, http://digital.library.upenn.edu/ women/_generate/I50I-I60o.html.

62 The Douce Legacy, I46.

63 E.g., on the covers of The Vision of Piers Plowman: A Critical Edition of the $B$-Text, rev. edn., ed. A. V. C. Schmidt (London: Dent, 1995), and Anna Baldwin, A Guidebook to Piers Plowman (New York: Palgrave Macmillan, 2007).

\section{Conclusion}

I Simpson, Reform and Cultural Revolution, chapter I, "The Melancholy of John Leland and the Beginnings of English Literary History" (7-33).

2 Anthony A. Wood, "John Leland," in Athene Oxonienses: An Exact History of all the Writers and Bishops Who Have Had Their Education in the University of Oxford, ed. Philip Bliss, 3 vols. (London, I813), r:col. 198.

3 Simpson, Reform and Cultural Revolution, II.

4 Ibid., I7.

5 George Kane, "Langland and Chaucer: An Obligatory Conjunction" (198I), in Kane, Chaucer and Langland, 123-33. See Bowers, Chaucer and Langland for the most extensive of the many recent studies of this conjunction.

6 Henry Bradley, review of Skeat's parallel-text edition, as cited in DiMarco, Reference Guide, item I887.3.

7 Robert Aris Willmott, Lives of the English Sacred Poets, 2nd edn., Vol. I (London, I839), 6.

8 Kathleen Forni, The Chaucerian Apocrypha: A Counterfeit Canon (Gainesville: University of Florida Press, 200I), IO.

9 The classic treatment of Chaucer reception is Caroline Spurgeon, Five Hundred Years of Chaucer Criticism and Allusion (I357-1900), 5 parts in 3 vols. (1908-17; rpt. Cambridge: Cambridge University Press, 1925); quotations are by part. For Langland, the equivalent to Spurgeon is DiMarco, Reference Guide; see also especially Hudson, "Epilogue," 25I-66, and Kelen, Langland's Early Modern Identities.

Io John Leland, De Uiris Illustribus: On Famous Men, ed. and trans. James P. Carley (Toronto: Pontifical Institute of Mediaeval Studies, 2010), 708-9. 
II Alexandra Gillespie, Print Culture and the Medieval Author: Chaucer, Lydgate, and Their Books, I473-I557 (Oxford: Oxford University Press, 2006), I99.

I2 Leland, De Uiris Illustribus, Appendix 4, p. 844. Carley somewhat confusingly says that the paper stock on which the Chaucer chapter is written, Briquet II383, "was not used for entries in Stage I, but it appeared soon afterwards. A number of entries in a characteristic hand, not quite identical to Stage I (cc. I80, 218, 246 etc.), are written on this paper" (cxxxii). Carley seems simply to mean that these are the products of the final stages of Stage I, as it were. He assigns the Chaucer chapter to Stage I on the basis of handwriting, placenames, and personal names.

I3 Francis Thynne, Animaduersions vppon the Annotaciones and Corrections of some imperfections of impressiones of Chaucers workes (sett downe before tyme, and nowe) reprinted in the yere of oure lorde 1598 , ed. F. J. Furnivall, Chaucer Society. 2nd ser., I3 (London, I876), 7.

I4 Gillespie, Print Culture, 199.

I5 This copy, now Huntington Library 88317, is dated c.1533: see The Plowman's Tale: The c.1532 and 1606 Editions of a Spurious Canterbury Tale, ed. Mary Rhinelander McCarl (New York: Garland, I977), ı6, 45. There is also a MS of the tale added to an I832 Thynne, now University of Texas, Q PR I850 I532. Annie S. Irvine argues that it represents an independent textual tradition: "A Manuscript Copy of The Plowman's Tale," University of Texas Studies in English I2 (1932): 27-56. But Joseph A. Dane asserts instead the likelihood that it is simply a copy of the 1542 edition: "Bibliographical History versus Bibliographical Evidence: The Plowman's Tale and Early Chaucer Editions," Bulletin of the John Rylands University Library of Manchester 78 (1996): 60-I n.30. Gillespie puts forth some textual evidence for the idea that "The Plowman's Tale had an independent life in some lost edition or one or more manuscripts," which in her view strengthens the idea that it might have attracted Leland's attention (Print Culture, 200), but she does not address Dane's demurral. In any case by that logic Piers Plowman itself is still a more probable candidate.

I6 Bodleian MS Digby I45 (c.I53I-2); C.U.L. MS Gg.4.3I (s. xvi ${ }^{\mathrm{I}}$ ); and B.L. MS Royal I8 B XviI (s. xvi ${ }^{\mathrm{I}}$ ). The excerpt in the Winchester Anthology, too, is from around this time (Chapter 4 ).

I7 John Dryden, "Preface" to Fables Ancient and Modern (London, I70o), sig. B.ii ${ }^{\mathrm{v}}$.

I8 Carley writes: "Although the De uiris illustribus was less widely copied than Leland's other prose remains, in part because Bale's bibliographical efforts appeared to replace it in the eyes of many individuals, antiquaries did continue to consult it" (Leland, De Uiris Illustribus, cxlix). Dryden certainly seems to have known it.

I9 Horobin, "Stephan Batman." Batman owned Bodleian MS Digby I7I, on whose title page he offered a summary of the poem's virtues and a drawing of a ploughman, and, as Horobin now argues, Cambridge, Trinity College MS R.3.I4. 
20 This text was first published in an item called "The Vision of Pierce Plowman" by one "Silverstone" in N\&Q 2nd ser. 6, I42 (I858): 229-30; see DiMarco, Reference Guide, item I577.I; Spurgeon, Five Hundred Years, 4:4I (Appendix A). I have silently corrected some obvious errors in Silverstone's transcription. This copy was sold by Sotheby's as lot I6 on May 25, I972, and for $\$ 19,975$ by Christie's sale 9878, lot 77, October 8-9, 200I. It had been owned by Daniel Wray (I7OI-83); its current whereabouts are unknown. The Bale material is from his Catalogus of 1557-9; for discussion see Kelen, Langland's Early Modern Identities, 22-7. For the Bale material, see Chapter 4 at note 52.

2I The Plowman's Tale, I533, lines I065-6, in McCarl's edition.

22 See DiMarco, Reference Guide, items Post I546.I (Bale's ascription), I580.I (Stow, with full discussion of the history of the ascription and of its possible referents), and discussion by, among others, Benson, Public Piers Plowman, 4-5; Edwards, "Piers Plowman in the Seventeenth Century."

23 See, e.g., the inscription after the explicit in Liverpool University Library MS F.4.8, p. 202, image at http://www.liv.ac.uk/library/sca/colldescs/medrenmss/ images/LUL_MS_F_4_8_2IO.jpg, mentioning both candidates. Often an owner will endorse one candidate, and a later owner will counter with the other, as in the final page and first end flyleaf of the $\mathrm{Cr}^{\mathrm{I}}$ in the Folger Shakespeare Library, shelfmark STC I9906, at http://luna.folger.edu/luna/ servlet/s/I062dp, or University of Michigan, shelfmark PR20IO.C95 I550, a $\mathrm{Cr}^{3}$ in which three hands debate the matter.

24 The Romaunt of the Rose, lines 216I-2.

25 Seth Lerer, "Latin Annotations in a Copy of Stowe's Chaucer and the Seventeenth-Century Reception of Troilus and Criseyde," RES n.s. 53 (2002): 5-6. Lerer observes that "Pieces of Chaucer's poem [i.e., Troilus] were often excised, copied out, and rearranged into independent lyrics, centos of memorable lines, or verse epistolary exchanges" (6); I do not know of any equivalent tradition regarding the Romaunt.

26 A Catalogue of the Harleian Collection of Manuscripts ... , Vol. I (London, I759), entry for MS 875 .

27 A Catalogue of the Harleian Collection of Manuscripts ..., Vol. 2, entry for MS 2376.

28 Wanley's final entry was for MS 2407: see A Preface and Index to the Harleian Collection of Manuscripts (London, I763), 27.

29 Spurgeon, Five Hundred Years, 2:4I-2. The only other notice of the attribution I have encountered occurs in the opening sentence of Pamela Gradon, "Langland and the Ideology of Dissent," Proceedings of the British Academy 66 (I980): I79, which must rely on Spurgeon.

30 www.bl.uk/catalogues/illuminatedmanuscripts/ > “2376."

3I Tyrwhitt, Canterbury Tales of Chaucer, 4:74 n. 57.

32 On the eighteenth-century tendency toward plagiarism among scholars of Piers Plowman, see Vincent DiMarco, "Godwin on Langland," YLS 6 (I992): I25.

33 Ritson, $B P, 27$. 
34 Lehigh University Library 82I.I L265p I550, Frontmatter [5].

35 Ritson, Ancient Songs, From the Time of King Henry III, to the Revolution (London, I790), xxxii n. Much of Ancient Songs had been printed by 1786 or I787, and its title page bears the date I790, but it did not appear until summer I792; see Bronson, Joseph Ritson, I76. See also DiMarco, Reference Guide, item I782.I; cf. Kelen, Langland's Early Modern Identities, 4I-2.

36 Farmer cites it in the flyleaves of his Rogers, Haverford, Magill 96, adding ruefully that his friend "does not mention" that reason. Soon after they first met Ritson called Farmer "a most sensible, liberal, benevolent and worthy man," and the two scholars' cordiality, observes Bronson, "seems not to have been broken off, in spite of the bolts which Ritson continued to discharge at the heads of Farmer's friends" (Joseph Ritson, 393). Farmer either did not ask his friend for his reasons, or did not record the answer here. So does Mitford, in the verso of the first flyleaf of his copy, where it is in bolder and more prominent script than are any of his numerous other references to contemporary scholarship, and in his review of Wright, The Vision and creed of Piers Ploughman, The Gentleman's Magazine n.s. I9 (April I843): 340 n.

37 Ritson, BP, 29-3I.

38 Ibid., I9-20 n., citing Thomas Chatterton, Miscellanies in Prose and Verse (London, 1778), 137, which enables the provision of a missing quotation mark in Ritson's text, provided here.

39 Quoted in Haslewood, Some Account, 3I-2 n, and Bronson, Joseph Ritson, 380, whose text I follow.

40 Kelen, Langland's Early Modern Identities, I32.

4I Douce's comment about the dagger collection is in a letter of November 5, I823, to his friend and biographer Haslewood, in endpapers of BL G.I3I23. See Bronson, Joseph Ritson, 54 n.8.

42 Bowers, Chaucer and Langland.

43 William H. Sherman, Used Books: Marking Readers in Renaissance England (Philadelphia: University of Pennsylvania Press, 2008), xii-xiii.

44 Simpson, Reform and Cultural Revolution, 32. See also Ralph Hanna, review of Brewer, Editing Piers Plowman, Speculum 73 (1998): 477-8, citing comments by A. S. G. Edwards. 


\section{Bibliography}

This bibliography is divided into five sections: (I) books and essays published $c .1550-1843$; (2) primary sources: editions and translations, c.I867-20I2; (3) reference materials (i.e., catalogues, bibliographies, indexes, histories of libraries); (4) biographical works; and (5) literary, bibliographical, historical, and cultural criticism published from $c .1858$ to 2013. There are some fine distinctions, especially in the treatment of editions of Langland, but they are not difficult to navigate. Manuscripts and individual books appear in a separate list in the Index of manuscripts, early printed books, annotated books, and portraits.

\section{BOOKS AND ESSAYS PUBLISHED $c .1550-1843$ (EXCEPT CATALOGUES, ETC.)}

Anonymous. Items in The Monthly Magazine. Retraction of William Duprés "Brunetto" letters, I4 (I802): 39I. Announcement of publication of Dupré's Memoirs of Margaret de Valois, 16 (I804): 564.

Reviews of Dupré, Lexicographia-Neologica Gallica. Anti-Jacobin Review 9 (I8OI): 397-8; The Critical Review 35 (I802): I20; Union Magazine 2 (I8OI): 249-52.

Review of Dupré, Memoirs of Margaret de Valois. The Monthly Review 72 (December I813): 436-7.

Review of Nathaniel William Wraxall, Historical Memoirs of My Own Time (London, I815). The Quarterly Review I3 (1815): 193-215.

Bale, John. Scriptorum illustrium maioris brytannie ... Basle, I559.

B[liss], P[hilip]. "Pierce Plowman." British Bibliographer I (1810): 443-8.

Boaden, James. An Inquiry into the Authenticity of Various Pictures and Prints, Which, from the decease of the Poet to Our Own Times, Have Been Offered to the Public as Portraits of Shakspeare. London, I824.

Chalmers, George. An Apology for the Believers in the Shakspeare-Papers, which were Exhibited in Norfolk-Street. 1797.

Chatterton, Thomas. Miscellanies in Prose and Verse. London, 1778. 
Churchyard, Thomas. Davy Dycars Dreame. London, ?1547. Transcription at http:// quod.lib.umich.edu/e/eebo/Aı8727.000I.00I/1:I?rgn=divi;view=fulltext.

Croft, Herbert. Chatterton and Love and Madness: A Letter from Denmark, to Mr. Nichols, Editor of the Gentleman's Magazine, where it appeared in February, March, and April I80o. London, I800.

Love and Madness. London, 1780.

Crowley, Robert, ed. The Vision of Pierce Plowman, now fyrste imprinted by Roberte Crowley, dwellyng in Ely rentes in Holborn. Anno Domini, I505. London, I550. $\left[=\mathrm{Cr}^{\mathrm{I}}\right]$

ed. The Vision of Pierce Plowman, now the seconde time imprinted by Roberte Crowley dwellynge in Elye rentes in Holborn. Whereunto are added certayne notes and cotations in the mergyne, geuynge light to the Reader. London, $1550 .\left[=\mathrm{Cr}^{2}\right]$

ed. The Vision of Pierce Plowman, nowe the seconde tyme imprinted by Roberte Crowlye dwellynge in Elye rentes in Holborne. Whereunto are added certayne notes and cotations in the mergyne, geuyng light to the Reader. London, $1550 .\left[=\mathrm{Cr}^{3}\right]$

Dryden, John. Fables Ancient and Modern. London, I70o.

Dupré, William. Letters supposedly from Brunetto Latini and other items. The Monthly Magazine I2 (I8O2): 524-5; I3 (I8O2): I3O-I, 237-40, 355-9, 447-50, 549-54.

Lexicographia-Neologica Gallica: The neological French dictionary; containing words of new creation,... The Whole forming a Remembrancer of the French Revolution. London, I8oI.

[ed. and trans.] Memoirs of Margaret de Valois, Queen of Navarre; the First Wife of Henry the Fourth of France, commonly called The Great: Containing, the Secret History of the Court of France, for Seventeen Years, viz. from I565 to I582, during the Reigns of Charles IX. and Henry III. Including a Full Account of the Massacre of the Protestants, on St. Bartholomew's Day, Written by Herself, in a Series of Letters, 2 vols. London, I8I3; 2nd edn. London, I895; Philadelphia, n.d. (?1900).

Haslewood, Joseph. Some Account of the Life and Publications of the Late Joseph Ritson, Esq. London, I824.

Ireland, William-Henry. The Confessions of William-Henry Ireland. London, I805.

Johnson, Samuel, and George Steevens, eds. The Plays of William Shakespeare, in Fifteen Volumes. 4th edn. Vol. I. London, I793.

Malone, Edmond. Inquiry into the Authenticity of Certain Miscellaneous Papers... Attributed to Shakespeare. London, 1796.

[Mitford, John.] Review of Wright, The Vision and Creed of Piers Ploughman. The Gentleman's Magazine n.s. I9 (I843): 339-58.

Nichols, John. "Dr. John Taylor." Literary Anecdotes of the Eighteenth Century. Vol. 4. London, I812. 490-535, 662-6.

Ritson, Joseph. Ancient Songs, From the Time of King Henry III, to the Revolution. London, I790.

Bibliographia Poetica. London, I802.

Rogers, Owen, ed. The Vision of Pierce Plowman, newlye imprynted after the authours olde copy. London, I56I. 
Sherwin, W. T. Memoirs of the Life of Thomas Paine. London, I8I9.

[Steevens, George.] "Shakspeare." European Magazine 26 (October 1794): 277-8I.

Tanner, Thomas. Bibliotheca Britannico-Hibernica. London, 1748.

Tyrwhitt, Thomas, ed. The Canterbury Tales of Chaucer. 5 vols. London, 1775-8. Urry, John, ed., with a Preface by Timothy Thomas. The Works of Geoffrey Chaucer. London, I72I.

Warton, Thomas. The History of English Poetry ... : A New Edition Carefully Revised [by Richard Price]. 4 vols. London, I824. Observations on the Faerie Queene of Spenser. London, 1754.

Whitaker, Thomas D., ed. Visio Willi de Petro Plouhman. London, i8rz.

Willmott, Robert Aris. Lives of the English Sacred Poets. 2nd edn. Vol. I. London, I839.

Wright, Thomas, ed. The Vision and Creed of Piers Ploughman. 2 vols. London, I842. "The Visions of Piers Plowman." The Gentleman's Magazine n.s. I (I834): $385-91$.

\section{PRIMARY SOURCES: EDITIONS AND TRANSLATIONS,} c.I $867-2012$

Ancrene Wisse, Parts Six and Seven. Ed. Geoffrey Shepherd. Manchester: Manchester University Press, 1972.

Augustine. Augustine: Sermons on the Liturgical Seasons. Trans. Mary Sarah Muldowney. New York: Fathers of the Church, 1959.

Calendar of Letter-Books ... of the City of London: Letter-Book H, ca. A.D. 13751399. Ed. Reginald R. Sharpe. London: John Edward Francis, 1907.

Cassian, John. The Twelve Books of John Cassian on the Institutes of the Coenobia. A Select Library of Nicene and Post-Nicene Fathers of the Christian Church, Second Series. Vol. II. Trans. Edgar C. S. Gibson. New York: Rivingtons, I894.

Chaucer, Geoffrey. The Book of Troilus and Criseyde. Ed. R. K. Root. Princeton: Princeton University Press, 1926.

The Legend of Good Women. Ed. A. S. G. Edwards and M. C. E. Shaner. In Benson, The Riverside Chaucer. 588-630.

The Riverside Chaucer. 3rd edn. Gen. ed. Larry D. Benson. Boston: Houghton Mifflin, 1987.

The Romaunt of the Rose. Ed. Alfred David. In Benson, The Riverside Chaucer. 686-767.

The Text of the Canterbury Tales. Ed. John M. Manly and Edith Rickert. 8 vols. Chicago: University of Chicago Press, 1940.

Chronica Monasterii S. Albani: Registra Quorundam Abbatum Monasterii S. Albani, Vol. 2: Registra Johannis Whethamstede, Willelmi Albon, et Willelmi Walingforde. Ed. Henry Thomas Riley. London, I873.

Constantine of Pisa. Constantine of Pisa, The Book of the Secrets of Alchemy: Introduction, Critical Edition, Translation and Commentary. Ed. Barbara Obrist Leiden. New York: Brill, I990. 
Dante Alighieri. Dante Alighieri: De Situ et Forma Aque et Terre. Ed. Giorgio Padoan. Florence: Le Monnier, 1968.

Guillaume de Palerne-poet. Guillaume de Palerne: An English Translation of the I2th Century French Verse Romance. Ed. and trans. Leslie A. Sconduto. Jefferson, N.C.: McFarland, 2004.

Guillaume de Palerne: Roman du XIIIe Siècle. Ed. Alexandre Micha. Geneva: Droz, I990.

The Holy Bible. Douay Rheims Version. Rev. Richard Challoner. I899. Baltimore: Tan Books, I989.

Langland, William. [See also William of Palerne-poet.]

\section{(a) Modern critical editions}

Piers Plowman: The A Version. Rev. edn. Ed. George Kane. London: Athlone Press, I988.

Piers Plowman: The B Version. Rev. edn. Ed. George Kane and E. Talbot Donaldson. London: Athlone Press, 1988.

Piers Plowman: The C Version. Ed. George Russell and George Kane. London: Athlone Press, 1997.

Piers Plowman: A New Annotated Edition of the C-Text. Ed. Derek Pearsall. Exeter: University of Exeter Press, 2008.

Piers Plowman: A Parallel-Text Edition of the A, B, C and $Z$ Versions. Vol. I, Text; Vol. 2, Introduction, Textual Notes, Commentary, Bibliography and Indexical Glossary. Ed. A. V. C. Schmidt. Kalamazoo, Mich.: Medieval Institute Publications, 20II.

Piers Plowman: The Prologue and Passus I-VII of the B text as Found in Bodleian MS. Laud 58r. Ed. J. A. W. Bennett. Oxford: Clarendon, 1972.

Piers Plowman by William Langland: An Edition of the C-Text. Ed. Derek Pearsall. York: York Medieval Press, 1978.

Piers Plowman: The $Z$ Version. Ed. A. G. Rigg and Charlotte Brewer. Toronto: Pontifical Institute of Mediaeval Studies, 1983.

The Vision of Piers Plowman: A Critical Edition of the B-Text. Rev. edn. Ed. A. V. C. Schmidt. London: Dent, 1995.

The Vision of William, Concerning Piers Plowman: The "Vernon" Text; or Text A.

Ed. Walter W. Skeat. EETS o.s. 28. London: Trübner, I867.

The Vision of William Concerning Piers the Plowman: The "Whitaker" Text; or Text C. Ed. Walter W. Skeat. EETS o.s. 54. London: Trübner, I873.

The Vision of William Concerning Piers the Plowman in Three Parallel Texts. 2 vols. Ed. Walter W. Skeat. London: Oxford University Press, I886.

(b) Facsimile editions of individual MSS

A Facsimile Edition of the Vernon Manuscript: Oxford, MS. Eng. poet. a.I. Bodleian Digital Texts. Ed. Wendy Scase. Oxford: Bodleian, 2012.

The Piers Plowman Electronic Archive, Vol. 2: Cambridge, Trinity College, MS B.I5.I7 (W). Ed. Thorlac Turville-Petre and Hoyt N. Duggan. Ann Arbor: SEENET and University of Michigan Press, 2000. 
The Piers Plowman Electronic Archive, Vol. 3: Oxford, Oriel College MS 79 (O). Ed. Katherine Heinrichs. Woodbridge: Boydell and Brewer for the Medieval Academy of America and SEENET, 2004.

The Piers Plowman Electronic Archive, Vol. 5: London, British Library Additional MS 35287 (M). Ed. Eric Eliason, Thorlac Turville-Petre, and Hoyt N. Duggan. Cambridge, Mass.: Boydell and Brewer for the Medieval Academy of America and SEENET, 2005.

The Piers Plowman Electronic Archive, Vol. 7: London, British Library, MS Lansdowne 398, and Oxford, Bodleian MS Rawlinson Poetry 38 (R). Ed. Robert Adams. Cambridge, Mass.: Boydell and Brewer for the Medieval Academy of America, 20II.

Piers Plowman: A Facsimile of the Z-Text in Bodleian Library, Oxford, MS Bodley 85I. Intro. Charlotte Brewer and A. G. Rigg. Cambridge: D. S. Brewer, 1994 .

William Langland's The Vision of Piers Plowman: The A-Text: A Facsimile of Trinity College, Cambridge MS R.3.I4. Ed. Tomonori Matsushita. Tokyo: Senshu University Press, 2010.

William Langland's The Vision of Piers Plowman: The C-Text: A Facsimile of Huntington Library, San Marino, MS Hm I43. Ed. Tomonori Matsushita. Tokyo: Senshu University Press, 2010.

\section{(c) Translations}

Piers Plowman: A New Translation of the B-Text. Trans. A. V. C. Schmidt. Oxford: Oxford University Press, 1992.

Piers Plowman: The Norton Critical Edition. Trans. E. Talbot Donaldson. Ed. Stephen H. A. Shepherd and Elizabeth Robertson. New York: Norton, 2006.

The Vision of Piers, the Plowman: An English poem of the Fourteenth Century, done into Modern Prose. Trans. Kate M. Warren. London, I895.

William Langland's Piers Plowman: The C Version. Trans. George Economou Philadelphia: University of Pennsylvania Press, 1996.

Leland, John. De Uiris Illustribus: On Famous Men. Ed. and trans. James P. Carley. Toronto: Pontifical Institute of Mediaeval Studies, 2010.

Letters and Papers, Foreign and Domestic, of the Reign of Henry VIII. Vols. Io and I2. Ed. James Gairdner. London: HM Stationery Office, I887, I89o.

"The Miller of Trompington: Being an Exercise upon Chaucer's Reeve's Tale." I7I5. In Bowden, Eighteenth-Century Modernizations (section 5). 3I-54.

Mum and the Sothsegger. In The Piers Plowman Tradition, ed. Helen Barr. London: J. M. Dent, 1993. 135-202.

Peter of Auvergne. Peter of Auvergne: Questions on Aristotle's De Caelo: A Critical Edition with an Interpretative Essay. Ed. Griet Galle. Leuven: Leuven University Press, 2003.

The Plowman's Tale: The c.I532 and I606 Editions of a Spurious Canterbury Tale. Ed. Mary Rhinelander McCarl. New York: Garland, 1977.

Southey, Robert. The Collected Letters of Robert Southey. Ed. Ian Packer and Lynda Pratt. www.rc.umd.edu/editions/southey_letters/letterEEd.26.about.html. 
Thynne, Francis. Animaduersions vppon the Annotaciones and Corrections of some imperfections of impressiones of Chaucers workes (sett downe before tyme, and nowe) reprinted in the yere of oure lorde I598. Ed. F. J. Furnivall. Chaucer Society, 2nd ser., I3. London, I876.

Walpole, Horace. Memoirs of the Reign of King George III. Ed. Derek Jarrett. 4 vols. New Haven: Yale University Press, 2000.

The Westminster Chronicle, I38I-1394. Ed. and trans. L. C. Hector and Barbara F. Harvey. Oxford: Clarendon, I982.

William of Palerne-poet. [See also Langland, William.]

The Romance of William of Palerne, or, William and the Werwolf: Together with a Fragment of the Alliterative Romance of Alisaunder. Ed. Walter W. Skeat. EETS e.s. I. London: Oxford University Press, I867.

William of Palerne, an Alliterative Romance. Ed. G. H. V. Bunt. Groningen: Bouma's Boekhuis, 1985 .

William of Palerne: An Electronic Edition. Ed. G. H. V. Bunt. Ann Arbor: University of Michigan Press, 2002.

The Winchester Anthology: A Facsimile of British Library Additional Manuscript 60577 with an Introduction and List of Contents by Edward Wilson and an Account of the Music by Iain Fenlon. Cambridge: D. S. Brewer, I98I.

\section{CATALOGUES, BIBLIOGRAPHIES, INDEXES, HISTORIES} OF LIBRARIES

\section{(a) Auction catalogues}

Alexander Pope (I688-I744): Occasional List No. IIo, Ximines Rare Books. Kempsford, $c .2012$.

Bibliotheca Askeviana manu scripta. London, 1784 .

A Catalogue of the Entire and Valuable Library (with the Exception of the Department of British Topography, Bequeathed to the Bodleian Library) of that Eminent Antiquary, Richard Gough, Esq., Deceased. Which Will be sold by Auction, by Leigh and S. Sotheby, Booksellers, at their House, No. I45, Strand, opposite Catherine Street, on Thursday, April 5, I8Io, and Nineteen following Days, (Sundays and Good Friday excepted) at I2 O'Clock. London, I8Io.

A Catalogue of the Libraries of Edward Webbe, Esq; Counsellor at Law, . . and Several Others, With One in Particular, the most considerable of them all, the Name of the Proprietor is not permitted to be published. 2 vols. London, I75I, I752.

Catalogue of a Portion of the Collection of Manuscripts Known as the "Appendix" Made by the Late Earl of Ashburnham [and sold by H. Yates Thompson]. Sotheby's. May I, I899.

A Catalogue of valuable manuscripts in Greek, Latin, English, French, Italian, and Spanish ... All which were collected at the expence of the late Lord Somers, and since belonged to the Right Hon. Sir Joseph Jekyll Knt. Master of the Rolls. London, I739. 
Catalogue of the Very Select and Valuable Library of William Roscoe Esq. London, I8I6.

The Trivulzio Collection. Part the Second. Catalogue of sale, 6-II February, I888.

\section{(b) Library and exhibition catalogues}

Bernard, Edward. Catalogi librorum manuscriptorum Angliae et Hiberniae in unum collecti, cum indice alphabetico. Oxford, I697.

Black, W. H. A Descriptive, Analytical and Critical Catalogue of the Manuscripts Bequeathed unto the University of Oxford by Elias Ashmole Esq. Oxford, I845.

Bodleian Library. A Catalogue of the Books, relating to British Topography, and Saxon and Northern Literature, Bequeathed to the Bodleian Library, in the Year MDCCXCIX, by Richard Gough, Esq. F.S.A. Oxford, I8I4.

Catalogue of the Printed Books and Manuscripts Bequeathed by Francis Douce, Esq. to the Bodleian Library. Part 2, Catalogue of the Manuscripts. Oxford: Oxford University Press, I840.

Description of Rawlinson MSS. www.bodley.ox.ac.uk/dept/scwmss/wmss/ online/I500-I900/rawlinson/rawlinsonCLD.html.

The Douce Legacy: An Exhibition to Commemorate the Isoth Anniversary of the Bequest of Francis Douce (I757-I834). Oxford: Bodleian Library, I984.

British Museum/British Library. Manuscript Catalogue. Incorporated into http:// searcharchives.bl.uk.

A Catalogue of the Harleian Collection of Manuscripts . . . 2 vols. London, 1759. Illuminated Manuscript Catalogue. www.bl.uk/catalogues/illuminated manuscripts/welcome.htm/.

A Preface and Index to the Harleian Collection of Manuscripts. London, 1763.

Cooper, Tarnya, ed. Searching for Shakespeare. New Haven: Yale University Press, 2006.

Corser, Thomas. Collectanea Anglo-Poetica, or, a Bibliographical and Descriptive Catalogue of a Portion of a Collection of Early English Poetry. Part 9. Ed. James Crossley. Manchester: Chetham Society, I879.

Dutschke, C. W., with the assistance of R. H. Rouse et al. Guide to Medieval and Renaissance Manuscripts in the Huntington Library. San Marino: Huntington Library, 1989. http://sunsite.berkeley.edu/hehweb/toc.html.

Hanna, Ralph, and Thorlac Turville-Petre, eds. The Wollaton Medieval Manuscripts: Texts, Owners and Readers. York: York Medieval Press, 2010.

James, M. R. The Western Manuscripts in the Library of Trinity College, Cambridge: A Descriptive Catalogue. 4 vols. Cambridge: Cambridge University Press, I900-4.

Madan, Falconer, et al. A Summary Catalogue of Western Manuscripts in the Bodleian Library. 7 vols. Oxford: Oxford University Press, I895-1953.

Nasmith, James. Catalogus Librorum Manuscriptorum quos Collegio Corporis Christi ... Cambridge, 1777.

Pressly, William L. A Catalogue of Paintings in the Folger Shakespeare Library: "As Imagination Bodies Forth." New Haven: Yale University Press, 1993. 


\section{(c) Bibliographies, author catalogues, atlases, and databases}

Benson, C. David, and Lynne Blanchfield. The Manuscripts of Piers Plowman: The B Version. Cambridge: D. S. Brewer, 1997.

A Celebration of Women Writers: Writers Living between I50I and I60o. http:// digital.library.upenn.edu/women/_generate/I50I-I600.html.

DiMarco, Vincent. Piers Plowman: A Reference Guide. Boston: G. K. Hall, 1982. Geographies of Orthodoxy: Mapping English Pseudo-Bonaventuran Lives of Christ, I350-I550. www.qub.ac.uk/geographies-of-orthodoxy/.

Hanna, Ralph. The English Manuscripts of Richard Rolle: A Descriptive Catalogue. Exeter: University of Exeter Press, 2010.

Imagining History: Perspectives on Late Medieval Vernacular Historiography. www. qub.ac.uk/imagining-history/resources/wiki/index.php/Main_Page.

Late Medieval English Scribes. Ed. Linne R. Mooney, Simon Horobin, and Estelle Stubbs. www.medievalscribes.com.

McIntosh, Angus, M. L. Samuels, and Michael Benskin, eds. A Linguistic Atlas of Late Mediaeval English. 4 vols. Aberdeen: Aberdeen University Press, I986.

Marginalia of Piers Plowman. Ed. Christine Schott. www.rarebookschool.org/ fellowships/rbs-uva/plowman6.html.

Schoenberg Database of Manuscripts. http://dla.library.upenn.edu/dla/ schoenberg/index.html.

Spurgeon, Caroline. Five Hundred Years of Chaucer Criticism and Allusion (I3571900). 5 parts in 3 vols. I908-17; rpt. Cambridge: Cambridge University Press, I925.

\section{(d) Dictionaries, indexes, and concordances}

Alford, John A. Piers Plowman: A Guide to the Quotations. Binghamton, N.Y.: Medieval and Renaissance Texts and Studies, 1992.

Crum, Margaret, ed. First-Line Index of English Poetry I500-I80o in Manuscripts of the Bodleian Library Oxford. Vol. 2. Oxford: Clarendon, 1969.

Kuist, James M. The Nichols File of The Gentleman's Magazine: Attributions of Authorship and Other Documentation in Editorial Papers at the Folger Library. Madison: University of Wisconsin Press, 1982.

Middle English Dictionary. Ed. Hans Kurath et al. Ann Arbor: University of Michigan Press, I952-200I. http://quod.lib.umich.edu/m/med.

Oxford English Dictionary. OED Online. http://oed.com.

Ringler, William A., Jr. Bibliography and Index of English Verse in Manuscript I5OII558. Prepared and completed by Michael Rudick and Susan J. Ringler. London: Mansell, 1992.

Walther, Hans. Initia carminum ac versum Medii Aevui posterioris Latinorum. Göttingen: Vandenhoeck und Ruprecht, 1969.

Proverbia Sententiaeque Latinitatis Medii Aevi. 5 vols. Göttingen: Vandenhoeck und Ruprecht, 1963-7. 
Whiting, Bartlett Jere, with the collaboration of Helen Wescott Whiting. Proverbs, Sentences, and Proverbial Phrases from English Writings Mainly before 1500. Cambridge, Mass.: Harvard University Press, 1969.

Wittig, Joseph S. Piers Plowman: Concordance. London: Continuum, $200 \mathrm{I}$.

\section{(e) Histories of libraries}

The Friars' Libraries. Ed. K. W. Humphreys. London: British Library, I990.

McKitterick, David. Cambridge University Library, a History: The Eighteenth and Nineteenth Centuries. Cambridge: Cambridge University Press, I986.

Macray, William Dunn. Annals of the Bodleian Library, Oxford, A.D. I598-A.D. I867. London, I868.

Philip, Ian. The Bodleian Library in the Seventeenth and Eighteenth Centuries. Oxford: Clarendon, 1983.

\section{BIOGRAPHICAL WORKS (BY SUBJECT)}

Audelay, John. Michael J. Bennett, "John Audley: Some New Evidence on His Life and Work." Chaucer Review I6 (I982): 344-55.

"Beauchamp, Thomas, Eleventh Earl of Warwick (1313/I4-1369)." Anthony Tuck, $O D N B$, www.oxforddnb.com/view/article/53085.

Bliss, Philip. Strickland Gibson and C. J. Hindle, "Philip Bliss (I787-I857): Editor and Bibliographer." Oxford Bibliographical Society Proceedings and Papers 3 (I933): I74-260.

Bohun family: Alice, Humphrey. The Complete Peerage of England, Scotland, Ireland, Great Britain and the United Kingdom ... , ed. G. E. Cokayne; new edn., rev. Vicary Gibbs, Geoffrey H. White, et al., I3 vols. in I4. London: St. Catherine, I910-59. 6:459-62; I2.I:77I-2.

Emma Mason, Beauchamp Cartulary Charters, II00-I268. London: Pipe Roll Society, I980. 2I4-I6.

"Brynstan, John." Joan Greatrex, Biographical Register of the English Cathedral Priories of the Province of Canterbury, c.1066-1540. Oxford: Clarendon, I997. 678.

"Buriton, John.” Greatrex, Biographical Register (previous entry). 678-9.

"Burrell, Sir William, second baronet (I732-I796)." John H. Farrant, ODNB, www.oxforddnb.com/view/article/4IO2.

John H. Farrant, "The Family Circle and Career of William Burrell, Antiquary." Sussex Archaeological Collections 139 (2001): 169-85.

John H. Farrant, Sussex Depicted: Views and Descriptions, I600-I800. Lewes: Sussex Record Society, $200 I$.

"Chalmers, George (bap. I742, d. I825)." Alexander Du Toit, ODNB, www. oxforddnb.com/view/article/5028.

Chaucer, Geoffrey. Chaucer Life-Records. Ed. Martin M. Crow and Clair C. Olson from materials compiled by John M. Manly and Edith Rickert, with the assistance of Lilian J. Redstone and others. Oxford: Clarendon, 1966. 
Dackomb, Thomas. Andrew G. Watson, "A Sixteenth-Century Collector: Thomas Dackomb, I496-c.I572." The Library 5th ser. I8 (I963): 204-I7.

Dupré, William. Claudio Giunta, "Il triste destino di William Dupré, falsario." In

Contrafactum: Copia, Imitazione, Falso, ed. Gianfelice Peron and Alvise Andreose. Padua: Esedra, 2008. 267-75.

Farmer, Richard. (See also section 3e, McKitterick, 293-35I.)

L. J. Lloyd, “Dr. Richard Farmer, I735-97.” Book Collector 26 (I977): 524-36.

Fortescue, Adrian. Richard Rex, "Blessed Adrian Fortescue: A Martyr without a Cause?" Analecta Bollandiana II5 (1997): 307-53.

Ireland, William-Henry. (See also section I, s.v. "Ireland, William-Henry.")

Bernard Grebanier, The Great Shakespeare Forgery: A New Look at the Career of William Henry Ireland. London: Heinemann, 1966.

Langland, William. Robert Adams, Langland and the Rokele Family: The Gentry Background to Piers Plowman. Dublin: Four Courts Press, 2013.

Michael J. Bennett, "William Called Long Will.” YLS 26 (20I2): I-25.

Ralph Hanna, William Langland. Aldershot: Variorum, 1993.

Leland, John. Anthony A. Wood, "John Leland." In Athene Oxonienses: An Exact History of all the Writers and Bishops Who Have Had Their Education in the University of Oxford. Ed. Philip Bliss. 3 vols. London, I8I3. I: cols. 197-204. Marsh, George Perkins. David Lowenthal, George Perkins Marsh: Versatile Vermonter. New York: Columbia University Press, 1958.

"Mitford, John (I78I-I859)." W. P. Courtney, rev. James Edgar Barcus, Jr., $O D N B$, www.oxforddnb.com/view/article/I8856.

"Page, Frederick (I769-I834)." R. D. Sheldon, ODNB, www.oxforddnb.com/ view/article/21093.

Ritson, Joseph. (See also section I, "Haslewood, Joseph.")

Bertrand H. Bronson, Joseph Ritson, Scholar at Arms. Berkeley: University of California Press, 1938.

Henry Alfred Burd, Joseph Ritson, A Critical Biography. Urbana: University of Illinois Press, I916.

David Matthews, The Making of Middle English, I765-I9I0. Minneapolis: University of Minnesota Press, 1999. 25-53.

James M. Osborn, "Joseph Ritson, Scholar at Odds." MP 37 (I940): 419-29.

Southey, Robert. Kelly Grovier, "Cause Célèbre." Times Literary Supplement 5742 (April 26, 2013): 3-5.

W. A. Speck, Robert Southey: Entire Man of Letters. New Haven: Yale University Press, 2006.

"Stafford, Hugh, Second Earl of Stafford (c.1342-I386)." Carole Rawcliffe, $O D N B$, www.oxforddnb.com/view/article/26206.

Taylor, John. (See section I, "Nichols, John"; and section 3e, McKitterick, I86-95.)

Toeni family: Ralph and daughter Alice. The Complete Peerage ... (see s.v. "Bohun"). I2.I:774; I2.2:37I-2.

"Urry, John (I666-I715)." E. I. Carlyle, rev. A. S. G. Edwards, ODNB, www. oxforddnb.com/view/article/2802I. 
Waldegrave, Richard. J. S. Roskell, "Sir Richard de Waldegrave of Bures St. Mary, Speaker in the Parliament of 138I-2." Suffolk Institute of Archaeology 27.3 (1957): 154-75.

\section{LITERARY, BIBLIOGRAPHICAL, HISTORICAL, AND CULTURAL WORKS, $c .1858-2013$}

Adams, Robert. "The Kane-Donaldson Edition of Piers Plowman: Eclecticism's Ultima Thule." Text I6 (2006): I3I-4I.

"The Reliability of the Rubrics in the B-Text of Piers Plowman." ME 54 (1985): 208-3I.

Ahlström, G. W. "Oral and Written Transmission: Some Considerations." Harvard Theological Review 59 (1966): 69-8I.

Alderson, William L., and Arnold C. Henderson. Chaucer and Augustan Scholarship. Berkeley: University of California Press, 1970.

Alford, John A., ed. A Companion to Piers Plowman. Berkeley: University of California Press, 1988.

"More Unidentified Quotations in Piers Plowman." MP 8I (1984): 278-85.

"The Role of the Quotations in Piers Plowman." Speculum 52 (1977): 80-99.

Alford, John A., and M. Teresa Tavormina. Prefatory note to E. Talbot Donaldson, George Economou, and Richard Barnes, "On Translating Piers Plowman." YLS 3 (1989): I-29.

Allen, Bessie F. "The Genealogy of the C Text Manuscripts of Piers Plowman." MA thesis, University of London, 1923.

Baldwin, Anna P. A Guidebook to Piers Plowman. New York: Palgrave Macmillan, 2007.

"The Triumph of Patience in Julian of Norwich and Langland." In Langland, the Mystics and the Medieval English Religious Tradition: Essays in Honour of S. S. Hussey, ed. Helen Phillips. Cambridge: D. S. Brewer, 1990. 7I-83.

Barney, Stephen A. The Penn Commentary on Piers Plowman, Vol. 5: C Passus 20-22; B Passus I8-20. Philadelphia: University of Pennsylvania Press, 2006.

Barr, Helen. "The Relationship of Richard the Redeless and Mum and the Sothsegger: Some New Evidence." YLS 4 (1990): IO5-33.

Signes and Sothe: Language in the Piers Plowman Tradition. Cambridge: D. S. Brewer, 1994.

"The Use of Latin Quotations in Piers Plowman with Special Reference to Passus xviII of the 'B' Text." NerQ n.s. 33 (1986): 440-8.

Barron, Caroline. "William Langland: A London Poet." In Chaucer's England: Literature in Historical Context, ed. Barbara Hanawalt. Minneapolis: University of Minnesota Press, 1992. 9I-I09.

Barron, W. R. J. "Alliterative Romance and the French Tradition." In Lawton, Middle English Alliterative Poetry and Its Literary Background. 70-87.

Bart, Patricia R. "Intellect, Influence, and Evidence: The Elusive Allure of the $\mathrm{Ht}$ Scribe." In Yee? Baw for Bokes: Essays on Medieval Manuscripts and Poetics in 
Honor of Hoyt N. Duggan, ed. Michael Calabrese and Stephen H. A. Shepherd. Los Angeles: Marymount Institute Press, 2013. 219-43.

Bennett, Michael J. "Mandeville's Travels and the Anglo-French Moment." MEE 75 (2006): 273-92.

Benson, C. David. Public Piers Plowman: Modern Scholarship and Late Medieval English Culture. University Park: Pennsylvania State University Press, 2004. Bird, Ruth. The Turbulent London of Richard II. London: Longmans, Green, I949. Black, Merja. “A Scribal Translation of Piers Plowman." MAE 67 (I998): 257-90. Bloomfield, Morton W. "Present State of Piers Plowman Studies." Speculum I4 (1939): 215-32.

Bowden, Betsy, ed. Eighteenth-Century Modernizations from The Canterbury Tales. Woodbridge: D. S. Brewer, I99I.

Bowers, John M. Chaucer and Langland: The Antagonistic Tradition. Notre Dame, Ind.: University of Notre Dame Press, 2007.

The Crisis of Will in Piers Plowman. Washington, D.C.: Catholic University of America Press, 1986.

"Dating Piers Plowman: Testing the Testimony of Usk's Testament." YLS I3 (I999): 65-IOO.

Brewer, Charlotte. Editing Piers Plowman: The Evolution of the Text. Cambridge: Cambridge University Press, 1996.

Brewer, Derek. "Modernising the Medieval: Eighteenth-Century Translations of Chaucer." In The Middle Ages after the Middle Ages, ed. Marie-Françoise Alamichel and Derek Brewer. Cambridge: D. S. Brewer, 1997. I03-20.

Brooks, E. St. John. "The Piers Plowman Manuscripts in Trinity College, Dublin." The Library 5th ser. 6 (I95I): I4I-53.

Bunt, Gerrit H. V. "Localizing William of Palerne." In Historical Linguistics and Philology, ed. Jacek Fisiak. Berlin and New York: Mouton, 1990. 73-86.

Burrow, John A. "God and the Fullness of Time in Piers Plowman." MAE 79 (20I0): 300-5.

"The Structure of Piers Plowman B xv-xx: Evidence from the Rubrics." $M A$ 77 (2008): 306-I2.

Burrow, John A., and Hoyt N. Duggan, eds. Medieval Alliterative Poetry: Essays in Honour of Thorlac Turville-Petre. Dublin: Four Courts Press, 2010.

Butterfield, Ardis. The Familiar Enemy: Chaucer, Language, and Nation in the Hundred Years War. Oxford: Oxford University Press, 2009.

Caie, Graham D. "The Significance of the Early Chaucer Manuscript Glosses (with Special Reference to the Wife of Bath's Prologue)." Chaucer Review Io (1976): 350-60.

Calabrese, Michael. "Prostitutes in the C-Text of Piers Plowman." JEGP ios (2006): 275-3II.

Cannon, Christopher. "Langland's Ars Grammatica." YLS 22 (2008): I-25.

Carnegy, F. A. R. An Attempt to Approach the C-Text of Piers the Plowman. London: University of London Press, 1934.

Cassidy-Welch, Megan. Imprisonment in the Medieval Religious Imagination, c.II50-I400. New York: Palgrave Macmillan, 201 . 
Chism, Christine. Alliterative Revivals. Philadelphia: University of Pennsylvania Press, 2002.

Clay, Mary Rotha. The Hermits and Anchorites of England. London: Methuen, I9I4.

Clifton, Nicole. "The Romance Convention of the Disguised Duel and the Climax of Piers Plowman." YLS 7 (1993): 123-8.

Clopper, Lawrence M. "Langland's Markings for the Structure of Piers Plowman." MP 85 (1988): 245-55.

Cooper, Helen. Review of The Winchester Anthology. RES n.s. 35 (1984): 354-5.

Cooper, R. A., and Derek A. Pearsall. "The Gawain Poems: A Statistical Approach to the Question of Common Authorship.” RES n.s. 39 (I988): $365-85$.

Dahl, Eric. "Diuerse Copies Haue it Diuerselye: An Unorthodox Survey of Piers Plowman Textual Scholarship from Crowley to Skeat." In Suche Werkis to Werche: Essays on Piers Plowman in Honor of David C. Fowler, ed. Míceál F. Vaughan. East Lansing, Mich.: Colleagues Press, 1993. 53-80.

Dalrymple, Roger. Language and Piety in Middle English Romance. Cambridge: D.S. Brewer, 2000.

Dane, Joseph A. "Bibliographical History versus Bibliographical Evidence: The Plowman's Tale and Early Chaucer Editions." Bulletin of the John Rylands University Library of Manchester 78 (I996): 47-6I.

Who Is Buried in Chaucer's Tomb? Studies in the Reception of Chaucer's Book. East Lansing: Michigan State University Press, 1998.

Davis, Bryan P. "The Prophecies of Piers Plowman in Cambridge University Library MS Gg.4.3I." Journal of the Early Book Society 5 (2002): 20-4I.

De Grazia, Margreta. Shakespeare Verbatim: The Reproduction of Authenticity and the I790 Apparatus. Oxford: Clarendon, I99I.

Derrida, Jacques. Archive Fever: A Freudian Impression. Trans. Eric Prenowitz. Chicago: University of Chicago Press, 1996.

Diamond, Arlyn. "Loving Beasts: The Romance of William of Palerne." In The Spirit of Medieval English Popular Romance, ed. Ad Putter and Jane Gilbert. London: Pearson, 2000. I42-56.

DiMarco, Vincent. "Eighteenth-Century Suspicions Regarding the Authorship of Piers Plowman." Anglia Ioo (1982): I24-9.

"Godwin on Langland." YLS 6 (1992): 123-35.

Dodds, Madeleine Hope. "Political Prophecies in the Reign of Henry VIII." Modern Language Review II (1916): 276-84.

Donaldson, E. Talbot. Piers Plowman: The C-Text and Its Poet. New Haven: Yale University Press, 1949. Rpt. New York: Frank Cass, 1966.

Doyle, A. I. "Remarks on Surviving Manuscripts of Piers Plowman." In Medieval English Religious and Ethical Literature: Essays in Honour of G. H. Russell, ed. Gregory Kratzmann and James Simpson. Cambridge: D. S. Brewer, I986. 35-48.

Duggan, Hoyt N. "I994 Prospectus: Creating an Electronic Archive of Piers Plowman." www3.iath.virginia.edu/seenet/piers/archivegoalsi994body.html. 
"Notes on the Metre of Piers Plowman: Twenty Years On." In Approaches to the Metres of Alliterative Verse, ed. Judith Jefferson and Ad Putter. Leeds: Leeds Studies in English, 2009. I59-86.

"Notes Toward a Theory of Langland's Meter." YLS I (I987): 4I-70.

Duggan, Hoyt N., with Eugene Lyman. "A Progress Report on The Piers Plowman Electronic Archive." The Digital Medievalist I (2004). www. digitalmedievalist.org/journal/I.I/duggan/\#d33284e755.

Dyas, Dee. "A Pilgrim in Sheep's Clothing? The Nature of Wandering in Piers Plowman." English Language Notes 39.4 (2002): I-I2.

Echard, Siân. "With Carmen's Help: Latin Authorities in the Confessio Amantis." Studies in Philology 95 (1998): I-40.

Edwards, A. S. G. "The Blage Manuscript and Alliterative Verse in the Sixteenth Century." In Burrow and Duggan, Medieval Alliterative Poetry. 80-4.

"Medieval Manuscripts Owned by William Browne of Tavistock." In Books and Collectors, I200-I650, ed. Colin Tite and James P. Carley. London: British Library, 1996. 44I-9.

"Piers Plowman in the Seventeenth Century: Gerard Langbaine's Notes." YLS 6 (I992): I4I-4.

"Shapes Arbitrarily Determined." Times Literary Supplement 5662 (October 7, 20II): 27.

"Two Piers Plowman Manuscripts from Helmingham Hall." Transactions of the Cambridge Bibliographical Society II (I999): 42I-6.

"The 'Worsley' Manuscript of the Canterbury Tales." The Library 6th ser. 7 (1985): 54-8.

Emmerson, Richard K. “'Yernen to rede redels?' Piers Plowman and Prophecy." YLS 7 (1993): 27-76.

Esposito, Mario. "The Letters of Brunetto Latino: A Nineteenth-Century Literary Hoax." Modern Language Review I2 (1917): 59-63.

"Una falsificazione letteraria del secolo XIX." Archivio storico italiano I3 (I930): IOI-I4.

Fein, Susanna, ed. My Wyl and My Wrytyng: Essays on John the Blind Audelay. Kalamazoo: Medieval Institute, 2009.

Forni, Kathleen. The Chaucerian Apocrypha: A Counterfeit Canon. Gainesville: University of Florida Press, 200 I.

Foucault, Michel. The Archaeology of Knowledge and The Discourse on Language. Trans. A. M. Sheridan Smith. New York: Tavistock, I972.

"What Is an Author?" In Language, Counter-Memory, Practice: Selected Essays and Interviews by Michel Foucault, ed. Donald F. Bouchard, trans. Donald F. Bouchard and Sherry Simon. Ithaca, N.Y.: Cornell University Press, 1977. II3-38.

Fowler, Elizabeth. "Civil Death and the Maiden: Agency and the Conditions of Contract in Piers Plowman." Speculum 70 (1995): 760-92.

Gaffney, Wilber. "The Allegory of the Christ-Knight in Piers Plowman." PMLA 46 (I93I): 155-68.

Galloway, Andrew. "The Account Book and the Treasure: Gilbert Maghfeld's Textual Economy and the Poetics of Mercantile Accounting in Ricardian Literature." Studies in the Age of Chaucer 33 (2OII): 65-I24. 
"Latin England." In Imagining a Medieval English Nation, ed. Kathy Lavezzo. Minneapolis: University of Minneapolis Press, 2004. 4I-95.

The Penn Commentary on Piers Plowman, Vol. I: C Prologue-Passus 4; B Prologue-Passus 4; A Prologue-Passus 4. Philadelphia: University of Pennsylvania Press, 2006.

"The Rhetoric of Riddling in Late-Medieval England: The 'Oxford' Riddles, the Secretum Philosophorum, and the Riddles in Piers Plowman." Speculum 70 (1995): 68-I05.

Gasquet, Francis Aidan. The Last Abbot of Glastonbury and His Companions: An Historical Sketch. London: S. Marshall, Hamilton, Kent, I895.

Gillespie, Alexandra. Print Culture and the Medieval Author: Chaucer, Lydgate, and Their Books, I473-I557. Oxford: Oxford University Press, 2006.

Gillespie, Alexandra, and Daniel Wakelin, eds. The Production of Books in England I350-I500. Cambridge: Cambridge University Press, 20II.

Given-Wilson, Chris. The English Nobility in the Late Middle Ages. 1987; New York: Routledge, 1996.

Goldberg, Brian. "Romantic Professionalism in I80o: Robert Southey, Herbert Croft, and the Letters and Legacy of Thomas Chatterton." ELH 63 (1996): 68I-706.

Gradon, Pamela. "Langland and the Ideology of Dissent." Proceedings of the British Academy 66 (1980): 179-205.

Green, Richard Firth. "Humphrey and the Werewolf." In Burrow and Duggan, Medieval Alliterative Poetry. I07-24.

"Langland and Audelay." In Fein, My Wyl and My Wrytyng. I53-69.

Greetham, David. "Who's In, Who's Out': The Cultural Poetics of Archival Exclusion." Studies in the Literary Imagination 32 (1999): I-28.

Grindley, Carl. "A New Fragment of the Piers Plowman C Text?" YLS II (I997): I35-40.

Groom, Nick. "Love and Madness: Southey Editing Chatterton." In Robert Southey and the Contexts of English Romanticism, ed. Lynda Pratt. Aldershot: Ashgate, 2006. 19-36.

Gwynn, Aubrey. The English Austin Friars in the Time of Wyclif. London: Oxford University Press, 1940.

Hailey, R. Carter. "Giving Light to the Reader: Robert Crowley's Editions of Piers Plowman (I550)." Ph.D. diss., University of Virginia, 200I.

"Robert Crowley and the Editing of Piers Plowman (I550)." YLS 2I (2007): I43-70.

Hanna, Ralph. "Alliterative Poetry." In The Cambridge History of Medieval English Literature, ed. David Wallace. Cambridge: Cambridge University Press, 1999. 488-5I2.

London Literature, I300-I380. Cambridge: Cambridge University Press, 2005.

Pursuing History: Middle English Manuscripts and Their Texts. Stanford: Stanford University Press, 1996.

Review of Brewer, Editing Piers Plowman. Speculum 73 (1998): 477-80.

Harris, Kate. "An Augustan Episode in the History of the Collection of Medieval Manuscripts at Longleat House." In The English Medieval Book: Studies in 
Memory of Jeremy Griffiths, ed. A. S. G. Edwards, Vincent Gillespie, and Ralph Hanna. London: British Library, 2000. 233-47.

Holloway, Julia Bolton. "Brunetto Latini and England." Manuscripta 3I (I987): II-2I.

Horobin, Simon. "'In London and Opelond': The Dialect and Circulation of the C Version of Piers Plowman." ME 74 (2005): 248-69.

"John Cok and his Copy of Piers Plowman." YLS 27 (2013): forthcoming.

"A Manuscript Found in the Library of Abbotsford House and the Lost Legendary of Osbern Bokenham." English Manuscript Studies II00-I700 I4 (2007): 132-64.

"Mapping the Words." In Gillespie and Wakelin, Production of Books. 59-78.

"Politics, Patronage, and Piety in the Work of Osbern Bokenham." Speculum 82 (2007): 932-49.

"Richard James and the Seventeenth-Century Provenance of British Library MS Cotton Caligula A.XI." Journal of the Early Book Society I3 (20IO): 249-54.

"The Scribe of Bodleian Library, MS Digby IO2 and the Circulation of the C Text of Piers Plowman." YLS 24 (20I0): 89-II2.

"Stephan Batman and His Manuscripts of Piers Plowman." RES n.s. 62 (2011): $358-72$.

Hudson, Anne. "Epilogue: The Legacy of Piers Plowman." In Alford, A Companion to Piers Plowman. 25I-66.

Hussey, S. S. "Langland's Reading of Alliterative Poetry." Modern Language Review 6o (1965): 163-70.

Irvine, Annie S. "A Manuscript Copy of The Plowman's Tale." University of Texas Studies in English I2 (1932): 27-56.

Jansen [Jaech], Sharon L. "British Library MS Sloane 2578 and Popular Unrest in England, I554-I556." Manuscripta 29 (1985): 30-4I.

Political Protest and Prophecy under Henry VIII. Woodbridge: Boydell, I99I.

"Politics, Protest, and a New Piers Plowman Fragment: The Voice of the Past in Tudor England.” RES n.s. 40 (1989): 93-9.

Jefferson, Judith A. "Divisions, Collaboration and Other Topics: The Table of Contents in Cambridge, University Library, MS Gg.4.3I." In Burrow and Duggan, Medieval Alliterative Poetry. I40-52.

Jeffrey, David Lyle. "Wolves in Sheep's Clothing." In A Dictionary of Biblical Tradition in English Literature, ed. David Lyle Jeffrey. Grand Rapids, Mich.: Eerdmans, I992. 844 .

Johnston, Michael. "From Edward III to Edward VI: The Vision of Piers Plowman and Early Modern England." Reformation II (2006): 47-78.

Jones, Mike Rodman. “'This is no prophecy': Robert Crowley, Piers Plowman, and Kett's Rebellion." Sixteenth Century Journal 42 (201I): 37-55.

Jusserand, J. J. "Piers Plowman: The Work of One or of Five." MP 6 (1909): 27I-329.

Justice, Steven. Writing and Rebellion: England in I38I. Berkeley: University of California Press, I994.

Justice, Steven, and Kathryn Kerby-Fulton, eds. Written Work: Langland, Labor, and Authorship. Philadelphia: University of Pennsylvania Press, 1997. 
Kane, George. Chaucer and Langland: Historical and Textual Approaches. London: Athlone Press, I989.

"Langland and Chaucer: An Obligatory Conjunction." In Kane, Chaucer and Langland. I23-33.

"Langland and Chaucer ir." In Kane, Chaucer and Langland. 134-49.

Middle English Literature: A Critical Study of the Romances, the Religious Lyrics,

Piers Plowman. New York: Barnes and Noble, 195I.

"Outstanding Problems of Middle English Scholarship." In Kane, Chaucer and Langland. 228-4I.

Piers Plowman: The Evidence for Authorship. London: Athlone Press, 1965.

"Poetry and Lexicography in the Translation of Piers Plowman." In Kane, Chaucer and Langland. 90-106.

"The Text." In Alford, A Companion to Piers Plowman. 175-200.

Kantorowicz, Ernst. Frederick II, II94-I250. Trans. E. O. Lorimer. London: Constable, I93I.

Kelen, Sarah A. "Cultural Capital: Selling Chaucer's Works, Building Christ Church, Oxford." Chancer Review 36 (200I): I49-57.

Langland's Early Modern Identities. New York: Palgrave Macmillan, 2007.

Kerby-Fulton, Kathryn. "Langland and the Bibliographic Ego." In Justice and Kerby-Fulton, Written Work. 67-I43.

Reformist Apocalypticism and Piers Plowman. Cambridge: Cambridge University Press, 1990.

Kerby-Fulton, Kathryn, and Steven Justice. "Scribe D and the Marketing of Ricardian Literature." In The Medieval Professional Reader at Work: Evidence from Manuscripts of Chaucer, Langland, Kempe, and Gower, ed. Kathryn Kerby-Fulton and Maidie Hilmo. Victoria, B.C.: University of Victoria, 200I. 217-38.

King, John N. English Reformation Literature: The Tudor Origins of the Protestant Tradition. Princeton: Princeton University Press, 1982.

Kirk, Elizabeth D. The Dream Thought of Piers Plowman. New Haven: Yale University Press, 1972.

Lawler, Traugott. "Langland Translating." In Answerable Style: The Idea of the Literary in Medieval England, ed. Andrew Galloway and Frank Grady. Columbus: Ohio State University Press, 2013. 54-74.

"Langland Versificator." YLS 25 (20II): 37-76.

"William Langland." In The Oxford History of Literary Translation in English, Vol. I: To I550, ed. Roger Ellis. Oxford: Oxford University Press, 2008. I49-59.

Lawton, David A. "Alliterative Style." In Alford, A Companion to Piers Plowman. 233-49.

ed. Middle English Alliterative Poetry and Its Literary Background: Seven Essays. Cambridge: D. S. Brewer, 1982.

"The Unity of Middle English Alliterative Poetry." Speculum 58 (1983): 72-94. 
Lerer, Seth. "Latin Annotations in a Copy of Stowe's Chaucer and the Seventeenth-Century Reception of Troilus and Criseyde." RES n.s. 53 (2002): I-7.

Levine, Joseph M. The Battle of the Books: History and Literature in the Augustan Age. Ithaca, N.Y.: Cornell University Press, I99I.

Lévy, Ellen. "Love and Madness: A Forgery Too True." Plagiary I (2006): 88-99. http://hdl.handle.net/2027/spo.5240451.0001.008.

Lewis, C. S. The Allegory of Love: A Study in Medieval Tradition. Oxford: Oxford University Press, 1936.

Lynch, Jack. Deception and Detection in Eighteenth-Century Britain. Aldershot: Ashgate, 2008.

Machan, Tim William. "Language Contact in Piers Plowman." Speculum 69 (1994): 359-85.

McIntosh, Angus. "Early Middle English Alliterative Verse." In Lawton, Middle English Alliterative Poetry and Its Literary Background. 20-33.

Manly, John M. "The Authorship of Piers the Plowman." MP I4 (1916): 315-16.

Mann, Jill. "The Power of the Alphabet: A Reassessment of the Relation between the A and the B Versions of Piers Plowman." YLS 8 (I994): 2I-50.

Marsh, George P. The Origin and History of the English Language, and of the Early Literature It Embodies. London, I862.

Marx, C. W. The Devil's Rights and the Redemption in the Literature of Medieval England. Cambridge: D. S. Brewer, 1995.

Meech, Sanford B. "A Collection of Proverbs in Rawlinson MS D 328." MP 38 (I940): II3-32.

Meecham-Jones, Simon. "For Mr. Ritson's Collection: George Ellis, Joseph Ritson and National Library of Wales MSS 5599, 5600c." English Studies 82 (200I): I27-45.

Middleton, Anne. "Acts of Vagrancy: The C Version 'Autobiography' and the Statute of I388." In Justice and Kerby-Fulton, Written Work. 208-317.

"Piers Plowman." In A Manual of the Writings in Middle English, I050-I50o, ed. Albert E. Hartung. New Haven: Connecticut Academy of Arts and Sciences, I986. 22II-34.

"William Langland's 'Kynde Name': Authorial Signature and Social Identity in Late Fourteenth-Century England." In Patterson, Literary Practice and Social Change in Britain. 15-82.

Mills, David. "The Rôle of the Dreamer in Piers Plowman." In Piers Plowman: Critical Approaches, ed. S. S. Hussey. London: Methuen, 1969. I8O-2I2.

Mitchell, A. G. "Notes on the C-Text of Piers Plowman." London Mediaval Studies I (I948 for I939): 483-92.

Modern Language Association. "Prize for a Bibliography, Archive, or Digital Project." www.mla.org/resources/awards/awards_submissions/awards_competitions/ prizes_biennial20I4/prizeinfo_bib. 
Mooney, Linne R., and Estelle Stubbs. Scribes and the City: London Guildhall Clerks and the Dissemination of Middle English Literature, I375-I425. York: York Medieval Press, 20I3.

Mulder-Bakker, Anneke B. Lives of the Anchoresses: The Rise of the Urban Recluse in Medieval Europe. Trans. Myra Heerspink Scholz. Philadelphia: University of Pennsylvania Press, 2005 .

Nightingale, Pamela. A Medieval Mercantile Community: The Grocers' Company and the Politics and Trade of London I000-I485. New Haven: Yale University Press, 1995.

Oakden, J. P. Alliterative Poetry in Middle English: The Dialectal and Metrical Survey. Manchester: Manchester University Press, 1930.

Partridge, Stephen. "Designing the Page." In Gillespie and Wakelin, Production of Books, 79-103.

Pates, Stella. "A New Discovery: Piers Plowman and Manuscript Bodley 463." www.piersplowman.com/piersplowman_discovery.htm.

Patterson, Lee, ed. Literary Practice and Social Change in Britain, I380-I530. Berkeley: University of California Press, 1988.

Paul, John E. "Hampshire Recusants in the Time of Elizabeth I, with Special Reference to Winchester." Proceedings of the Hampshire Field Club 2I (1959): 6I-8I.

Pearsall, Derek. "Audelay's Marcolf and Solomon and the Langlandian Tradition." In Fein, My Wyl and My Wrytyng. 138-52.

"Langland's London." In Justice and Kerby-Fulton, Written Work. 185-207.

Review of The Winchester Anthology. N\&Q n.s. 30 (1983): I6I-5.

Prendergast, Thomas A. "The Work of Robert Langland." In Renaissance Retrospections: Tudor Views of the Middle Ages, ed. Sarah A. Kelen. Kalamazoo, Mich.: Medieval Institute, 2013. 70-92.

Pugh, Ralph. Imprisonment in Medieval England. Cambridge: Cambridge University Press, 1968.

Rice, Joanne. "Explanatory Notes to the Franklin's Prologue and Tale." In Benson, The Riverside Chaucer (section II, s.v. "Chaucer"). 895-90I.

Rigg, A. G. "John of Bridlington's Prophecy: A New Look." Speculum 63 (1988): 596-613.

Roberts, Jane. Guide to Scripts Used in English Writings up to I50o. London: British Library, 2005.

Russell, George H. "“As they read it': Some Notes on Early Responses to the CVersion of Piers Plowman." Leeds Studies in English n.s. 20 (1989): 173-89.

Russell, George H., and Venetia Nathan. "A Piers Plowman Manuscript in the Huntington Library.” Huntington Library Quarterly 26 (1963): II9-30.

Samuels, M. L. "Langland's Dialect." $M E$ 54 (1985): 232-47.

Sandler, Lucy Freeman. "A Note on the Illuminators of the Bohun Manuscripts." Speculum 60 (1985): 364-72.

Sargent, Michael G. "What Do the Numbers Mean? A Textual Critic's Observations on Some Patterns of Middle English Manuscript 
Transmission." In Design and Distribution of Late Medieval Manuscripts in England, ed. Margaret Connolly and Linne R. Mooney. York: York Medieval Press, 2008. 205-44.

Sayce, Olive. "Chaucer's 'Retractions': The Conclusion of the Canterbury Tales and Its Place in Literary Tradition." $M A E_{40}$ (I97I): 230-48.

Scanlon, Larry. "Langland, Apocalypse and the Early Modern Editor." In Reading the Medieval in Early Modern England, ed. Gordon McMullan and David Matthews. Cambridge: Cambridge University Press, 2007. 5I-73.

Scase, Wendy. "Dauy Dycars Dreame and Robert Crowley's Prints of Piers Plowman." YLS 2I (2007): I7I-98.

"Writing and the Plowman: Langland and Literacy." YLS 9 (I995): I2I-3I.

Schmidt, A. V. C. The Clerkly Maker: Langland's Poetic Art. Cambridge: D. S. Brewer, 1987.

Schoenbaum, S. “A New Vertue Shakespeare Portrait.” Shakespeare Quarterly 28 (1977): 85-6.

Shakespeare's Lives. New edn. Oxford: Clarendon, I99I.

Sherbo, Arthur. "Samuel Pegge, Thomas Holt White, and Piers Plowman." YLS I (1987): I22-8.

Sherman, William H. Used Books: Marking Readers in Renaissance England. Philadelphia: University of Pennsylvania Press, 2008.

Silverstone. "The Vision of Pierce Plowman." N\&Q 2nd ser. 6, I42 (I858): 229-30.

Simpson, James. "'After Craftes Conseil clotheth yow and fede': Langland and London City Politics." In England in the Fourteenth Century: Proceedings of the I99I Harlaxton Symposium, ed. Nicholas Rogers. Stamford: P. Watkins, 1993. I09-27.

Piers Plowman: An Introduction to the B-Text. New York: Longman, 1990.

Reform and Cultural Revolution, I350-I547. Vol. 2 of The Oxford English Literary History, gen. ed. Jonathan Bate. Oxford: Oxford University Press, 2002.

"Saving Satire after Arundel's Constitutions: John Audelay's Marcol and Solomon." In Text and Controversy from Wyclif to Bale: Essays in Honour of Anne Hudson, ed. Helen Barr and Ann M. Hutchison. Turnhout: Brepols, 2005. 387-404.

Skeat, Walter W. "Age of the World II." N\&Q 4th ser. 3 (I869): 203.

"Quotations Wanted." N\&Q 3rd ser. Io (I866): 290-I.

Smith, Macklin. "Langland's Unruly Caesura." YLS 22 (2008): 57-IOI.

Somerset, Fiona. "Al pe comonys with o voys atonys': Multilingual Latin and Vernacular Voice in Piers Plowman." YLS I9 (2005): I07-36.

Spearing, A. C. Criticism and Medieval Poetry. London: Edward Arnold, 1964.

Stanbury, Sarah. "Vernacular Nostalgia and The Cambridge History of Medieval English Literature." Texas Studies in Literature and Language 44 (2002): 92-107.

Steiner, Emily. Documentary Culture and the Making of Medieval English Literature. Cambridge: Cambridge University Press, 2003.

Summit, Jennifer. Memory's Library: Medieval Books in Early Modern England. Chicago: University of Chicago Press, 2008. 
Szittya, Penn R. The Antifraternal Tradition in Medieval Literature. Princeton: Princeton University Press, 1986.

Taylor, Barry. "Medieval Proverb Collections: The West European Tradition." Journal of the Warburg and Courtauld Institutes 55 (1992): 19-35.

Thomas, Keith. Religion and the Decline of Magic: Studies in Popular Beliefs in Sixteenth- and Seventeenth-Century England. London: Weidenfeld and Nicolson, 1972.

Thompson, John J. “Bishop Thomas Percy's Contributions to Langland Scholarship: Two Annotated Piers Plowman Prints in Belfast." In The Medieval Book and a Modern Collector: Essays in Honour of Toshiyuki Takamiya, ed. Takami Matsuda, Richard A. Linenthal, and John Scahill. Woodbridge: D. S. Brewer, 2004. 45I-9.

Turville-Petre, Thorlac. The Alliterative Revival. Cambridge: D. S. Brewer, 1977. Review of Galloway, Penn Commentary. YLS 20 (2006): 23I-34.

"Sir Adrian Fortescue and his Copy of Piers Plowman." YLS I4 (2000): 29-48.

Uhart, Marie-Claire. "The Early Reception of Piers Plowman." Ph.D. diss., University of Leicester, 1986.

Vickers, Brian. Shakespeare, A Lover's Complaint, and John Davies of Hereford. Cambridge: Cambridge University Press, 2007.

Wallace, David. Premodern Places: Calais to Surinam, Chaucer to Aphra Behn. Oxford: Blackwell, 2004.

Warner, Lawrence. "The Gentleman's Piers Plowman: John Mitford and his Annotated Copy of the 1550 Edition of William Langland's Great Poem." The La Trobe Journal 84 (2009): IO4-I2. Www.slv.vic.gov.au/latrobejournal/ issue/latrobe-84/tI-g-tio.html.

"Jesus the Jouster: The Christ-Knight and Medieval Theories of Atonement in Piers Plowman and the 'Round Table' Sermons." YLS Io (1996): 129-43.

"John But and the Other Works that Will Wrought (Piers Plowman A XII IOI-2)." N\&Q 52 (2005): I3-I8.

"Latin Verses by John Gower and 'John of Bridlington' in a Piers Plowman Manuscript (BL Add. 35287)." N\&QQ 55 (2008): I27-3I.

The Lost History of Piers Plowman: The Earliest Transmission of Langland's Work. Philadelphia: University of Pennsylvania Press, 2011.

Warren, Ann K. Anchorites and Their Patrons in Medieval England. Berkeley: University of California Press, 1985.

Wenzel, Siegfried. Latin Sermon Collections from Later Medieval England. Cambridge: Cambridge University Press, 2005.

Macaronic Sermons: Bilingualism and Preaching in Late-Medieval England. Ann Arbor: University of Michigan Press, I994.

Wiggins, Alison. "What Did Renaissance Readers Write in their Printed Copies of Chaucer?" The Library 7th ser. 9 (2008): 3-36.

Williams, Arnold. "Relations between the Mendicant Friars and the Secular Clergy in England in the Later Fourteenth Century." Annuale Mediaevale I (1960): 22-95. 
Wilson, Edward. "A Middle English Verse Sermon in the Winchester Anthology." N\&Q n.s. 46 (1999): 17-20.

"A Newly Identified Copy of The ABC of Aristotle in "The Winchester Anthology." N\&Q n.s. 47 (2000): 296.

"A Newly Identified Middle English Lyric in 'The Winchester Anthology'." NorQ n.s. 45 (1998): 430.

Wimsatt, James I. Chaucer and the Poems of "Ch". Woodbridge: D. S. Brewer, 1982.

Wittig, Joseph S. "Culture Wars' and the Persona in Piers Plowman." YLS I5 (200I): 167-95.

Zeeman, Nicolette. "Tales of Piers and Perceval: Piers Plowman and the Grail Romances." YLS 22 (2008): 199-236. 


\section{Index of manuscripts, early printed books, annotated books, and portraits}

MSS mentioned only in passing are not indexed. Aberystwyth, National Library of Wales

MS Hengwrt 154 (Peniarth 392D): Canterbury Tales, with Latin marginal glosses at the Clerk's Tale and Wife of Bath's Prologue. 53

MS 733B: Piers Plowman A/C splice, witnessing to the "ur-C" stage. www.llgc.org.uk/index.php? id=piersplowmannlwms733b. I8, 49, 53, I77

Ann Arbor, University of Michigan Library

PR2010.C95 I550: a $\mathrm{Cr}^{3}$ in which three hands debate the authorship of the poem. I85

Austin, Texas, University of Texas Library

Q PR I850 I532: I532 Thynne edition of Chaucer with MS copy of The Plowman's Tale added. I84

Bethlehem, Pennsylvania, Lehigh University

82I.I L265p I550: $\mathrm{Cr}^{\mathrm{I}}$, annotated by Joseph Ritson. http://digital.lib.lehigh.edu/ cdm4/eb_viewer.php?ptr=IO27. 8-II, I43-5, I66

828.I L256p 550a: $\mathrm{Cr}^{2}$. http://digital.lib.lehigh. edu/cdm4/eb_viewer.php?ptr=770. 170

Boston Public Library

G.406.32: $\mathrm{Cr}^{\mathrm{I}}$; sig. $\mathrm{Gg}$ and preliminaries supplied in MS facsimile. I7

Cambridge, Mass., Harvard University Library

Widener Harvard Depository I0454.I7: Ritson's Bibliographia Poetica, annotated by Frederick Madden. I42

Cambridge University Library

Additional MS 4325: Piers Plowman C, acquired by the library in 1905 . 102

MS Dd.I.I7: includes Piers Plowman B; perhaps associated with Austin York library. 35-6, 102, 176

MS Dd.3.I3: Piers Plowman C, consulted by John Taylor. IO2-4
MS Ff.5.35: Piers Plowman C, exemplar for John Cok and Walter Skeat. 53, 64, 68, IO2, I47

MS Gg.4.3I: Piers Plowman B, c.I540s, "The Prophecies of Piers Plowman.” 58, 78-9, 8I, 84, IO2, I32, I7I, I73

MS Ll.4.I4: Piers Plowman B with additional Latin lines and sixteenth-century glossary consulted by Robert Crowley (?) and John Taylor. 53, 60-2, 94, I02, I63, I73, I76

Syn. 2.56.2: Stow edition of Chaucer littered with annotations, including a passage from Troilus and Criseyde. 134

Syn. 7.55.I2: $\mathrm{Cr}^{\mathrm{I}}$, heavily annotated by a sixteenth-century hand who provides an extensive index, and later owned by one Elizabeth Johnson who believed Chaucer to be the author of Piers Plowman. 9, I33-4

Cambridge, Corpus Christi College

MS 293: Piers Plowman C, collated against a Rogers edition by James Nasmith; consulted by John Taylor. 8, I3, IO2, 176

Cambridge, Gonville and Caius College Library

MS 201/I07: transcription of Piers Plowman based on Rogers's I56I edition. I6, 78, IO2, I46

MS 669*/646: includes John Cok's fifteenth-century excerpts from Piers Plowman. 68

Cambridge, King's College Library

MS I3: includes William of Palerne. ${ }^{4} 8$ Cambridge, Trinity College Library

MS B.I4.I9: Pricking of Love with Stephan Batman annotation. 158

MS B.I5.I7: Piers Plowman B in London dialect. 25, I49, 176

MS R.2.36: transcript of the Ilchester MS for Skeat's edition of the C version. I6, 42 
Cambridge, Trinity College Library (cont.)

MS R.3.I4: Piers Plowman A + B 6 "hunger prophecy" by ?Stephan Batman. I69, I76, I84

MS R.I4.9: includes statistics on the age of the world.

Dallas, Southern Methodist University

007I2: $\mathrm{Cr}^{3}$, final leaf supplied in MS facsimile. I7

Dublin, Trinity College Library

MS 2I2 (D.4.I): Piers Plowman C with authorial ascription; no known provenance between I688 and I745. 23, IO 4

Durham, North Carolina, Duke University Library

D.9 L282V c.I: $\mathrm{Cr}^{3}$, annotated by an anonymous nineteenth-century reader. 9

Haverford, Pennsylvania, Haverford College

Magill Library 96: Rogers I56I edition, annotated by Richard Farmer. 93, 99, I43, I86

Kew, National Archives

Eior/516/9: includes excerpt of Piers Plowman lines I-4. I7, 67, I47

Liverpool University Library

MS F.4.8: Piers Plowman A-C; discussion of authorship on final page. 185

London, British Library

Additional MS 6399A: includes Frederick Page's transcription of a passage from Piers Plowman. I23, I82

I0285: Joseph Ritson's notebook. 7-II, I38-9, I42

I0574: Piers Plowman B, final 32 lines supplied by Dr. Adam Clarke (I760-I832). I7

22903: includes letter of William Dupré. I79

29490: transcription of CUL MS Ff.5.35 for Skeat's edition of C. I6

34360: Lydgate and Chaucer, owned by John Stow and John Taylor. I02, I76

34779: Piers Plowman C, additions in a later hand. 104, 169

35287: Piers Plowman B, includes Latin tags by Gower and John of Bridlington, and shared variants with Sloane 2578's "hunger prophecy." I8, I55, I7I, I76-7 35663: includes letter of William Dupré. I79 38178: MS of the Canterbury Tales copied by John Urry. 90

46706: includes letter of William Dupré. 179

60577: The Winchester Anthology, including "two monks' heads" prophecy. www.bl.uk/catalogues/ illuminatedmanuscripts $/>60577.20$, 73-9, 8I, 83-5, I32, I66-7

MS Cotton Caligula A xi: Piers Plowman B-A-C; basis of Ritson's "B" group of MSS. 7-8, I44, I76

Vespasian B xvi: Piers Plowman C collated by Tyrwhitt. 7, I23, I36, I44, I74, I76, I82

MS Egerton 2864: Canterbury Tales with pacientes vincunt tag; purchased by Lowes at auction in 1784 . 17, 69-7I, $103-4$

MS Harley 207: The Banckett of Johan the Reve unto Piers Ploughman, Laurens labourer, Thomlyn tailyer and Hobb of the hille with other. 85

559: sixteenth-century political prophecies. 8I, I69

875: Piers Plowman A, with four headings by William Burrell. 7, 95-7, 135-7, 177

I239: Canterbury Tales with Latin taken into the Man of Law's Tale. I63

2376: Piers Plowman C, "translated" into another dialect; mined by Humfrey Wanley as evidence that Chaucer hid his identity in composing these "poems." 7 , 9, 25, I35-7, I49

3954: Piers Plowman B-A; consulted by Ritson who transcribed its unique conclusion. 7, 9-II

6041: Piers Plowman B-A-C, followed by Latin "quick brown fox" tag. 7-8, 57, I00

7055: includes Humfrey Wanley's account of the Spelman auction of I709/IO. IO4, 172

MS Royal 7 E Iv: John Bromyard's Summa Praedicantium. 164

I8 B xvir: Piers Plowman C, copied sixteenth century, consulted by Ritson. 7 , I32, I44

MS Sloane 59: includes John Malverne's Remedium contra Pestilentiam, on Dr. Taylor's list of "MSS of our author." IO3 2578: sixteenth-century political prophecies. I6-I7, 79-8I, 83-4, I69, I7I

C.6o.g.I2: Ritson's Bibliographia Poetica annotated by Edmond Malone. I4I

C.7I.c.29: $\mathrm{Cr}^{\mathrm{I}}$ collated by Thomas Tyrwhitt against MS Cotton Vespasian B XVI. I36, 174

G.I3I23: Haslewood biography of Ritson, annotated and interleaved by Haslewood. I42, I86

SCS 68: Catalogue for the I8Io Auction of Richard Gough's Library, including the Spelman MS, whose entry Manly and Rickert instead locate in a I75I catalogue. I75 
643.m.4: Urry's Works of Geoffrey Chaucer with annotations by Timothy Thomas. I72

679.e.26: Bibliotheca Askeva, with purchasers inscribed. I03, 174

London, Library of the Honourable Society of Lincoln's Inn

MS I50: includes Piers Plowman A; consulted by Ritson. 7

London, The London Library

Ant. (Shelfmark denotes a rare book published before I80o): Owen Rogers's I56I edition of Piers Plowman, inscribed by Sarah King in the nineteenth century. I34

London, National Portrait Gallery

NPG I: The "Chandos" Portrait of Shakespeare, once owned by Robert Keck. I07-8

NPG D25488: George Vertue's engraving of Shakespeare (I719). I07-IO

London, Society of Antiquaries

MS 687: includes Piers Plowman A and a fourline excerpt in another hand. 17, I47, I65

London, University of London Library

MS S.L. V.88: the "Ilchester" Manuscript, Piers Plowman C, copied by John Marchaunt of the London Guildhall, and used as exemplar by Skeat. 42, I03, I47, I $55-7$, I77

Longleat, Longleat House Library

MS so: Higden's Polychronicon, owned by Stow and Browne. 176

Los Angeles, UCLA Library

PR20Io AI I550: $\mathrm{Cr}^{\mathrm{I}}$, final leaves supplied in MS facsimile. I7

Melbourne, State Library of Victoria

RareS 82I.I5 V: $\mathrm{Cr}^{2}$ annotated by John Mitford. I2-I3

New Haven, Yale University, Beinecke Library

MS Osborn a.I8: Piers the Plowman's Exhortation to Catholic martyrs. 85

ID L 26 550c: $\mathrm{Cr}^{2}$, with list of Latin lines. I7, 69

ID L 26 550F: Rogers edition owned by Richard Harvey, I588. 83

Nottingham, University of Nottingham Library

MS Mi LM 2: includes Latin ditties inscribed by bored students. 162

Oxford, Balliol College Library

525.a.I: Rogers annotated by John Urry. 90-3

Oxford, Bodleian Library

MS Arch. Selden B 8: sixteenth-century political prophecies. 169

MS Ashmole I468: includes Piers Plowman A followed by Latin lines. 16, 55-7, 59-60, 67, I6I-2
MS Bodley 463: Pseudo-Ptolemy's Centiloquium with Latin line used in C. 65

649: macaronic sermons. I65

8I4: Piers Plowman C-A-B splice, in John Taylor's list of MSS. I7I, I76

85I: line from Piers Plowman among Latin items on front flyleaves; also includes " $\mathrm{Z}$ version" of Piers Plowman. 17, 67, I47-8, I65, 176

MS Digby IO2: Piers Plowman C, copied by a London Brewer. 157,176

145: Piers Plowman A-C, copied by Adrian Fortescue in I532. 85, IOO, I32, I34, I76

I7I: Piers Plowman A-C, inscribed by Stephan Batman. 176, I84

MS Douce I04: Piers Plowman C, illustrated; Douce reference to Dupré. 7, I23-6, I44, I77

227: the laws of Oberon, owned by William Dupré. II2, I22-3

302: poems by John Audelay. I53

319: Brunetto Latini; owned by William

Dupré. II2, I22-3, I79, I82

323: includes Piers Plowman A and William

Dupré's modernization. II6-23, I25-8, I43

MS Eng. poet. a.I: the Vernon MS, including Piers Plowman A. 7, I44

MS James 2, part I: excerpts of Piers Plowman $B$ made by Richard James in the seventeenth century. I6-I8, 68-9, I46, I76

MS Laud misc. 581: Piers Plowman B, in John Taylor's list of MSS. 176

656: includes Piers Plowman C, in John Taylor's list of MSS. 176

MS Rawlinson B 332: register of St. Alban's Abbey; misogynist maxim. I64

D 328: a collection of proverbs; misogynist maxim. 64

C 8I3: sixteenth-century political prophecies. 169

poetry 38: Piers Plowman B, owned by Thomas Hearne and Richard Rawlinson. I8, 98-9

poetry 137: Piers Plowman A, owned by Thomas Hearne and Richard Rawlinson, featuring variant reading in Prol.I noted by Philip Bliss. 98, I00, I77

MS Wood donat. 7: excerpts of Piers Plowman $B$ made by Gerard Langbaine in the seventeenth century. I6-I7, 68-9, I46, I7 6 
Oxford, Bodleian Library (cont.)

$4^{\circ}$ Rawlinson 272/273: $\mathrm{Cr}^{\mathrm{I}}$ now in the two volumes, signed by John Taylor and interleaved and annotated by William Burrell. 94-IOI

274: Rogers, interleaved and annotated by John Taylor. 94, 99, I02-3, I07, I43

275: Rogers owned by Hearne. 98

Douce L 195: Rogers in which a reader has mentioned Pope's copy. I45

L 205: $\mathrm{Cr}^{2}$ in which one Andrew Bostock engages in a running debate with the reformist glosses. 85

RR 36: Douce's copy of Bibliographia Poetica; letter from Ritson pasted in. 7

Oxford, Corpus Christi College

MS 20I: Piers Plowman B, included in John Taylor's list of MSS. I8, I02, I7I

Oxford, Oriel College Library

MS 79: Piers Plowman B with some extra Latin lines in the margins. 53, 60-2, IO2-3, I63, I76-7

San Diego, University of California at San Diego Library

PR2oro.C76 I550: $\mathrm{Cr}^{3}$ inscribed by Thomas Warton. http://hdl.handle.net/2027/ ucI.31822038199956. I70

San Marino, Huntington Library

MS Ellesmere 26 C 9: Canterbury Tales, with Latin marginal glosses at the Clerk's Tale and Wife of Bath's Prologue. 53

MS Hm II4: "Spelman" MS with conflated Piers Plowman and other works; owned by Henry Spelman, Lord Weymouth, and John Taylor and consulted by John Urry and William Burrell in eighteenth century. 2I, 87-93, 95-9, IOI-2, IO4-5, I6I

I28: Piers Plowman B used as exemplar by Dr. Adam Clarke; includes excerpt in different hand. I7, I47, I7I

137: Piers Plowman C, with Latin ditty on final folio. 56, I57

I43: Piers Plowman C, deemed to have direct connection to Langland by some, with annotations in early hand. $17,40-1,48$, $64,67,156$

88317: sole extant copy of $c .1533$ printed edition of The Plowman's Tale. I32, I84

Tokyo, collection of Toshiyo Takamiya

MS 23: Piers Plowman B from c.I550, olim Sion College MS Arc. L.4O 2/E. 78

Copy of $\mathrm{Cr}^{2}$, owned by Robert Southey. IO6-7

Washington, D.C., Folger Shakespeare Library

FPsi3: the "Felton" Shakespeare portrait, favored by George Steevens. I09-IO, I78

STC 19906: $\mathrm{Cr}^{\mathrm{I}}$ in which subsequent owners ascribe the poem to both John Malverne and Robert Langland. http://luna.folger.edu/luna/servlet/s/ Io62dp. I85

York, University of York, Borthwick Institute for Archives

Additional MS 196: Piers Plowman A-C; in private hands and placed on deposit at York in 2006. 2, 53 


\section{General index}

Abbey of the Holy Ghost, II6

Adams, Robert, 34-5, 42

Alderson, William, 9I-2

Alexander A, 24

Alexander and Dindimus, 24

Alford, John A., 54, 57-8, 62-3, 65-6, I64

and $\mathrm{M}$. Teresa Tavormina, I8I

Allen, Bessie, 4I, I57, I59

Ames, Joseph, I02-3, 176

anchorites see Piers Plowman, characters, themes, and motifs

Ancrene Wisse, 30-I

archive, as repository of documents, I, 6, 8, 98, IO6, II5, I4O

archive fever, I, 7, 44, I29, I40

archons, I, I5, I7-I9, 86

of the Langland archive, 4

Askew, Anthony, 98-9, IOI, I03, I74, 176

Atonement (see also Piers Plowman, characters, themes, and motifs)

as series of documents, 30

beguiling the beguiler, 32

Christ-knight, 32-3

devil's rights, 32

disguise, 28, 30-2

Audelay, John, 34, I53

Augustine, St., Bp of Hippo, 32

author, concept of, I

authorial attribution, 22-6, 36 see also Piers Plowman, authorship and production

Auvergne, Peter of, 63

Baldwin, Anna P., I64, I83

Bale, John, 84, I29, I33, I37, I84

Banckett of Johan the Reve unto Piers Ploughman ..., 85

Barnes, Joshua, 9I

Barney, Stephen A., 65

Barr, Helen, 62, 167

Bart, Patricia, 172
Barthélemy, Jean-Jacques, III

Batman, Stephan, 43, I32-3, I69, I84

Beauchamp, Thomas, eleventh earl of Warwick (I314-69), 34-5, I54

Beauchamp, Thomas, twelfth earl of Warwick (d. I4OI), 34-5

Bedford, Grosvenor, 106

Bedford, Horace Walpole, I07

Bedford, William, 174

Bennett, J. A. W., $5 \mathrm{I}$

Bennett, Michael, 34-5, I53

Benson, C. David, 20, I47

Bernard, Edward, I04

"best text," 36, 38, 40, 46, 52

Bible

Gen. I.26, 162

Isaiah $62: 4,56$

John 3:13, I6I

Judith 6:15, 66

Luke I4:20, 62

Luke I8:I4, I6I

Matt. 5:I9, I6I

Matt. 6:2, I6I

Psalm 68:9, I62

Rom. I2:I5, I6I

Rom. I2:I9, I62

Bliss, Philip, Iо0, Iо2

Boaden, James, I08-9, 178

Bodleian Library, Oxford University, 88, 98-I0o, IO5, II7, I75

Bohun, Alice, I54

Bohun, Humphrey de, second earl of Hereford, 34

Bohun, Humphrey de, fourth earl of Hereford, 34

Bohun, Humphrey de, sixth earl of Hereford, 22, 34-5

Bohun, Humphrey de, seventh earl of Hereford, I54

Bohun, William de, 34, I54

Bokenham, Osbern, 22

Bowden, Betsy, II9, I82 
Bowers, John M., I39, I47, I57

Brembre, Nicholas, 44-5, 5I

Brewer, Charlotte, I5, 4I, I59

Brewer, Derek, II9, I82

Brinton, Thomas, 75

British Museum, 88, I00-I, II9, I23

Bromyard, John, 66, 69

Browne, William, 176

Brunetto Latini, III-I2, II5-I7, I22

Brynstan, John, 75-8, 8I, 83-4

Bunt, G. H. V., I49-50

Buriton, John, 76-7

Burrell, William, I7, 94-7, IOI, I05, I35, I74 as editor and textual scholar, II8 as non-editor, IOO as student of John Taylor, 95, IOI

Burrow, John, 58

But, John, 23, 29, 7I

Butterfield, Ardis, 54

Calabrese, Michael, 64

Cambridge University Library, 88, 93

Cannon, Christopher, 66

Carley, James, I3I, I84

Carnegy, F. A. R., 46-7, 52, I60

Carpenter, John, 88

Carteret, John, second Earl Granville, 98

Cassian, John, 28

Cato, 56

Chalmers, George, IIO, II2-I5

employed by the earl of Liverpool, II2 see also Malone, Edmond

Chandos portrait of Shakespeare, I07-IO, I79

Chatterton, Thomas, I08, II5-I6, I37-8, I80

Chaucer, Geoffrey, 23, IO2

as author of Piers Plowman, 2I, 130-9

Canterbury Tales, II, I8, 6I, 69, 90, IO3, I3I, I35 Clerk's Tale, 53

editions see Manly, John M., and Edith

Rickert; Riverside Chaucer; Thynne,

William; Tyrwhitt, Thomas; Urry, John

Franklin's Tale, 69, 7I

Langland, absurdity of comparison with, 92, I30 Langland, obligatory conjunction with, I30

Legend of Good Women, 30

Man of Law's Tale, $\mathrm{I}_{3}$

modernizations see Dryden, John; "Miller of Trompington” (anon., publ. I7I5); Pope,

Alexander

poems of "Ch," 22

Romaunt of the Rose, I8, 48, I34, I85

Troilus and Criseyde, 89-90, 95, I34, I66, I85 Wife of Bath's Prologue, 53

Chism, Christine, 26, 39

Christ Church Oxford, 93
Churchyard, Thomas, 79, I69

Clarke, Adam, I7

Clay, Mary Rotha, 48

Cok, John, 68-9

Coleridge, Samuel Taylor, Io6

Constantine, John (cordwainer), 44-5

Constantine of Pisa, 65

Cooper, Elizabeth, II7

Corfe castle, 44-6, 50, I60

Corser, Thomas, I8I

Cotton, Robert, 88

Courtenay, William, Archbp., 48

Croft, Herbert, II5-I6

Cromwell, Thomas, 74, 77, 85

Crowley, Robert, 8I-4, I39

and Kett's Rebellion, I70

and prophecy, I7O

attribution of Piers Plowman to "Robert

Langland," I33

consultation of MSS, 84, 92

glosses to Piers Plowman, reformist character of, 84 , I7I

three 1550 editions of Piers Plowman, 8-9, 72, $79,87, \mathrm{I} 23$

Dackomb, Thomas, 73, I67

Dane, Joseph A., I84

Dante Alighieri, 65

Dart, John, 9I

de Grazia, Margreta, I07, II3-I4, I78, I80

Derrida, Jacques, I-4, I6, 57, 59-60

dialectology, 40

DiMarco, Vincent, 8, I2, II8, I42

Dobson, John (vicar), 75

Dodsthorp (owner of Bodley 85I), 67

Donaldson, E. Talbot, 7, 50, II8, I42

Douce, Francis, I43

and Joseph Ritson, 7, I38, I42

and William Dupré, II7, II9

bequest to the Bodleian, IOO, III see also Dupré, William

Doyle, A. I., I56

Droeshout engraving of Shakespeare, IO9-IO

Dryden, John, II9, I32, I34, I39, I84

Dupré, William, I06, I08, II4-I6, I79

and Croft's Love and Madness, II5-I6

and Francis Douce, $\mathrm{I} 2 \mathrm{I}-7$

and Piers Plowman, II8-2I, I8I

as manuscript collector, III, II4

as pilgrim figure from Douce IO4, I24-5 attempt to sell MSS to earl of Liverpool, II2

forgeries of Brunetto in Monthly Magazine, 5, III

prisoner during French wars (I794), II2 
translation of Margaret of Valois, I23-4 see also Chalmers, George; Chatterton, Thomas; Douce, Francis

Dyas, Dee, 28

Economou, George, II8

Edwards, A. S. G., IO3, I76

Ellis, Henry, II7, II9

Emmerson, Richard, 85

Entick, John, 9I

Erghome, John, 35 see also John of Bridlington's Prophecy

Esposito, Mario, III

evidence, concept of, I8, 24-6

fabrication, concept of, 5, 21, 36, 106, I08, I40

Farmer, Richard, 99, I38, I43, I73, I86 annotations in flyleaves of his Piers Plowman, 93, I37

Felton portrait of Shakespeare, I09-IO, I78

Fortescue, Adrian, 77, 85

Foucault, Michel, I, 4, 2I

French Revolution, IO7, II2, II4

Freud, Sigmund, I, 3-4, 57, 59

Fricher, Edith, Io6

Gaffney, Wilber, 32

Galloway, Andrew, 23, 40, I60

Gascoigne, George, 13

Gawain-poet, 23

Gentleman's Magazine, II-I5, 94, II7, I86

Gillespie, Alexandra, I3I, I84

Giunta, Claudio, III, II5, I24, I82

Goldberg, Brian, II6

Gough, Richard, 99-IOI, II4

Gower, John, I8, 23, 53, 60-I

Gradon, Pamela, I85

Greetham, David C., I

Greg, W. W., I07

Guillaume de Palerne, 22-3, 27-9, 3I, 33

Hailey, R. Carter, 84, I43, I74

Hanna, Ralph, 30, I4I, I46

Harbin, George, 90

Hardyng, John, 88, IO4

Harley, Edward, earl of Oxford, 88, 95-6

Harley, Margaret, duchess of Portland, 97

Harris, Kate, 90

Harvey, John, 83

Harvey, Richard, 83

Haslewood, Joseph, I42

Hearne, Thomas, 99

Henry VIII, 77, 85, I29

Heywood, Ellis, 73
Higden, Ranulph, 60, 63-4

Holloway, Julia Bolton, I79

Holyngborne, William, I62

Horobin, Simon, 39-40, 48, 91, I33, I57, 176

Hudson, Anne, 72, 85, I7I

Ilchester family, I03, I77

"In the yere of our lorde god I554," 8I

Ireland, William-Henry, IO8-9, II2-I3, II5, I38, I78, I80

see also Chalmers, George; Croft, Herbert; Dupré, William

Irvine, Annie S., I84

James, Richard, 68, I46

Jansen [Jaech], Sharon, 79-80, I69, I7I

Jefferson, Judith, 58

Jeffrey, David Lyle, 28

Jensen, Wilhelm, 3

John of Bridlington's Prophecy, 67

line from, in Piers Plowman MS, I8 see also Erghome, John

Johnson, Elizabeth, I33-4, I39

Johnson, Samuel, 94

Johnston, Michael, I7I

Jones, Mike Rodman, I70

Joyce, James, 2, 4

Justice, Steven, 38-9, I56

Kane, George, 6, I9, 23-4, 26, 42, 53-4, 94, II8, I48, I62, I69, I7I

and E. Talbot Donaldson, I59, I63

Kantorowicz, Ernst, I79

Keck, Robert, I07-II, I79

Kelen, Sarah, I38, I70

Kett's Rebellion see Crowley, Robert

King, John N., 72, 84-5, I70

King, Sarah, I34

Lamb, Charles, I2

Langbaine, Gerard, 68

Langland archive, 4, II-I2, I9-2I, 26, 36, 49, 87-8, 99, I02, I04-5, I23, I29-3I, I40

and prophecy as inherently reformist, 72-3

arbitrary character of, $5 \mathrm{I}$

definition of, 2, IO4

first modern account of, by John Taylor, 99

Latin lines in, 53, 55, 57, 67, 7I

MS variation in, 93

Romanticism, separate from, Io 6

Langland, Robert see Piers Plowman, authorship and production

Langland, William (see also Piers Plowman, authorship and production; Rokele, William) 
Langland, William (cont.) and London, 38, 40-5 and Malvern region, 38-9, 50, I55, 160 as putative author of William of Palerne, 24-6 dialect, 25, 38, 40, 48, I55 "Long Will," arrest of, 35 metrical practices, I20, I50, I60

Lawler, Traugott, 58

Lawton, David A., 23, 28, I48-9

Leland, John, I29-32, I35, I43, I84

Leonines, 56, 61, 64, 66, I20

Lerer, Seth, I34, I85

Lestrange, Richard, 34

Letter-Book H, 46, I58

Lewis, C. S. see Ritson, Joseph

Ley, James, first earl of Marlborough, I77

Liverpool, earl of

classical scholar, II2

see also Chalmers, George; Dupré, William

London riots of $1384,20,38,42-5,50$

Longleat House, 89, 98 see also Thynne, Thomas, first Viscount Weymouth

Lowes (MS collector), IO3

Lydgate, John, IO2, I34

Lynford, Robert, I57

Machan, Tim William, I6I

McIntosh, Angus, 23

Macray, William Dunn, 99

Madden, Frederic, Ioo, I42

mal d'archive see archive fever

Malone, Edmond, 6, IO7-IO, II2-I5, I4I, I78, I8O

Malvern, John see Piers Plowman, authorship and production

Manly, John M., Is

and Edith Rickert, 98, IOI, I75

Marchaunt, John, 71, 88, I56-7

Margaret of Valois see Dupré, William

Marsh, George Perkins, I4-I5

Matilda (anchorite), 49, I59

Middleton, Anne, 39, I50, I56

"Miller of Trompington, Being an Exercise upon Chaucer's Reeve's Tale" (anon., publ. I7I5), II $9-20$, I 82

Mitchell, A. G., 46-50, I59

Mitford, John, II-I5, I9, I37-8, I86

Modern Language Association, I5

Monthly Magazine see Dupré, William; Southey, Robert

Mooney, Linne R., and Estelle Stubbs, 88, I56

Morell, Thomas, 9I

Mowbray, Thomas, 44

Mulder-Bakker, Anneke B., 49

Mum and the Sothsegger, 74
Nares, R. A., 28

Nasmith, James, 8-9, I3, I8, I45

newfangledness, 77, 83

Newton, Mary, IIs see also Chatterton, Thomas

Nichols, John, 94

Northampton, John, 44-6, 5I, I58

Oakden, J. P., 25

Osbarn, Richard, 88

Oxford, earl of see Harley, Edward, earl of Oxford

pacientes vincunt, 65-6, 7I

Page, Francis, 176

Page, Frederick, I7, I23

Parker, Matthew, Archbp., 44, I33, I69

pas, 3, I4I

passus, 3

Pates, Stella, 65

Paul, John E., 73

Pearsall, Derek, 28, 40, 5I, 65, 74, 80, I56

penance, 22, 28-30, 43, 49, 79

topos of regret, 30

Percy, Thomas, I2, 96, I43

Philip, Ian, I75

Piers Plowman A, passages cited

Prol.I-7, 27, 29, I52

Prol.I4, I5O

Prol.28-30, 47

Prol.35-7, 29

Prol.90-5, I73

I.8I-2, I52

I.I 62,67

2.3, 150

2.40-2, I53

$3.233 \alpha$, I6I

4.I5-I7, I47

5.I3-I4, 25

5.107, I2I

5.107-45, I2O-I

5.II2-I3, I2I

5.I27-8, I2I

5.I4O, I2I

7.3, 96

$7.68 \alpha$, I6I

$7.78,162$

7.133-4, 47

7.234-4a, 59

7.237-6I, I2I

9.I-9, II8

9.87, II8

I0.4I $\alpha, \mathrm{I} 62$

I0.5O, II 8

I0.98, I6I

IO.IO3-8 $\alpha, 63$ 
IO.I20 $\alpha, 16$ I IO.I35-8, 47 II.If., 64 , II8 II.I93 $\alpha$, I6I II.I96 $\alpha$, I6I II. 255,162 II. $263 \alpha$, I6I I2.IOI, 29, I49

Piers Plowman B, passages cited

Prol.I4, I5O

Prol.28-30, 47

Prol.I32f., I73

I. 79,58

I.I2I, 90

I.I4I $\alpha, 69$, I66

$5.269 \alpha-\beta, 166$

$5.440 \alpha, 69,166$

$6.3,96$

6.I45, 47

$6.253,58$

6.32I-3I, 74, 80

$6.328,8 \mathrm{I}$

8.104-8, 96

8.127-9, I37

9.186 $\alpha-\beta, 166$

I0.195-6, I66

I0.256 $\alpha$, I 66

I0.26I $\alpha$, I 66

I0.266 $\alpha-\beta$, I 66

I0.322-5, 78 , 80

I0. $342 \alpha$, I 66

I0.392-4, 29

II. $4 \mathrm{I} 6 \alpha, \mathrm{I} 66$

II. $58 \alpha$, I 66

II.IO6 $\alpha$, I 66

II.23I, I 66

II. $269 \alpha$, I 66

II.28I $\alpha, \mathrm{I} 66$

I2.50 $\alpha, 166$

I2.65 $\alpha, \mathrm{I} 66$

I2.207 $\alpha, \mathrm{I} 66$

I3. $45 \alpha$, I 66

I3.I35 $\alpha, 65$, I 66

I3.I7I $\alpha, 65$

I3.203-4, I52

$\mathrm{I} 3.426 \propto, \mathrm{I} 66$

I4.I-4, 62

I $4.33 \alpha, 65, \mathrm{I} 66$

I4.54, 65

I4. $60 \alpha$, I 66

I4.276, I66

I5.39 $\alpha$, I 66

I5.I52, 24, 35

I5.2I3-I4, 47

I5.268, 65
I5.343 $\alpha, 69$, I 66

I5.4I7-I8, 47

I5.557-6I, 60

I5. $598 \alpha, 65$

I6.93-5, 6I

I7.2-5, $3 \mathrm{I}$

I7.34I $\alpha$, I 66

I8.I, 28

I8.22-6, 32

I8.78-86, 32

I8.I86, $3 \mathrm{I}$

I8. 356,32

I9.I-20.386, 58

I9.252-7, $5 \mathrm{I}$

I9.470-4, 78

Piers Plowman C, passages cited

Prol.I-4, I7

Prol.I-I3, 8

Prol.2, 48

Prol.3, 48

Prol.30-2, 47

Prol.95-I24, 49

I.II2-25, 93

I.I84, 67

3.77/87-II4, 42, 5I

3.108-I4, 44

$3 . \mathrm{I} 4 \mathrm{I}-3,45-5 \mathrm{O}$

3.I4I-6, $5 \mathrm{I}$

3.188-90, 65

3.1900, 64

3.404, 48

3.422, I59

5.I-IO4, 29, 39, 42

$5.2,48$

$5.44,39$

8.146, 47

I4.28-34, 65

I5. 137,65

I5.156, 65

$15.253,65$

I6.116, 68

I6.I82-20I $\propto, 68$

I6.286-97, 42

I7.53-4, 59

I7.220-4, 60

2I.96-I07, I64

Piers Plowman Electronic Archive, I5-19, I46

Piers Plowman manuscripts, versions, and early scholarship (see also the Index of

manuscripts, early printed books, annotated books, and portraits)

'i'- or X-group of C, 40-I

early editions see Crowley, Robert; Whitaker,

Thomas; Wright, Thomas

lists of, I5-19, 59, 69, 7I, 94, I02 
Piers Plowman manuscripts, versions, and early scholarship (cont.)

opelond vs. upon london crux (C 5.44) see Piers

Plowman $\mathrm{C}$, passages cited

P-group of C, 39-4O, 46, I57

rubrics, 56-8, I36, I62

set vs. soft crux in line I, 9, IOO, IO2, I23, I43

variation in, 6, 8, II, I3-I5, 93, IO5

wordlists, 9, I3

$Z$ version, as earliest see Piers Plowman $Z$

Piers Plowman Z, 67

as Langland's first version, 22, I48

terminus a quo, I49

see also the Index of manuscripts, early printed books, annotated books, and portraits, s.v.

Oxford, Bodleian Library, MS Bodley 85I

Piers Plowman, authorship and production

(see also Langland, William; Rokele,

William; William of Palerne)

A as final version, 22, I48

acrostic in B I5.152, 24, 35

ascription in Trinity MS, 23

B passus 19-20's origins in C, 42

$\mathrm{C}$ as retreat, 38-9, I55

concordance method, 62

French, role of, 23, 25

"John Malvern," 9, 94, I03, I33-7

Latinity, role of, 53-5, 58-67

localization, xii, 20, 36-52

loose sheets, $5 \mathrm{I}$

multiple authorship debates, I4-I5

"Robert Langland," 9, I33-9

"Will/William," 25, I35-9

Piers Plowman, characters, themes, and motifs

abbot of Abingdon, 72, 78-9

anchorites, 46-9, I59

archive of texts, 3, 31

Christ-knight see Atonement

crafts and guilds, 50

Davy the Dyker, 72; see also Churchyard,

Thomas; "In the yere of our lorde god I554"

disguise, 28, 32

Donation of Constantine, 60

friars, 29, 35-6, II8

Gluttony, 56

Haukyn, 62

Imagynatif, 65

Meed, 45-51, 65

opelond, 39, 42, 50

pilgrim, I25

place, 37

political prophecy, 74, 79

regraterie, 43-4, $5 \mathrm{I}$

revelation and atonement see Atonement

riddling, 36
Piers Plowman, reception of (see also Audelay, John) as prophecy of the advent of the Protestant era, $72,79,82,84$

excerpting, practice of, I6, I8, 67-7I, I47

in Romantic era see Southey, Robert

modernizations of, II8

Plowman's Tale, I3I, I84

Pope, Alexander, xii, I3, II4, II9-20, I45

preaching, 58, 66-7; see also Brinton, Thomas; Brynstan, John

Pressly, William L., I78

Price, Richard, I3

Prick of Conscience, I8

Pricking of Love, 158

prophecy see Piers Plowman, characters, themes, and motifs; Piers Plowman, reception of

proverbs, 64-7, I64

Pseudo-Ptolemy, 65

Pugh, Ralph, 48

“quick brown fox," 57

Rawlinson, Richard, 99, I74

Rice, Joanne, 69, I66

Rigg, A. G., 67, 165

Ritson, Joseph, I2, I7, I9, 93, I02, I39, I4I-2

anthologies of Piers Plowman, II7, I82

C. S. Lewis school of Langland criticism, II, IOO

irascibility, 6-7, 92

lists of words and memorable particulars in

Piers Plowman, 9, 13

madness, 7, I29

on the authorship of Piers Plowman, I2, I36-9

on the versions of Piers Plowman, 6-II, I3, IOO

Urry's Chaucer as pompous, inaccurate and licentious, 92

vegetarianism, 7, 138

see also Douce, Francis; Piers Plowman, reception of; the Index of manuscripts, early printed books, annotated books, and portraits, s.v. Bethlehem, Pennsylvania, Lehigh University

Riverside Chaucer, 69, 92, I73

Rogers, Owen, I56I edition of Piers Plowman, 8-9, I3, I6, 78

Rokele, William, 23, 34-5

Rolle, Richard, 68

Rowe, Nicholas, II4

Russell, George, 68

and George Kane, 39, 4I, 49, 68, I47, I56-60

and Venetia Nathan, 93

Samuels, M. L., 38, 40, I55

Sayce, Olive, 30 
Scanlon, Larry, 84

Scase, Wendy, 80, I69

Schmidt, A. V. C., I6, 23, 60, 65, 94, II8, I57, I83

Schoenbaum, Samuel, I07, 178

Shakespeare, William

editions of see Farmer, Richard; Greg, W. W.; Malone, Edmond; Pope, Alexander; Rowe,

Nicholas

forgeries of see Chalmers, George; Ireland, William-Henry; Malone, Edmond

legends about, II4

Lover's Complaint, 22

Polonius, I79

portraits of see Chandos portrait of

Shakespeare; Droeshout engraving of

Shakespeare; Felton portrait of Shakespeare;

Keck, Robert; Vertue, George

Sherbo, Arthur, I44

Sherman, William, I4O

Siege of Jerusalem, 25

Simpson, James, 42, 50-I, 83, I29, I58, I60

Skeat, William W., 27, 37, 39, 42, 46, 50, 56, 63, 65, II9, I47, I55

Somerset, Fiona, 58

Southey, Robert, I06-7, II5-I7, I78

Spearing, A. C., 66

Spelman, Henry, 88-90, 93, 95, IOI, IO4-5, I77

Spurgeon, Caroline, I35

St. Swithun's Benedictine Priory, 73, 76-7

Stafford, Hugh, I54

Stafford, Ralph, 35, 44, I54

Stanbury, Sarah, 53

Steevens, George, I09, I78-9

Steiner, Emily, 3, 30

Stow, John, 9I, IO2, I33, I76

Summit, Jennifer, 87

Takamiya, Toshi, I07, I78

Taylor, John

and William Burrell see Burrell, William

auction of his collection see Askew, Anthony

Cambridge University Librarian, 94

Carteret/Thynne family, friendship with see Carteret, John, second Earl Granville

collector of Middle English MSS, IO2

dullness of see Johnson, Samuel

Harley family, friendship with see Harley, Edward, earl of Oxford; Harley, Margaret, duchess of Portland

list of "MSS Copyes of our Author," 94, IO2-3 on authorship of Piers Plowman, 94, I03, I34 owner of Huntington Hm II4, 88, 93, 98, $\mathrm{IO}_{2}$ owner of ?lost MS of Piers Plowman, IO2-4 pains taken with Piers Plowman in I730, 93

Testament of Job, I64 textual historicism, concept of, 50-2

Thomas, Keith, 75

Thomas, Timothy, 89, 92

Thynne, Francis, I32

Thynne, Henry Frederick, 98

Thynne, Thomas, first Viscount Weymouth, 88-90, 95-8, 104

Thynne, Thomas, third Viscount Weymouth, 98, IOI-2

Thynne, William, 89, I3I

Todd, William, 74

topos of regret see penance

Turville-Petre, Thorlac, 26-7, I50

Tyler, Elizabeth, Io6

Tyrwhitt, Thomas, I3, I5, I7, 9I-2, 96, I36-7, I39, I45

Uhart, Marie-Claire, I6I

Urry, John, I7, 96, 98, IOI, IO3, IO5 as editor and textual scholar, 89, 92, 94, I00 Chaucer edition as "worst ever published," 9I-2

Christ Church, edition as fund-raiser for, 89

Homer, devils' fall in Piers Plowman compared with, 9I

MS variation, recognition of, 92-3

Piers Plowman, collation of, from Spelman MS, 90-I, 93

Spelman MS, use of in editing Chaucer, 89

Weymouth's patronage of, 89-90

Usk, Thomas, 42

Vertue, George, I07, I79

Waldegrave, Richard, 35, 44, I54

Waldegrave, Warin, 35, 44-5

Wallace, David, 37

Walpole, Horace, IOI

Wanley, Humfrey, I04-5, I34-6, I39

Warren, Ann K., I59

Warren, Kate, II9

Wars of Alexander, 25

Warton, Thomas, I2-I3, II7-I8, I39, I43

Warwick, Guy de, 34

Watson, Andrew, 73

Watson, Katherine, I75

Way, William, 73, 76

Webbe, William, I2

Wenzel, Siegfried, 67

Westminster, Monk of, 44-6, 52

Weymouth, Lord see Thynne, Thomas, first Viscount Weymouth; Thynne, Thomas, third Viscount Weymouth

Whitaker, Thomas, I2-I4, 20, 87, I0O, I23

White, John, Bp., 73 
William of Palerne

animal skins, 27-8

dialect, 25

documents, $3 \mathrm{I}$

meter, I5O

revelation and disguise, 32-3

Willmott, Robert Aris, 130

Wilson, Edward, 76-7

Winchester Anthology see the Index of manuscripts, early printed books, annotated books, and portraits, s.v.

London, British Library Additional

MS 60577

wolf in sheep's clothing, 28

work (literary), concept of, I, 4

Wright, Thomas, II-I5, IOO, II7-2I, I23, I8I

Wyclif, John, 6o, I33

Yerushalmi, Yosef Hayim, 57, 60

Ypotis, II6 
I ROBIN KIRKPATRICK

Dante's Inferno: Difficulty and Dead Poetry

2 JEREMY TAMBLING

Dante and Difference: Writing in the Commedia

3 SIMON GAUNT

Troubadours and Irony

4 WENDY SCASE

Piers Plowman and the New Anticlericalism

5 JOSEPH DUGGAN

The Cantar De Mio Cid: Poetic Creation in its Economic and Social Contexts

6 RODERICK BEATON

The Medieval Greek Romance

7 KATHRYN KERBY-FULTON

Reformist Apocalypticism and Piers Plowman

8 ALISON MORGAN

Dante and the Medieval Other World

9 ECKEHARD SIMON (ed.)

The Theatre of Medieval Europe: New Research in Early Drama

IO MARY CARRUTHERS

The Book of Memory: A Study of Memory in Medieval Culture

II RITA COPELAND

Rhetoric, Hermeneutics and Translation in the Middle Ages: Academic

Traditions and Vernacular Texts

I2 DONALD MADDOX

The Arthurian Romances of Chrétien de Troyes: Once and Future Fictions

I3 NICHOLAS WATSON

Richard Rolle and the Invention of Authority

I4 STEVEN F. KRUGER

Dreaming in the Middle Ages

I5 BARBARA NOLAN

Chaucer and the Tradition of the "Roman Antique"

I6 SYlVia HUOT

The Romance of the Rose and its Medieval Readers: Interpretations, Reception, Manuscript Transmission 
I7 CAROL M. MEALE (ed.)

Women and Literature in Britain, II5O-I5OO

I8 HENRY ANSGAR KELLY

Ideas and Forms of Tragedy from Aristotle to the Middle Ages

I9 MARTIN IRVINE

The Making of Textual Culture: Grammatica and Literary Theory, 350-IIOO

20 LARRY SCANLON

Narrative, Authority and Power: The Medieval Exemplum and the

Chaucerian Tradition

2I ERIK KOOPER

Medieval Dutch Literature in its European Context

22 STEVEN BOTTERILL

Dante and the Mystical Tradition: Bernard of Clairvaux in the Commedia

23 PETER Biller AND ANNE HUDSON (eds.)

Heresy and Literacy, IOoO-I530

24 CHRISTOPHER BASWELL

Virgil in Medieval England: Figuring the Aeneid from the Twelfth Century to Chaucer

25 JAMES SIMPSON

Sciences and Self in Medieval Poetry: Alan of Lille's Anticlaudianus and

John Gower's Confessio Amantis

26 JOYCE COLEMAN

Public Reading and the Reading Public in Late Medieval England and France

27 SUZANNE REYNOLDS

Medieval Reading: Grammar, Rhetoric and the Classical Text

28 CHARLOTTE BREWER

Editing Piers Plowman: The Evolution of the Text

29 WALTER HAUG

Vernacular Literary Theory in the Middle Ages: The German Tradition in its European Context

30 SARAH SPENCE

Texts and the Self in the Twelfth Century

3I EDWIN CRAUN

Lies, Slander and Obscenity in Medieval English Literature: Pastoral Rhetoric and the Deviant Speaker

32 PATRICIA E. GRIEVE

Floire and Blancheflor and the European Romance 
33 HUW PRYCE (ed.)

Literacy in Medieval Celtic Societies

34 MARY CARRUTHERS

The Craft of Thought: Meditation, Rhetoric, and the Making of Images, $400-1200$

35 BEATE SCHMOLKE-HASSELMAN

The Evolution of Arthurian Romance: The Verse Tradition from Chrétien to Froissart

36 SIÂN ECHARD

Arthurian Narrative in the Latin Tradition

37 FIONA SOMERSET

Clerical Discourse and Lay Audience in Late Medieval England

38 FLORENCE PERCIVAL

Chaucer's Legendary Good Women

39 CHRISTOPHER CANNON

The Making of Chaucer's English: A Study of Words

40 ROSALIND BROWN-GRANT

Christine de Pizan and the Moral Defence of Women: Reading Beyond Gender

4I RICHARD NEWHAUSER

The Early History of Greed: The Sin of Avarice in Early Medieval Thought and Literature

42 Margaret Clunies ROSS

Old Icelandic Literature and Society

43 DONALD MADDOX

Fictions of Identity in Medieval France

44 RITA COPELAND

Pedagogy, Intellectuals, and Dissent in the Later Middle Ages: Lollardy and Ideas of Learning

45 KANTIK GHOSH

The Wycliffite Heresy: Authority and the Interpretation of Texts

46 MARY C. ERLER

Women, Reading, and Piety in Late Medieval England

47 D. H. GREEN

The Beginnings of Medieval Romance: Fact and Fiction II5O-I220

48 J. A. BURROW

Gestures and Looks in Medieval Narrative 
49 ARDis BUTTERFIELD

Poetry and Music in Medieval France: From Jean Renart to Guillaume de Machaut

50 EMILY STEINER

Documentary Culture and the Making of Medieval English Literature

5I William E. BURGWINKLE

Sodomy, Masculinity, and Law in Medieval Literature

52 NICK HAVELY

Dante and the Franciscans: Poverty and the Papacy in the Commedia

53 SIEGFRIED WENZEL

Latin Sermon Collections from Later Medieval England

54 ANANYa Jahanara Kabir AND DEANNE Williams (eds.)

Postcolonial Approaches to the European Middle Ages: Translating

Cultures

55 MARK MILLER

Philosophical Chaucer: Love, Sex, and Agency in the Canterbury Tales

56 SIMON GILSON

Dante and Renaissance Florence

57 RALPH HANNA

London Literature, $\mathrm{I} 300-\mathrm{I} 380$

58 MAURA NOLAN

John Lydgate and the Making of Public Culture

59 NiCOLETTE ZEEMAN

Piers Plowman and the Medieval Discourse of Desire

60 ANTHONY BALE

The Jew in the Medieval Book: English Antisemitisms I350-I500

6I ROBERT J. MEYER-LEE

Poets and Power from Chaucer to Wyatt

62 ISABEL DAVIS

Writing Masculinity in the Later Middle Ages

63 JOHN M. FYLER

Language and the Declining World in Chaucer, Dante and Jean de Meun

64 MATTHEW GIANCARLO

Parliament and Literature in Late Medieval England

65 D. H. GREEN

Women Readers in the Middle Ages 
66 MARY DOVE

The First English Bible: The Text and Context of the Wycliffite Versions

67 JENNI NUTTALL

The Creation of Lancastrian Kingship: Literature, Language and Politics in Late Medieval England

68 Laura ashe

Fiction and History in England, I066-I200

69 J. A. BURROW

The Poetry of Praise

70 MARY CARRUTHERS

The Book of Memory: A Study of Memory in Medieval Culture (Second Edition)

7I ANDREW COLE

Literature and Heresy in the Age of Chaucer

72 SUZANNE M. YEAGER

Jerusalem in Medieval Narrative

73 NICOLE R. RICE

Lay Piety and Religious Discipline in Middle English Literature

74 D. H. GREEN

Women and Marriage in German Medieval Romance

75 PETER GODMAN

Paradoxes of Conscience in the High Middle Ages: Abelard, Heloise and the Archpoet

76 EDWIN D. CRAUN

Ethics and Power in Medieval English Reformist Writing

77 DAVID MATTHEWS

Writing to the King: Nation, Kingship, and Literature in England, I250-I350

78 MARY CARRUTHERS (ed.)

Rhetoric Beyond Words: Delight and Persuasion in the Arts of the Middle Ages

79 KATHARINE BREEN

Imagining an English Reading Public, II5O-I40O

8 o ANTONY J. HASLER

Court Poetry in Late Medieval England and Scotland: Allegories of Authority

8I SHANNON GAYK

Image, Text, and Religious Reform in Fifteenth-Century England

82 LISA H. COOPER

Artisans and Narrative Craft in Late-Medieval England 
83 ALISON CORNISH

Vernacular Translation in Dante's Italy: Illiterate Literature

84 JANE GILBERT

Living Death in Medieval French and English Literature

85 JESSICA ROSENFELD

Ethics and Enjoyment in Late Medieval Poetry: Love after Aristotle

86 MICHAEL VAN DUSSEN

From England to Bohemia: Heresy and Communication in the Later

Middle Ages

87 MARTIN EISNER

Boccaccio and the Invention of Italian Literature: Dante, Petrarch, Cavalcanti, and the Authority of the Vernacular

88 EMILY V. THORNBURY

Becoming a Poet in Anglo-Saxon England

89 LAWRENCE WARNER

The Myth of Piers Plowman: Constructing a Medieval Literary Archive 